\title{
An annotated catalogue of the scorpion types (Arachnida, Scorpiones) held in the Zoological Museum Hamburg. Part I: Parvorder Iurida Soleglad \& Fet, 2003
}

\author{
Lionel Monod ${ }^{1}$, Nadine Dupérré ${ }^{2}$, Danilo Harms ${ }^{2}$ \\ 1 Département des arthropods et d'entomologie I, Muséum d'histoire naturelle, Route de Malagnou 1, 1208 Geneva, Switzerland \\ 2 Zoological Museum, Center of Natural History, Universität Hamburg, Martin-Luther-King-Platz 3, Hamburg, Germany
}

http://zoobank.org/87602625-AF8D-4A3F-BAE5-F35C09FB6C00

Corresponding author: Lionel Monod (lionel.monod@ville.ge.ch)

Received 19 June 2019

Accepted 23 September 2019

Published 10 December 2019

Academic editor:

Martin Husemann

\section{Key Words}

arachnology

Karl Kraepelin

systematics

taxonomy

type catalogue

\begin{abstract}
Scorpions have always inspired fear and fascination because of the potency of their venoms. Although this ancient arachnid group is relatively small (ca. 2400 species) and has been continuously studied for the past century, the taxonomy is still in a state of flux and the correct identification of species often remains difficult. With more than 725 species and 9000 specimens, the Zoological Museum in Hamburg (ZMH) holds one of the largest and most significant scorpion collections in the world. This collection also contains many historical types described by Karl Kraepelin in the early $20^{\text {th }}$ century. In order to contribute to a more stable scorpion taxonomy and to assist future scorpion researchers, we present an illustrated and annotated catalogue of the $\mathrm{ZMH}$ scorpion collections. The type specimens of 89 species belonging to 10 families are documented, imaged and assessed alongside their primary data. For practical reasons, only the taxa belonging to the parvorder Iurida Soleglad et Fet, 2003 are presented here whilst the Parvorder Buthida Soleglad et Fet, 2003 will be catalogued in a second publication.
\end{abstract}

\section{Table of contents}

Introduction. 110

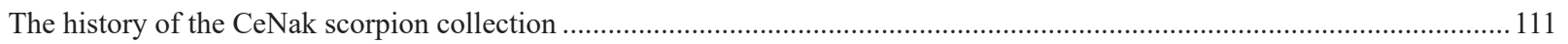

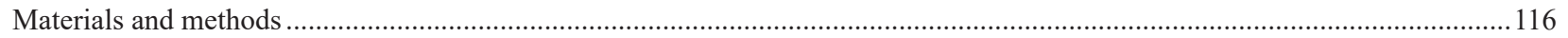

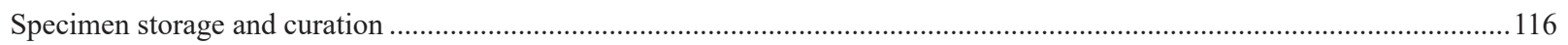

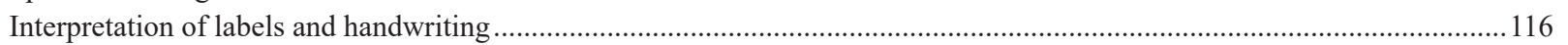

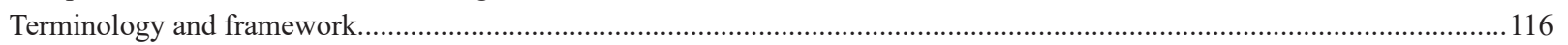

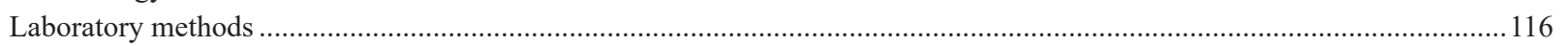

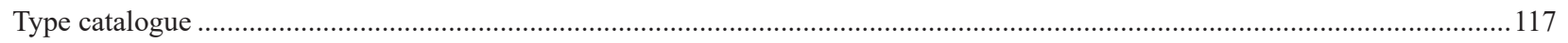

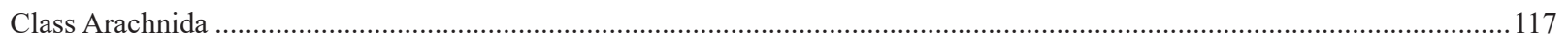

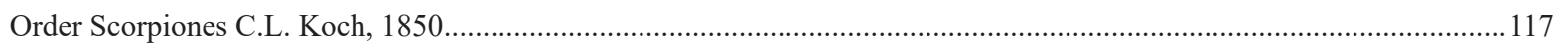

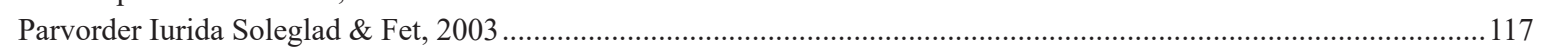

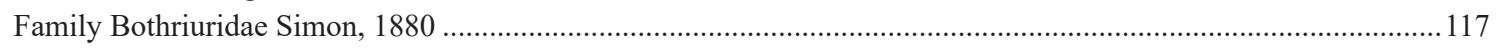

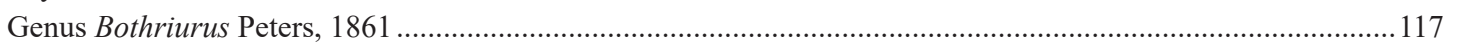

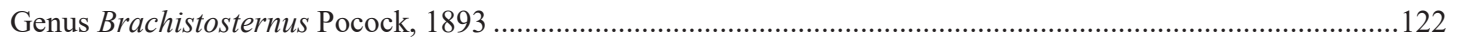

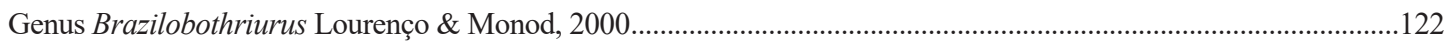

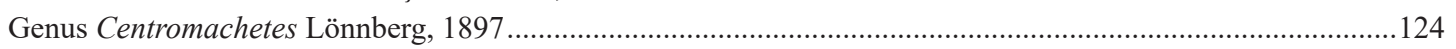


Genus Cercophonius Peters, 1861.

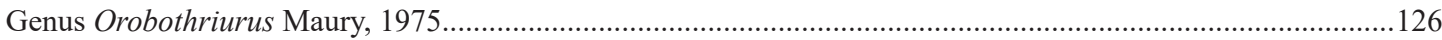

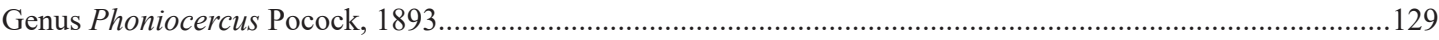

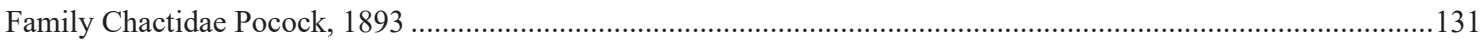

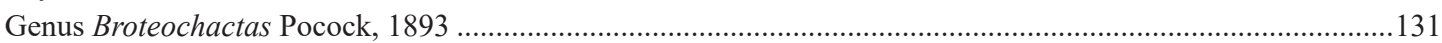

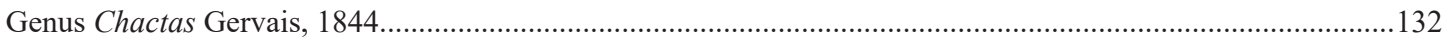

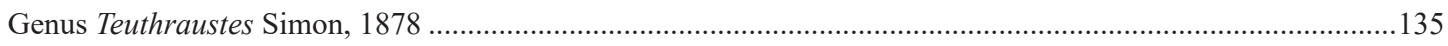

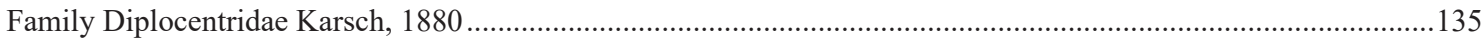

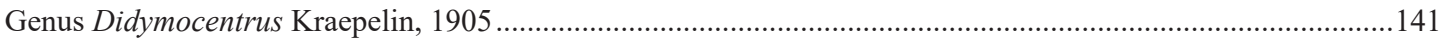

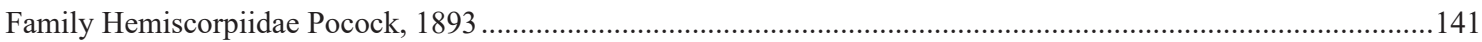

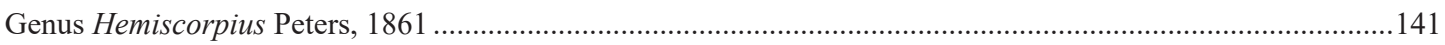

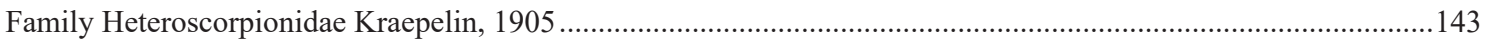

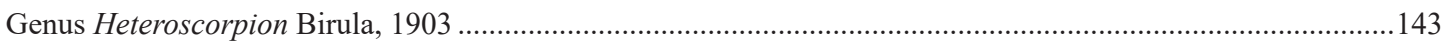

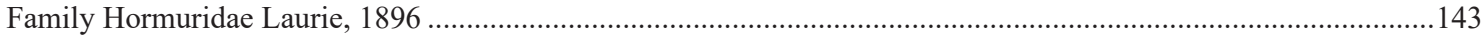

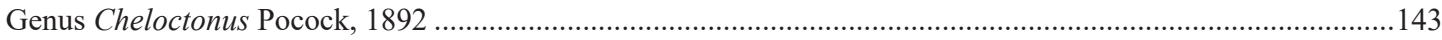

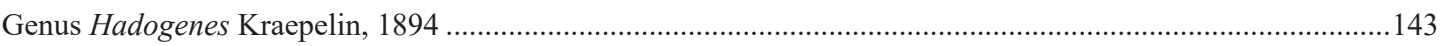

Genus Hormurus Thorell, 1876 ...............................................................................................................143

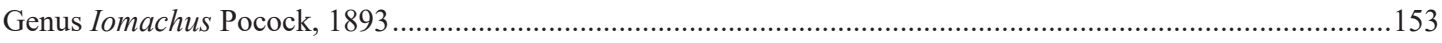

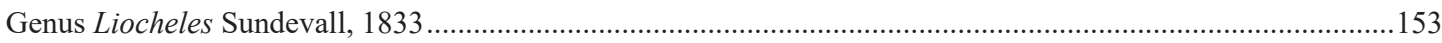

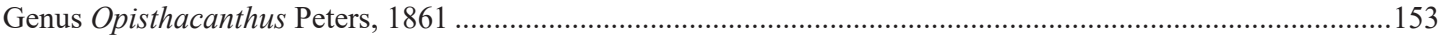

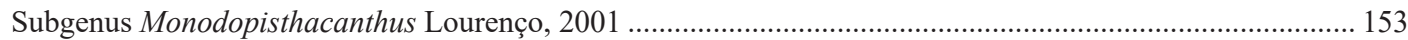

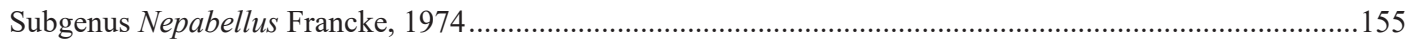

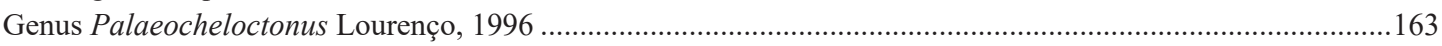

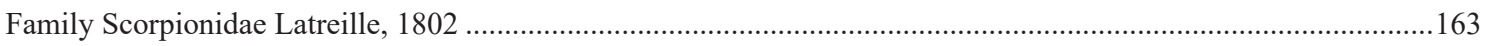

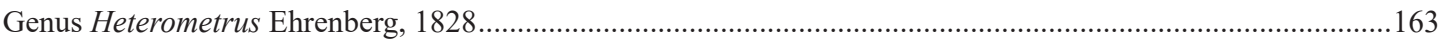

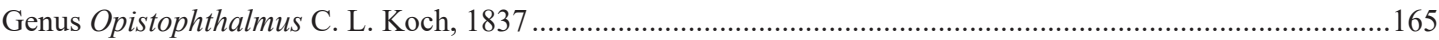

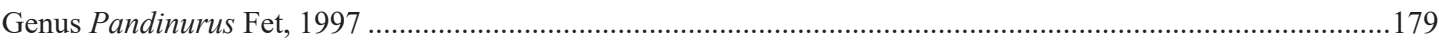

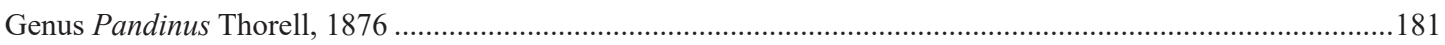

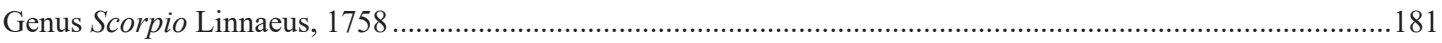

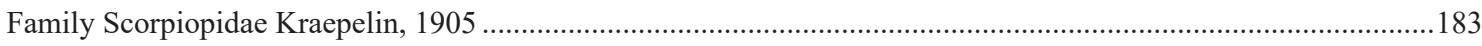

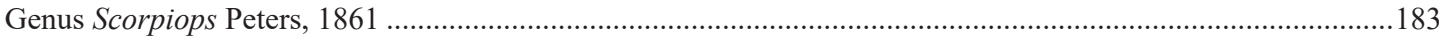

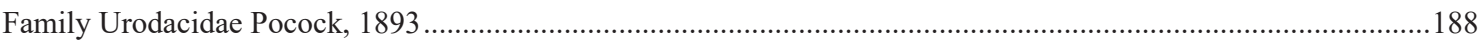

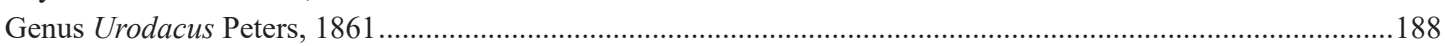

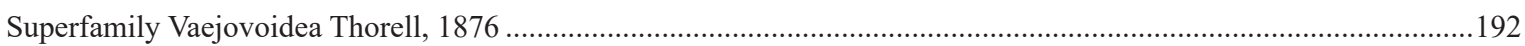

Genus Catalinia Soleglad, Ayrey, Graham \& Fet, 2017 _............................................................................192

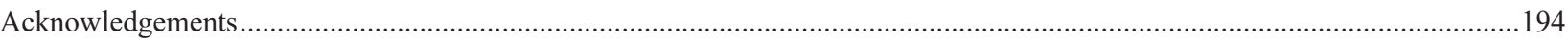

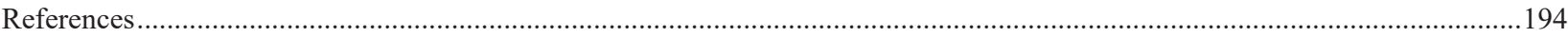

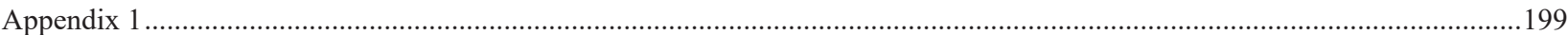

\section{Introduction}

The inventory of life on Earth is founded on taxonomy, the science of describing, naming and classifying species. Being able to correctly recognize an organism is a prerequisite to study the diversification of living forms through time. Taxonomy thus represents the primary tool used in the broader practice of systematics. Large reference collections of specimens are of paramount importance for both disciplines. They are required to confirm the status of new species by comparison with those that are already known, but also to infer species distributions, and to assess changes in species abundances and range shifts through time series (Habel et al. 2013). Such collections are principally held by natural history museums which today serve as libraries and infrastructure for biodiversity research. One of the most significant collections of scorpions is held by the Zoological Museum in Hamburg.
It comprises roughly 9000 specimens belonging to more than 725 species. It was accumulated over more than a century of research, includes specimens from all over the world, and is rich in type material.

A major problem with old collections such as the one treated here is the inadequacy of early taxonomic descriptions and accompanying data to fulfill current-day standards. The lack of proper illustrations and/or measurements often limits the usefulness of these descriptions and the original material needs to be re-examined and re-described by present-day authors as part of taxonomic revisions. Moreover, a century ago the principle of type designation had not yet been implemented and the original descriptions often lack critical information on which specimens of a given series were used as reference, as well as information on the origin and repository of these specimens. Finally, locality data for old museum specimens are often highly imprecise with minimal 
geographical information. Still, the maps produced at the time during major scientific expeditions were often quite accurate and can be georeferenced a posteriori allowing the assessment of locality data with high precision. However, such maps are not always available.

All problems highlighted above are evident when working with the scorpion material held by the Zoological Museum in Hamburg (ZMH, Germany). The core of this collection was accumulated by arachnologist Karl Kraepelin (1848-1915) who was one of the early leading scorpion specialists and probably one of the most influential. Kraepelin's landmark monograph in "Das Tierreich" (Kraepelin 1899a) was recognized for several decades as the most exhaustive classification of the order Scorpiones. Kraepelin's contribution to scorpion taxonomy is not limited to this work but also includes an important series of papers published between 1891 and 1929 that resulted in the description of many new taxa (see table 1) and the establishment of a large collection of types. This collection was never reassessed and documented in its entirety. Only a few of the original specimens have been re-examined and illustrated in the course of revisionary works (Kovařík 2009; Kovařík and Ojanguren Affilastro 2013) but these publications only treated specific taxa and did not provide a comprehensive overview of the complete collection.

Here, we provide an illustrated type catalogue of the scorpion collection present at the Zoological Museum in Hamburg. This work offers a complete inventory of the type species, type specimens within each series, high-resolution images for type specimens, and annotated notes on the primary data. A special effort was made to determine type localities with as much accuracy as possible by finding information on collectors or expeditions during which the material was obtained. This catalogue is aiming to stabilize the taxonomy in a group where species descriptions go back to Carl Linnaeus but current classification systems are still in flux. For reasons of manageability, our catalogue will be published in two parts. The current catalogue treats the taxa belonging to the parvorder Iurida Soleglad \& Fet 2003. A second publication will focus entirely on the Parvorder Buthida Soleglad \& Fet 2003.

\section{The history of the CeNak scorpion collection}

The core of the Hamburg scorpion collection was accumulated by Karl Matthias Friedrich Magnus Kraepelin (1848-1915; Karl Kraepelin hereafter; Fig. 1A) who was the director of the Hamburg Museum from 1889 to 1914 (see Harms and Dupérré 2018 for additional details). Kraepelin was a versatile naturalist and a productive scientist who not only authored teaching materials and nature guides for school students (Kraepelin 1918, 1921, 1926), but also works on a wide array of different topics in the field of biology, e.g. botany and identification guides for plants (Kraepelin 1913a, 1917, 1927), the role of natural history museums (Kraepelin 1891a, 1901a, 1912a), invasive species (Kraepelin 1901b), the local fau- na of Hamburg (Kraepelin 1886, 1896a, 1901c), and several groups of invertebrates such as bryozoans (Kraepelin 1887, 1892, 1914a), insects and their functional morphology (Kraepelin 1883, 1884), scolopendromorph centipedes (Kraepelin 1903a, 1908a, 1916), and some of the arachnid orders (Kraepelin 1897a, 1899b, 1901d, 1904, 1929).

Kraepelin's work was internationally recognized and he became an expert on Gliederspinnen ("Segmented spiders"), a general term then applied to scorpions (Scorpiones), whip scorpions (Uropygi), whip spiders (Amblypygi) and camel spiders (Solifugae). He published extensively on these groups and his most significant works are complete taxonomic inventories of these orders in "Scorpiones and Pedipalpi" (Kraepelin 1899a) (Fig. 2B) and "Palpigradi und Solifugae" (Kraepelin 1901d) in "Das Tierreich", a book series that provided a complete taxonomic inventory of all species on Earth known by then.

Kraepelin was particularly fond of scorpions and, aside from these monographs, published 25 research papers on this order (Table 1). In these works, he focused predominantly on taxonomy, but also studied scorpion biogeography (Kraepelin 1905) and sexual morphology (Kraepelin 1908b). As was common amongst taxonomists at that time, Kraepelin would frequently identify and describe the material collected during various zoological expeditions and his later papers are often published in large monographs that compile the zoological results of expeditions that departed from the port of Hamburg, predominately to Africa and Australia. His works on the morphology and biogeography of scorpions have largely been forgotten which may be due to their publication in German but they still contain useful information and demonstrate expertise beyond taxonomy.

Other workers have contributed to the development of this scorpion collection during the first third of the $20^{\text {th }}$ century. Kraepelin was in contact with fellow arachnologist Eugène Simon (1848-1924) from the Muséum national d'Histoire naturelle in Paris and the two exchanged material quite frequently. None of the original correspondence have been preserved and there is no documentation on when this exchange has occurred, but some type series of scorpions and spiders are split between Paris and Hamburg and it appears that Kraepelin would send spiders from the Hamburg collection to Simon for taxonomic description (Dupérré and Harms 2018) whereas Kraepelin catalogued the entire scorpion collection of the Paris museum (Kraepelin 1901e) and described species from this collection. It is interesting to note that Simon also described scorpions during the earlier stages of his career (Simon 1872, 1874, 1876, 1877a, 1877b, 1878a, $1878 \mathrm{~b}, 1879,1880 \mathrm{a}, 1880 \mathrm{~b}, 1885,1887)$ but not so after Kraepelin had catalogued all the Gliederspinnen (scorpions, solifuges, whip spiders and whip scorpions) from the Paris museum (Kraepelin 1899c, 1901e, 1901f).

Similarly, Ferdinand Karsch (1853-1936) from the Zoological Museum in Berlin and Kraepelin must have 
Table 1. The research papers published by Karl Krapelin on scorpions, the new species described within, and their current status. English translations for original research articles in German language are given in square brackets. Species in bold have been synonymised since their original description. * Species treated within this paper.

\begin{tabular}{|c|c|c|}
\hline Year / name of publication & Original species and page of description & \begin{tabular}{|l|} 
Valid species and current classification \\
\end{tabular} \\
\hline $\begin{array}{l}\text { 1891: Revision der Skorpione. I. Die Familie der } \\
\text { Androctonidae [Revision of scorpions. I. The } \\
\text { family Androctonidae] (Kraepelin, 1891b) }\end{array}$ & 1. Centrurus thorellii: p. 124 & 1. Centruroides thorellii (Kraepelin, 1891) \\
\hline $\begin{array}{l}\text { 1894: Revision der Scorpione. II. Scorpionidae } \\
\text { und Bothriuridae [Revision of scorpions. II. } \\
\text { Scorpionidae und Bothriuridae] (Kraepelin, 1894) }\end{array}$ & $\begin{array}{l}\text { 1. Scorpio arabicus: p. } 58 . \\
\text { 2. Scorpio pallidus*: p. } 60 \text {. } \\
\text { 3. Opisthophthalmus intermedius } * \text { : p. } 89 \\
\text { 4. Opisthophthalmus pictus*: p. } 102 \\
\text { 5. Opistacanthus madagascariensis } * \text { : p. } 125 \\
\text { 6. Bothriurus burmeisteri*: p. } 227\end{array}$ & $\begin{array}{l}\text { 1. Pandiborellius arabicus (Kraepelin, 1894)* } \\
\text { 2. Pandinurus pallidus (Kraepelin, 1894)* } \\
\text { 3. Opistophthalmus intermedius Kraepelin, 1894* } \\
\text { 4. Opistophthalmus pictus Kraepelin, 1894* } \\
\text { 5. Opisthacanthus madagascariensis Kraepelin, 1894* } \\
\text { 6. Bothriurus burmeisteri Kraepelin, 1894* }\end{array}$ \\
\hline $\begin{array}{l}\text { 1895: Nachtrag zu Theil I der Revision der } \\
\text { Scorpione [Supplement to Part I of the revision of } \\
\text { scorpions] (Kraepelin, 1895a) }\end{array}$ & $\begin{array}{l}\text { 1. Tityus paraguayensis: p. } 19 \\
\text { 2. Tityus bolivianus: p. } 21\end{array}$ & $\begin{array}{l}\text { 1. Tityus paraguayensis Kraepelin, } 1895^{*} \\
\text { 2. Tityus bolivianus Kraepelin, } 1895^{*}\end{array}$ \\
\hline $\begin{array}{l}\text { 1896: Neue und weniger bekannte Skorpione } \\
\text { [New and less well-known scorpions] (Kraepelin, } \\
\text { 1896b) }\end{array}$ & 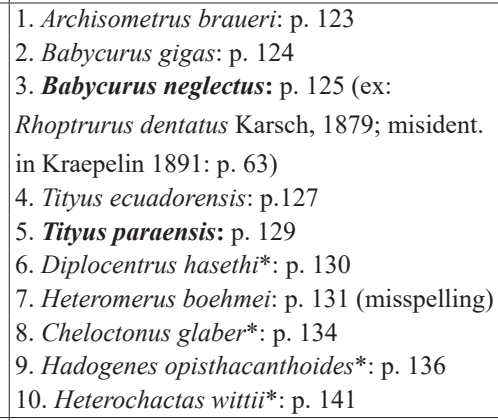 & $\begin{array}{l}\text { 1. Lychas braueri (Kraepelin, 1896) } \\
\text { 2. Babycurus gigas Kraepelin, 1896 } \\
\text { 3. Babycurus kirki (Pocock, 1890) } \\
\text { 4. Tityus ecuadorensis Kraepelin, } 1896 \\
\text { 5. Tityus obscurus (Gervais, 1843) } \\
\text { 6. Didymocentrus hasethi (Kraepelin, 1896)* } \\
\text { 7. Opistophthalmus boehmi (Kraepelin, 1896) } \\
\text { 8. Cheloctonus glaber Kraepelin, 1896* } \\
\text { 9. Heteroscorpion opisthacanthoides (Kraepelin, 1896)* } \\
\text { 10. Teuthraustes wittii (Kraepelin, 1896)* }\end{array}$ \\
\hline $\begin{array}{l}\text { 1897: Scorpiones und Thelyphoniden [Scorpiones } \\
\text { and Thelyphonida] (Kraepelin, 1897b) }\end{array}$ & No new species. & - \\
\hline $\begin{array}{l}\text { 1898: Neue Pedipalpen und Skorpione des } \\
\text { Hamburger Museums [New Pedipalpi and } \\
\text { scorpions of the Hamburg Museum] (Kraepelin, } \\
\text { 1898a) }\end{array}$ & $\begin{array}{l}\text { 1. Microbuthus pusillus: p. } 42 \\
\text { 2. Butheolus ferrugineus: p. } 43 \\
\text { 3. Archisometrus nigrimanus: p. } 43 \\
\text { 4. Tityus trivittatus: p. } 43 \\
\text { 5. Centrurus subgranosus: p. } 44 \\
\text { 6. Scorpiops affinis*: p. } 44\end{array}$ & $\begin{array}{l}\text { 1. Microbuthus pusillus Kraepelin, } 1898 \\
\text { 2. Neobuthus ferrugineus (Kraepelin, 1908) } \\
\text { 3. Lychas scutilus C. L. Koch, } 1845 \\
\text { 4. Tityus trivittatus Kraepelin, } 1898 \\
\text { 5. Centruroides vittatus (Say, 1821) } \\
\text { 6. Scorpiops hardwickii (Gervais, 1843)* } \\
\end{array}$ \\
\hline $\begin{array}{l}\text { 1898: Die Skorpione Ost-Afrikas [The scorpions } \\
\text { of eastern Africa] (Kraepelin, 1898b) }\end{array}$ & No new species. & - \\
\hline $\begin{array}{l}\text { 1898: Über die Linné'schen Arten der Gattung } \\
\text { Scorpio [About the Linnaean species of the genus } \\
\text { Scorpio] (Kraepelin, 1898c) }\end{array}$ & No new species. & - \\
\hline $\begin{array}{l}\text { 1899: Scorpiones und Pedipalpi [Scorpiones and } \\
\text { Pedipalpi] (Kraepelin, 1899a) }\end{array}$ & No new species. & - \\
\hline $\begin{array}{l}\text { 1900: Ueber einige neue Gliederspinnen [Remarks } \\
\text { on some new segmented spiders] (Kraepelin, } \\
\text { 1900) }\end{array}$ & $\begin{array}{l}\text { 1. Anomalobuthus rickmersi: p. } 10 \\
\text { 2. Buthus maindroni: p. } 11 \\
\text { 3. Grosphus grandidieri: } \text { p. } 13 \\
\text { 4. Grosphus flavopiceus: } \text {. } 14 \\
\text { 5. Grosphus bistriatus: } \text { p. } 14 \\
\text { 6. Grosphus hirtus: } \text { p. } 15 \\
\text { 7. Hemiscorpius maindroni*: p. } 16 \\
\text { 8. Syntropis macrura: } \text { p. } 17\end{array}$ & $\begin{array}{l}\text { 1. Anomalobuthus rickmersi Kraepelin, 1900 } \\
\text { 2. Compsobuthus maindroni (Kraepelin, 1900) } \\
\text { 3. Teruelius grandidieri (Kraepelin, 1900) } \\
\text { 4. Teruelius flavopiceus (Kraepelin, 1900) } \\
\text { 5. Teruelius bistriatus (Kraepelin, 1900) } \\
\text { 6. Grosphus hirtus Kraepelin, 1900 } \\
\text { 7. Hemiscorpius maindroni Kraepelin, 1900* } \\
\text { 8. Syntropis macrura Kraepelin, } 1900\end{array}$ \\
\hline $\begin{array}{l}\text { 1901: Catalogue des scorpions des collections du } \\
\text { Muséum d'Histoire Naturelle de Paris [Catalogue } \\
\text { of the scorpions from the Muséum d'Histoire } \\
\text { Naturelle de Paris] (Kraepelin, 1901e) }\end{array}$ & No new species. & - \\
\hline $\begin{array}{l}\text { 1901: Uber die durch den Schiffsverkehr in } \\
\text { Hamburg eingeschleppten Tiere [About animals } \\
\text { introduced by the shipping traffic in Hamburg] } \\
\text { (Kraepelin, 1901b) }\end{array}$ & No new species. & - \\
\hline $\begin{array}{l}\text { 1903: Scorpione und Solifugen Nordost-Afrikas, } \\
\text { gesammelt } 1900 \text { und } 1901 \text { von Carlo Freiherrn } \\
\text { von Erlanger und Oscar Neumann [Scorpions and } \\
\text { solifuges from northeastern Africa, collected in } \\
1900 \text { and } 1901 \text { by Carlo Freiherr von Erlanger and } \\
\text { Oscar Neumann] (Kraepelin, 1903b) }\end{array}$ & 1. Butheolus glabrifrons: p. 564 & 1. Orthochirus glabrifrons Kraepelin, 1903 \\
\hline $\begin{array}{l}\text { 1904: Zur Nomenklatur der Skorpione und } \\
\text { Pedipalpi [On the nomenclature of scorpions and } \\
\text { Pedipalpi] (Kraepelin, 1904) }\end{array}$ & No new species. & - \\
\hline
\end{tabular}




\begin{tabular}{|c|c|c|}
\hline Year / name of publication & Original species and page of description & Valid species and current classification \\
\hline $\begin{array}{l}\text { 1905: Die geografische Verbreitung der Skorpione } \\
\text { [The geographical distribution of scorpions] } \\
\text { (Kraepelin, 1905) }\end{array}$ & No new species. & - \\
\hline 1908: Scorpiones [Scorpiones] (Kraepelin, 1908c) & $\begin{array}{l}\text { 1. Urodacus hartmeyeri*: p. } 99 \\
\text { 2. Cercophonius michaelseni*: p. } 102 \\
\text { 3. Cercophonius granulosus*: p. } 103 \\
\text { 4. Cercophonius sulcatus*: p. } 103\end{array}$ & $\begin{array}{l}\text { 1. Urodacus hartmeyeri Kraepelin, 1908* } \\
\text { 2. Cercophonius michaelseni Kraepelin, 1908* } \\
\text { 3. Cercophonius granulosus Kraepelin, 1908* } \\
\text { 4. Cercophonius sulcatus Kraepelin, 1908* }\end{array}$ \\
\hline $\begin{array}{l}\text { 1908: Skorpione und Solifugen [Scorpions and } \\
\text { solifuges] (Kraepelin, 1908d) }\end{array}$ & $\begin{array}{l}\text { 1. Uroplectes carinatus mediostriatus: p. } 257 \\
\text { 2. Opisthophthalmus schultzei*: p. } 262 \\
\text { 3. Opisthophthalmus undulatus*: p. } 263 \\
\text { 4. Opisthophthalmus intercedens*: p. } 265\end{array}$ & $\begin{array}{l}\text { 1. Uroplectes carinatus (Pocock, 1890) } \\
\text { 2. Opistophthalmus schultzei Kraepelin, 1908* } \\
\text { 3. Opistophthalmus schultzei Kraepelin, 1908* } \\
\text { 4. Opistophthalmus intercedens Kraepelin, 1908* }\end{array}$ \\
\hline $\begin{array}{l}\text { 1908: Die sekundären Geschlechtscharaktere } \\
\text { der Skorpione, Pedipalpen und Solifugen [The } \\
\text { secondary sexual characters of scorpions, } \\
\text { pedipalpi and solifuges] (Kraepelin, 1908b) }\end{array}$ & No new species. & - \\
\hline $\begin{array}{l}\text { 1911: Neue Beiträge zur Systematik der } \\
\text { Gliederspinnen [New contributions to the } \\
\text { systematics of segmented spiders] (Kraepelin, } \\
\text { 1911) }\end{array}$ & $\begin{array}{l}\text { 1. Tityus bocki: p. } 65 \\
\text { 2. Tityus bolivianus andinus: p. } 66 \\
\text { 3. Tityus bolivianus soratensis: p. } 68 \\
\text { 4. Centruoides koesteri: p. } 72 \\
\text { 5. Opisthacanthus fischeri*: p. } 79 \\
\text { 6. Opisthacanthus minor*: p. } 79 \\
\text { 7. Opisthacanthus aequispinus*: p. } 80 \\
\text { 8. Opisthacanthus obscurus*: p. } 81 \\
\text { 9. Opisthacanthus transvaalicus*: p. } 82 \\
\text { 10. Vejovis minimus*: p. } 83 \\
\text { 11. Bothriurus flavidus*: p. } 92 \\
\text { 12. Bothriurus bocki*: p. } 96 \\
\text { 13. Bothriurus curvidigitus*: p. } 97 \\
\text { 14. Bothriurus paessleri*: p. } 98 \\
\end{array}$ & $\begin{array}{l}\text { 1. Tityus argentinus } \text { Borelli, } 1899 \\
\text { 2. Tityus argentinus Borelli, } 1899 \\
\text { 3. Tityus soratensis Kraepelin, } 1911 \\
\text { 4. Centruoides koesteri Kraepelin, } 1911 \\
\text { 5. Opisthacanthus rugiceps Pocock, } 1897 \\
\text { 6. Opisthacanthus validus Thorell, } 1876 \\
\text { 7. Opisthacanthus diremptus (Karsch, 1879) } \\
\text { 8. Opisthacanthus capensis Thorell, } 1876 \\
\text { 9. Opisthacanthus validus Thorell, } 1876 \\
\text { 10. Catalinia minima (Kraepelin, 1911)* } \\
\text { 11. Bothriurus flavidus Kraepelin, 1911* } \\
\text { 12. Bothriurus bocki Kraepelin, } 1911^{*} \\
\text { 13. Orobothriurus curvidigitus (Kraepelin, 1911)* } \\
\text { 14. Orobothriurus paessleri (Kraepelin, 1911)* }\end{array}$ \\
\hline $\begin{array}{l}\text { 1912: Neue Beiträge zur Systematik der } \\
\text { Gliederspinnen. II. Chactinae (Scorpiones) [New } \\
\text { contributions to the systematics of segmented } \\
\text { spiders. II. Chactinae (Scorpiones)] (Kraepelin, } \\
\text { 1912b) }\end{array}$ & $\begin{array}{l}\text { 1. Chactas setosus*: p. } 62 \\
\text { 2. Chactas gestroi: } \text { p. } 69 \\
\text { 3. Teuthraustes ohausi } * \text { : p. } 77 \\
\text { 4. Teuthraustes glaber: p. } 80 \\
\text { 5. Chactopsis insignis: p. } 87\end{array}$ & $\begin{array}{l}\text { 1. Chactas setosus Kraepelin, } 1912^{*} \\
\text { 2. Chactas gestroi Kraepelin, } 1912 \\
\text { 3. Teuthraustes ohausi Kraepelin, } 1912^{*} \\
\text { 4. Teuthraustes glaber Kraepelin, 1912* } \\
\text { 5. Chactopsis insignis Kraepelin, } 1912\end{array}$ \\
\hline $\begin{array}{l}\text { 1913: Neue Beiträge zur Systematik der } \\
\text { Gliederspinnen. III. A. Bemerkungen zur } \\
\text { Skorpionenfauna Indiens. B. Die Skorpione, } \\
\text { Pedipalpen und Solifugen Deutsch-Ostafrikas } \\
\text { [New contributions to the systematics of } \\
\text { segmented spiders. III. The scorpions, Pedipalpi } \\
\text { and solifuges of German East Africa.] (Kraepelin, } \\
\text { 1913b) }\end{array}$ & $\begin{array}{l}\text { 1. Chaerilus assamensis: p. } 144 \\
\text { 2. Chaerilus granifrons: p. } 147 \\
\text { 3. Chaerilus hirsti: p. } 150 \\
\text { 4. Lychas obsti: } \text { p. } 175 \\
\text { 5. Lychas asper var. obscurus: } \text { p. } 175 \\
\text { 6. Uroplectes fischeri nigrocarinatus: } \text { p. } 179 \\
\text { 7. Babycurus wituensis: } \text { p. } 181\end{array}$ & $\begin{array}{l}\text { 1. Chaerilus assamensis Kraepelin, } 1913 \\
\text { 2. Chaerilus truncatus Karsch, } 1879 \\
\text { 3. Chaerilus truncatus Karsch, } 1879 \\
\text { 4. Lychas obsti Kraepelin, } 1913 \\
\text { 5. Lychas asper (Pocock, 1891) } \\
\text { 6. Uroplectes fischeri nigrocarinatus Kraepelin, } 1913 \\
\text { 7. Babycurus wituensis Kraepelin, } 1913\end{array}$ \\
\hline $\begin{array}{l}\text { 1914: Skorpione und Solifugae [Scorpions and } \\
\text { solifuges] (Kraepelin, 1914b) }\end{array}$ & No new species. & - \\
\hline $\begin{array}{l}\text { 1914: Beiträge zur Kenntnis der Skorpione } \\
\text { und Pedipalpen Columbiens [Contributions to } \\
\text { the knowledge of scorpions and Pedipalpi in } \\
\text { Colombia] (Kraepelin, 1914c) }\end{array}$ & $\begin{array}{l}\text { 1. Tityus fuhrmanni: } \text { p. } 17 \\
\text { 2. Tityus parvulus: p. } 19 \\
\text { 3. Chactas reticulatus: } \text { p. } 25\end{array}$ & $\begin{array}{l}\text { 1. Tityus fuehrmanni } \text { Kraepelin, } 1914 \\
\text { 2. Tityus parvulus: Kraepelin, } 1914 \\
\text { 3. Chactas reticulatus: Kraepelin, } 1914 \text { * }\end{array}$ \\
\hline $\begin{array}{l}\text { 1914: Die Skorpione und Pedipalpen von Neu- } \\
\text { Caledonien und den benachbarten Inselgruppen } \\
\text { [The scorpions and Pedipalpi of New Caledonia } \\
\text { and adjacent islands] (Kraepelin, 1914d) }\end{array}$ & $\begin{array}{l}\text { 1. Hormurus karschi keyensis*: } 331 \\
\text { 2. Hormurus sarasini*: p. } 335 \\
\text { 3. Hormurus papuanus*: p. } 333 \\
\text { 4. Hormurus boholiensis*: p. } 333\end{array}$ & $\begin{array}{l}\text { 1. Hormurus karschii Keyserling, } 1885 \\
\text { 2. Hormurus neocaledonicus Simon, } 1877 \\
\text { 3. Hormurus papuanus Kraepelin, } 1914 \\
\text { 4. Hormurus boholiensis Kraepelin, 1914* }\end{array}$ \\
\hline $\begin{array}{l}\text { 1916: Scolopendriden und Skorpione } \\
\text { [Scolopenders and scorpions] (Kraepelin, 1916) }\end{array}$ & $\begin{array}{l}\text { 1. Lychas mjobergi: p. } 25 \text { (note spelling as } \\
\text { mjöbergi }=\text { oe) } \\
\text { 2. Lychas marmoreus obscurus: p. } 27 \\
\text { 3. Lychas marmoreus nigrescens: p. } 27 \\
\text { 4. Lychas marmoreus kimberleyanus: p. } 28 \\
\text { 5. Lychas marmoreus splendens: } \text { p. } 28 \\
\text { 6. Lychas spinatus: p. } 33 \\
\text { 7. Urodacus fossor*: p. } 36 \\
\text { 8. Urodacus granifrons*: p. } 39\end{array}$ & $\begin{array}{l}\text { 1. Lychas mjobergi Kraepelin, } 1916 \\
\text { 2. Lychas marmoreus (C. L. Koch, 1844) } \\
\text { 3. Lychas marmoreus (C. L. Koch, 1844) } \\
\text { 4. Lychas variatus (Thorell, 1876) } \\
\text { 5. Lychas marmoreus (C. L. Koch, 1844) } \\
\text { 6. Lychas variatus (Thorell, 1876) } \\
\text { 7. Urodacus yaschenkoi (Birula, 1903) } \\
\text { 8. Urodacus yaschenkoi (Birula, 1903) }\end{array}$ \\
\hline $\begin{array}{l}\text { 1929: Skorpione, Pedipalpen und Solifugen der } \\
\text { zweiten Deutschen Zentral-Afrika-Expedition } \\
\text { 1910-1911 [Scorpions, Pedipalpi and solifuges of } \\
\text { the second German expedition to central Africa } \\
\text { 1910-1911] (Kraepelin, 1929) }\end{array}$ & 1. Uroplectes schubotzi: p. 89 & 1. Uroplectes schubotzi Kraepelin, 1929 \\
\hline
\end{tabular}




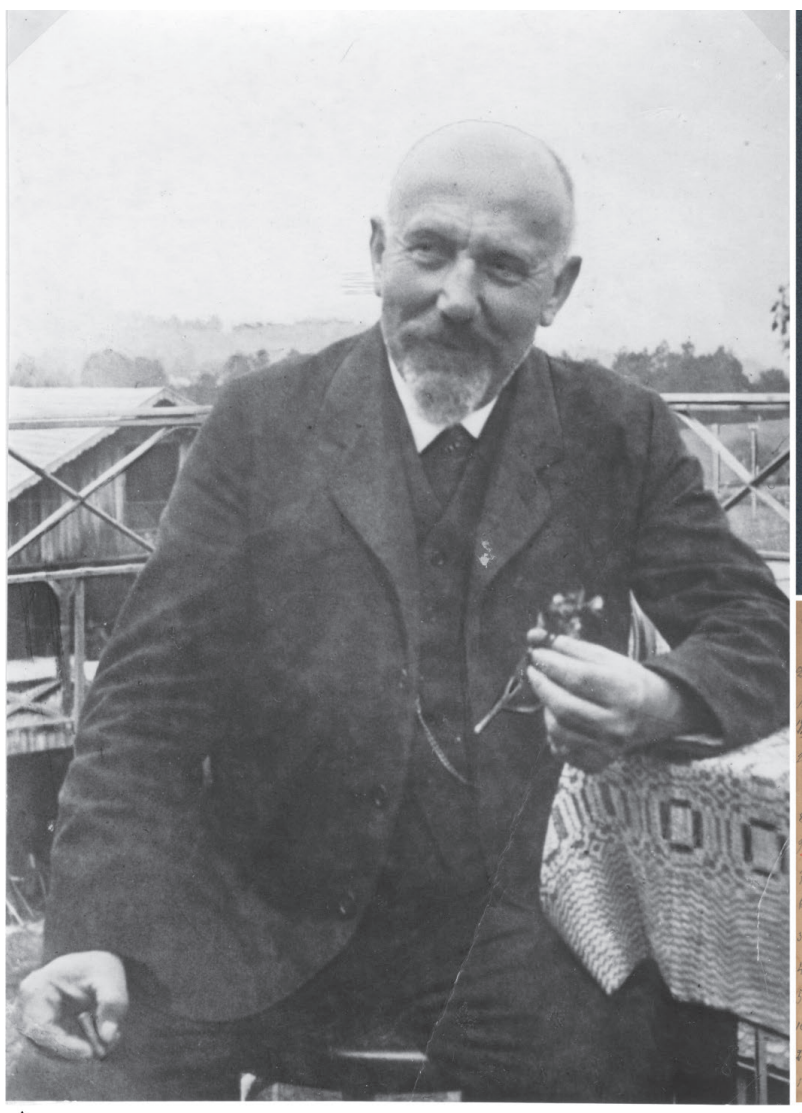

A

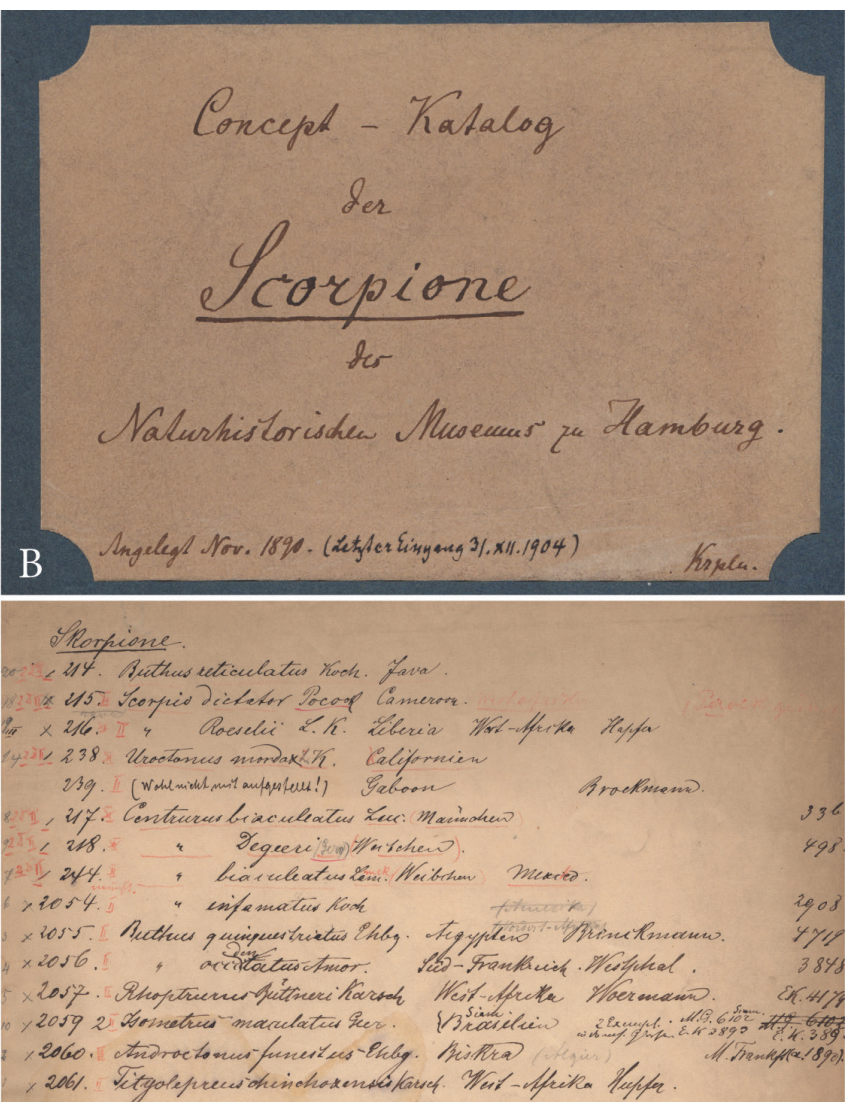

C

Figure 1. Karl Kraepelin and his works A portrait of Kraepelin B title page of the ZMH scorpion catalogue that was hand-written by Kraepelin $\mathbf{C}$ example of original handwriting in the catalogue.

exchanged material, as we have documented before in a catalogue on the solifuges of the Hamburg collection (Harms and Dupérré 2018). Kraepelin seemed to maintain cordial relations with several other naturalists from which he received specimens: Wilhelm Peters (18151883) from the Zoological Museum in Berlin, Reginald Innes Pocock (1863-1947) from the British Museum (London) and John Hewitt (1880-1961) from the Albany Museum (Grahamstown, South Africa). The lively exchange of specimens ended abruptly with the death of Kraepelin and a long hiatus occurred when the Zoological Museum in Hamburg was destroyed in World War II. Fortunately, the scorpion collections where hidden away in underground shafts and withstood the destruction of Hamburg in 1943. It is surprising that even the original type catalogue, handwritten by Kraepelin, remained intact and still provides useful data today.

Work on the scorpion collections after World War II was slow to resume because subsequent curators focused on mites and tardigrades but the collection was frequented by visiting scientists and many loans to other institutions occurred over the decades. Wilson R. Lourenço from the Muséum national d'Histoire naturelle in Paris described twelve new species from the existing collections but also donated several type specimens that he acquired personally. František Kovařík from the Czech Republic inventoried the entire collection and examined some old type specimens as part of his catalogues (Kovařík 2009; Kovařík and Ojanguren Affilastro 2013). He also deposited several type specimens in the $\mathrm{ZMH}$.

In its current state, the collection has a biogeographical focus on the African and Australasian regions. The specimens from Africa were collected mostly as part of zoological surveys in former German colonies, e.g. Carlo Freiherr von Erlangen (1872-1904) and Oscar Neumann (1867-1946) explored northeastern Africa from 1899 to 1901 (the former "Massailand" between northern Tanzania and southern Kenya), and Leonhard Schulze (1872-1955) visited "Namaland" (today part of Namibia) in southwestern Africa from 1903 to 1905. Several other large expeditions contributed to increase the scorpion collection of the ZMH. Wilhelm Michaelsen (1860-1937) led three expeditions to South America (1892-1893), southwestern Australia (1905) and southwestern Africa (1911) that added specimens to the collections. Eric Mjöberg (1882-1938) led the first Swedish scientific journey to Australia in 1910-1913. Otto Fuhrmann and his party visited Colombia in 1910 and Fritz Sarasin and Jean Roux travelled to New Caledonia and the Loyalty Islands in 1910-1912. When available, further information (biography, travel itinerary, references) are given about each collector and expeditions under the relevant individual species section. 

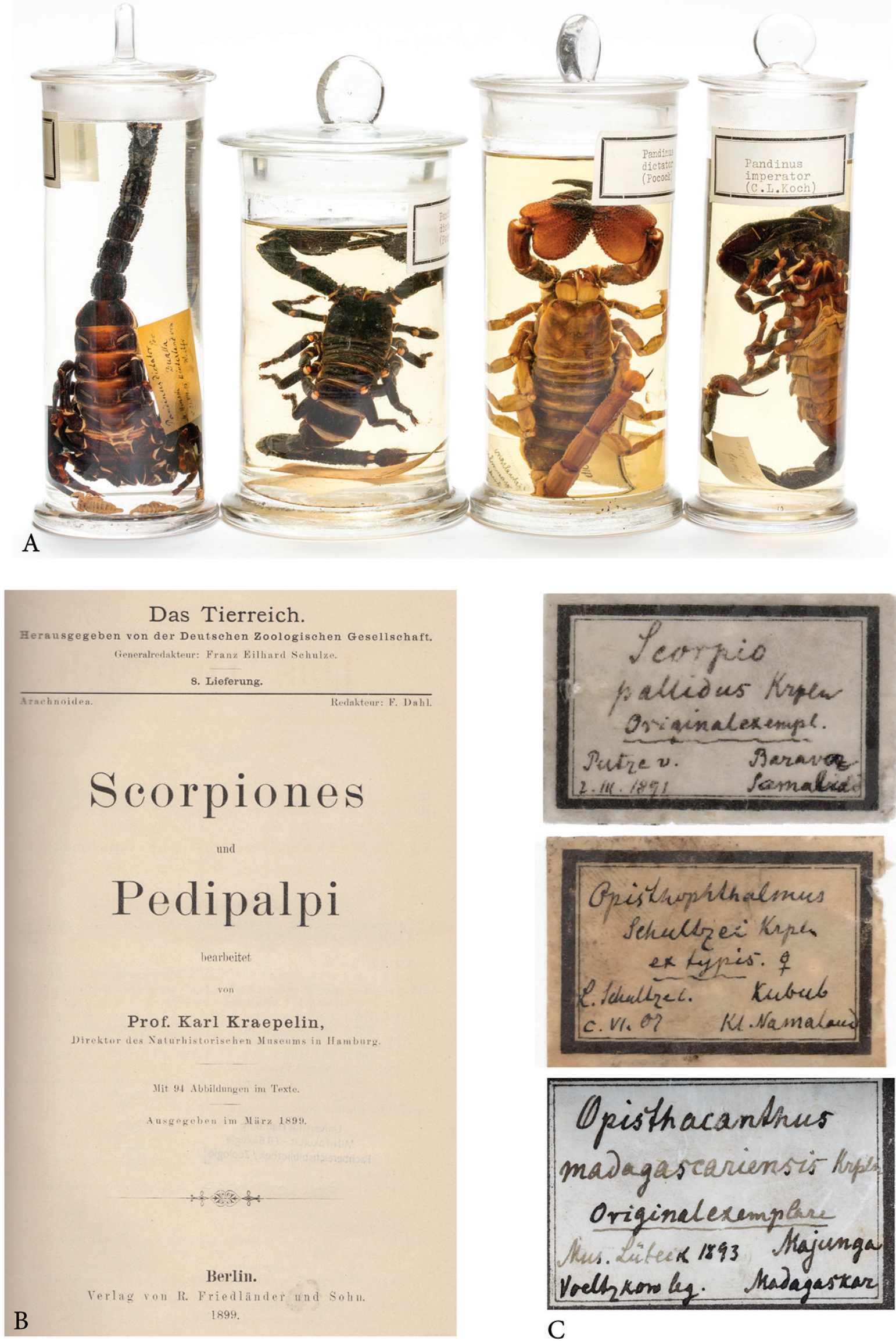

C

Figure 2. A Glass jars used for preservation of the scorpion specimens B title page of Kraepelin's "Scorpiones und Pedipalpi" in the "Das Tierreich" series $\mathbf{C}$ labels from the scorpion collection showing the typical handwriting of Kraepelin. 


\section{Materials and methods}

\section{Specimen storage and curation}

All specimens at ZMH are stored in jars with $75 \%$ ethanol (Fig. 2A) and dissected parts such as the hemispermatophores are kept in microvials together with the accompanying specimens to avoid misplacement. A new registration code for the $\mathrm{ZMH}$ specimens is introduced here which replaces previous labelling or replacement systems but we have given historical numbers and accompanying information below to allow referencing with old papers and the type catalogues by Fet et al. (2000), Kovař́ik (2009) and Kovařík and Ojanguren Affilastro (2013). The type series of a species may be split across several museums and relevant material is held in the following institutions: AMGS = Albany Museum, Grahamstown (South Africa); $\mathbf{B M N H}=$ Natural History Museum [formerly British Museum (Natural History)], London (United Kingdom); FKCP $=$ František Kovařík personal collection, Praha (Czech Republic); $\mathbf{M B C Z}=$ Matt E. Braunwalder personal collection, Zürich (Switzerland); $\mathbf{M C S N}=$ Museo Civico di Storia Naturale «Giacomo Doria», Genova (Italy); MHNG = Muséum d'histoire naturelle, Geneva (Switzerland); $\mathbf{M N H N}=$ Muséum National d'Histoire Naturelle, Paris (France); MNRJ = Universidade Federal de Rio de Janeiro, Museu Nacional do Rio de Janeiro (Brazil); MZUF = Museo Zoologico de "La Specola", Firenze (Italy); NMPC = National Museum, Praha (Czech Republic); $\mathbf{R O C C}=$ Rolando Teruel Ochoa personal collection, Museo de Historia Natural "Tomas Romay", Santiago de Cuba (Cuba); SAMC = South African Museum, Cape Town, South Africa; SMFD = Forschungsinstitut und Naturmuseum Senckenberg, Frankfurt am Main (Germany); ZMB = Museum für Naturkunde Berlin [Zoological Museum] (Germany); ZMH = Zoological Museum Hamburg (Germany); ZMUC = Natural History Museum of Denmark, Copenhagen (Denmark); ZSM = Zoological State Collection, Munich (Germany).

\section{Interpretation of labels and handwriting}

The primary data for most specimens were derived from the original label and a handwritten type-catalogue for scorpions maintained by Kraepelin (Fig. 1B). Kraepelin's style of writing is unique and the labels written by him can easily be identified (Figs 1C, 2C; see Harms and Dupérré 2018). Additional information is derived from card files that are available for the specimens in the museum archives.

\section{Terminology and framework}

There is currently no online catalogue for scorpions that is updated periodically and we refer to Fet et al. (2000) as a work basis and complement this work with data available from personal bibliographies and libraries. The definition of holotype, syntype, neotype and lectotype follows the Inter- national Code for Zoological Nomenclature (ICZN) and Articles 73-74 were applied when determining holotype status or designating a lectotype or paralectotypes. In cases where type status had to be inferred a posteriori, we followed a set of criteria that we have outlined in a previous catalogue on the ZMH solifuges (Harms and Dupérré 2018).

The catalogue is organized according to the classification proposed by Santibañez López et al. (2019) with the family Heteroscorpionidae considered here as part of Iurida given their close relationship to non-bothriurid scorpionoid taxa. Families, genera and species are presented alphabetically. Species are listed with their complete original binomial name, and classify under the genus in which they are currently placed. All specimens previously considered as types were re-examined for this study and their status clarified. In a few cases, type status was invalidated but such specimens are still reported here and our decision justified. Finally, a complete alphabetical list of taxon names (species and subspecies) is given in Appendix 1 and may be used for quick searches (current taxonomical status is provided for each name).

For every taxon name, the following information is provided: (1) the genus under which the species was originally described; (2) the reference of the original description; (3) the current taxonomic identity with reference to the act of synonymy or taxonomic status change when applicable; and (4) the list of specimens with primary data (type status of specimens, number and sex of specimens, depository, locality, date of collection, name of collector) in the original wording whilst interpretations/translations are given in square brackets (e.g. Type locality: Namibien, Lüderitzbucht [Namibia, Lüderitz Bay]). When not provided in the original labels, GPS coordinates are presented in square brackets. In these cases, they were retrieved from gazeteers of geographic names or inferred from the original travel maps when available. They are not provided for imprecise localities: for several specimens the only indication on the labels is the country they come from (for instance Bothriurus burmeisteri from Argentina). Additional information may be provided concerning taxonomy, repository, and/or type status. Finally, biographical information about the collector with references to their relevant expeditions is also provided when available.

The following abbreviations are used in the listing of primary data: (1) "coll." for collection or collected; "ded." for the latin deditus (participle of dedere [to hand over]), it specifies when a specimen was acquired; "don." for the latin donat (conjugation of donare [to give], third person singular), it specifies a donator; "leg." for the latin legit (conjugation of legere [to collect], third person singular), it specifies a collector.

\section{Laboratory methods}

Specimen imaging was achieved using a custom-made BK Plus lab System by Dun, Inc. with integrated Canon camera, macro lens $(65 \mathrm{~mm}$ and $100 \mathrm{~mm})$ and the Zerene stacking software (Zeren Systems LLC 2018). Whenev- 
er possible, the dorsal and ventral aspects of male and female habitus are illustrated. We also provide photographs of the chelal fingers for the family Hormuridae, Scorpiopidae and some chactid genera because the intergeneric and interspecific variations of the characters are taxonomically relevant, at least in parts of these families (Monod and Volschenk 2004; Monod 2011a, 2015). Further images are given for the sexually dimorphic structures on the prolateral aspect of the pedipalpal chela for the Bothriuridae which allows to easily differentiate genera in this family (Maury 1975a).

\section{Type catalogue}

Class Arachnida

Order Scorpiones C.L. Koch, 1850

Parvorder Iurida Soleglad \& Fet, 2003

\section{Family Bothriuridae Simon, 1880}

Type specimens belonging to 14 species are present at $\mathrm{ZMH}$. Types of one additional species were lost.

\section{Genus Bothriurus Peters, 1861}

\section{Bothriurus bocki}

Fig. 3A-B

\section{Bothriurus bocki Kraepelin, 1911: 91, 96-97, fig. 6}

Current combination. Bothriurus bocki Kraepelin, 1911

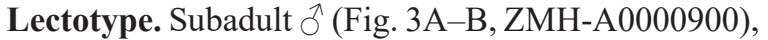
Bolivien [Bolivia], [La Paz], Sorata [1546'23"S, 6838'59’W], 09.1900, Charles Bock leg., ded. 8.05.1901.

Paralectotype. Subadult $\widehat{\partial}$ (ZMH-A0000900), same data as lectotype.

Remarks. Maury (1984) designated the specimen with 9-9 pectinal teeth as the lectotype and the other specimen as the paralectotype.

Remarks on collector. Charles Bock (1923-?) was a mining engineer who traveled to Bolivia and Argentina (Garth 1957). The specimen was probably collected during his travels.

\section{Bothriurus burmeisteri}

Fig. 3C-E

Bothriurus burmeisteri Kraepelin, 1894: 227-228, pl. III, fig. 104, 106

Current combination. Bothriurus burmeisteri Kraepelin, 1894.

Lectotype. $\widehat{\jmath}$ (Fig. 3C-E, ZMH-A0000901), Argentinien [Argentina], Hermann Burmeister leg., ded. 1891.

Paralectotype. Subadult $q$, same data as holotype.

Remarks. Weidner (1959) designated the holotype and paratype although there is no indication that the orig- inal description was based on the male rather than the female. Fixing a holotype after the original publication is not allowed. According to Article 73.1.3 of the Code (ICZN 2018) a holotype can only be designated in the original publication and by the original author. In case of a description based on more than one specimen, the Code recommends the designation of a lectotype (ICZN 2018: recommendation 73F). The adult male is therefore designated here as lectotype and the subadult female is the paralectotype.

Remarks on collector. Karl Hermann Konrad Burmeister (1807-1892) was a professor of zoology at the Martin Luther University of Halle-Wittenberg from 1837 to 1961 before he moved to Argentina and was appointed director of the National Museum in Buenos Aires. Before this appointment, he traveled to Uruguay and Argentina in late 1856 and returned with zoological collections to Germany (Bragg 2007). The type specimens of $B$. burmeisteri were probably collected during this expedition.

\section{Bothriurus catharinae}

Bothriurus catharinae Werner, 1939: 359-360, fig. 2

Current senior synonym. Bothriurus signatus Pocock, 1893 [synonymized by Maury 1973: 111].

Types (lost). Male and female syntypes destroyed according to Lowe and A00018662000). Primary data according to Werner (1939): Brazil, Santa Catarina, Joinville [26¹8'16"S, 48 50'44"W], Wilhelm Ehrhardt leg., 1 q, coll. 28.09.1898; 1 今े, coll. 07-08.1922.

Remarks on collector. Wilhelm Ehrhardt (1860 1936?) was a professional collector and taxidermist. He emigrated permanently from Hamburg in 1897 and moved to the state of Santa Catharina in South Brazil. For many years, he collected important series of vertebrate and invertebrate specimens on behalf of numerous museums and scientific institutions in Europe, e.g. the British Museum of Natural History London (BMNH), the Senckenberg Museum Frankfurt am Main (SMFD), the Zoologisches Museum München, the Zoologisches Museum Berlin (ZMB), the Zoologisches Museum Hamburg $(\mathrm{ZMH})$, the Universität Göttingen, and the Königliche Nervenklinik Tübingenthe (Gutsche et al. 2007).

\section{Bothriurus flavidus}

Fig. 4

Bothriurus flavidus Kraepelin, 1911: 89, 92-93, fig. 5

Current combination. Bothriurus flavidus Kraepelin, 1911

Lectotype. (Fig. 4D-E) Juvenile (ZMH-A0000902), Argentinien [Argentina], [Buenos Aires], Bahia Blan-

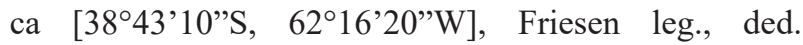
22.06 .1898 . 
A

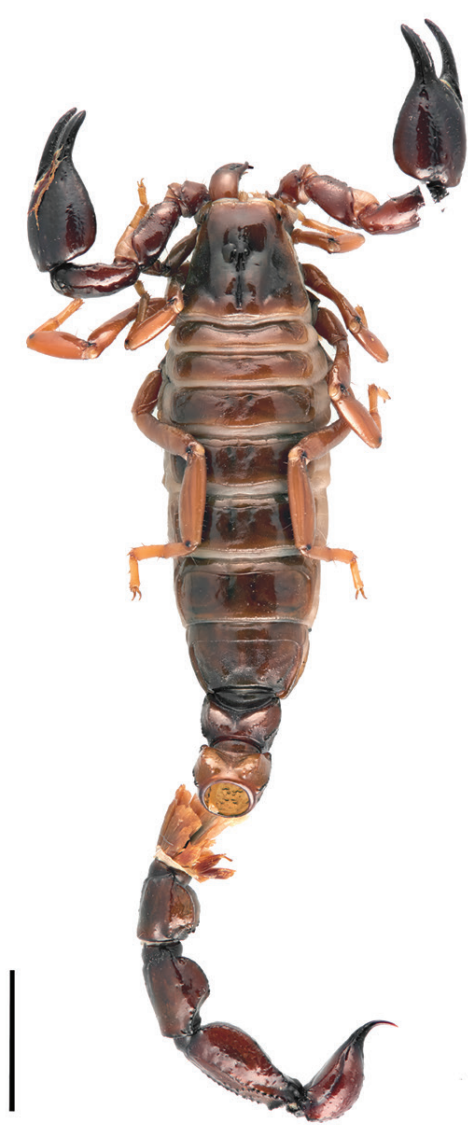

B

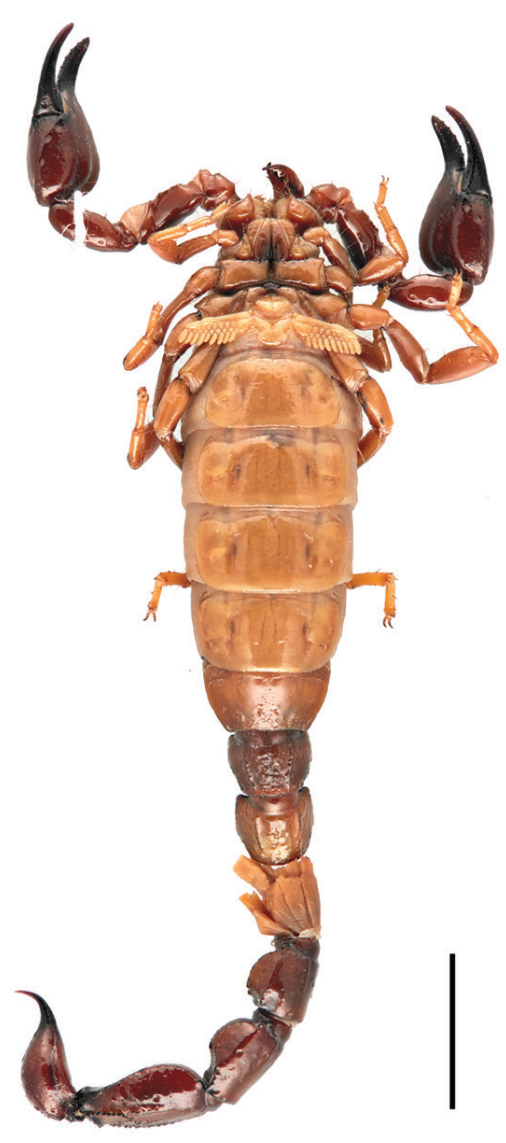

C

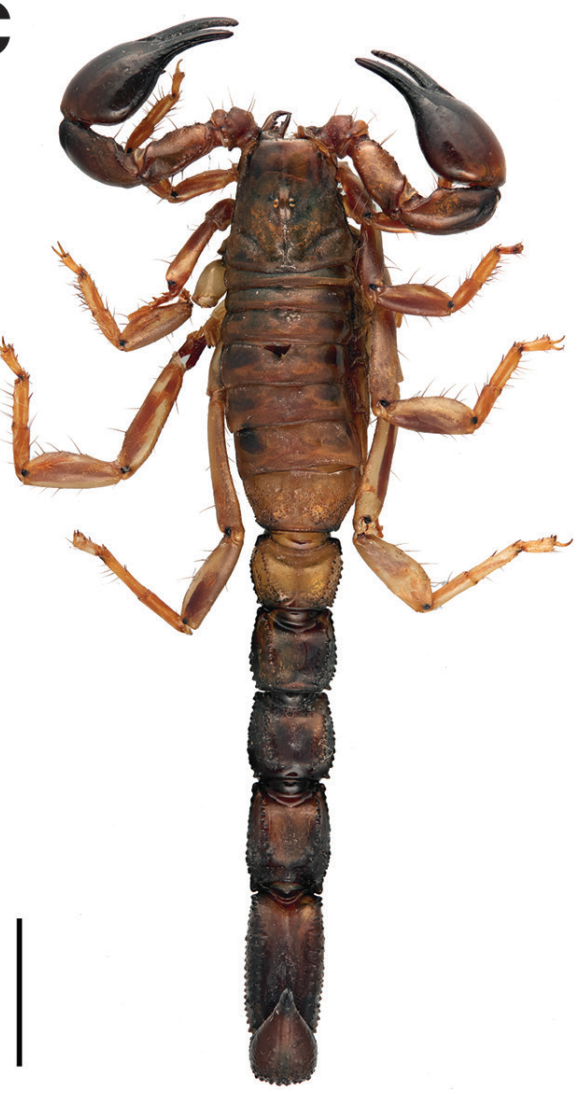

$\mathbf{E}$

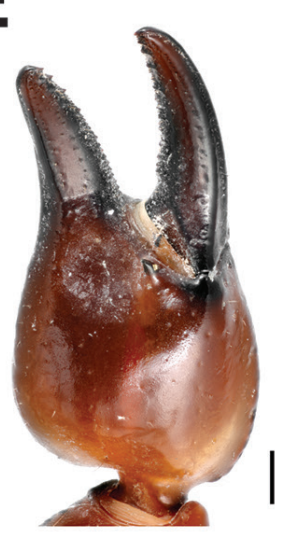

D

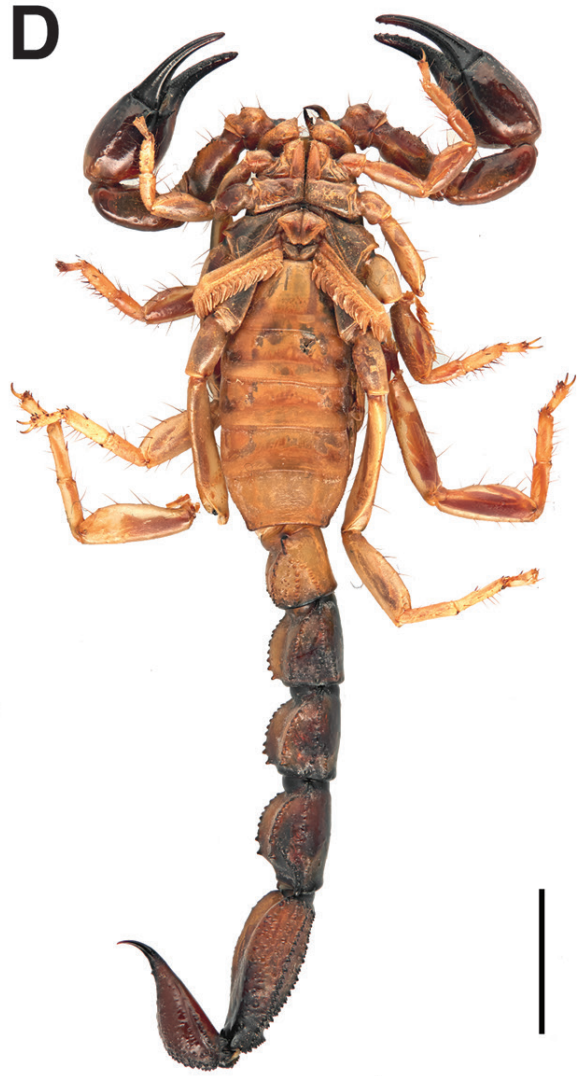

Figure 3. Bothriurus bocki Kraepelin, 1911, subadult male lectotype (A, B). Bothriurus burmeisteri Kraepelin, 1894, male lectotype $(\mathbf{C}-\mathbf{E})$ : A, $\mathbf{C}$ dorsal aspect of habitus $\mathbf{B}, \mathbf{D}$ ventral aspect of habitus $\mathbf{E}$ pro-lateral aspect of chela. Scale bars: $10 \mathrm{~mm}$. 

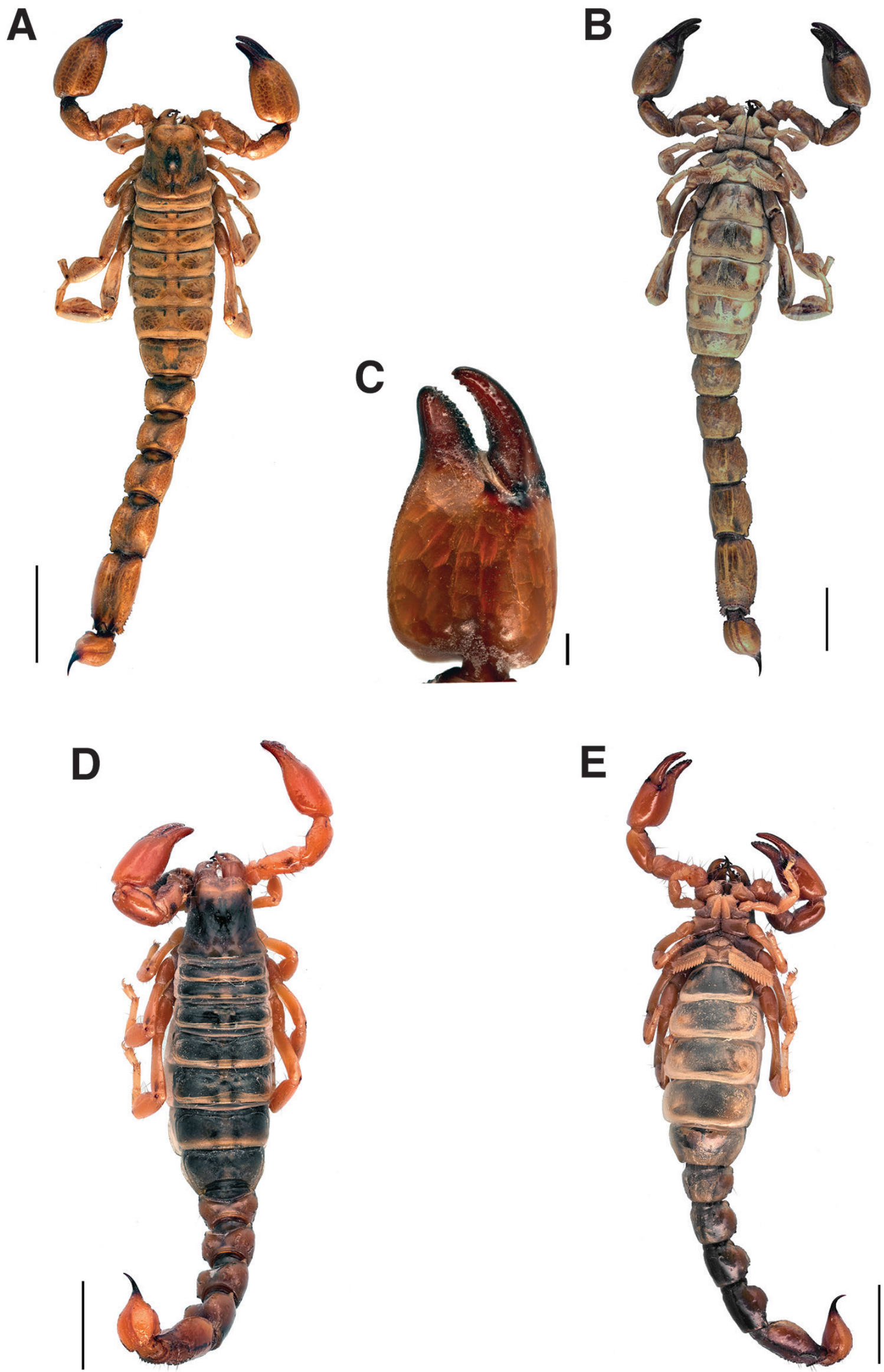

Figure 4. Bothriurus flavidus Kraepelin, 1911, male paratype (A-C), juvenile male holotype (D-E): A, D dorsal aspect of habitus $\mathbf{B}, \mathbf{E}$ ventral aspect of habitus $\mathbf{C}$ pro-lateral aspect of chela. Scale bars: $5 \mathrm{~mm}(\mathbf{A}-\mathbf{B}, \mathbf{D}-\mathbf{E}), 0.5 \mathrm{~mm}(\mathbf{C})$. 
Paralectotype. (Fig. 4A-C) $\widehat{\jmath}$ (ZMH-A0000903), Realgymnasium, locality unkown, coll. 1891.

Remarks. As type material, Kraepelin (1911) listed a juvenile from Bahia Blanca. This specimen is designated here as the lectotype. He also mentions the presence of a male without precise locality in the ZMH collections, which at that time were still housed at the "Realgymnasium" in Hamburg and only later moved to a new museum building. This specimen is a paralectotype.

\section{Bothriurus bonariensis maculatus}

Fig. 5

Bothriurus bonariensis maculatus Kraepelin, 1911: 89

Current combination. Bothriurus maculatus Kraepelin, 1911

Holotype. Subadult $\widehat{\jmath}$ (ZMH-A0002230), Bolivien [Bolivia], [La Paz], Tipuani [15³3’00”S, 6800'00”'W], L. A. von Leonhard leg.

Remarks. This specimen was donated to $\mathrm{ZMH}$ by A. von Leonard alongside "many snakes and 469 insects from Tipuani in Bolivia" (Kraepelin 1895b). No additional data are available.

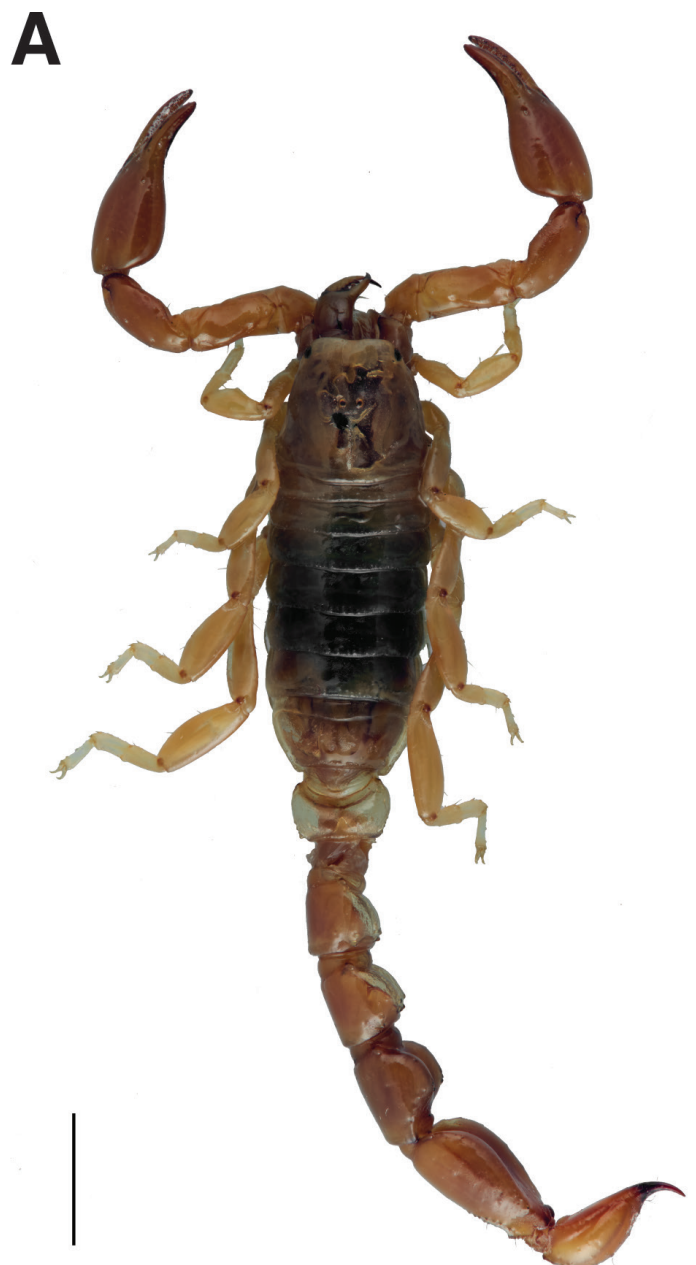

\section{Bothriurus bonariensis trivittatus}

Fig. 6

Bothriurus bonariensis trivittatus Werner, 1939: 358

Current combination. Bothriurus trivittatus Werner, 1939

Holotype. (Fig. 6D-F) q (metasoma broken) (ZMH-A000906), Bolivia, La Paz Province, Bez. Araca [Araca District] [1649'00”S, 67³3'00”W], $125 \mathrm{~km}$ südöstl. von La Paz [125 km SE of La Paz], $4200 \mathrm{~m}$, 10-12.1910-1916, Charles Bock leg., ded. 12.08.1921.

Paratypes. $1 \hat{\sigma}$ (Fig. $6 \mathrm{~A}-\mathrm{C}$ ), 1 क, 1 subadult $\hat{\delta}, 2$ subadult + , 1 juvenile (ZMH-A000906), Same data as holotype.

Probably not types. 1 subadult $\hat{\sigma}, 1$ (ZMH-A0002232), Bolivien [Bolivia], La Paz Province, Yungas District, Chulumani [16²4'30"S, 67³1'45”W], $125 \mathrm{~km}$ östl. von La Paz [125 km East of La Paz], 16002000m, 09-10.1916, Charles Bock leg., ded. 12.08.1921.

Remarks. Werner (1939) only mentioned one female from Araca with 15 pectinal teeth and this specimen should be considered as the holotype. The other specimens from the same series are paratypes by definition. Maury (1973) mentioned holotype and paratypes from Araca and cotypes from Chulumani. There is no evidence that Werner exam-

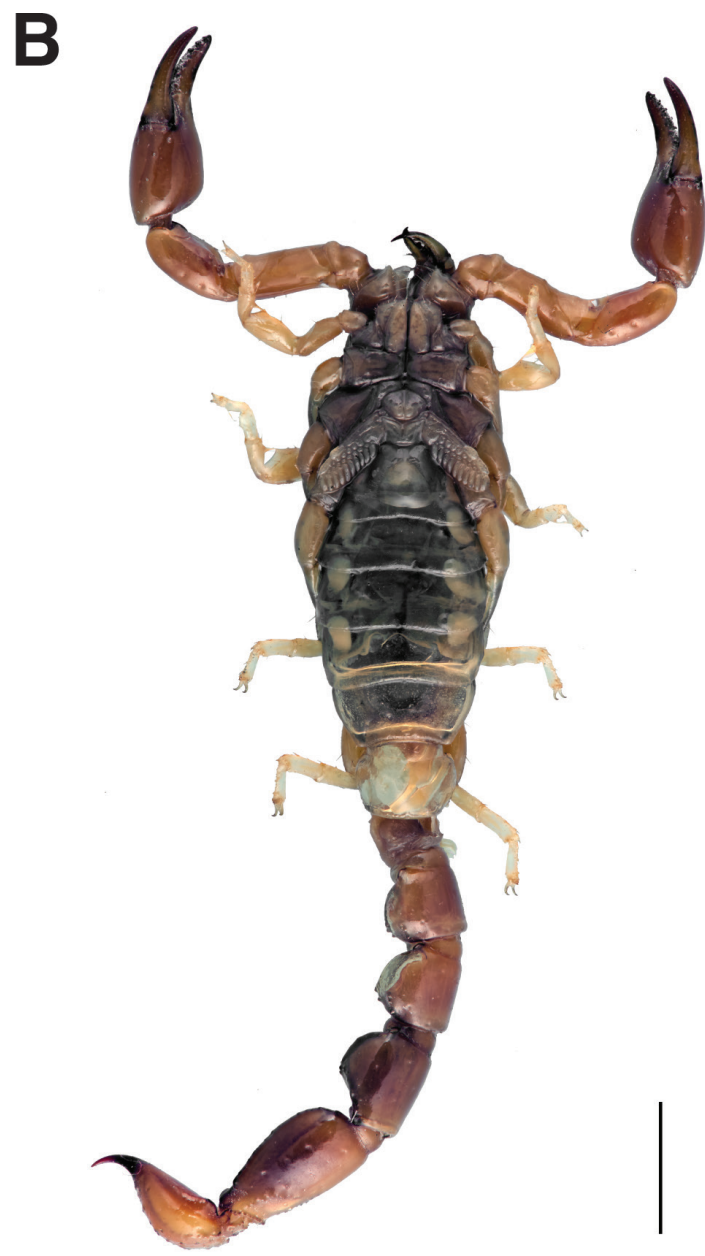

Figure 5. Bothriurus maculatus Kraepelin, 1911, subadult male holotype, habitus A dorsal aspect B ventral aspect. Scale bars: 5 mm. 


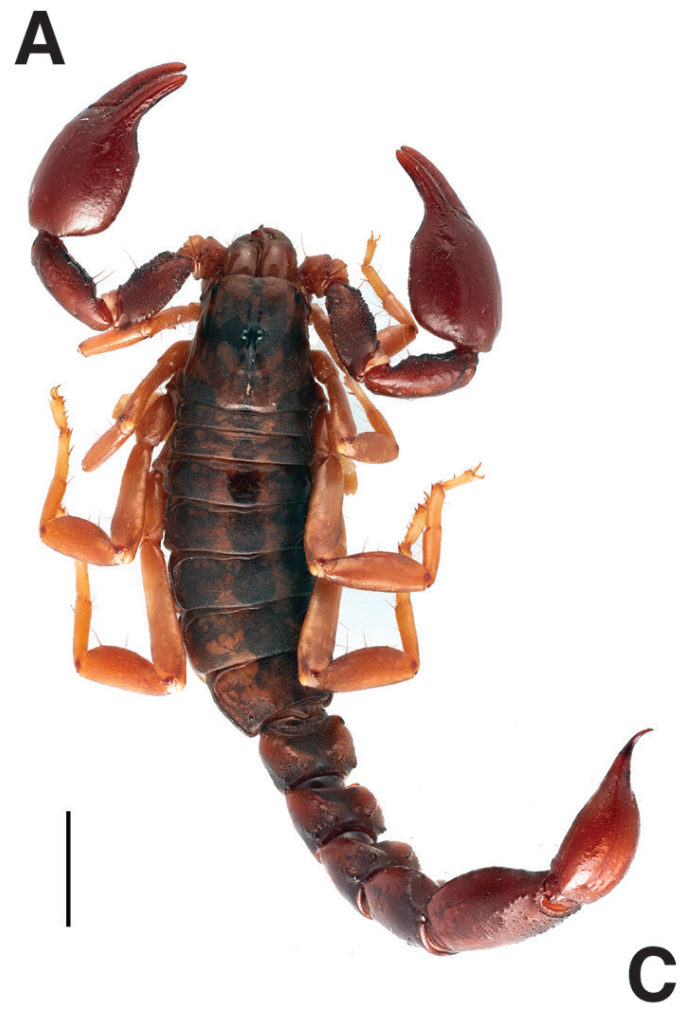

D

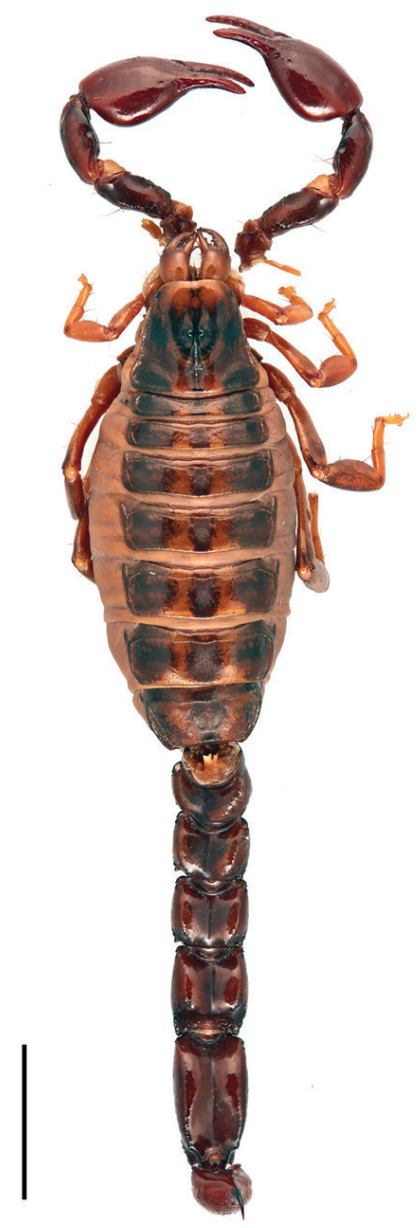

B

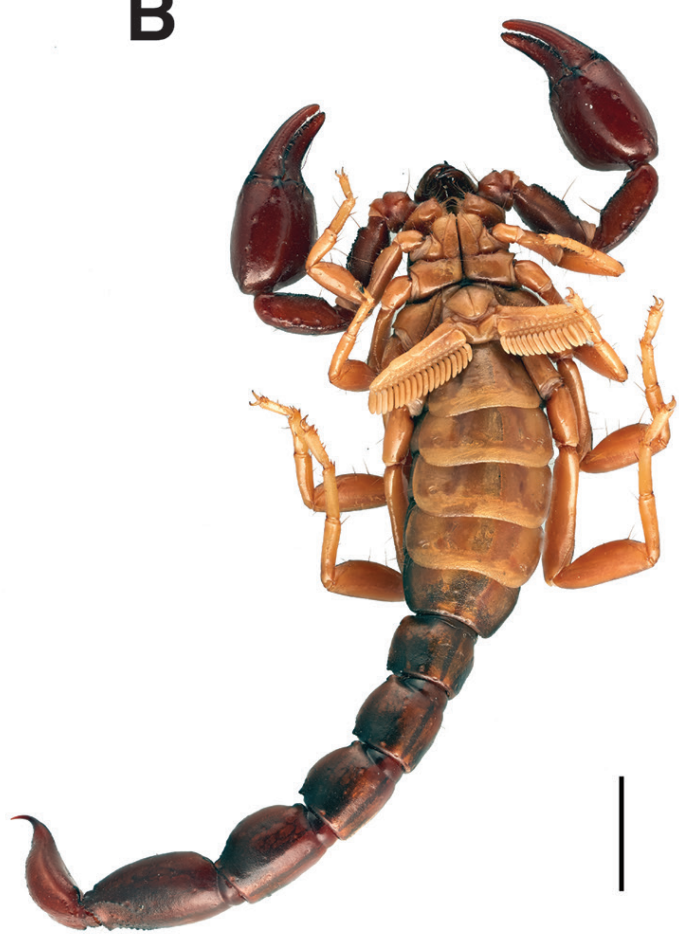

E

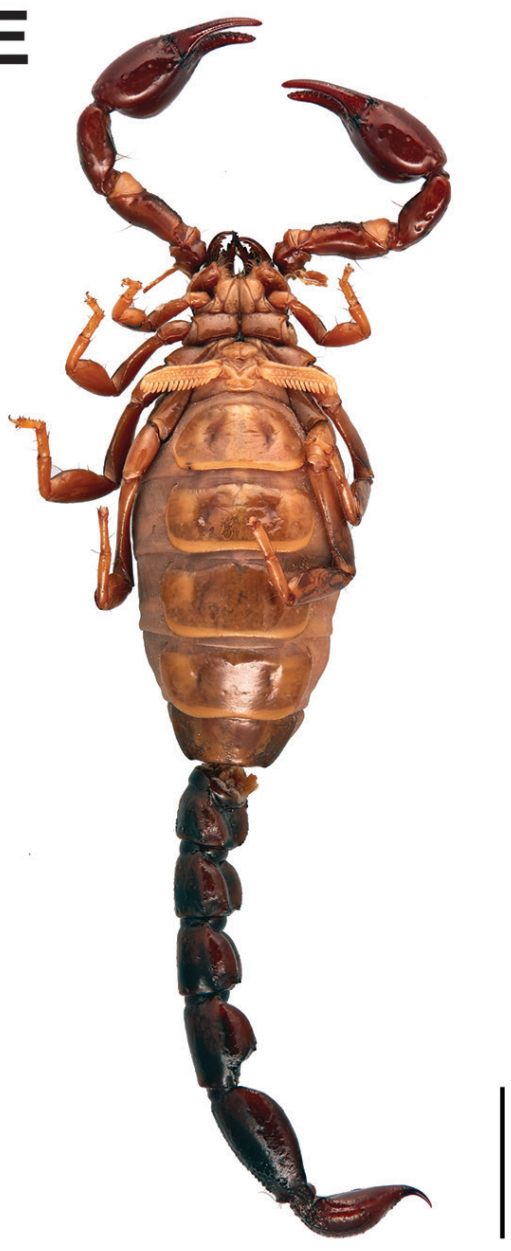

Figure 6. Bothriurus trivittatus Werner, 1939, male paratype (A-C), female holotype (D-F): A, D dorsal aspect of habitus B, E ventral aspect of habitus $\mathbf{C}, \mathbf{F}$ pro-lateral aspect of chela. Scale bars: $10 \mathrm{~mm}(\mathbf{A}-\mathbf{B}), 5 \mathrm{~mm}(\mathbf{D}-\mathbf{E}), 0.5 \mathrm{~mm}(\mathbf{C}, \mathbf{F})$. 
ined the material from Chulumani when naming the species and these specimens are probably not types. A specimen from the type series (ZMH-A000905) is labelled as belonging to a different species, probably by Maury who studied the material in 1970. No valid species name is, however, provided for this specimen and it may still be undescribed.

Remarks on collector. See paragraph on Bothriurus bocki Kraepelin, 1911 above.

\section{Genus Brachistosternus Pocock, 1893}

\section{Telegonus politus}

Fig. 7

Telegonus politus L. Koch, 1867: 234-235

Current senior synonym. Brachistosternus ehrenbergii (Gervais, 1841) [synonymized by Kraepelin 1894: 216]

Holotype. $\&$ (ZMH-A000940), Süd-Amerika [South America], Museum Godeffroy (No. 2244).

Remarks. The Museum Godeffroy was a private museum in Hamburg that existed between 1861-1885. Most arachnid specimens from its collections were integrated into the ZMH collections after the collapse of the Godeffroy estate and the closure of the Museum.

\section{Genus Brazilobothriurus Lourenço \& Monod, 2000}

\section{Brazilobothriurus pantanalensis}

Fig. 8

Brazilobothriurus pantanalensis Lourenço \& Monod, 2000: 146-151, figs 1-4, 7-14

Current combination. Brazilobothriurus pantanalensis Lourenço \& Monod, 2000

Paratypes. 1 ๙ (Fig. 8A-C, ZMH-A0000927), 1 ๙ (ZMH-A0002233), 1 9 (Fig. 8D-F, ZMH-A0000928), Brazil, Mato Grosso, Corumbá [1900’33”S, 57³9’12”W], S of Fazenda Salina (today Mato Groso do Sul), 12.VI.1963, E. Kleber leg. (collected with Tityus mattogrossensis).

Remarks. The holotype and three paratypes are deposited in the MHNG, eight paratypes at the MNHN, and three paratypes in the Museum Nacional do Rio de Janeiro
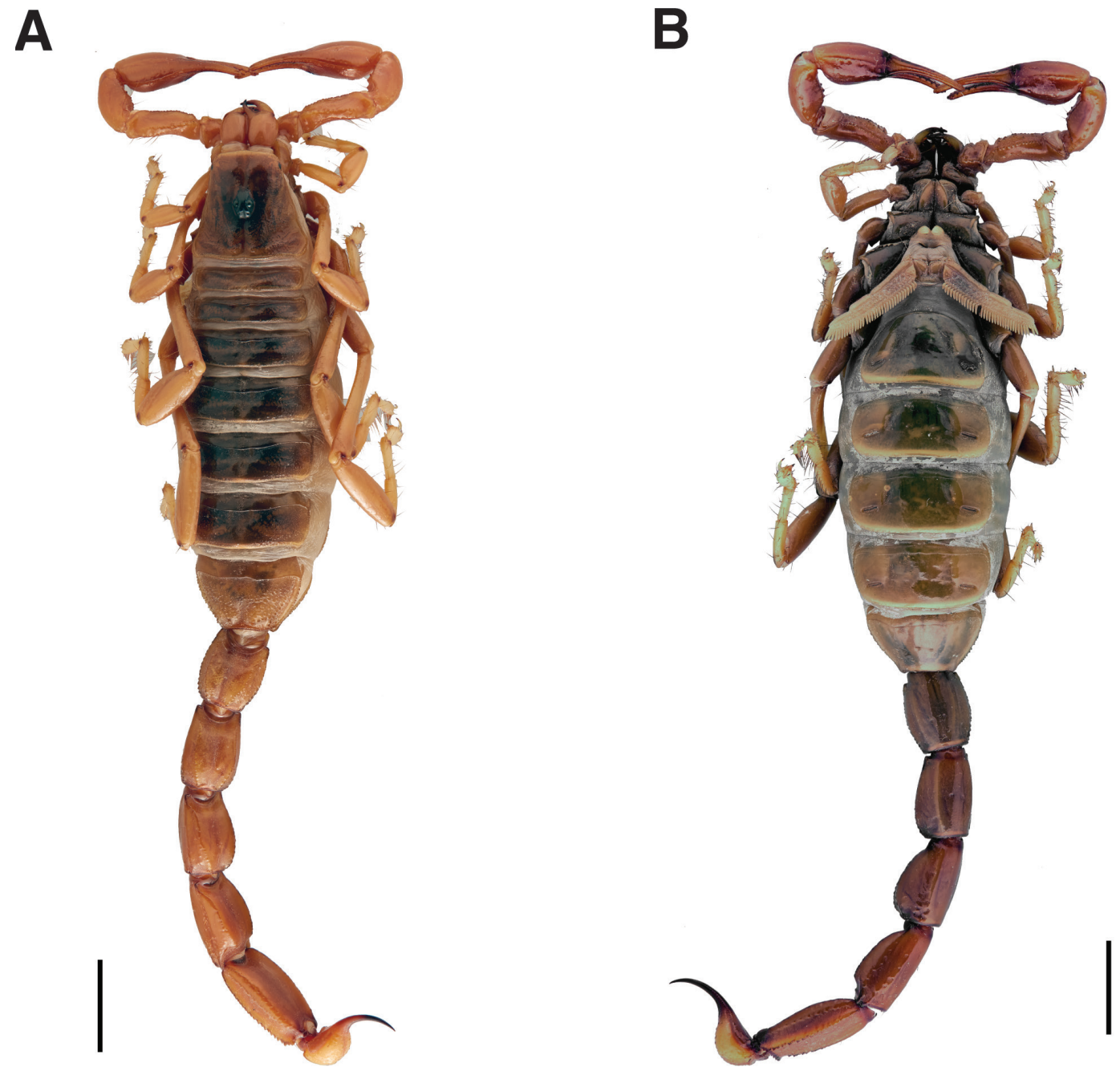

Figure 7. Telegonus politus L. Koch, 1867 [= Brachistosternus ehrenbergii (Gervais, 1841)], female holotype, habitus A dorsal aspect B ventral aspect. Scale bars: $10 \mathrm{~mm}$. 


\section{A}

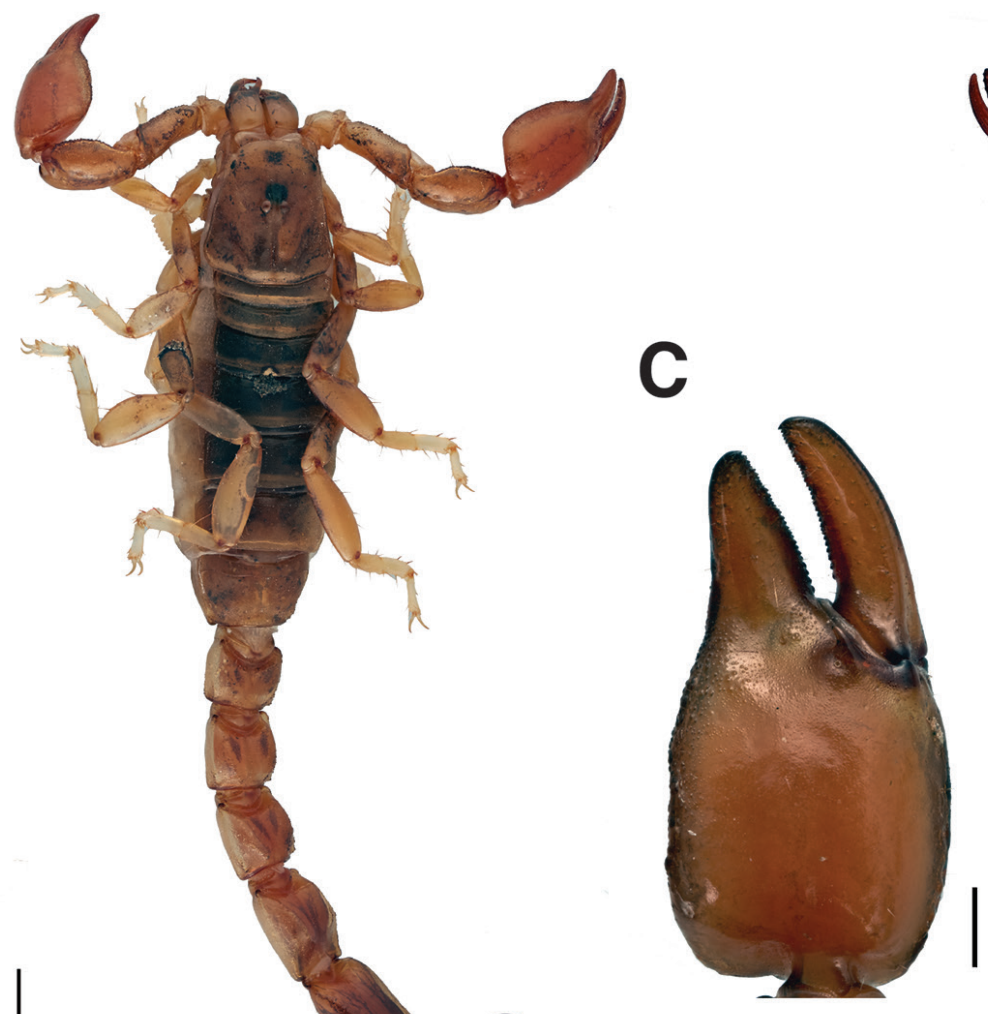

B

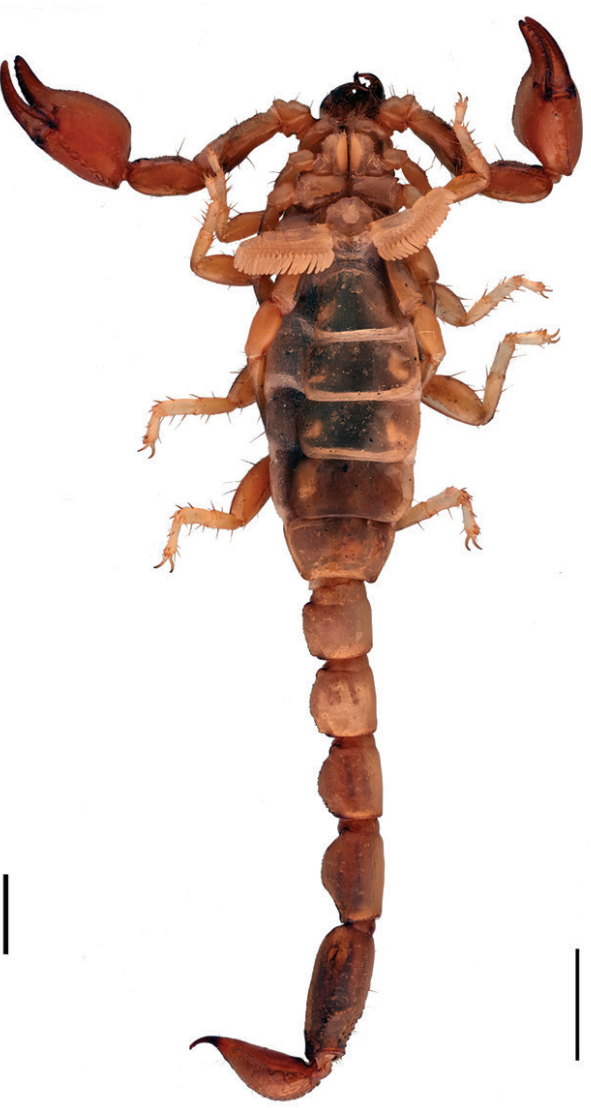

D

F
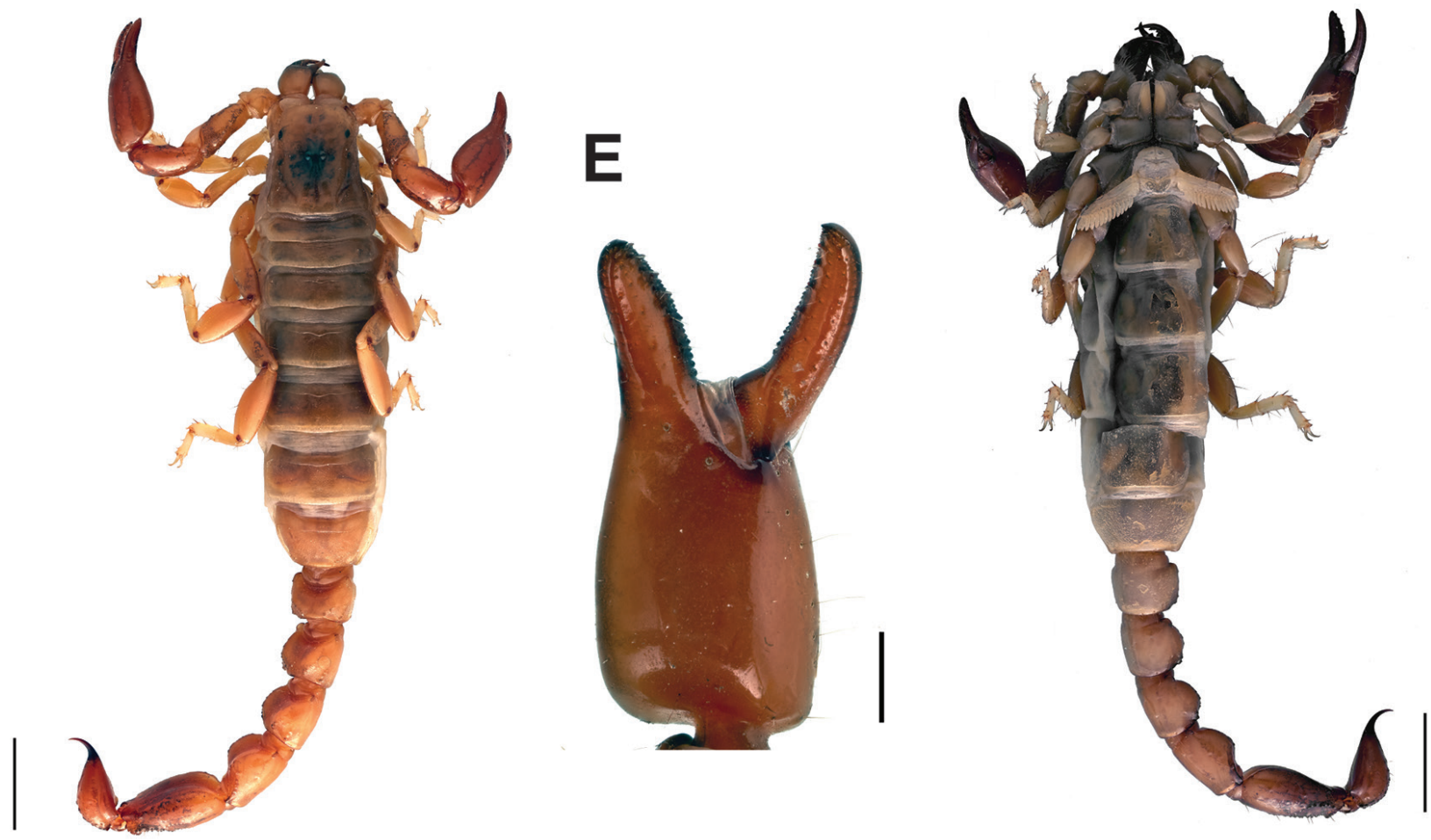

Figure 8. Brazilobothriurus pantanalensis Lourenço \& Monod, 2000, paratype (male) (A-C), female paratype (D-F): A, D dorsal aspect of habitus $\mathbf{B}, \mathbf{E}$ ventral aspect of habitus $\mathbf{C}, \mathbf{F}$ pro-lateral aspect of chela. Scale bars: $5 \mathrm{~mm}(\mathbf{A}-\mathbf{B}, \mathbf{D}-\mathbf{E}), 0.5 \mathrm{~mm}(\mathbf{C}, \mathbf{F})$. 
(MNRJ) (Lourenço and Monod 2000). These latter specimens were recently destroyed in the fire that consumed the MNRJ and its collections (02 September 2018).

\section{Genus Centromachetes Lönnberg, 1897}

\section{Bothriurus titschacki}

Fig. 9

Bothriurus titschacki Werner, 1939: 358-359, fig. 1

Current combination. Centromachetes titschacki (Werner,1939)

Holotype. (Fig. 9A-C) $\widehat{O}$ (ZMH-A0000907), Chile,

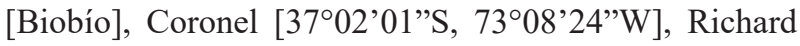
Paessler leg., ded. 15.01.1920.

Paratypes. $2 \AA$ (ZMH-A0002234), 1 (Fig. 9D-F, ZMH-A0000908), same data as holotype.

Paratypes. $6 \hat{\delta}, 1$ \& (ZMH-A0002235), Chile, [Biobío], Contulmo [3800'56”'S, 73¹3'47”W], 191415, Richard Paessler leg., ded. 15.01.1920.

Remarks. Werner (1939) described the species based on a male for which he provided measurements (holotype: total length $49 \mathrm{~mm}$, truncus [mesosoma] $20 \mathrm{~mm}$, cephalothorax [prosoma] $6 \mathrm{~mm}$, hand $9 \mathrm{~mm}$, pectinal teeth 9) and he also mentioned additional specimens (paratypes).

Remarks on collector. Richard Paessler (1886-1920) was a ship's captain, working for the firm Kosmos (Garth 1957). He published a list of birds observed in the region of Coronel in Chile when he visited the area from 1914 to 1918 (Pässler 1922).

\section{Genus Cercophonius Peters, 1861}

\section{Cercophonius granulosus}

Fig. 10

Cercophonius granulosus Kraepelin, 1908c: 102-103

Current combination. Cercophonius granulosus Kraepelin, 1908

Lectotype. 9 (Fig. 9A-B, ZMH-A0000909), [Western Australia], Moonyoonooka (station 82) [28 46 '51's, 11443'37'E], 13.07.1905, Wilhelm Michaelsen leg., Hamburg's South-West Australia Expedition 1905, ded. 06.1908.

Paralectotype. $q$ (ZMH-A0002236), Western Austra-

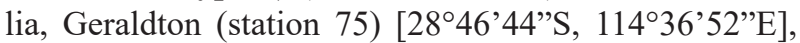
16.07.1905, Wilhelm Michaelsen leg., Hamburg's SouthWest Australia Expedition 1905, ded. 06.1908.

Remarks. Kraepelin (1908c) listed 2 females from Moonyoonooka and 1 juvenile from Geraldton. Acosta (1990) noted that the material was only composed of 1 female from Moonyoonooka and 1 female from Geraldton, with no trace of a juvenile specimen. The female from Moonyoonooka erroneously considered as holotype by Weidner (1959) was designated as lectotype and the remaining specimen as paralectotype by Acosta (1990).
Remarks on collector. J. Wilhelm Michaelsen (18601937) was a curator at the ZMH and a specialist of Oligochaeta (Monro 1937; Sherlock and Berridge 2012). He undertook three major expeditions to Chile, South Africa and Western Australia (see Harms and Dupérré 2018 for details). In 1905, the Berlin and Hamburg Museums organized a major expedition to southwestern Australia that was led by Michaelsen and Robert Hartmeyer (Michaelsen and Hartmeyer 1907 [see travel map for detail of collecting localities]). Numerous spiders (Araneae) species were described by Simon $(1908,1909)$ based on the material collected during this expedition. The type specimens of these species are lodged in the Western Australian Museum (Main and Harvey 1992). Interestingly, the type specimens of Australian scorpion species described by Kraepelin based on material collected during the same expedition were not sent back to Australia but remained in the collections of the Hamburg Museum.

\section{Cercophonius michaelseni}

Fig. 11

Cercophonius michaelseni Kraepelin, 1908c: 102-103

Current combination. Cercophonius michaelseni Kraepelin, 1908

Lectotype. (Fig. 11A-B) $\&$ (ZMH-A0000933), [West-

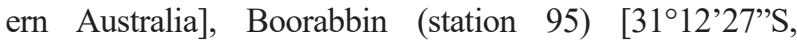
$120^{\circ} 18^{\prime} 31$ 'E], 22.09.1905, Wilhelm Michaelsen leg., Hamburg's South-West Australia Expedition 1905, ded. 06.1908.

Paralectotype. (Fig. 11C-D) subadult $\hat{O}$ (ZMH-A0000933), same data as lectotype.

Remarks. Kraepelin (1908c) listed 2 females and one male (but he was unsure the specimen was a male) as type material. Weidner (1959) erroneously considered the female as holotype and the male as paratype. Acosta (1990) examined three syntypes and designated the female as lectotype and the remaining specimens as paralectotypes. One specimen from the type series is deposited in the Berlin Natural History Museum (ZMB/Arach-15396).

Remarks on collector. See paragraph on Cercophonius granulosus Kraepelin, 1908 above.

\section{Cercophonius sulcatus}

Fig. 12

Cercophonius sulcatus Kraepelin, 1908c: 102-103

Current combination. Cercophonius sulcatus Kraepelin, 1908

Lectotype. (Fig. 12A-B) + (ZMH-A0000930),

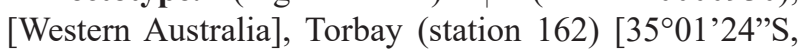
117³9'38'E], 19.08.1905, Wilhelm Michaelsen leg., Hamburg's South-West Australia Expedition 1905, ded. 06.1908.

Paralectotypes. (Fig. 12C-D) subadult (ZMH-A0000930), same data as lectotype; 

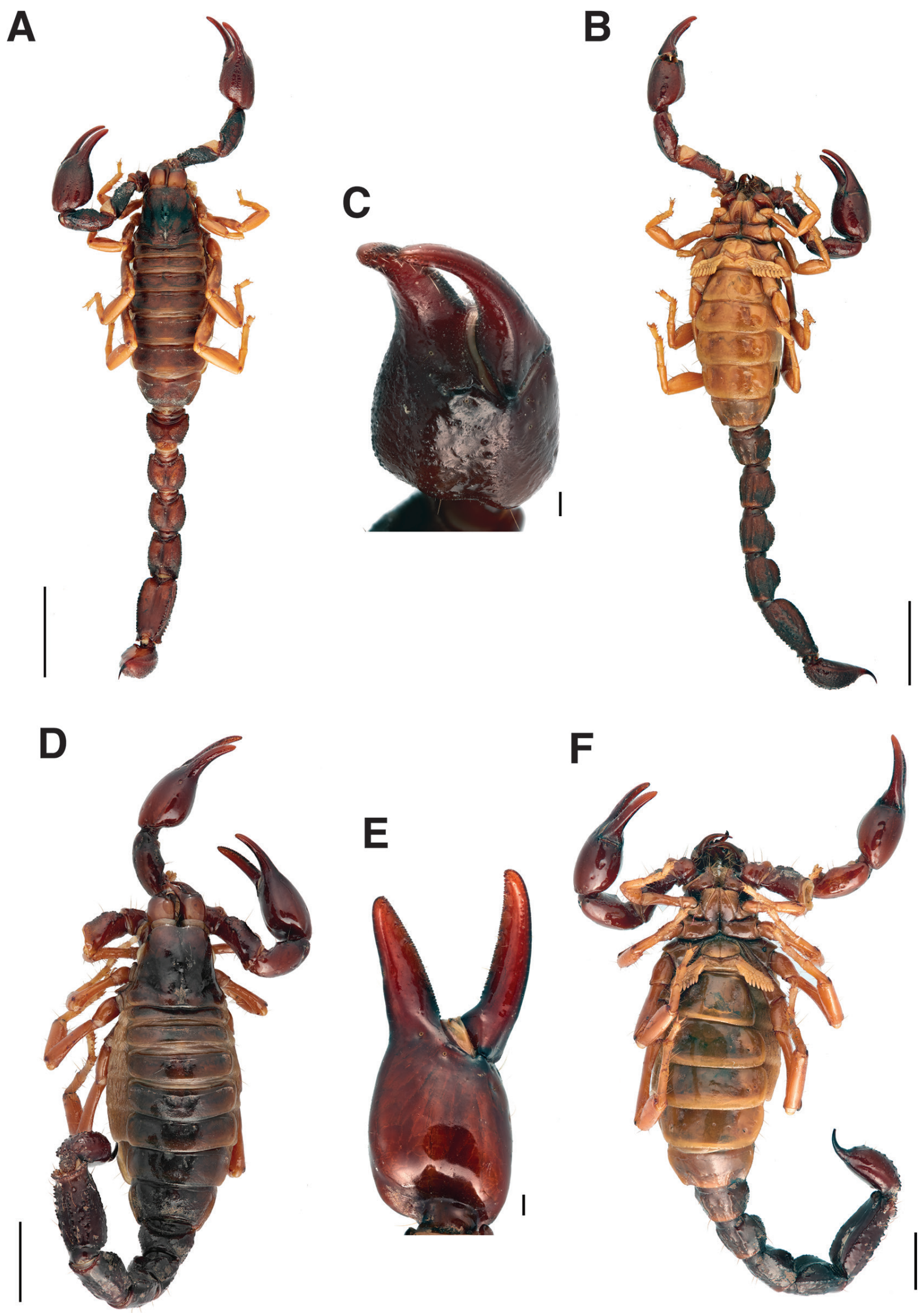

Figure 9. Bothriurus titschacki Werner, 1939 [= Centromachetes titschacki (Werner,1939)], male holotype (A-C), female paratype (D-F): A, D dorsal aspect of habitus B, E ventral aspect of habitus $\mathbf{C}, \mathbf{F}$ pro-lateral aspect of chela. Scale bars: $10 \mathrm{~mm}(\mathbf{A}-\mathbf{B}, \mathbf{D}-\mathbf{E})$, $0.5 \mathrm{~mm}(\mathbf{C}, \mathbf{F})$. 

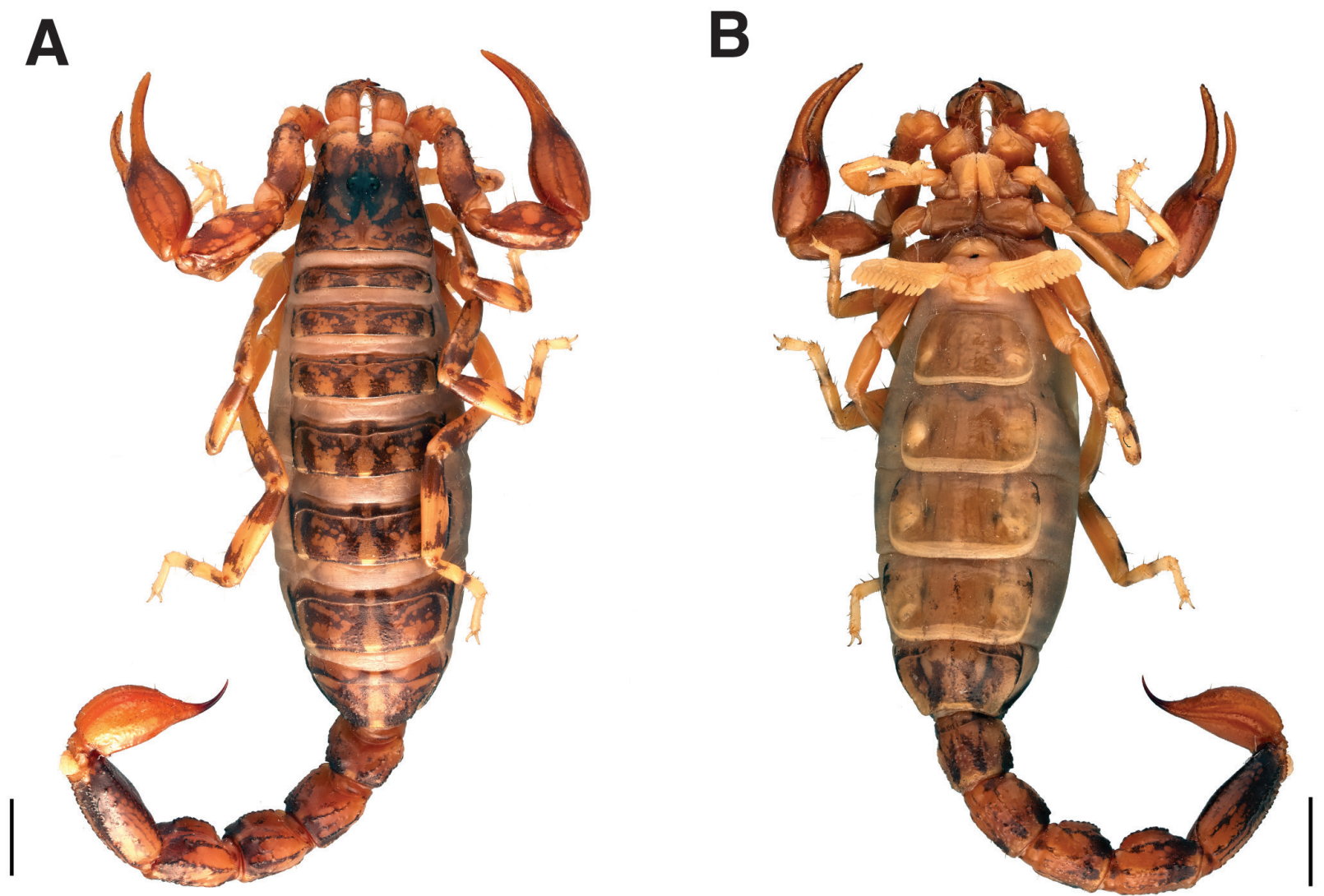

Figure 10. Cercophonius granulosus Kraepelin, 1908, female lectotype, habitus A dorsal aspect B ventral aspect. Scale bars: $10 \mathrm{~mm}$.

(ZMH-A0001061), [Western Australia], Lunenberg (station 138) [3320’06”S, $116^{\circ} 02^{\prime} 08^{\prime}$ 'E], 22.09.1905, Wilhelm Michaelsen leg., Hamburg's South-West Australia Expedition 1905, ded. 06.1908; juvenile (ZMH-A0002237), [Western Australia], South Albany (station 167) [3501'36’'S, $\left.117^{\circ} 53^{\prime} 01^{\prime \prime} \mathrm{E}\right], 06.1905$, Wilhelm Michaelsen leg., Hamburg's South-West Australia Expedition 1905, ded. 06.1908.

Remarks. Kraepelin (1908c) and Acosta (1990) listed 7 specimens as type material. Acosta (1990: 18) designated the female from Torbay as lectotype and the remaining specimens as paralectotypes. Three specimens from the original series are lodged in the collections of the Berlin Museum (ZMB): 1 juvenile (ZMB/Arach-15397), Collie (station 137); 2 juveniles (ZMB/Arach-15398), Boyanup (station 146). Lunenburg was an old settlement near the current town of Dwellingup in southwestern Australia.

Remarks on collector. See paragraph on Cercophonius granulosus Kraepelin, 1908 above.

\section{Genus Orobothriurus Maury, 1975}

\section{Bothriurus curvidigitus}

Fig. 13

Bothriurus curvidigitus Kraepelin, 1911: 91, 97-98, fig. 7

Current combination. Orobothriurus curvidigitus (Kraepelin, 1911)
Lectotype. $\widehat{~}$ (Fig. 13A-C, ZMH-A0000914), Peru, [Arequipa Province], Yura [16 $07^{\prime} 51^{\prime \prime S}, 71^{\circ} 36^{\prime} 22^{\prime} \mathrm{W}$ ], coll. 20.VI.1909, Museum Wiesbaden.

Paralectotype. Subadult $q$ (ZMH-A0000914), same data as lectotype.

Remarks. Kraepelin (1911) listed one male and one juvenile female from the $\mathrm{ZMH}$ collections. His description is not based on a specific specimen and Maury (1975b: 18-19) designated a holotype and an allotype a posteriori. As fixing a holotype after the original publication is not an accepted practice (ICZN 2018: article 73.1.3; see paragraph on Bothriurus burmeisteri Kraepelin, 1894 above), the male is designated here as the lectotype, and the female is the paralectotype.

\section{Bothriurus paessleri}

Fig. 14

Bothriurus paessleri Kraepelin, 1911: 91, 98-99, figs 8-9

Current combination. Orobothriurus paessleri (Kraepelin, 1911)

Lectotype. (Fig. 14A-C) $\hat{~}$ (ZMH-A0000904), Peru, [Arequipa Department], [Islay Province], Kataringo [Catarindo] [17\%01'08'S, 72 $01^{\prime} 54^{\prime \prime} \mathrm{W}$ ], Thal $1.5 \mathrm{ml}$ nördlich von Mollendo [Valley, 1.5 miles North of Mollendo], 15.11.1906, Captain Richard Paessler leg., ded. 25.02.1907. 
A

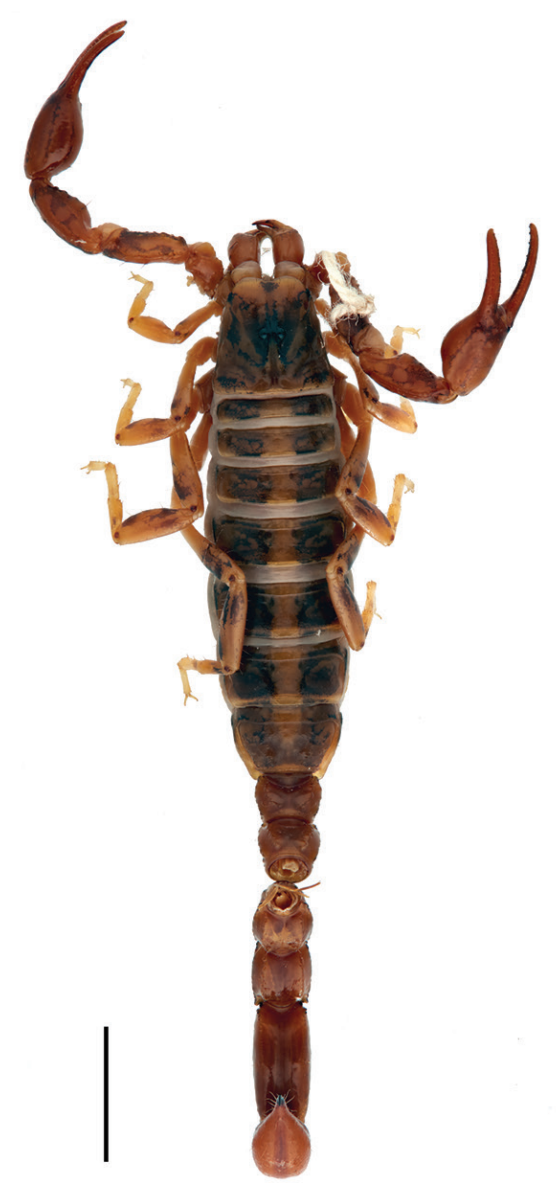

C

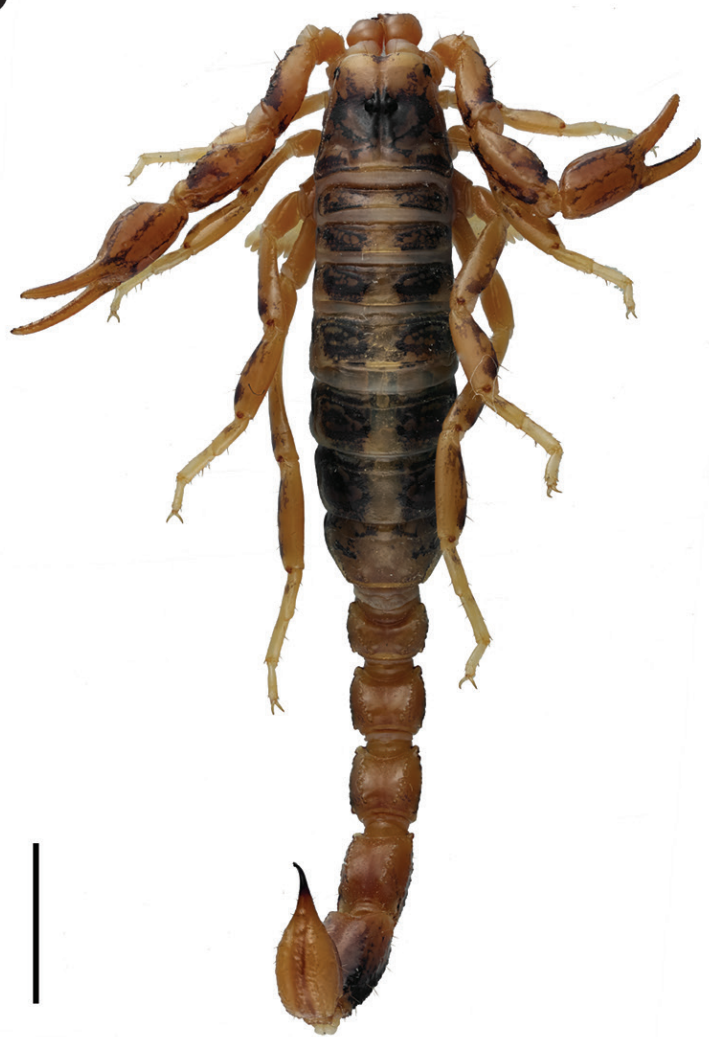

B

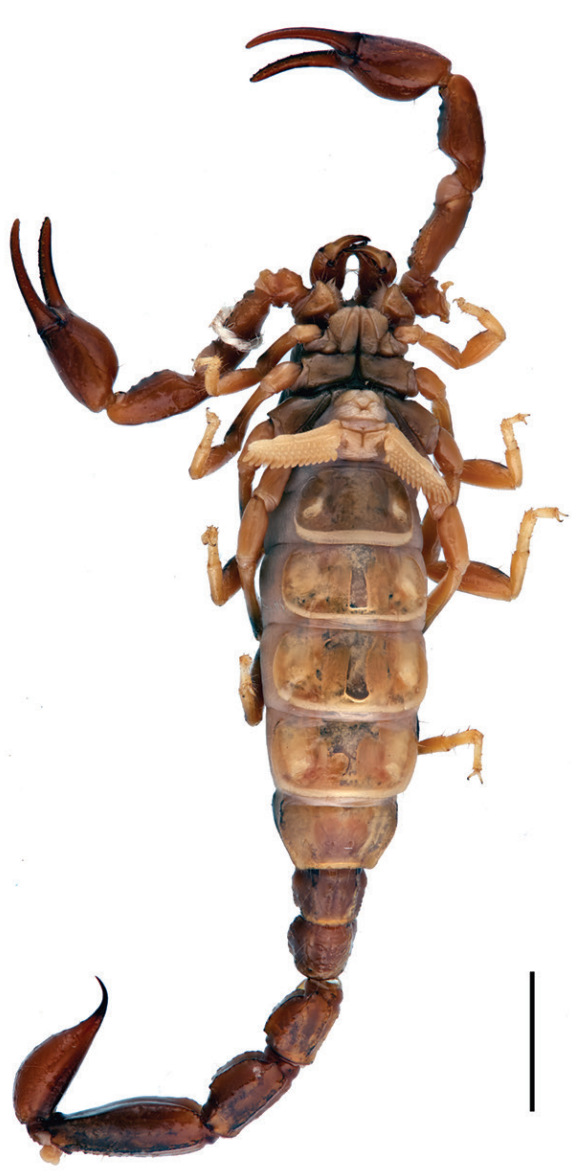

D

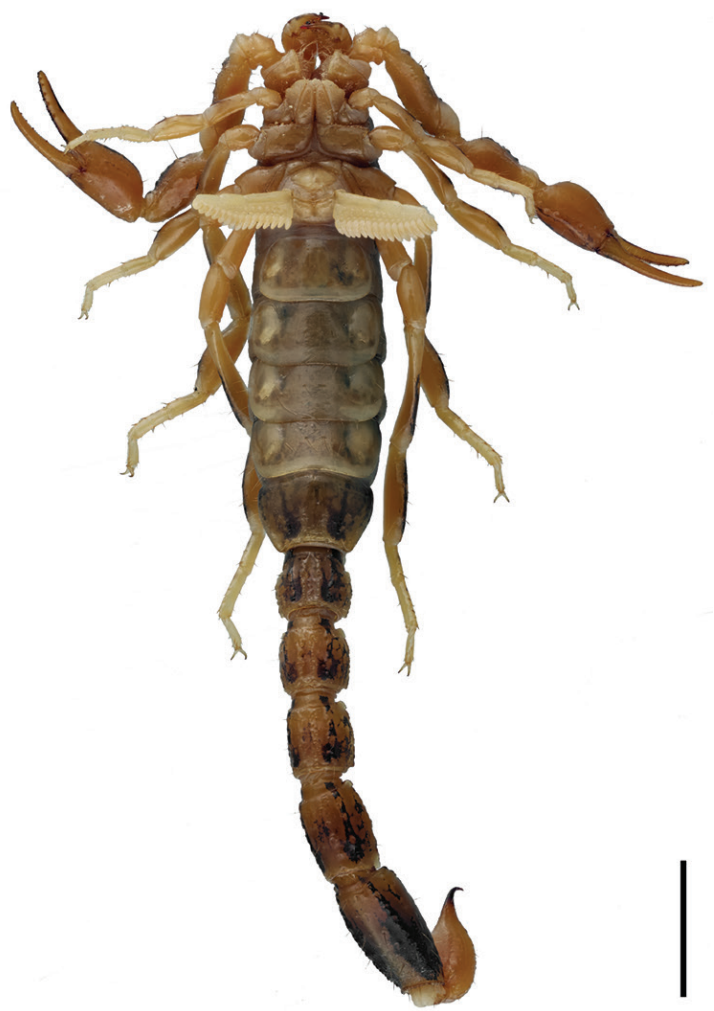

Figure 11. Cercophonius michaelseni Kraepelin, 1908, female lectotype (A-B), subadult male paralectotype (C-D): A, C dorsal aspect of habitus B, D ventral aspect of habitus. Scale bars: $10 \mathrm{~mm}(\mathbf{A}-\mathbf{B}), 5 \mathrm{~mm}(\mathbf{C}-\mathbf{D})$. 
A

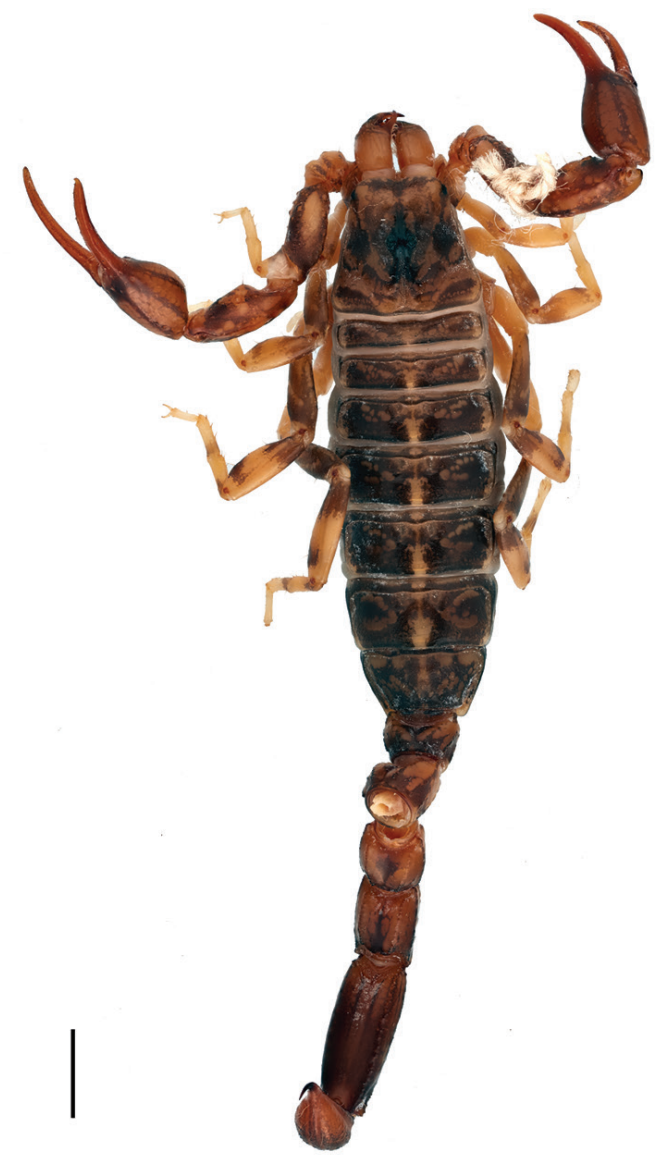

C

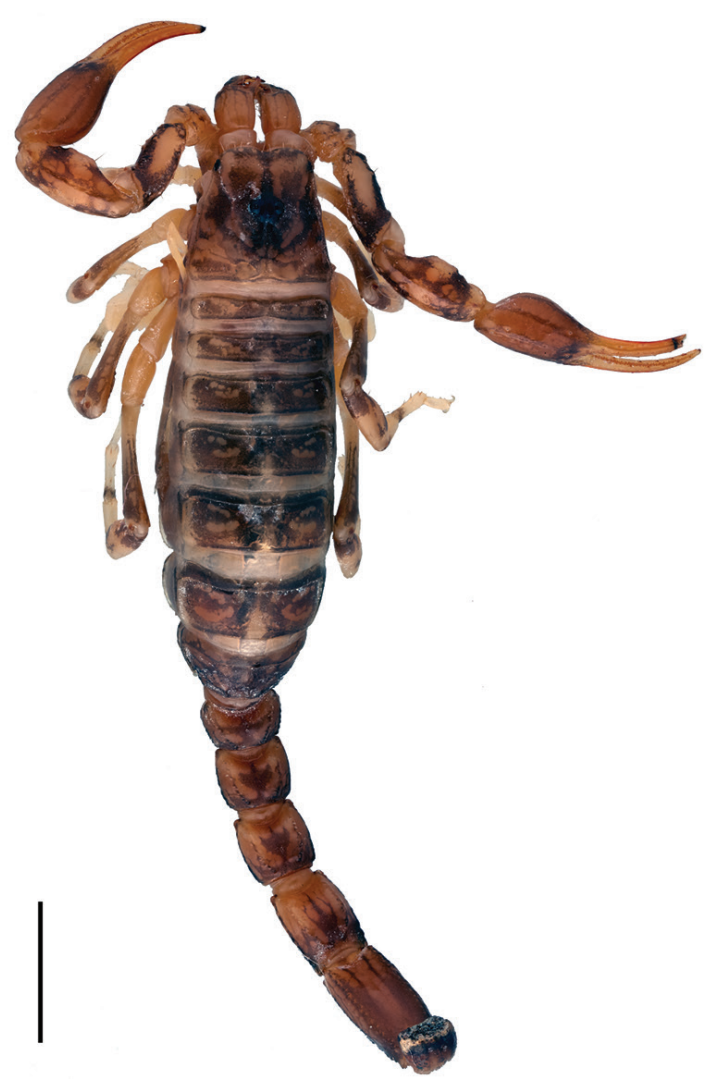

B

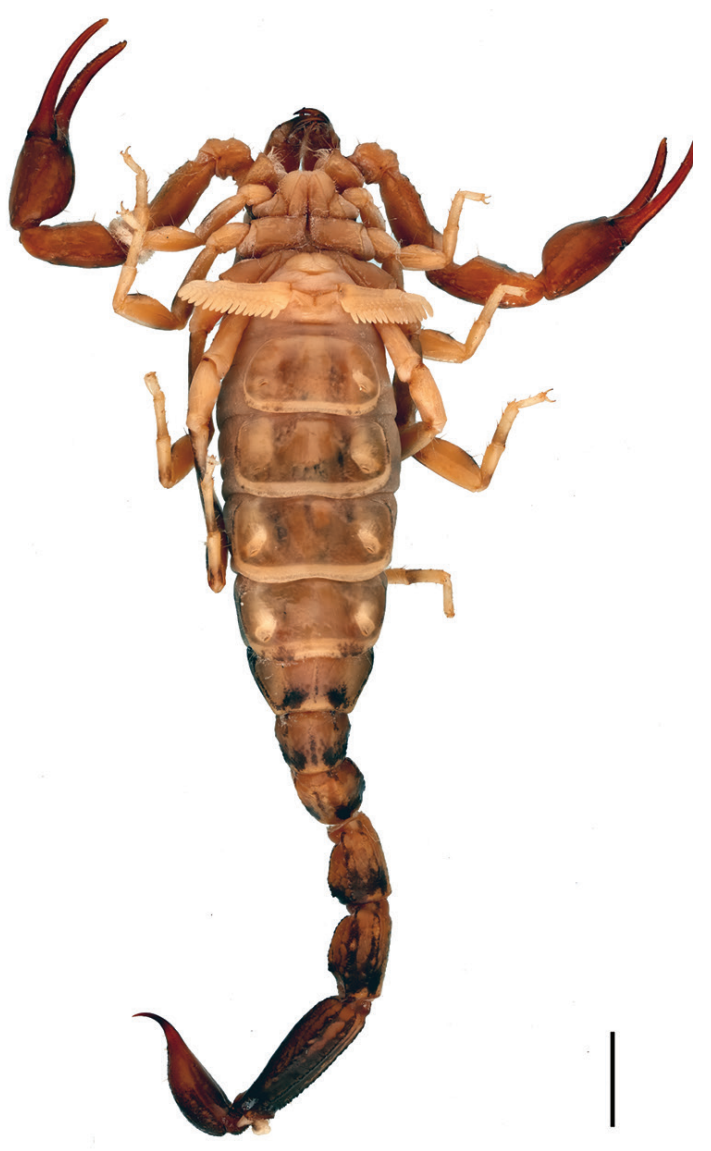

D

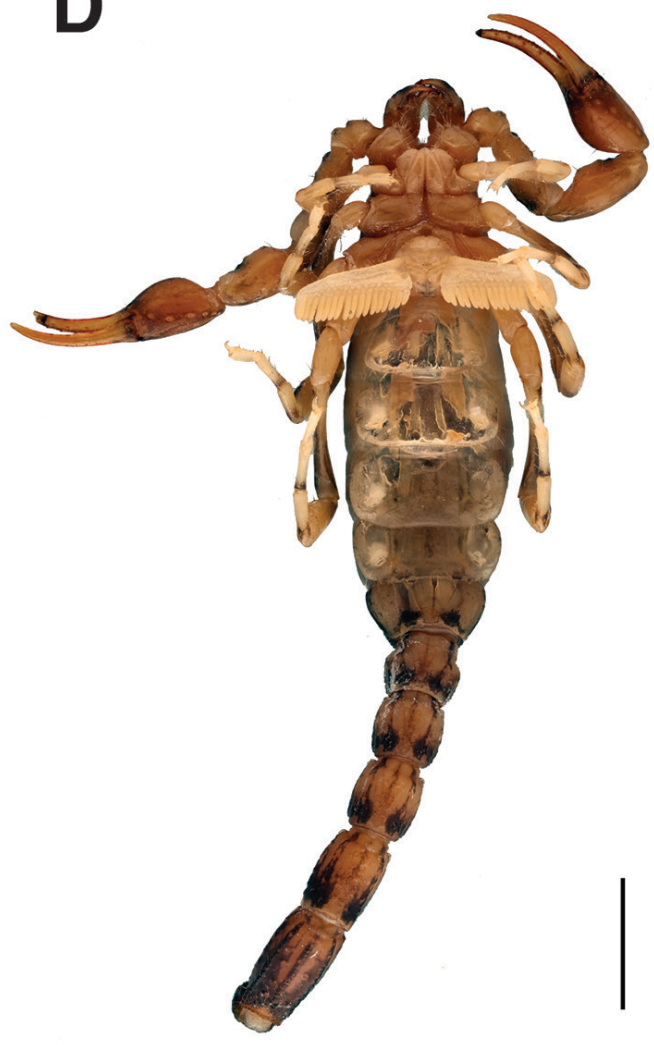

Figure 12. Cercophonius sulcatus Kraepelin, 1908, female lectotype (A-B), subadult male paralectotype (C-D): A, C dorsal aspect of habitus B, D ventral aspect of habitus. Scale bars: $5 \mathrm{~mm}$. 


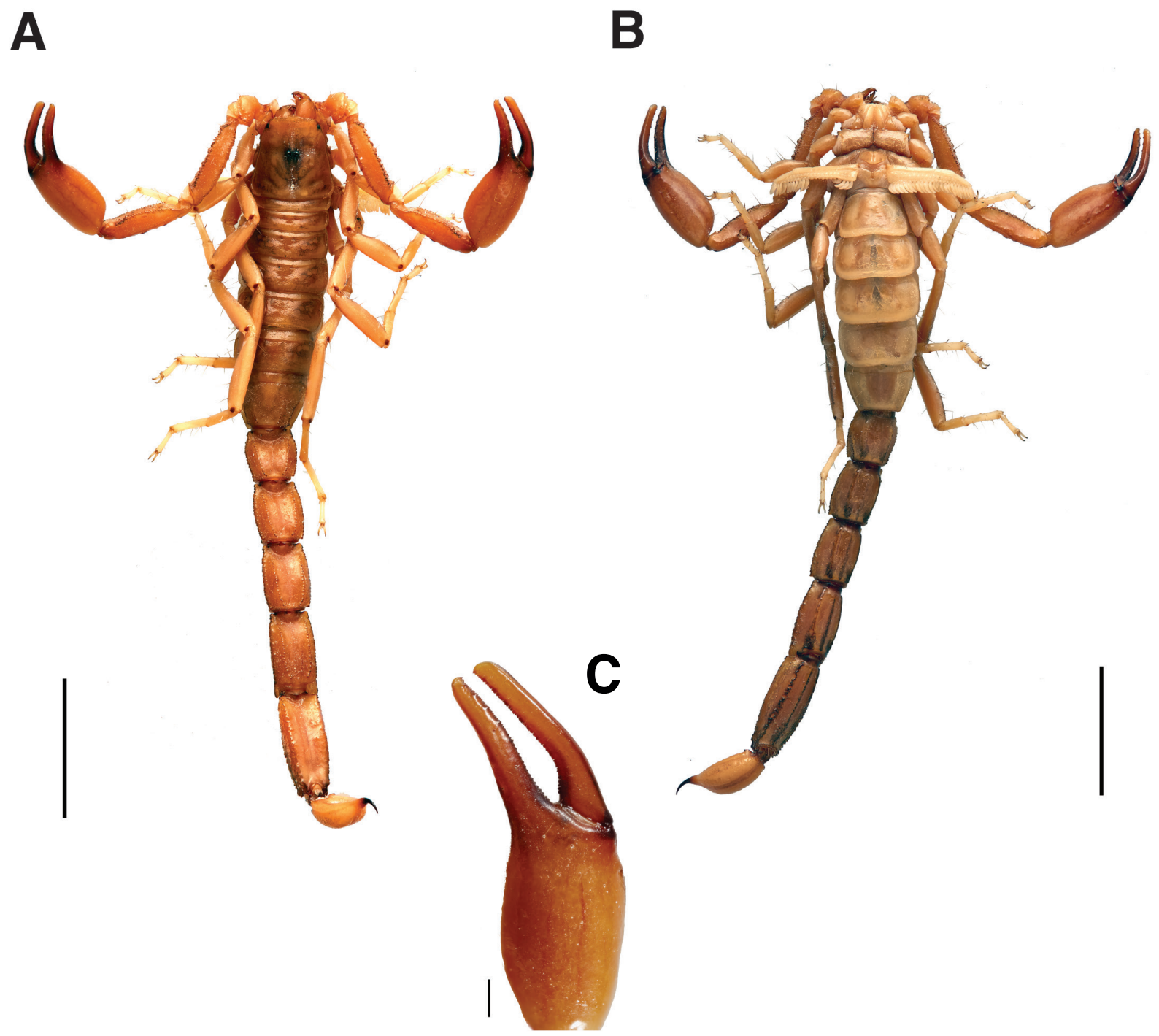

Figure 13. Bothriurus curvidigitus Kraepelin, 1911 [= Orobothriurus curvidigitus (Kraepelin, 1911)], male lectotype A dorsal aspect of habitus $\mathbf{B}$ ventral aspect of habitus $\mathbf{C}$ pro-lateral aspect of chela. Scale bars: $10 \mathrm{~mm}(\mathbf{A}-\mathbf{B}), 1 \mathrm{~mm}(\mathbf{C})$.

Paralectotypes. (Fig. 14D-F) 우 (ZMH-A0000904), same data as lectotype; subadult $\widehat{\partial}$ (ZMH-A0002231), Peru, [Arequipa Department], Thal Kataringo bei Mollendo [Valley of Catarindo, near Mollendo], 3.12.1907, Captain Richard Paessler leg., ded. 11.03.1908.

Remarks. Kraepelin (1911) listed one male and three females from Kataringo. One male (holotype), one female (allotype) and two additional females were examined and listed for the type series by Maury (1975b: 20). Ochoa et al. (2011) listed 4 syntypes ( 1 male and 3 females) but only three specimens could be found in the ZMH collections and the fourth is lost. For reasons given above (see paragraph on Orobothriurus curvidigitus (Kraepelin, 1911)), the male is designated here as the lectotype and the remaining specimens are paralectotypes.

Remarks on collector. See paragraph on Centromachetes titschacki Werner, 1939 above.

\section{Genus Phoniocercus Pocock, 1893}

\section{Cercophonius himalayensis}

Cercophonius himalayensis Lourenço, 1996: 87-89

Current senior synonym. Phoniocercus sanmartini Cekalovic, 1968 [synonymyized by Ojanguren-Affilastro et al. 2018: 474, 477]

Holotype. $\widehat{O}$ (ZMH-A0001581), India, Himalaya, [Uttarakhand] Ukal, Pauri Garhwal, U.P., 308N-7850E [30 $\left.09^{\prime} 00^{\prime \prime} \mathrm{N}, 78^{\circ} 50^{\prime} 00^{\prime \prime} \mathrm{E}\right]$, about $45 \mathrm{~km}$ from the

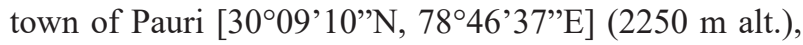
16.05.1958, F. Schmid leg. (ZMH, Eing. Nr. A40/96).

Remarks. Ojanguren-Affilastro et al. (2018) considered that the specimen was mislabelled (it was probably collected in Chile and not in India like it is stated on the label). They explained that the entomologist Fernand 


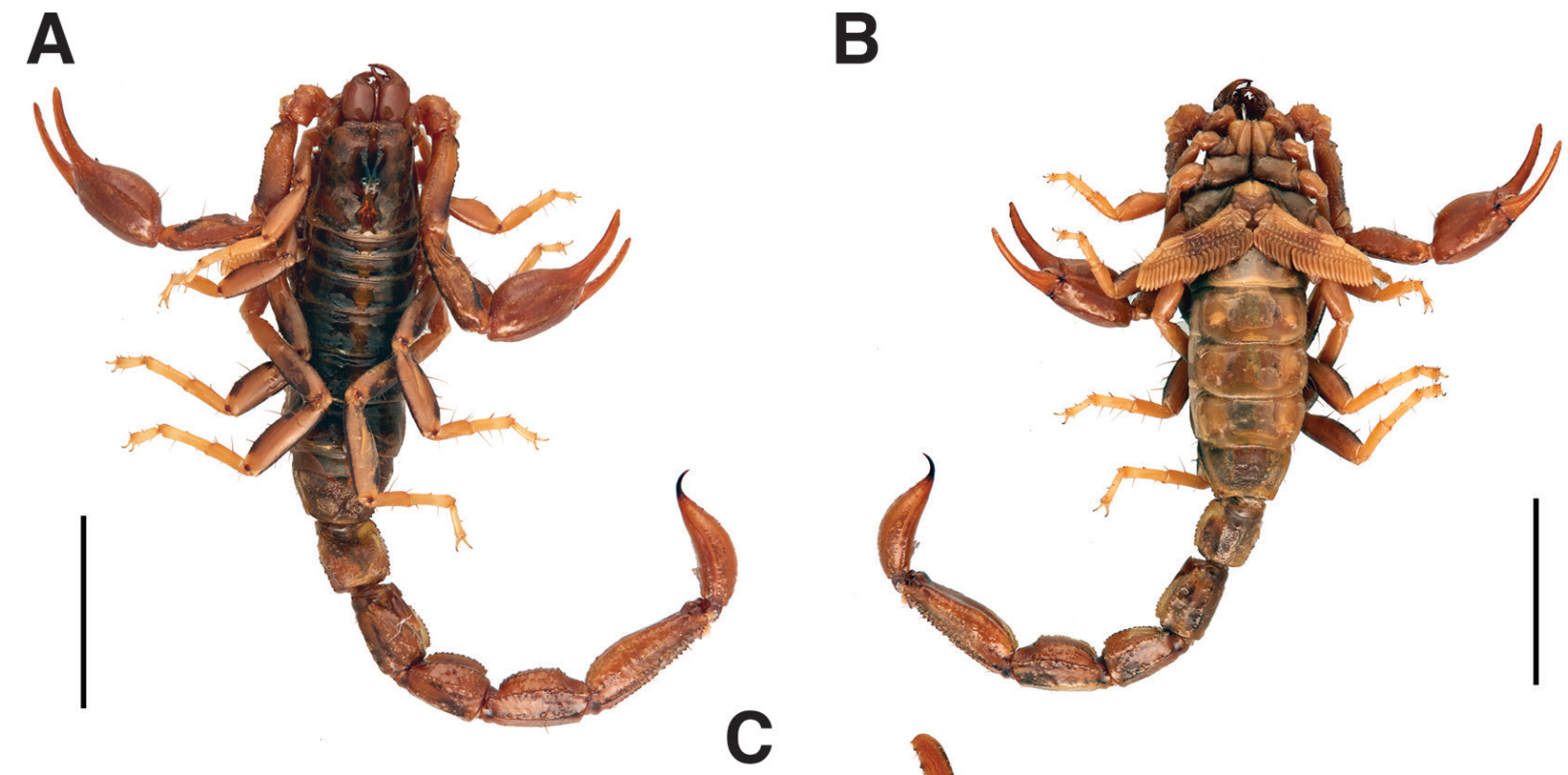

B

D
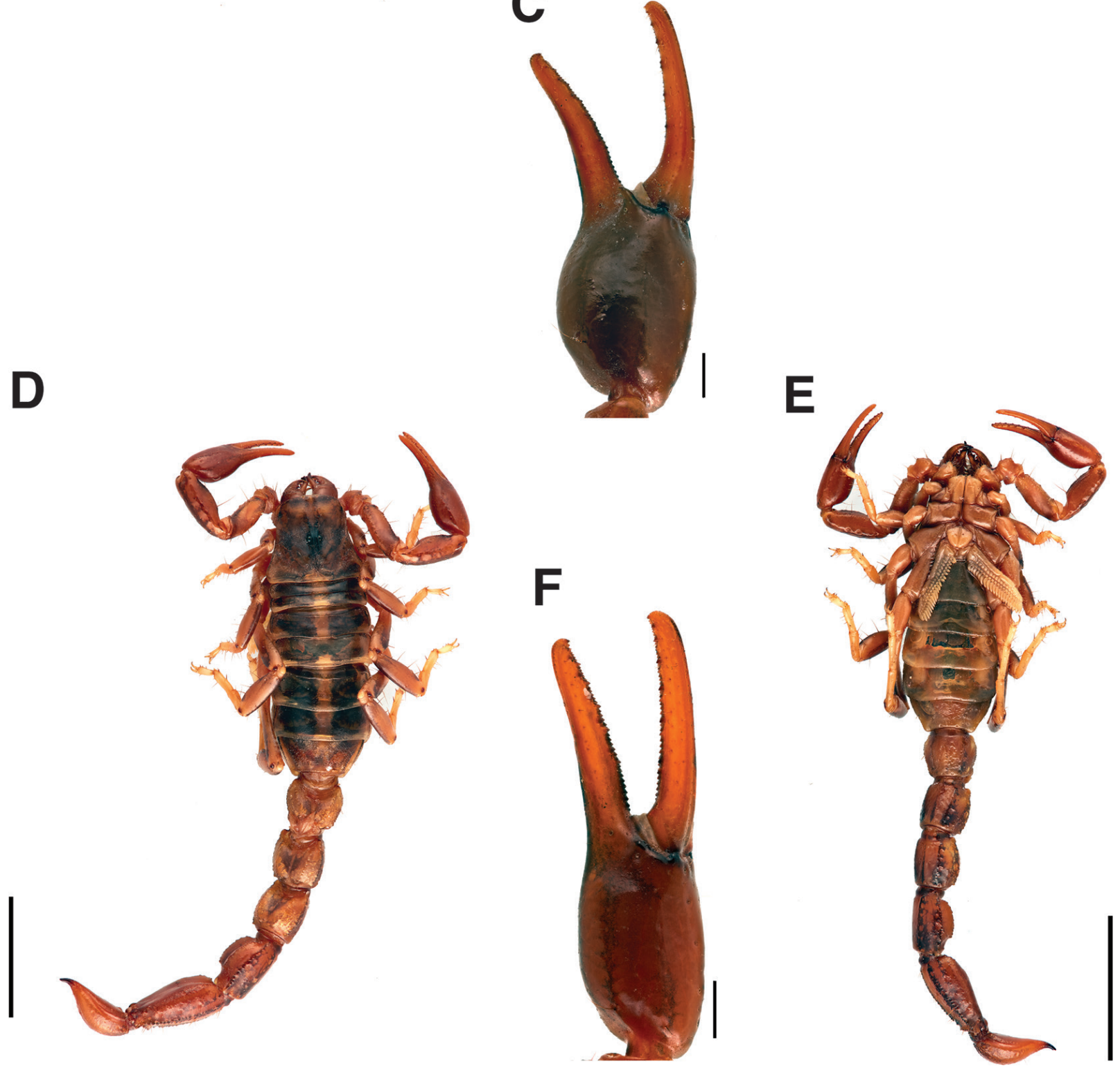

Figure 14. Bothriurus paessleri Kraepelin, 1911 [= Orobothriurus paessleri (Kraepelin, 1911)], male lectotype (A-C), female paralectotype (D-F): A, D dorsal aspect of habitus B, E ventral aspect of habitus $\mathbf{C}, \mathbf{F}$ pro-lateral aspect of chela. Scale bars: $10 \mathrm{~mm}$ (A-B, D-E), $1 \mathrm{~mm}(\mathbf{C}, \mathbf{F})$. 
Schmid (1924-1998) collected in Uttar Pradesh (India) in 1958 (Weaver and Nimmo 1999) but was at the same time working with material collected in Chile by Luis Enrique Peña (Schmid 1958). Peña, a Chilean entomologist, was regularly supplying researchers, museums and collections around the world with arachnid and insect specimens from Chile (Barriga-Tũnon and Ugarte-Peña 1995). He probably collected the present specimen and sent it to the Zoologisches Museum Hamburg. It is plausible that a label of Schmid's field work in India was wrongly placed inside the vial of the scorpion collected by Peña.

\section{Family Chactidae Pocock, 1893}

Type specimens belonging to eight species are present at $\mathrm{ZMH}$. The type of one species was destroyed and the type of a second species is probably lost.

\section{Genus Broteochactas Pocock, 1893}

\section{Broteochactas parvulus}

Fig. 15

Broteochactas parvulus Pocock, 1897b: 364-366

Current combination. Broteochactas parvulus Pocock, 1897

Syntype. + (ZMH-A0001193), [Brazil], Amazonas [Amazon River], [Pará], Santarém [2²6’35”S, 544'30’W], [beneath rotten wood], 06.1897, F. Pickard-Cambridge leg., BMNH don.

Remarks. Pocock (1897b) mentioned several specimens collected by Pickard-Cambridge. The remaining syntypes are deposited in the BMNH (Sissom 2000: 294).

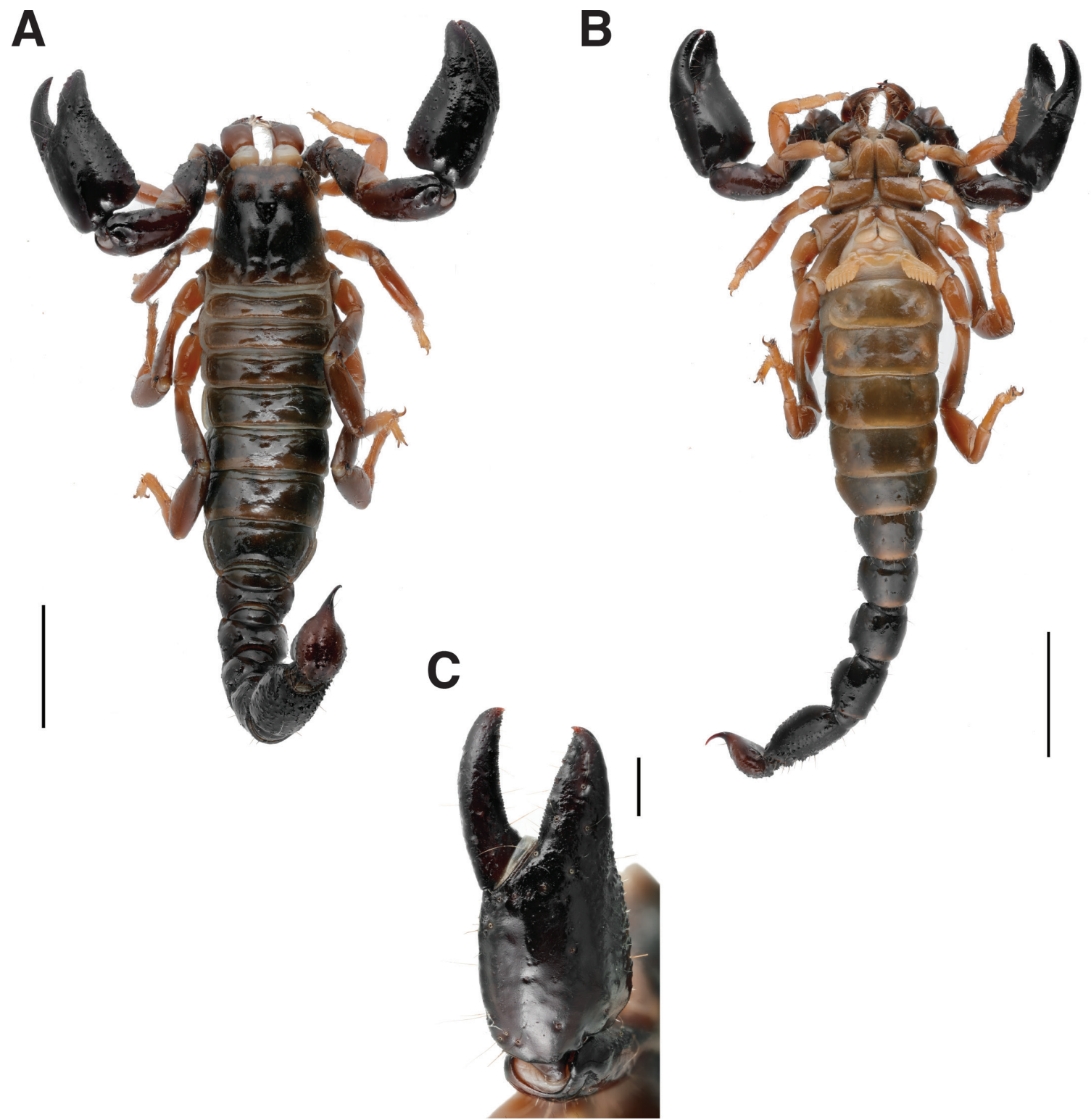

Figure 15. Broteochactas parvulus Pocock, 1897, female syntype, habitus A dorsal aspect B ventral aspect $\mathbf{C}$ retrolateral aspect of chela illustrating dentate margins of fingers. Scale bars: $5 \mathrm{~mm}(\mathbf{A}-\mathbf{B}), 1 \mathrm{~mm}(\mathbf{C})$. 


\section{Genus Chactas Gervais, 1844}

\section{Iomachus exsul}

Iomachus exsul Werner, 1939: 360, fig. 3

Current combination. Chactas exsul (Werner, 1939)

Holotype (lost). Data according to original description: $\widehat{o}$ Costa Rica, [Limón], Ebene von Limon [plains of Puerto Limón], bei Las Mercedes [near Las Mercedes] [10¹0'32'N, 83³6'41'”W], 10-30 m über dem Meere [10-30 m alt.], 12-30 km vom Atlantik [12-30 km from the coast], Siguires, in Bohrlöchern [in boreholes].

Remarks. According to Sissom (2000), the holotype was destroyed during World War II. A neotype was subsequently designated by Francke and Stockwell (1987: 27). This specimen, a female from El Valle (Panama), is deposited in the collection of the Smithsonian Museum in Washington (USNM). We consider the designation of this neotype questionable for the following reasons: (1) The locality of the neotype is about $650 \mathrm{~km}$ from the original type locality; (2) The authors examined only five specimens in total, four females and one juvenile. Among this material, all specimens are from Panama except one female collected in the Limón Province in Costa Rica. It would have been more logical to designate this latter specimen as the neotype rather than one specimen from Panama because the site of collection was closer to the type locality. However, the authors do not provide any explanation regarding their decision to choose a specimen from Panama as neotype.

\section{Scorpio (Chactas) fuchsii \\ Fig. 16 \\ Scorpio (Chactas) fuchsii Berthold, 1846: 60-62}

Current senior synonym. Chactas vanbenedenii (Gervais, 1843) [Synonymized by Kraepelin 1894: 171]

Lectotype. (Fig. 16A-B) ते (ZMH-A0003050), Colombia, [Cauca], Popayán [2²6'17'N, 76³6'47’W], coll. 1893, Museum Göttingen.

Paralectotype. (Fig. 16C-D) $q$ (ZMH-A0003050), same data as holotype

Remarks. A label in the jar mentions "Chactas vanbenedenii (Gervais), Original-Exemplar zu Chactas fuchsii Berthold Kraepelin", confirming that these two specimens are the original series examined by Berthold (1946). The male is designated here as lectotype and the female is a paralectotype.

\section{Chactas lepturus intermedius}

Fig. 17

Chactas lepturus intermedius Kraepelin, 1912b: 64, 67
Current senior synonym. Chactas lepturus Thorell, 1876 [Synonymized by Lourenço 1997h: 84-85]

Lectotype. (Fig. 17A-B) $\circ$ (ZMH-A0003047), Columbien [Colombia], between Boca del Monte and Tambo [near Bogota] [441'28”N, 74²1'11'W], 1900 m, Otto Fuhrmann leg., ded. 10.1911.

Paralectotypes. 2 ㅇ, 1 subadult $\widehat{\partial}$ (Fig. 17C-D), 2 juveniles (ZMH-A0001869), same data as lectotype.

Remarks. Kraepelin (1912b) originally described this taxon as a subspecies of $C$. lepturus and listed the type locality as "Boca del Monte bei Bogota in Kolumbien, Ostkordillere, in 2400 Höhe". Although the altitude is different than the one mentioned on the label, the locality is the same. The present specimens are considered here as types. One female is designated as the lectotype and the others are paralectotypes.

Remarks on collector. Otto Fuhrmann (1871-1945) was a Swiss parasitologist specializing in helminthology (Delachaux and Baer 1914). He travelled to Columbia in 1910 with Eugene Mayor (1876-1976). They stayed in La Camelia (part of the coffee plantation owned by Karl Bimberg, German consul in Medellin, and located south west of Angelopolis) from August to September 1910 and visited Bogota and its surroundings in October 1910 (Fuhrmann and Mayor 1914; see map p. 117).

\section{Chactas lepturus major}

Fig. 18A-B

Chactas lepturus major Kraepelin, 1912b: 67

Current combination. Chactas major Kraepelin, 1912 [elevated to species status by Lourenço 1999: 127]

Holotype. + (ZMH-A0002238), Columbien [Columbia], [Antioquia], La Camelia [6 $6^{\circ} 66^{\prime} 00^{\prime \prime} \mathrm{N}, 75^{\circ} 44^{\prime} 00^{\prime \prime W}$, 1820 m alt., Otto Fuhrmann leg., ded. 10.1911.

Remarks. Kraepelin (1912b) described this taxon as a subspecies of Chactas lepturus (Chactas lepturus major) and reported the type locality as "Angelopolis in Kolombien, Zentralkordillere, in 1890 Höhe; Gundua in Kolombien, Ostkordillere in $950 \mathrm{~m}$ Höhe". The same locality was cited again in a subsequent publication (Kraepelin 1914c). Sissom (2000) mentioned holotype and paratypes but he was not sure whether these specimens were present in the ZMH collection. Only one female is present in the $\mathrm{ZMH}$ collections and its primary data differ from the original description. We cannot exclude a transcription error in museum labels or Kraepelin's original publication and since no other specimens of this species are available, the given specimen is treated as the holotype until more data become available. This specimen morphology is congruent with Kraepelin's definition of C. major (pectinal tooth count $8-8$, body length $56 \mathrm{~mm}$ ) and suitable to diagnose the species.

Remarks on collector. See paragraph on Chactas lepturus intermedius above. 


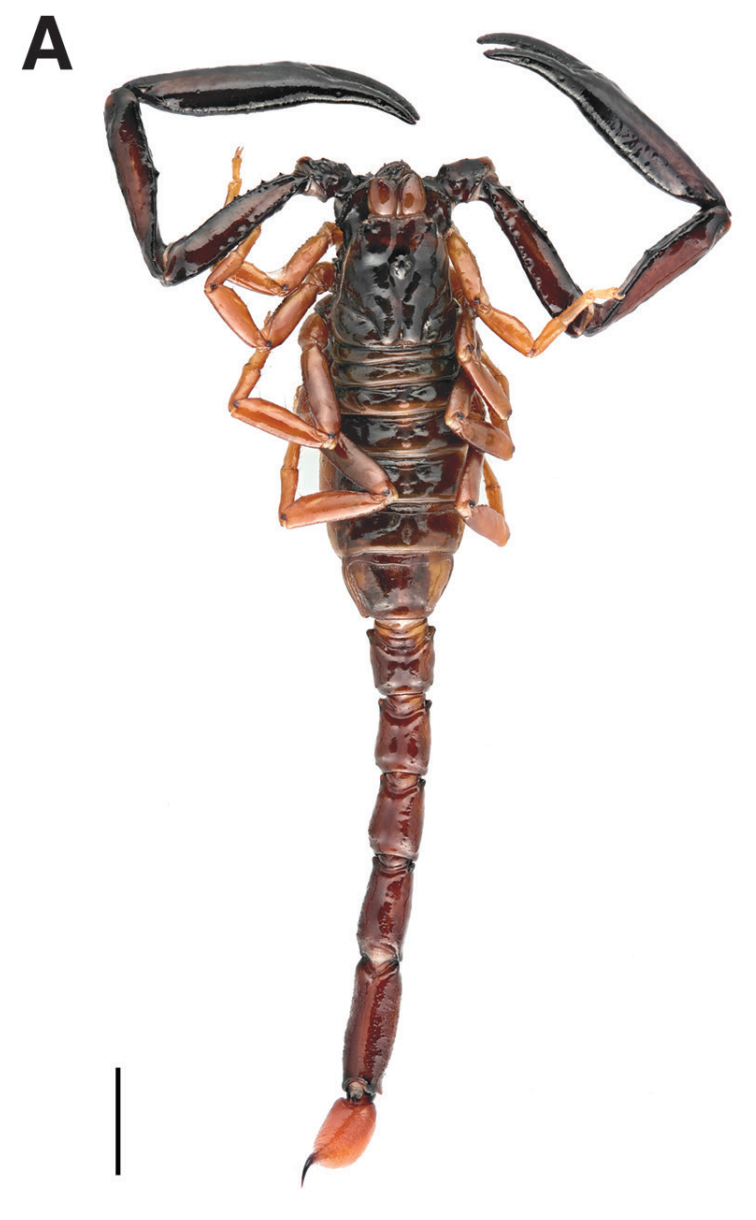

\section{B}

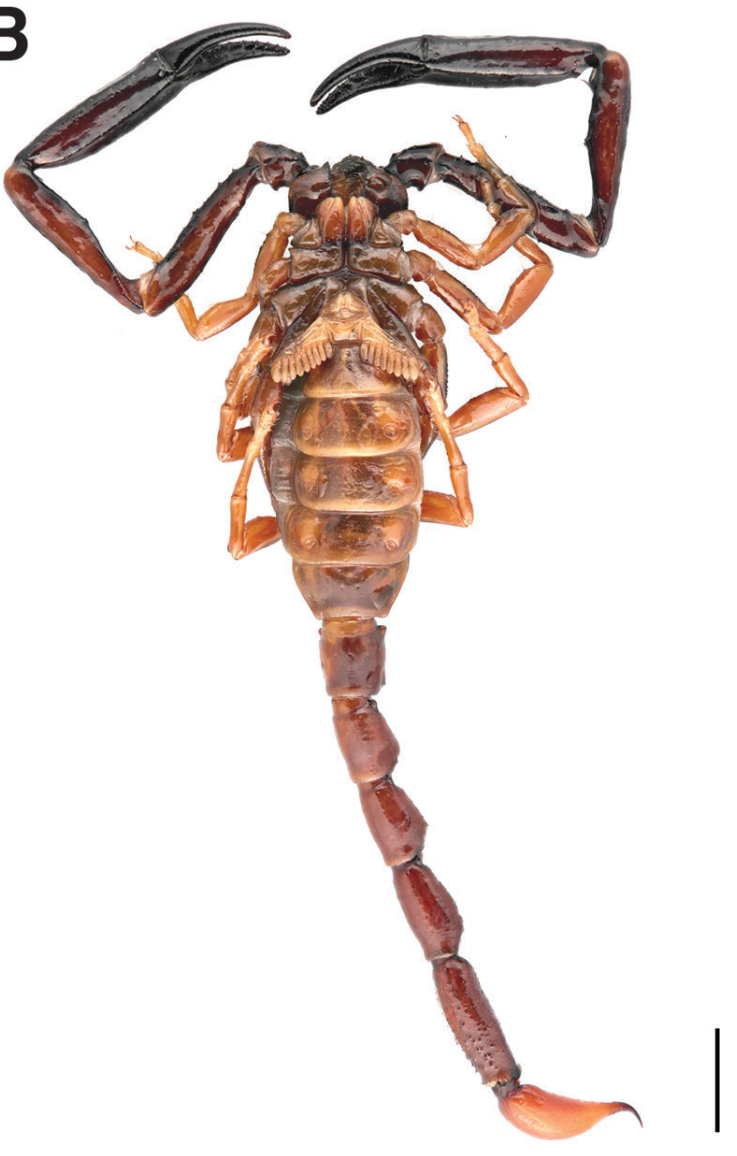

C

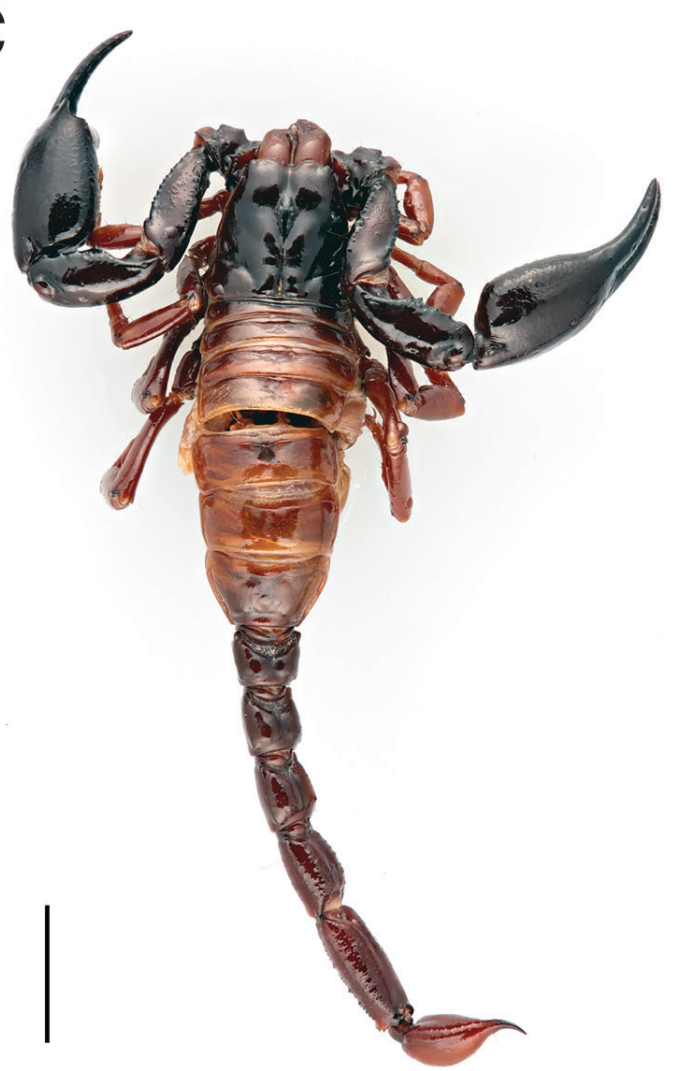

D

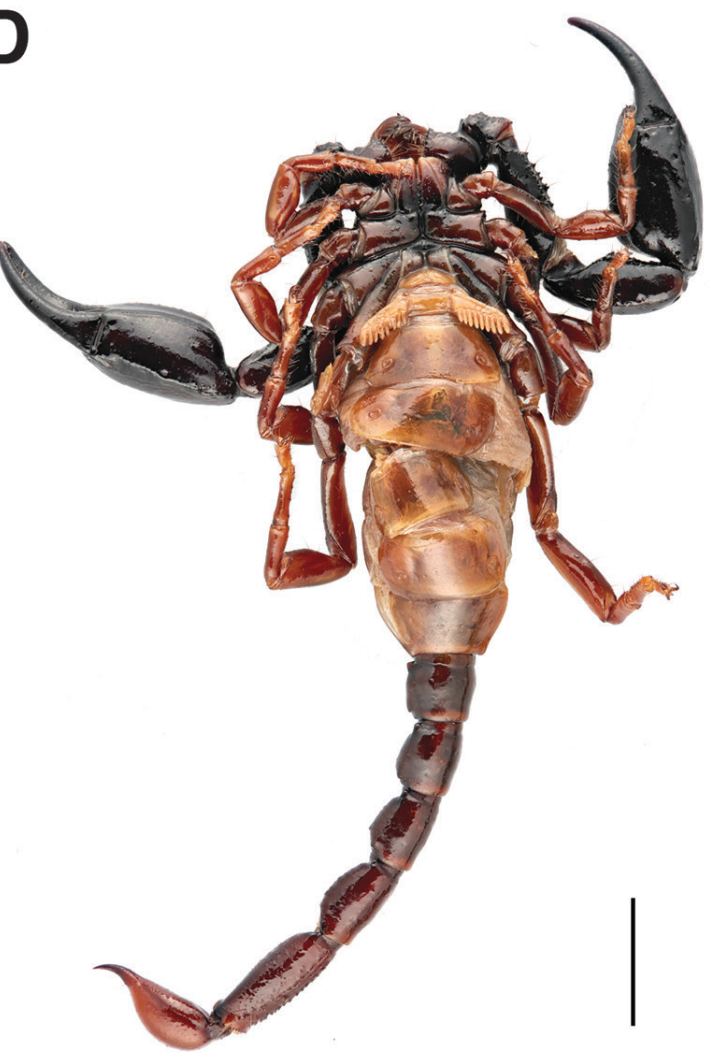

Figure 16. Chactas fuchsii Berthold, 1846 [= Chactas vanbenedenii (Gervais, 1843)], male lectotype (A-B), paralectotype (female) (C-D): A, C dorsal aspect of habitus B, D ventral aspect of habitus. Scale bars: $10 \mathrm{~mm}$. 
A

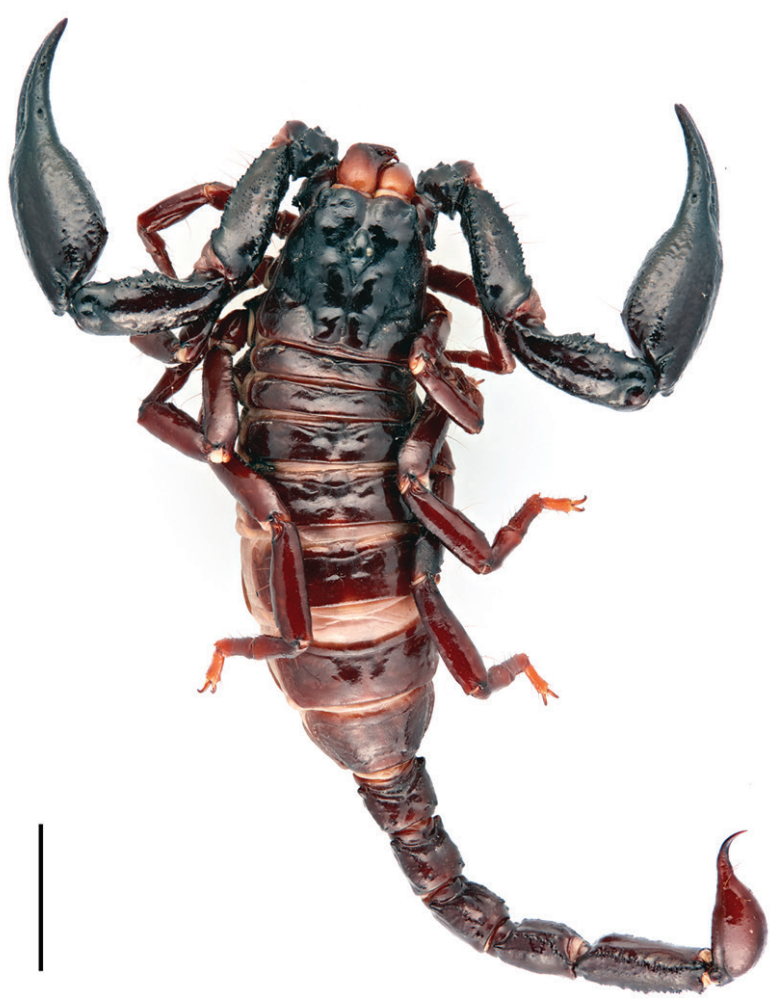

B

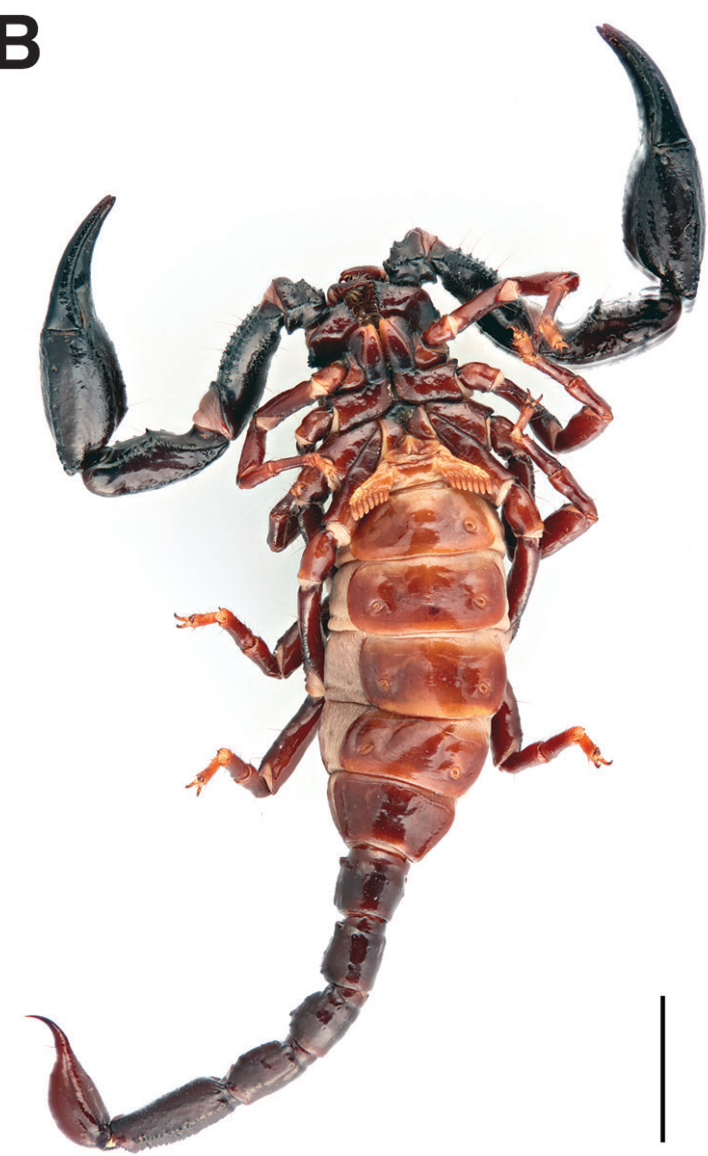

C

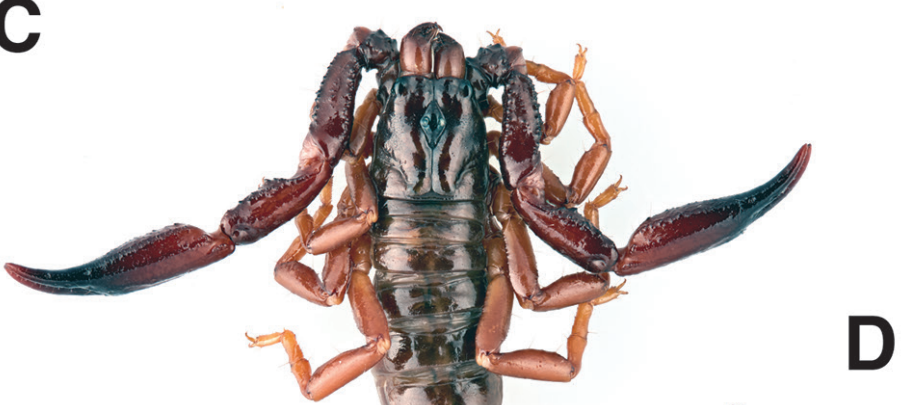

$\mid$
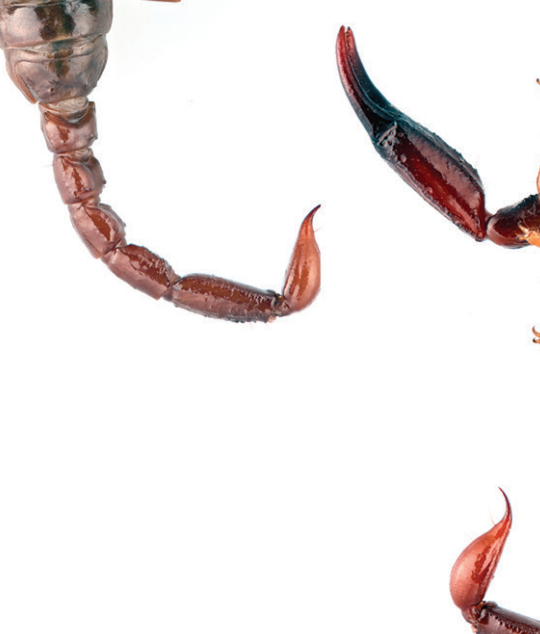

Figure 17. Chactas lepturus intermedius [= Chactas lepturus Thorell, 1876], female lectotype (A-B), subadult male paralectotype (C-D): A, C dorsal aspect of habitus B, D ventral aspect of habitus. Scale bars: $10 \mathrm{~mm}$. 


\section{Chactas ozendai}

Fig. $18 \mathrm{C}-\mathrm{D}$

Chactas ozendai Lourenço, 1999: 127, 129, figs. 8-10

Current combination. Chactas ozendai Lourenço, 1999 [Chactidae]

Holotype. ô (ZMH-A0003359), Columbia, Department of Antioquia, Angelopolis $\left[6^{\circ} 06^{\prime} 41^{\prime \prime} \mathrm{N}\right.$, $75^{\circ} 42^{\prime} 37^{\prime \prime} \mathrm{W}$, in wet forest at high altitude, $1860 \mathrm{~m}$, under a log, 10.01.1987, O. Vilalobos leg., W. R. Lourenço don.

\section{Chactas reticulatus}

Fig. 19

Chactas reticulatus Kraepelin, 1912b: 64-66 [Chactas]

Current combination. Chactas reticulatus Kraepelin, 1912 Lectotype. (Fig. 19A-B) ते (ZMH-A0002124), Columbien [Columbia], [Antioquia], Angelopolis [6 $\left.06^{\prime} 41^{\prime \prime} \mathrm{N}, 75^{\circ} 42^{\prime} 37^{\prime \prime} \mathrm{W}\right], 1820 \mathrm{~m}$ alt., Otto Fuhrmann leg., ded. 10.1911.

Paralectotypes. (Fig. 19C-D) $\subsetneq$ (ZMH-A0002124), same data as lectotype; 1 \&, 1 subadult,+ 1 juvenile (ZMH-A0003048), Columbien [Columbia], [Antioquia], La Camelia [6 $06^{\circ} 00^{\prime} \mathrm{N}, 75^{\circ} 44^{\prime} 00^{\prime \prime} \mathrm{W}$, Otto Fuhrmann leg., 10.1911.

Remarks. Kraepelin (1912b, 1914c) listed the type locality as "Angelopolis in der Zentralcordillere Kolombien, in 1820 Höhe, zusammen with Ch. lepturus major". Accordingly, the lectotype was chosen among the specimens from this locality. The remaining syntypes are designated here as paralectotypes.

Remarks on collector. See paragraph on Chactas lepturus intermedius above.

\section{Chactas setosus}

Fig. 20

Chactas setosus Kraepelin, 1912b: 59-60, 62-64

Current combination. Chactas setosus Kraepelin, 1912 Syntypes. 1 đ (Fig. 20A-B), 1 (Fig. 20C-D, ZMH-A0003049), Venezuela, coll. V.1912, BMNH don.

Remarks. Kraepelin (1912b) listed 13 specimens in the type series and the type locality as "Venezuela (Merida, Chama)". He mentioned that the type material was housed in the British Museum. The two specimens in Hamburg are certainly part of this series. Sissom (2000) also mentioned five males and 13 females in the BMNH, and the two specimens in the ZMH collections.

\section{Genus Teuthraustes Simon, 1878}

\section{Chactas amazonicus}

Fig. $21 \mathrm{~A}-\mathrm{C}$
Current combination. Teuthraustes amazonicus (Simon, 1880)

Syntype. $\widehat{\partial}$ (ZMH-A0002125), Peru, [Loreto], Pevas [3¹9'58’'S, 7149'02”W], [M. Nathan leg.], E. Simon don., ded 12.1911.

Remarks. According to Sissom (2000), three males from the type series are held at the MNHN.

\section{Teuthraustes ohausi}

Fig. 21D-F

Teuthraustes ohausi Kraepelin, 1912b: 77-78

Current combination. Teuthraustes ohausi Kraepelin, 1912

Holotype. $\bigcirc$ (ZMH-A0003060), Ecuador, [Loja], Catamayo [3॰59'11"S, 79²1'32”W], 15.12.1902, Friedrich Ohaus leg.

Remarks on collector. Friedrich Ohaus (1864-1946) was a renowned entomologist who published more than 170 publications on beetles (Strube 2009). Although he was trained and worked as a medical doctor, he has held the interim administration of the Natural History Museum in Mainz in 1923-1924, and again in 1941 until his death in 1946. He joined several expeditions to South America as a ship's doctor which allowed him to amass extensive material for his research (Nissen 1952). He visited Brazil (especially Petropolis) from August 1898 to March 1899, Ecuador from August 1904 to April 1906 (travelling over the Cordilleras from Rio Villano to Cururay and Napo to Iquitos and then down the Amazon to Para), and Brazil again in 1926 (São Paulo, Porto Epitacio, Itatiya). The collection date mentioned on the label (1902) is not congruent with the recorded dates of his trip to Ecuador and may be a lapsus.

\section{Heterochactas wittii}

Fig. 22

Heterochactas wittii Kraepelin, 1896b: 141-144, fig. 23-25

Current combination. Teuthraustes witti (Kraepelin, 1896)

Lectotype. (Fig. 22A-C) $\widehat{~(Z M H-A 0002182), ~}$ Ecuador, Province Loja, Piscobamba [4¹4'47'S, 79¹7'56”W], 1893, Ernesto Witt leg., Walter, ded. 10.12.1895.

Paralectotypes. $1 \hat{\sigma}, 1 \propto$ (Fig. 22D-F), 1 subadult $\hat{\sigma}$, 1 juvenile (ZMH-A0001870), same data as lectotype.

Remarks. One male is designated as lectotype, the remaining specimens are paralectotypes.

\section{Family Diplocentridae Karsch, 1880}

One type specimen is present at $\mathrm{ZMH}$. 
A

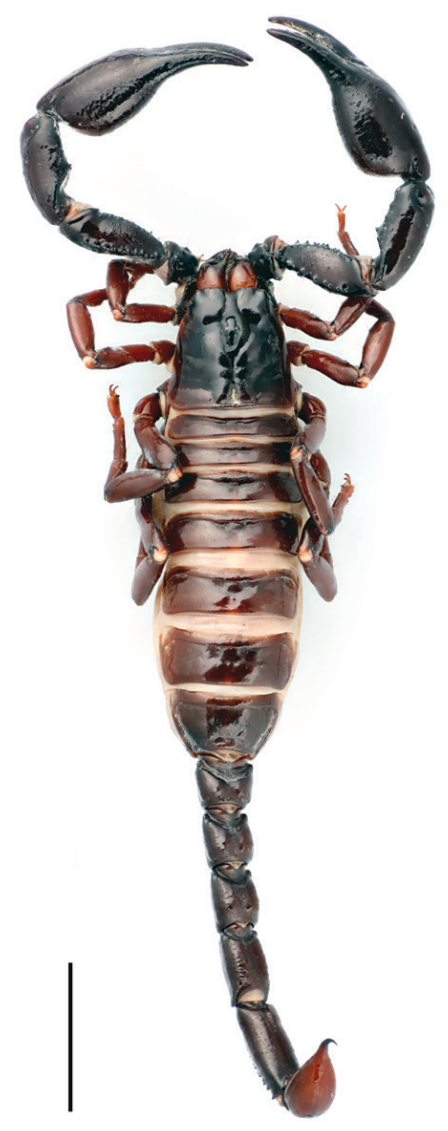

B

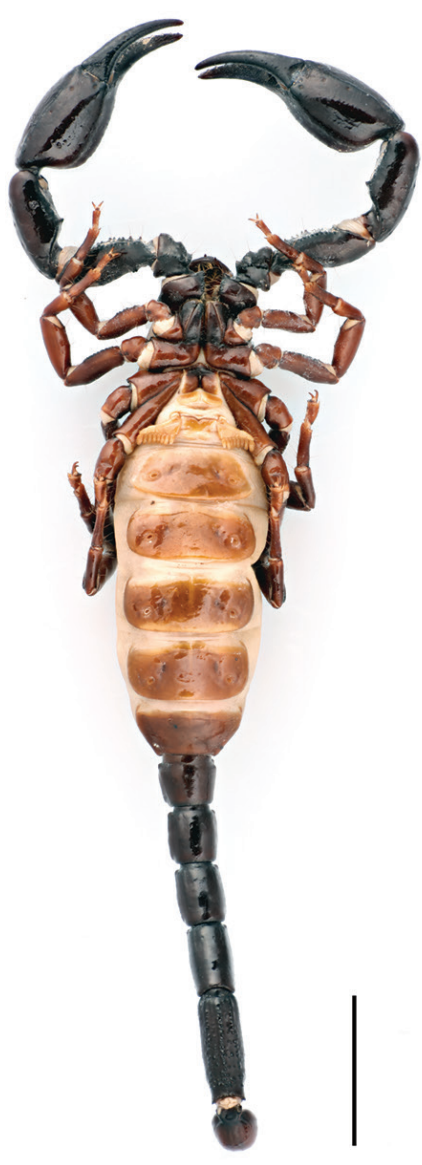

C
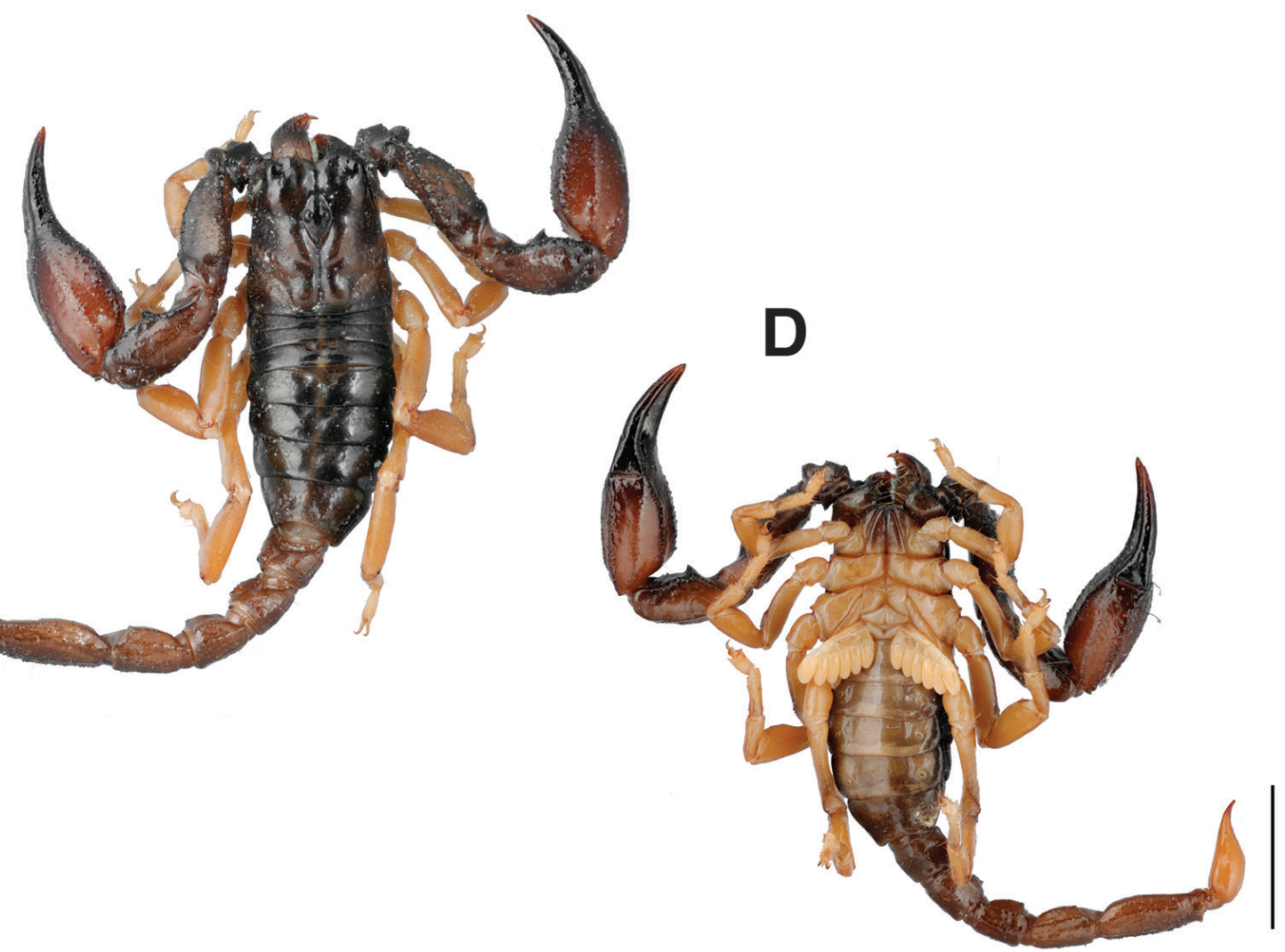

Figure 18. Chactas lepturus major Kraepelin, 1912, female holotype (A-B) [= Chactas major Kraepelin, 1912]. Chactas ozendai Lourenço, 1999, male holotype (C-D): A, C dorsal aspect of habitus B, D ventral aspect of habitus. Scale bars: $1 \mathrm{~mm}$. 


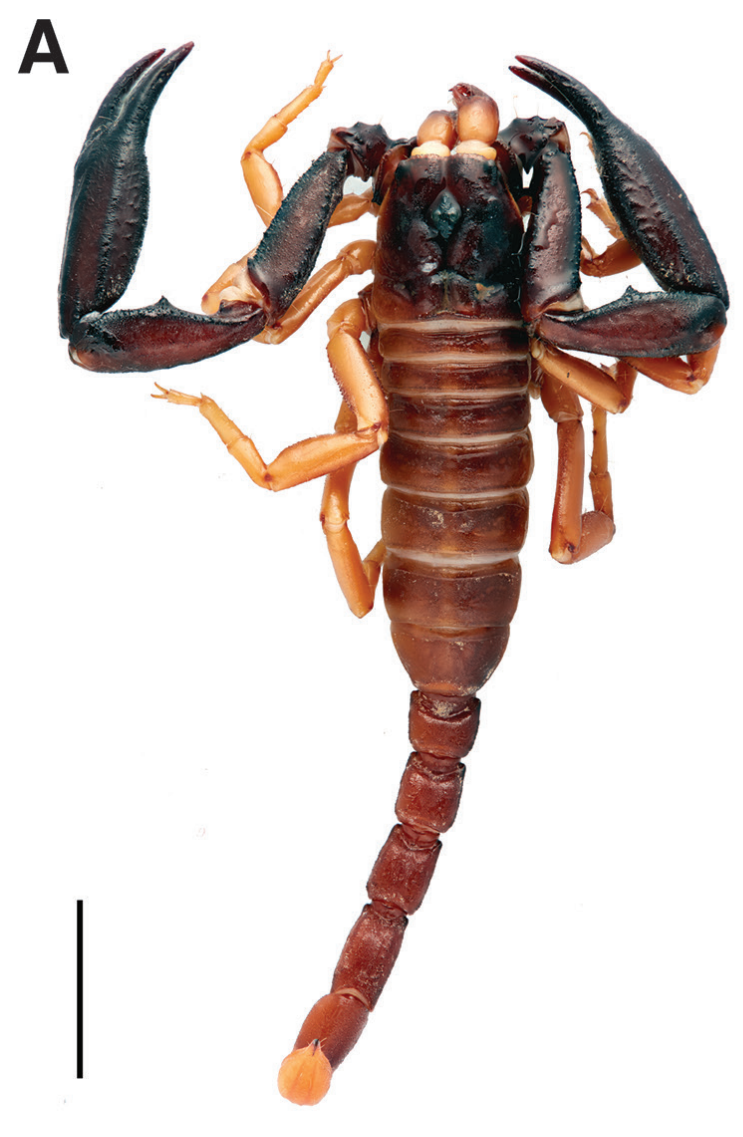

B

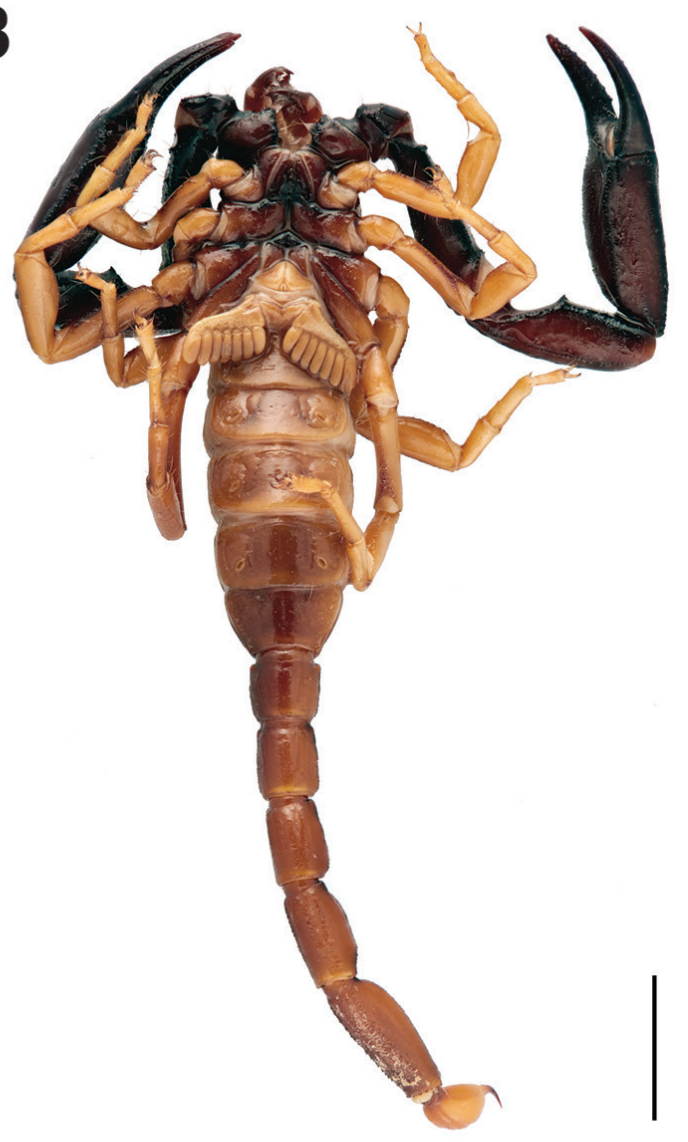

C
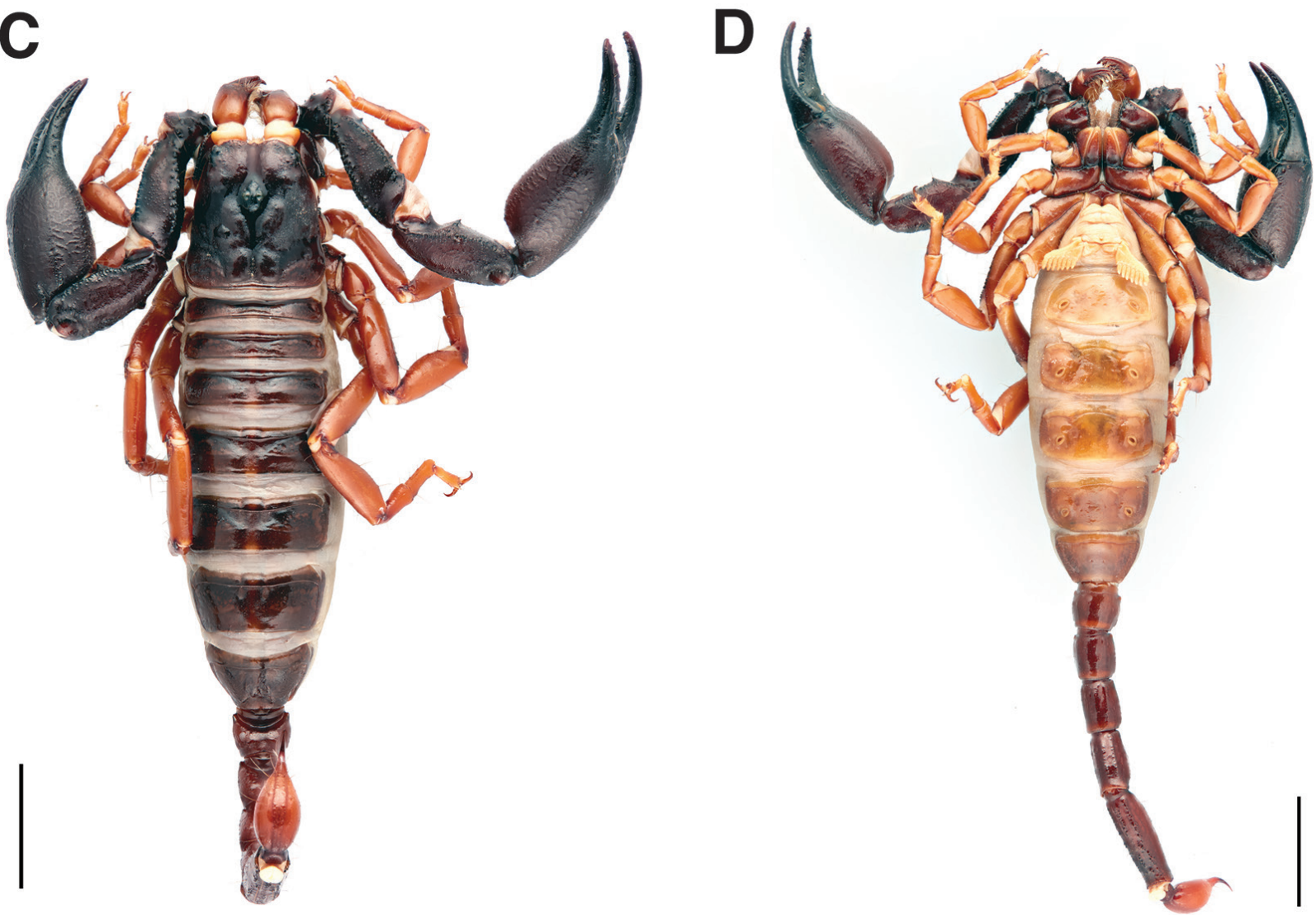

Figure 19. Chactas reticulatus Kraepelin, 1912, male lectotype (A-B), female paralectotype (C-D): A, C dorsal aspect of habitus B, D ventral aspect of habitus. Scale bars: $10 \mathrm{~mm}$. 

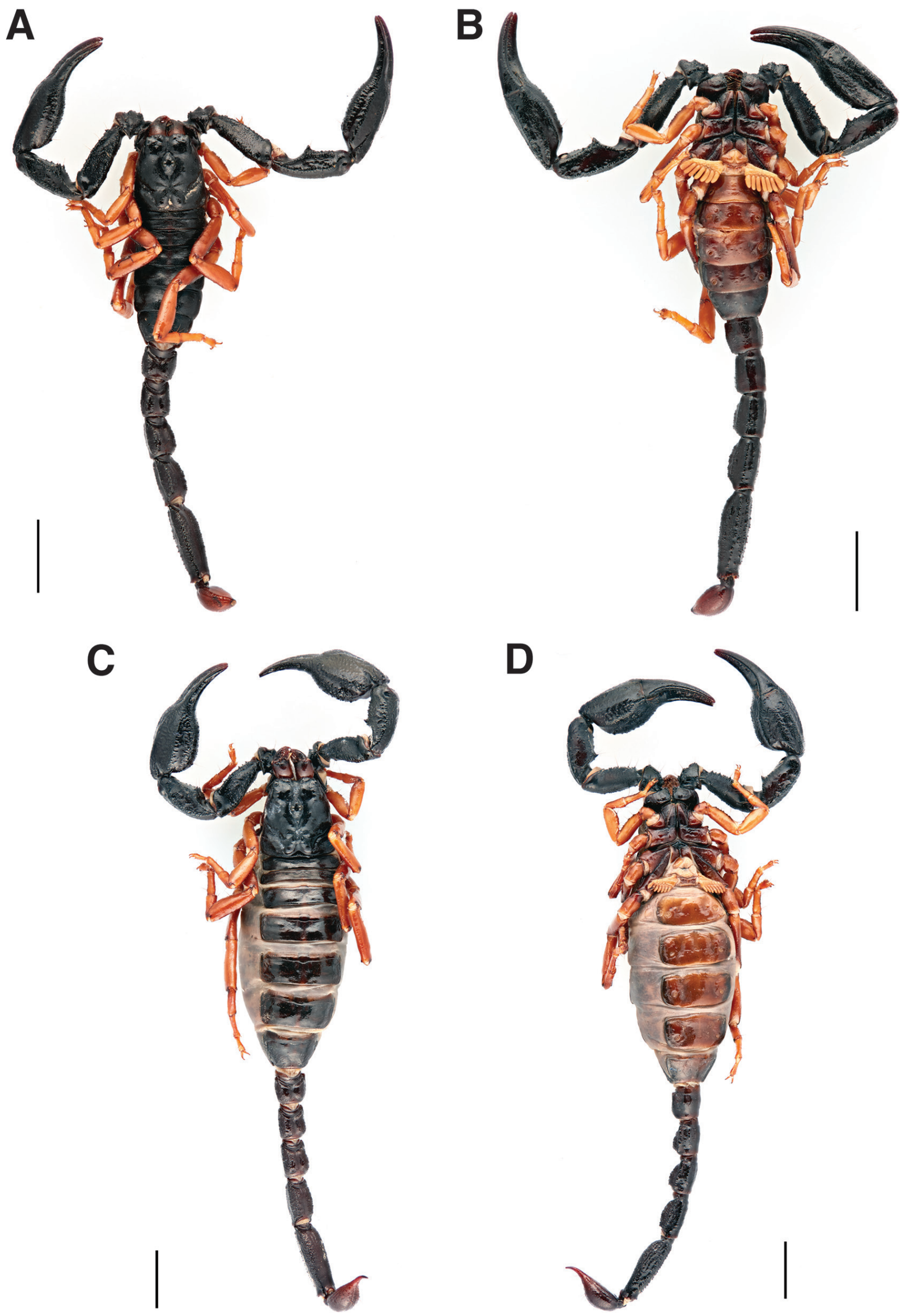

Figure 20. Chactas setosus Kraepelin, 1912, male syntype (A-B), female syntype (C-D): A, C dorsal aspect of habitus B, D ventral aspect of habitus. Scale bars: $10 \mathrm{~mm}$. 
A

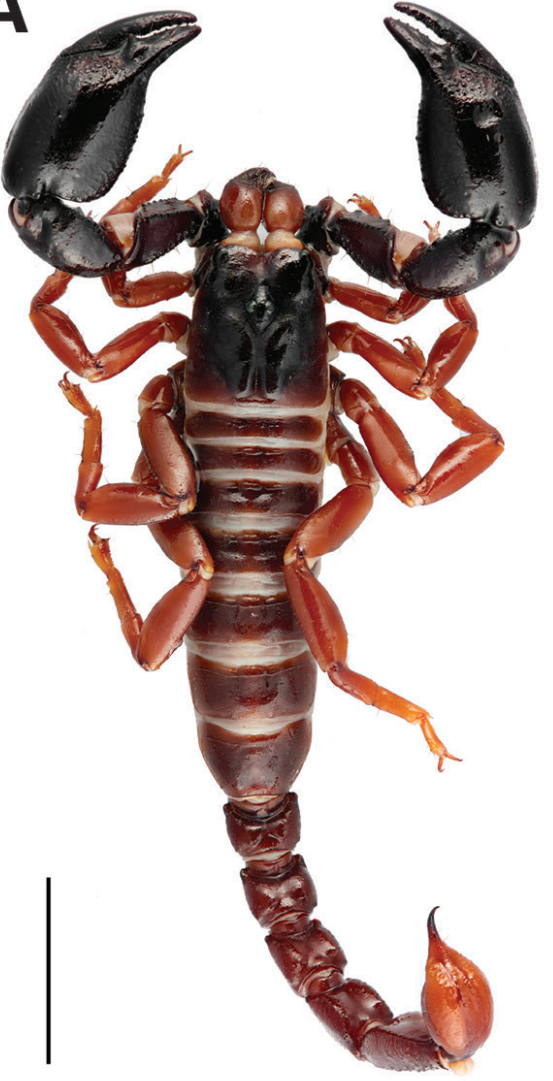

D

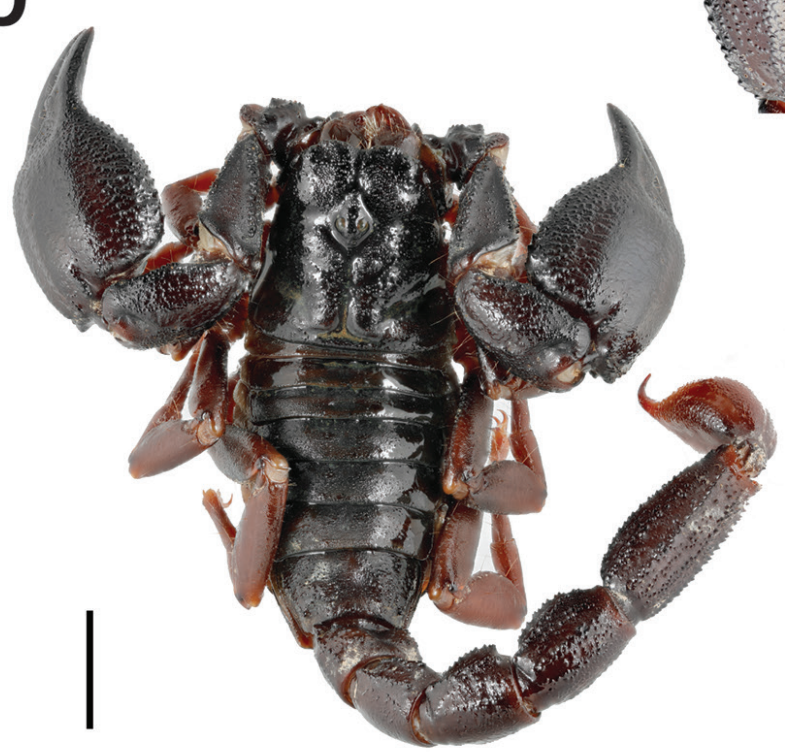

C

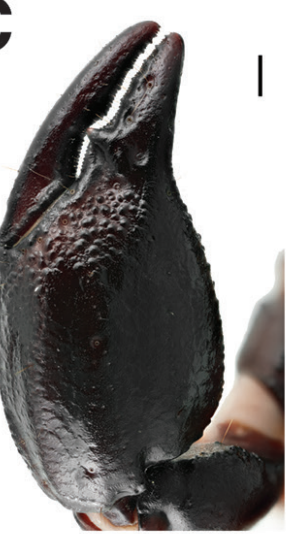

E

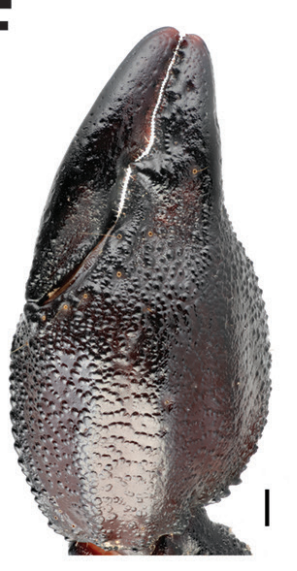

B

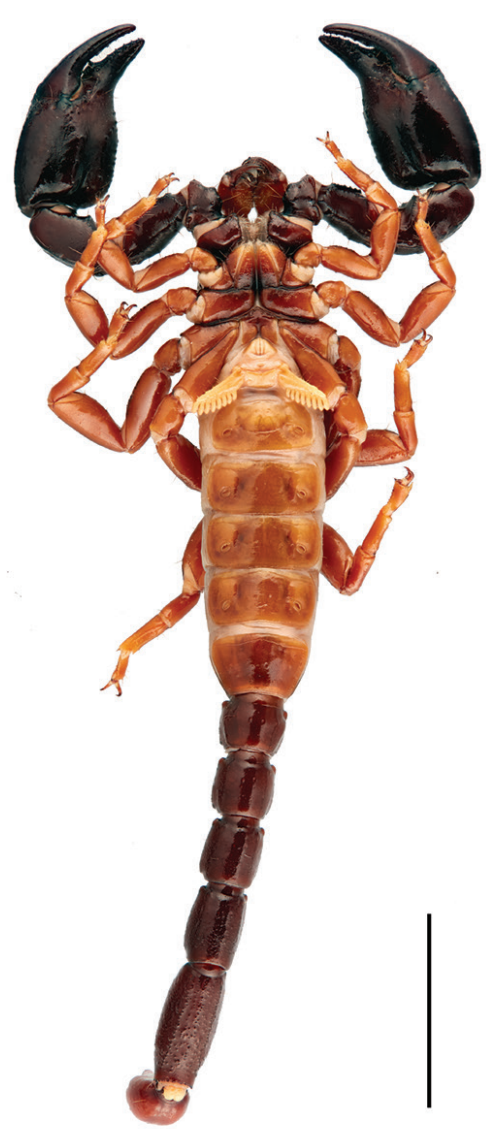

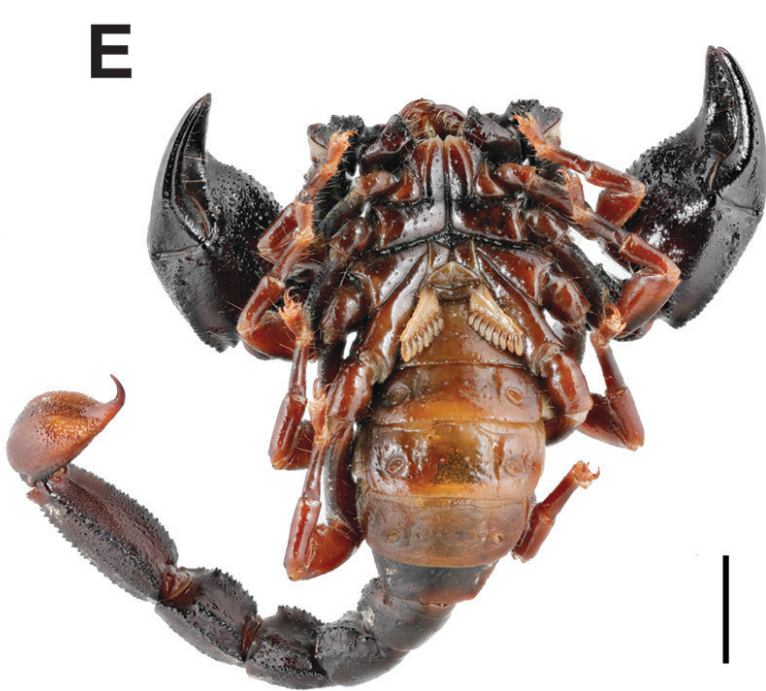

Figure 21. Chactas amazonicus Simon, 1880 [= Teuthraustes amazonicus (Simon, 1880)], male syntype (A-C). Teuthraustes ohausi Kraepelin, 1912, male holotype (D-F): A, D dorsal aspect of habitus B, $\mathbf{E}$ ventral aspect of habitus $\mathbf{C}$, F retrolateral aspect of chela illustrating dentate margins of fingers. Scale bars: $10 \mathrm{~mm}(\mathbf{A}-\mathbf{B}), 5 \mathrm{~mm}(\mathbf{D}-\mathbf{E}), 1 \mathrm{~mm}(\mathbf{C}, \mathbf{F})$. 
A

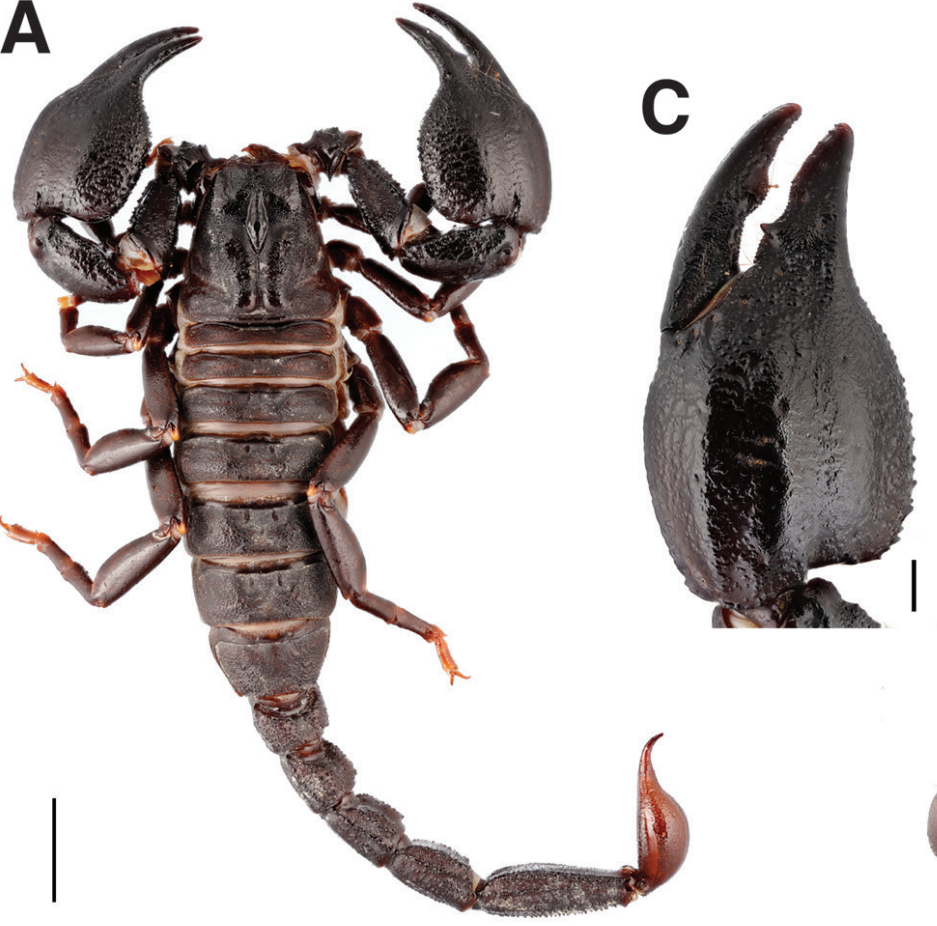

$\mathbf{F}$

D

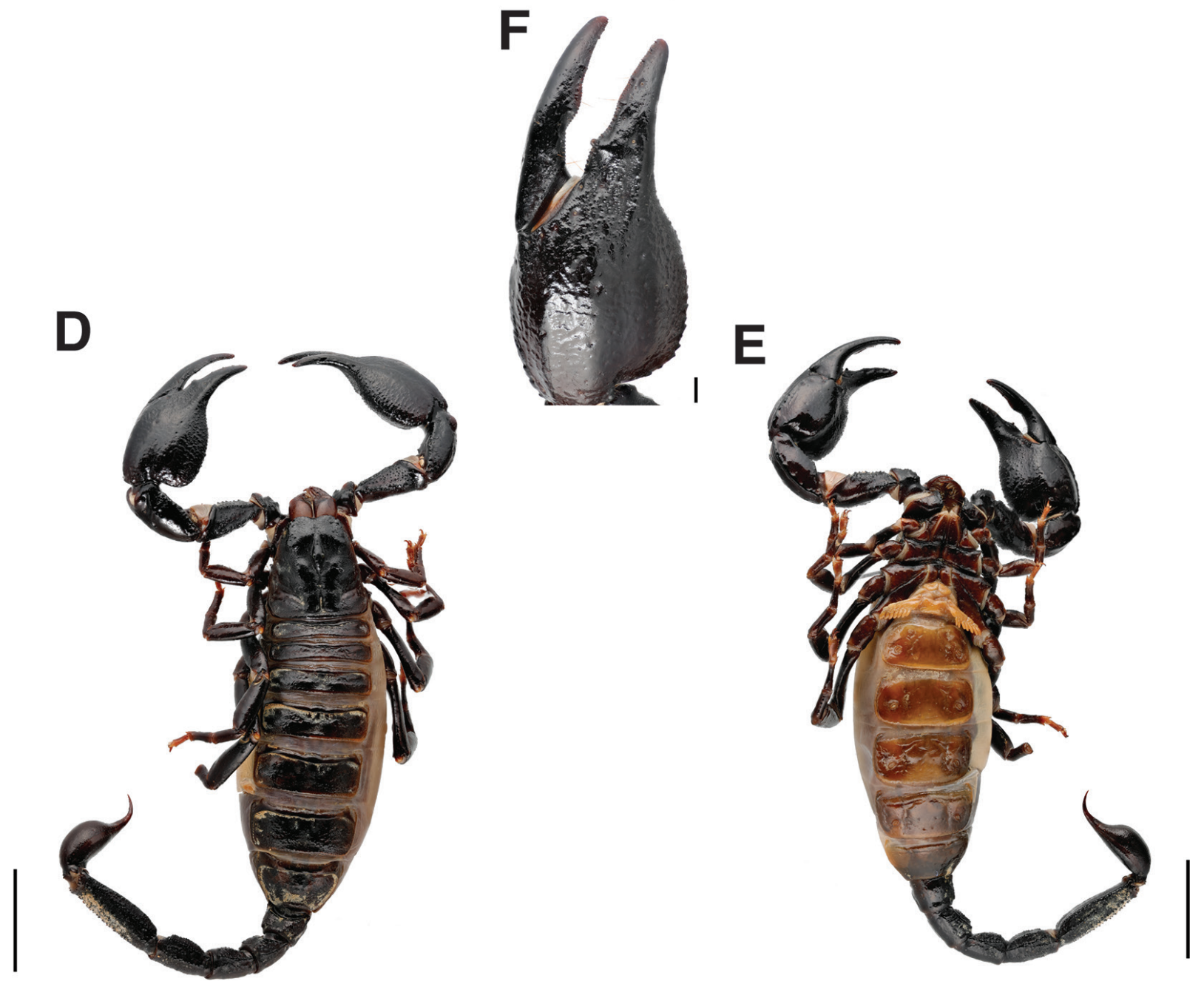

B

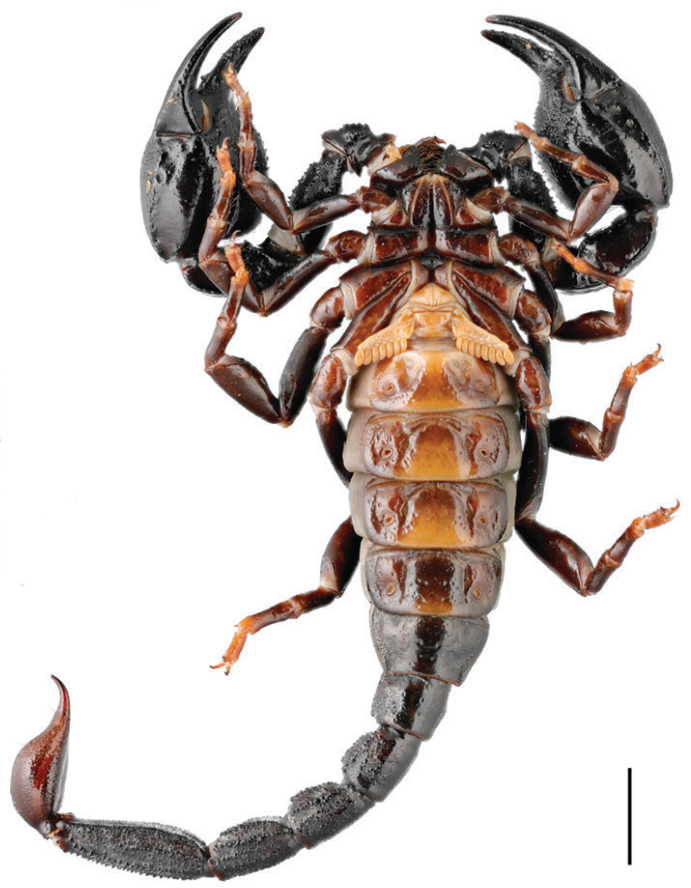

Figure 22. Heterochactas wittii Kraepelin, 1896 [= Teuthraustes witti (Kraepelin, 1896)], male lectotype (A-C), female paralectotype (D-F): A, D dorsal aspect of habitus $\mathbf{B}, \mathbf{E}$ ventral aspect of habitus $\mathbf{C}, \mathbf{F}$ retrolateral aspect of chela illustrating dentate margins of fingers. Scale bars: $10 \mathrm{~mm}(\mathbf{D}-\mathbf{E}), 5 \mathrm{~mm}(\mathbf{A}-\mathbf{B}, \mathbf{F}), 1 \mathrm{~mm}(\mathbf{C})$. 
Genus Didymocentrus Kraepelin, 1905

\section{Diplocentrus hasethi}

Fig. 23

Diplocentrus hasethi Kraepelin, 1896b: 130-131, fig. 11

Current combination. Didymocentrus hasethi (Kraepelin, 1896)

Holotype. + (ZMH-A0001201), Curaçao [12¹0'54”N, 6859'32’W], C. G. de Haseth leg., ded. 4.10.1895.

Remarks. Francke (1978: 13) transfered Diplocentrus hasethi to the genus Didymocentrus.

Remarks on collector. C. G. de Haseth also collected insects, spiders, millipedes and crabs from Curaçao that he sent to the Hamburg Museum (Kraepelin 1909: IV).

\section{Family Hemiscorpiidae Pocock, 1893}

Type specimens belonging to three species are present at $\mathrm{ZMH}$.

\section{Genus Hemiscorpius Peters, 1861}

\section{Hemiscorpius lepturus}

Fig. 24

Hemiscorpius lepturus Peters, 1861a: 426-427

Current combination. Hemiscorpius lepturus Peters, 1861

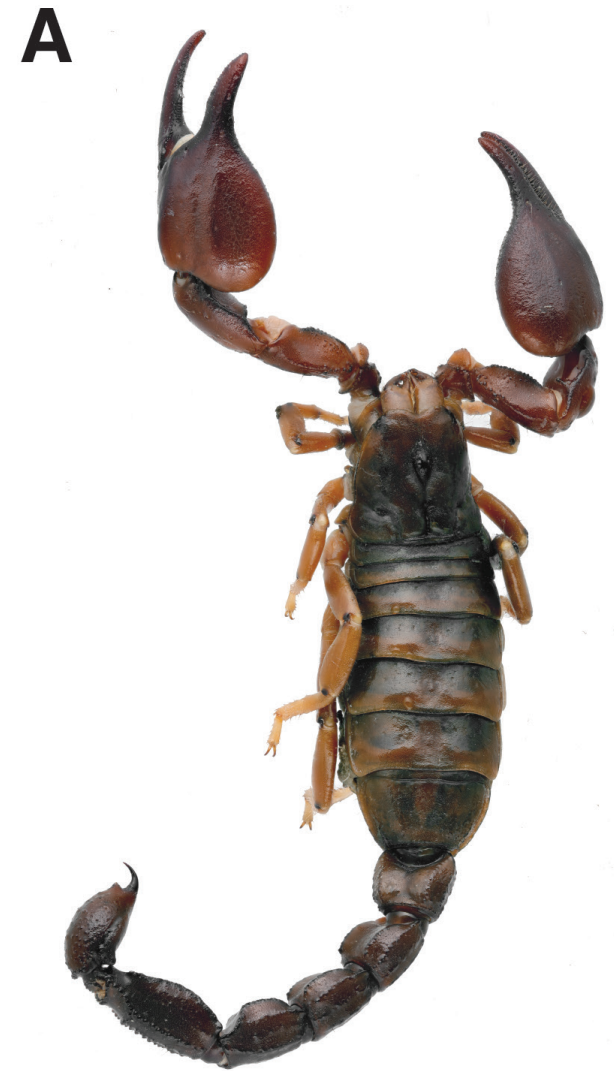

Syntypes. 1 के (Fig. 24A-B, 2321), 1 ㅇ (Fig. 24CD, 2322) (ZMH-A000894), Irak, [Mendeli], Baghdad [3320'26”N, 44²4’03”E], 1893 [Peterman leg.], Wilhelm Peters don. (ZMB).

Remarks. Peters (1861a) described the genus Hemiscorpius. The first time the nominal species is cited in the text, it is incorrectly spelled as Hemiscorpion lepturus but we follow the modified spelling. Four syntypes (ZMB/ Arach-43, two males, two females) are lodged in the ZMB collections.

\section{Hemiscorpius maindroni}

Fig. 25A-B

Hemiscorpius maindroni Kraepelin, 1900: 16

Current combination. Hemiscorpius maindroni Kraepelin, 1900

Syntypes. 1 (Fig. 25A-B), 1 , 2 subadult $\hat{\jmath}, 2$ juveniles (ZMH-A000944), Oman, Mascat [Muscat]

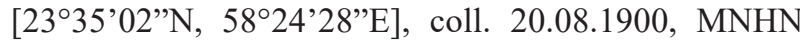
(Paris) don.

Remarks. Many additional syntypes are present in the MNHN collections. A lectotype may be chosen from this series as part of a future taxonomic review.

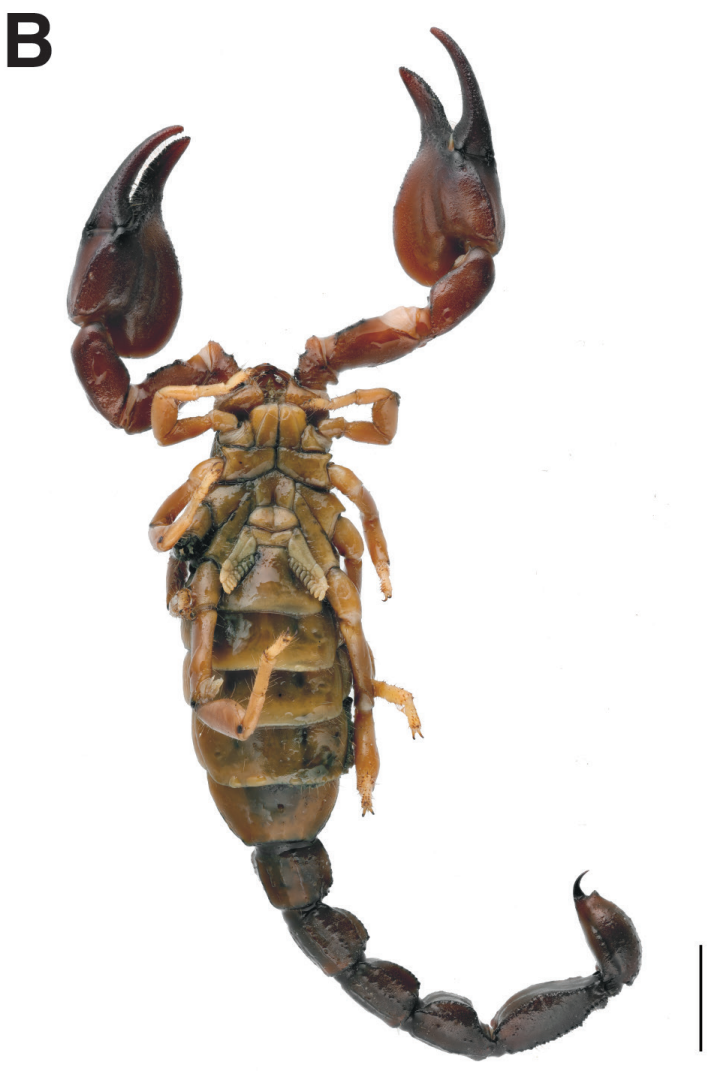

Figure 23. Diplocentrus hasethi Kraepelin, 1896 [= Didymocentrus hasethi (Kraepelin, 1896)], female holotype A dorsal aspect of habitus B ventral aspect of habitus. Scale bars: $10 \mathrm{~mm}$. 

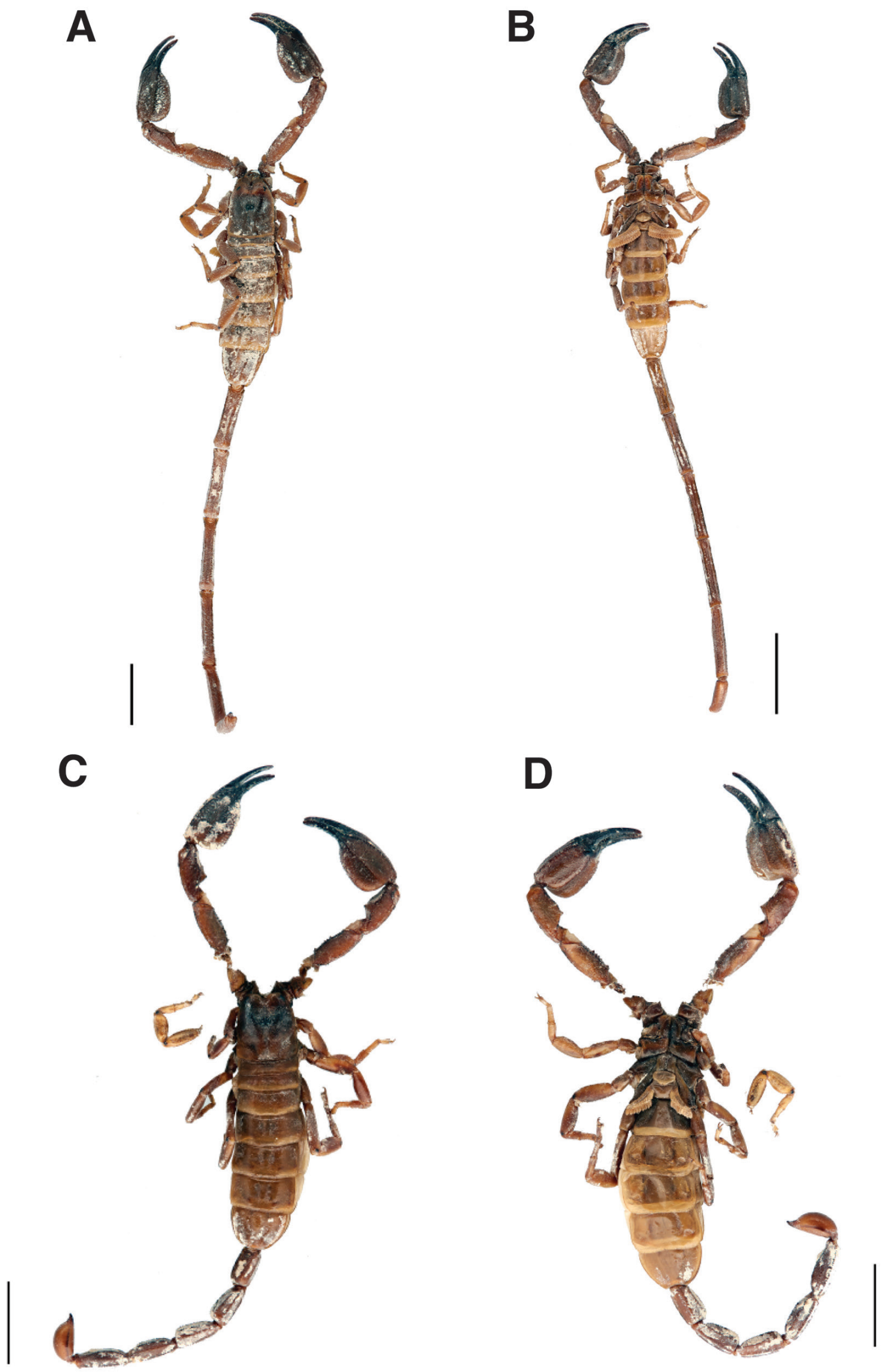

Figure 24. Hemiscorpius lepturus Peters, 1861, male syntype (A-B), female syntype (C-D): A, C dorsal aspect of habitus B, D ventral aspect of habitus. Scale bars: $10 \mathrm{~mm}$. 


\section{Hemiscorpius somalicus}

Fig. 25C-D

Hemiscorpius somalicus Lourenço, 2011: 279-283, fig. $2-4,6-13$

Current combination. Hemiscorpius somalicus Lourenço, 2011

Holotype. $\widehat{ð}$ (ZMH-A0001067), Somalia, [Bari], $5 \mathrm{~km}$ E of Meleden [Meeladeen] [10²5'59'N, 4948'38'E] Road to Scusciuban, IV.1982, P. M. Brignoli leg.

\section{Family Heteroscorpionidae Kraepelin, 1905}

Type specimens belonging to two species are present at $\mathrm{ZMH}$.

\section{Genus Heteroscorpion Birula, 1903}

\section{Heteroscorpion kaii}

Heteroscorpion kaii Lourenço \& Goodman, 2009: 116122, fig. 1-8 (illustration of habitus: 117)

Current combination. Heteroscorpion kaii Lourenço \& Goodman, 2009

Holotype. $q$ (ZMH-A0002239), Madagascar, Toliara Province, Fort Dauphin Region, Grande Lavasoa (= Forêt de Lavasoa) (Tolagnora), estimated at $25.0833^{\circ} \mathrm{S}$, 46.7417 ${ }^{\circ}$ E, 29.XI.2006, under bark, Kai Schütte leg. (ZMH Eing. Nr. A11/09).

\section{Hadogenes opisthacanthoides}

Fig. 26

Hadogenes opisthacanthoides Kraepelin, 1896b: 136-138, fig. $16-18$

Current combination. Heteroscorpion opisthacanthoides (Kraepelin, 1896)

Lectotype.(Fig. 26C-D) juvenile ${ }^{\lambda}$ (ZMH-A0001069), NE Madagascar [North-East Madagascar], Nossi Comba [Nosy Komba] [1327'43”S, 48 20'54”E], Paul Frey leg., ded. 27.09.1895.

Paralectotype. (Fig. 26A-B) + (ZMH-A0001069), same as lectotype

Remarks. Fet et al. (2000) listed the juvenile male as holotype and the female as the paratype. However no specimen is clearly designated as the holotype in the original description. For reasons given above (see paragraph on Bothriurus burmeisteri Kraepelin, 1894), the male must be considered as lectotype and the female is a paralectotype.

Remarks on collector. Some general information about the travel and collecting made by Paul Frey in Madagascar are given in Brancsik (1893)

\section{Family Hormuridae Laurie, 1896}

Type specimens belonging to 21 species are present at $\mathrm{ZMH}$. A species with specimens previously considered as types is also reported here.

\section{Genus Cheloctonus Pocock, 1892}

\section{Cheloctonus glaber}

Fig. 27A-C

Cheloctonus glaber Kraepelin, 1896b: 134-136, fig. 8

Current combination. Cheloctonus glaber Kraepelin, 1896

Lectotype. (Fig. 27A-C) 우 (ZMH-A0000937), Deutsch SW Africa [Namibia], O. Schneider leg., ded. 04.07.1896.

Paralectotypes. 1 subadult $\uparrow, 2$ juveniles (ZMH-A0003127), same data as lectotype.

Remarks. Kraepelin (1896b: 135) mentioned 6 specimens (male and female) in the original description. He also pointed out that the species was collected in sympatry with the buthid Uroplectes triangulifer (Thorell, 1876). Only three specimens are currently registered in the $\mathrm{ZMH}$ collection and the status of the remaining specimens is unknown. They are also not present in the ZMB collections where some of Kraepelin's types are deposited. The adult female is designated here as the lectotype and the remaining specimens are paralectotypes.

\section{Genus Hadogenes Kraepelin, 1894}

\section{Ischnurus troglodytes}

Fig. 27D-F

Ischnurus troglodytes Peters, 1861: 513

Current combination. Hadogenes troglodytes (Peters, 1861)

Syntype. + (ZMH-A0000919), Mozambique, [Tete Province], Tette [Tete] [1609'23"S, 33'35'12"E], X.1913, ZMB don.

Remarks. According to Peters original description, the type series comprises several specimens, both males and females. The specimen present at $\mathrm{ZMH}$ was donated by the Berlin Museum. Accordingly, the major part of the syntype series is currently located in the ZMB collection and comprises seven specimens: 2 juveniles (ZMB/ Arach-44), 1 female (ZMB/Arach-2311), 1 male (ZMB/ Arach-2313), 1 female (ZMB/Arach-2314), 1 female (ZMB/Arach-2315), and 1 juvenile (ZMB/Arach-2316).

\section{Genus Hormurus Thorell, 1876}

\section{Hormurus boholiensis}

Fig. 28A-B

Hormurus boholiensis Kraepelin, 1914d: 333 


\section{A}

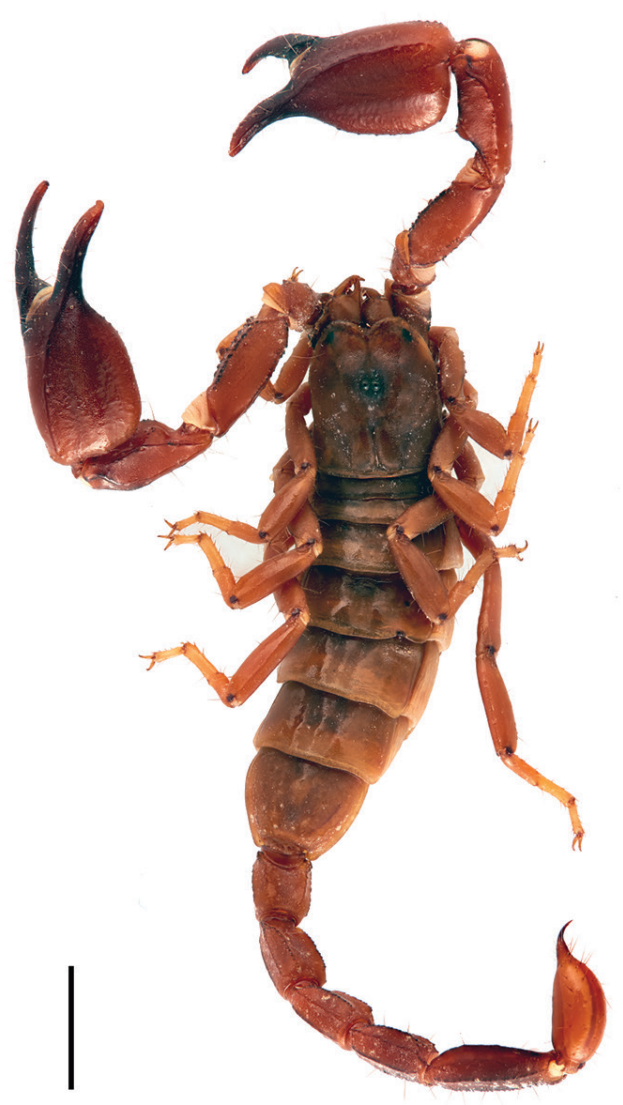

C

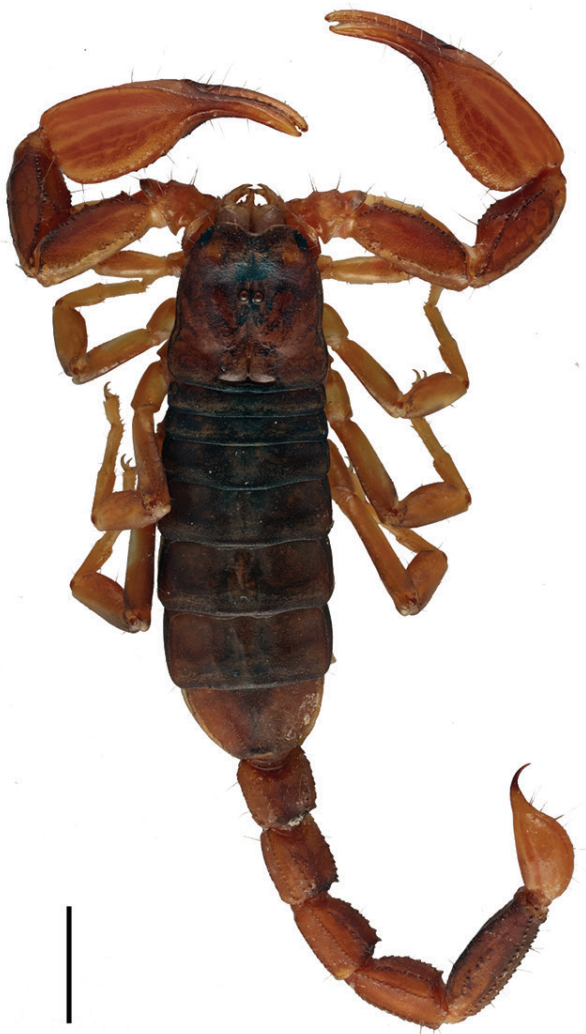

B

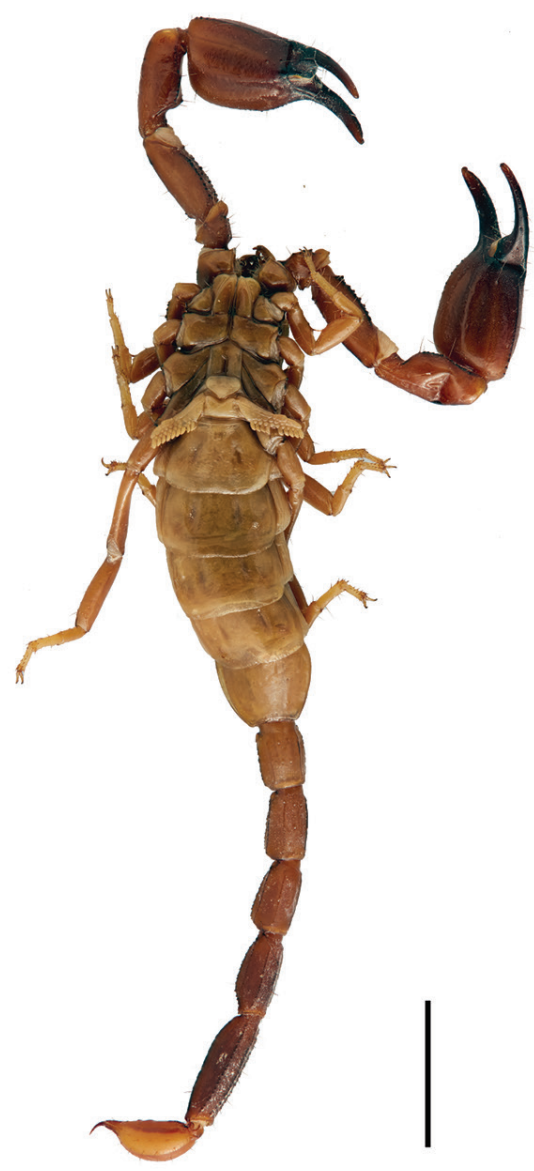

D

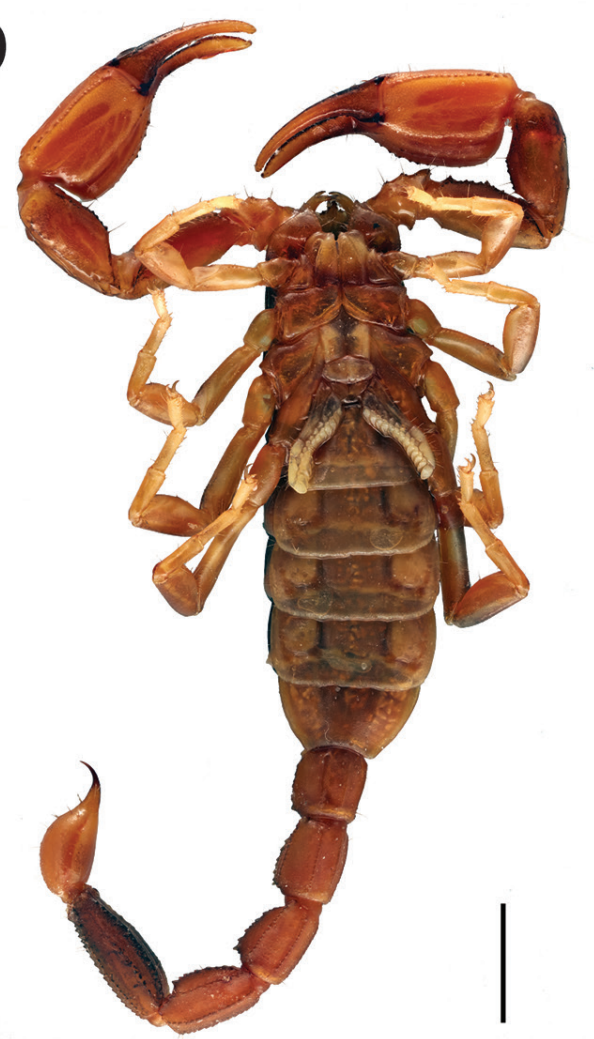

Figure 25. Hemiscorpius maindroni Kraepelin, 1900, female syntype (A-B). Hemiscorpius somalicus Lourenço, 2011, male holotype (C-D): A, $\mathbf{C}$ dorsal aspect of habitus $\mathbf{B}, \mathbf{D}$ ventral aspect of habitus. Scale bars: $10 \mathrm{~mm}(\mathbf{A}-\mathbf{B}), 5 \mathrm{~mm}(\mathbf{C}-\mathbf{D})$. 

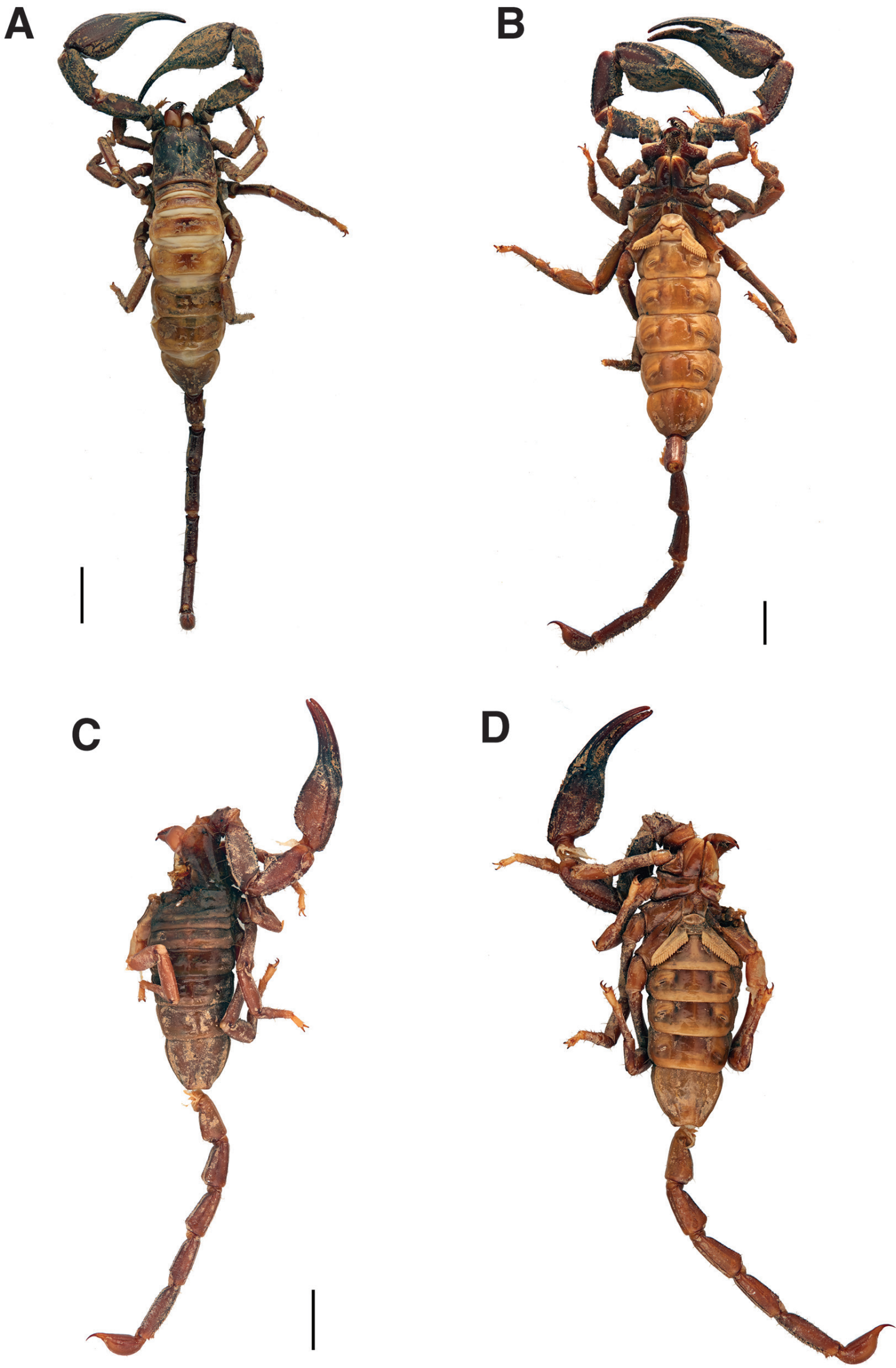

Figure 26. Heteroscorpion opisthacanthoides Kraepelin, 1896, female paralectotype (A-B), juvenile male lectotype (C-D): A, C dorsal aspect of habitus B, D ventral aspect of habitus. Scale bars: $10 \mathrm{~mm}$. 


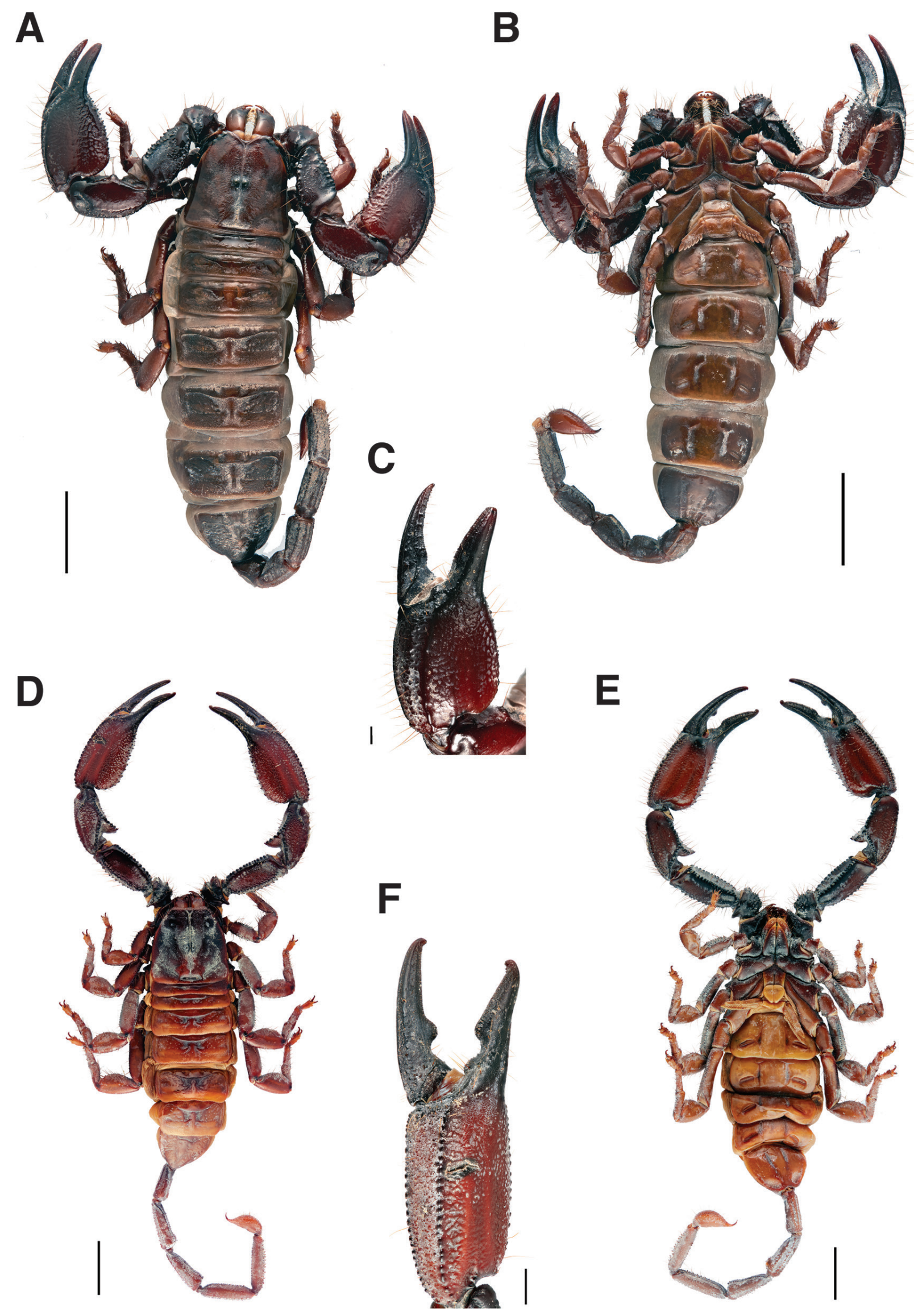

Figure 27. Cheloctonus glaber Kraepelin, 1896, female lectotype (A-C). Ischnurus troglodytes Peters, 1861 [= Hadogenes troglodytes (Peters, 1861)], female syntype (D-F): A, D dorsal aspect of habitus B, E ventral aspect of habitus $\mathbf{C}, \mathbf{F}$ retrolateral aspect of chela illustrating dentate margins of fingers. Scale bars: $10 \mathrm{~mm}(\mathbf{A}-\mathbf{B}), 20 \mathrm{~mm}(\mathbf{D}-\mathbf{E}), 5 \mathrm{~mm}(\mathbf{F}), 1 \mathrm{~mm}(\mathbf{C})$. 


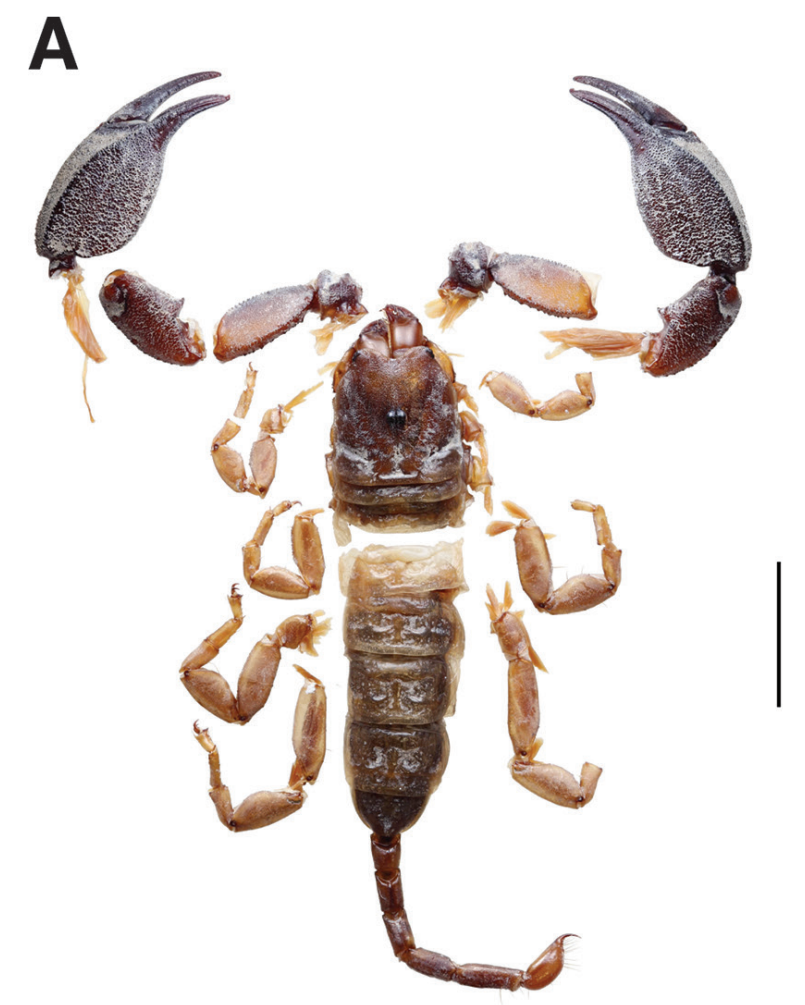

B

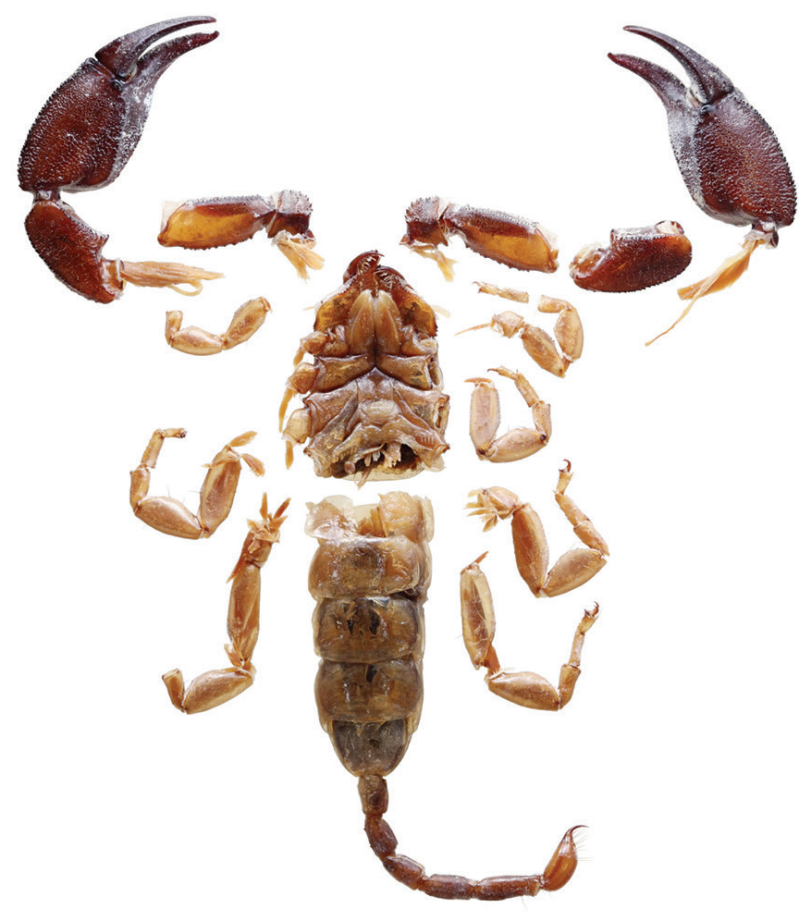

C
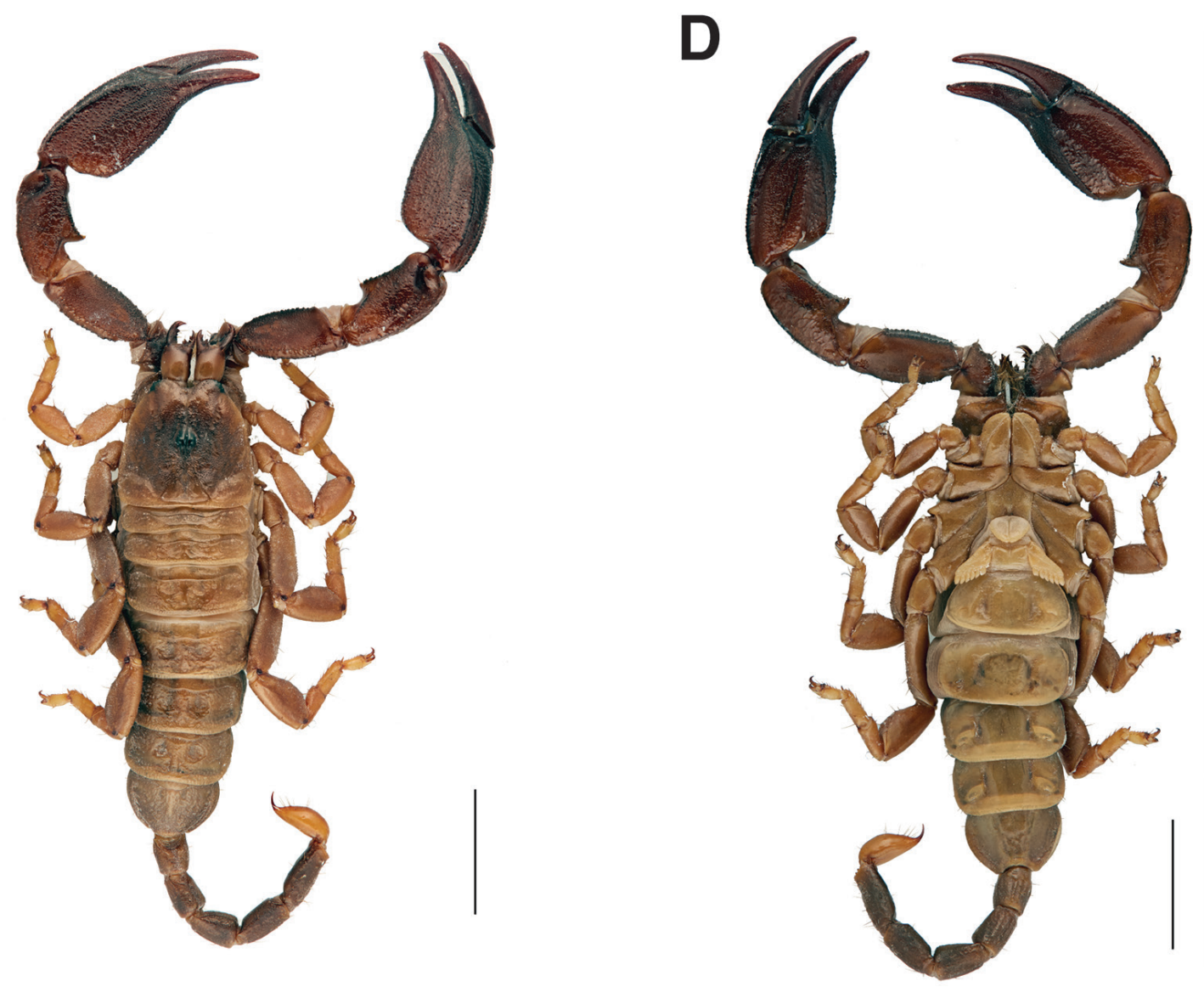

Figure 28. Hormurus boholiensis Kraepelin, 1914, female lectotype (A-B). Ischnurus caudicula L. Koch, 1867 [= Hormurus waigiensis (Gervais, 1843)], subadult female holotype (C-D): A, C dorsal aspect of habitus B, D ventral aspect of habitus. Scale bars: $10 \mathrm{~mm}$. 
Current combination. Hormurus boholiensis Kraepelin, 1914

Lectotype. (Fig. 28A-B) $\circ$, Philippines, [Central Visayas], Bohol [950’00’'N, 124¹0’00’E], 10.1863, ZMK 3938 [Carl Gottfried Semper leg.].

Paralectotype. $\$$, same data as lectotype.

Remarks. Kraepelin (1914d) mentioned that the two type specimens were poorly preserved: "Von dieser Arte liegen mir nur zwei schlecht erhaltene $\rightarrow$ des Hamburger Museum vor.”. H. boholiensis was considered a junior synonym of Liocheles australasiae (Fabricius, 1775) by L. E. Koch (1977: 161). Monod (2011b) revalidated the species as Liocheles boholiensis (Kraepelin, 1914). Monod and Prendini (2015) subsequently removed the genus Hormurus from synonymy with Liocheles and confirmed the species boholiensis as belonging to Hormurus. The larger female of this series was designated as lectotype by Monod (2011b: 726)

Remarks on collector. Although not mentioned on the original labels, the specimens were probably collected by Carl Gottfried Semper (1832-1893), a German malacologist who obtained a Ph.D. degree at the University of Würzburg in 1856 and continued his studies in Kiel. An inheritance from his father allowed him to pay for a seven years trip to the Philippines and Palau (1858-1865) (Schuberg 1880). After returning to Germany, he was appointed lecturer (1866) and professor (1869) at the University of Würzburg. He visited Bohol in 1863 , which corresponds to the collecting date of the two present specimens.

\section{Ischnurus caudicula}

Fig. $28 \mathrm{C}-\mathrm{D}$

Ischnurus caudicula L. Koch, 1867: 237-239

Current senior synonym. Hormurus waigiensis (Gervais, 1843) [synonymized by Kraepelin 1901e: 272]

Holotype. Subadult $q$ (ZMH-A0002225), Australien [Australia], Brisbane [2728'04'S, $\left.153^{\circ} 01^{\prime} 41^{\prime \prime} \mathrm{E}\right]$, coll. 1886, Museum Godeffroy (no. 244).

Remarks on collector. The specimen was almost certainly collected by Amalie Dietrich (1821-1891) who was collecting in Queendland on behalf of the Godeffroy estate from 1863 to 1872 . She was the only woman ever hired for such a position. Dietrich collected extensively in the wider Brisbane region after her arrival but the exact locality data remain unknown.

\section{Hormurus karschii keyensis}

Fig. 29

Hormurus karschii keyensis Kraepelin, 1914d: 331

Current senior synonym. Hormurus karschii Keyserling, 1885 [synonymized by L. E. Koch, 1977: 173]
Lectotype. (Fig. 29A-B) \& (ZMH-A0002226), [Indonesia], [Maluku], Key Inseln [Kai Islands] [5 $45^{\prime} 00^{\prime}$ 'S, 13243’30”E], Hugo Merton leg., ded. 2.11.1908.

Paralectotype. (Fig. 29C-D) subadult $ぇ$ (ZMH-A0002226), same data as lectotype.

Remarks. The adult female is designated as the lectotype and the second specimen as the paralectotype.

Remarks on collector. Hugo Merton (1879-1940) was a German zoologist and Professor of Zoology at the University of Heidelberg. In 1907-1908, he conducted a zoological expedition to the Aroe and Kai Islands with Jean Roux (1876-1939), who was a Swiss zoologist from Basel (Roux 1910; Merton 1911). They travelled via Singapore and Java, finally arriving in Dobo in January 1908. They surveyed the Aru Islands for four months and the Kai Islands for another month (May-June). The present specimens were probably collected in 1908

\section{Ischnurus neocaledonicus}

Fig. 30A-B

Ischnurus neocaledonicus Simon, 1877b: 237-238

Current combination. Hormurus neocaledonicus (Simon, 1877)

Paratype. $q$ (ZMH-A0000915), Neu Caledonien [New Caledonia], 20.08.1900, Bougier leg., MNHN don. (ZMH Eing. Nr. A27/03).

Remarks. Fet (2000a) listed a holotype in the MNHN (Paris) and a paratype in the Hamburg collections. The holotype is considered lost by Monod (2011b: 743). The species Ischnurus neocaledonicus was recently removed from synonymy with Liocheles waigiensis (Monod, 2011b: 724) and is now part of the genus Hormurus, which was recently revalidated by Monod and Prendini (2015).

Remarks on collector. Morat (2010) listed Bougier as a colonisation officer in New Caledonia, where he collected plants for the Paris Museum.

\section{Hormurus papuanus}

Fig. 31

Hormurus papuanus Kraepelin, 1914d: 333 [Hormurus]

Current combination. Hormurus papuanus Kraepelin, 1914

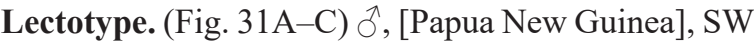
Küste New Pommern [SW coast of New Britain], Liebliche Inseln [Arawe Islands] [6 $6^{\circ} 06^{\prime} 07^{\prime}$ 'S, 148 59'53'E], 11-12.12.1908, 05.01.1909, 26-31.01.1909, (2 T. under Steinen [2 specimens under rocks], 2 T. in moderndem Holz [two specimens in decaying logs]), Georg Duncker leg. (S40), Hamburg Südsee Expedition.

Paralectotype. 1 o, 1 ㅇ (Fig. 31D-F), 5 ㅇ , 4 subadult $\hat{\delta}, 2$ subadult $\odot, 7$ juveniles, same data as lectotype; $1 \hat{\jmath}$, [Papua New Guinea], New Pommern [New Britain], 

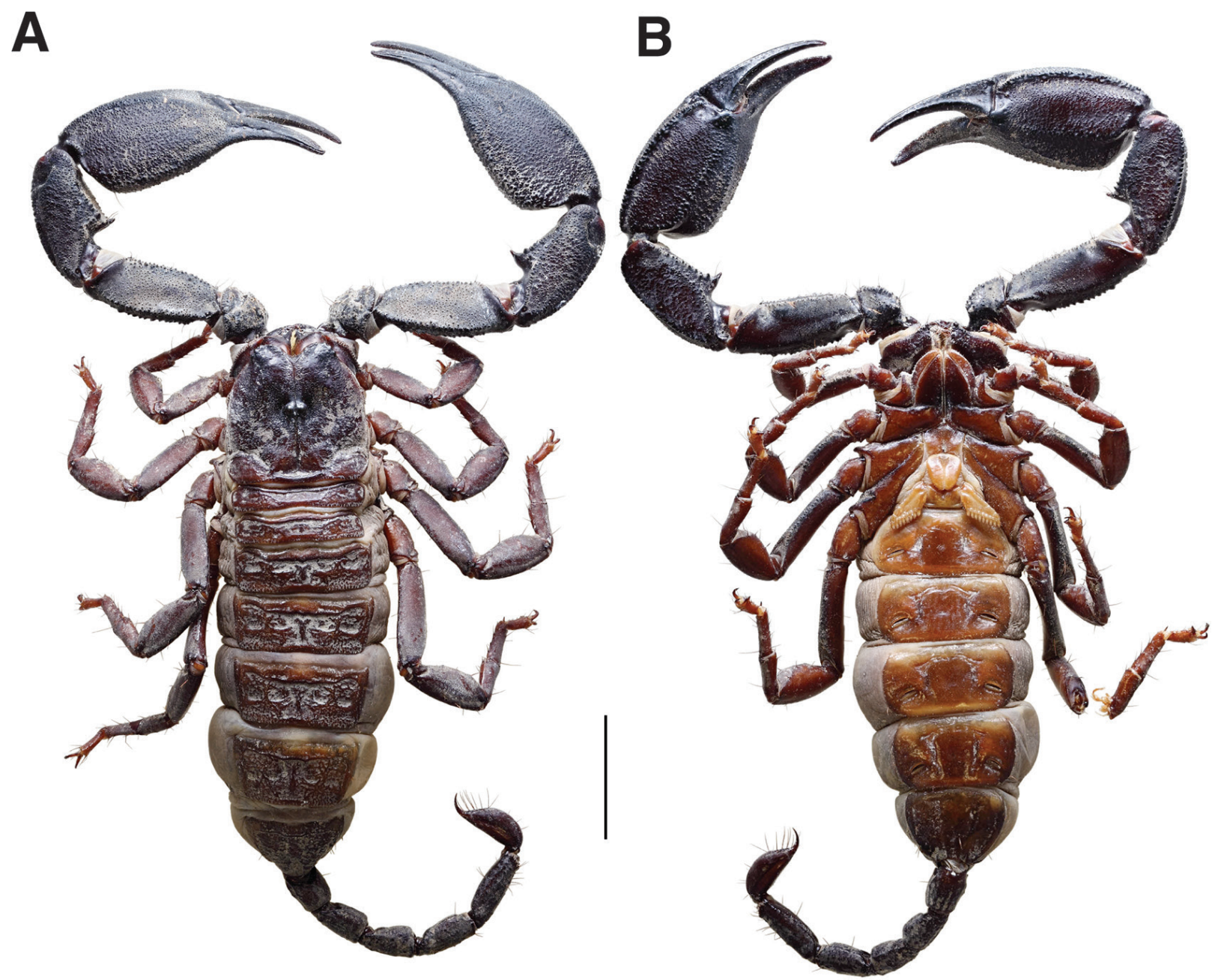

C
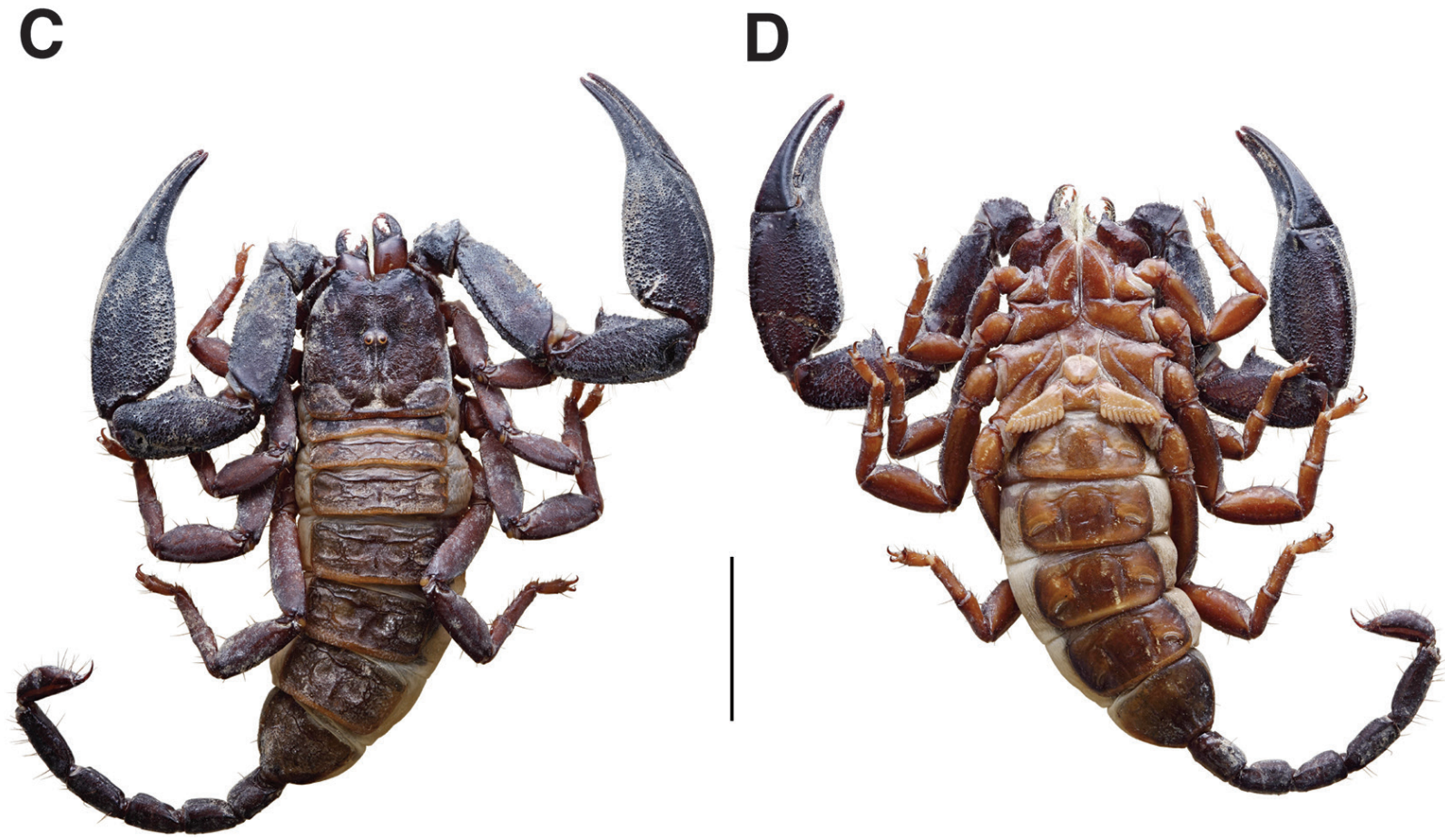

Figure 29. Hormurus karschii keyensis Kraepelin, 1914 [= Hormurus karschii Keyserling, 1885], female lectotype (A-B), subadult male paralectotype (C-D): A, $\mathbf{C}$ dorsal aspect of habitus $\mathbf{B}, \mathbf{D}$ ventral aspect of habitus. Scale bars: $10 \mathrm{~mm}$. 

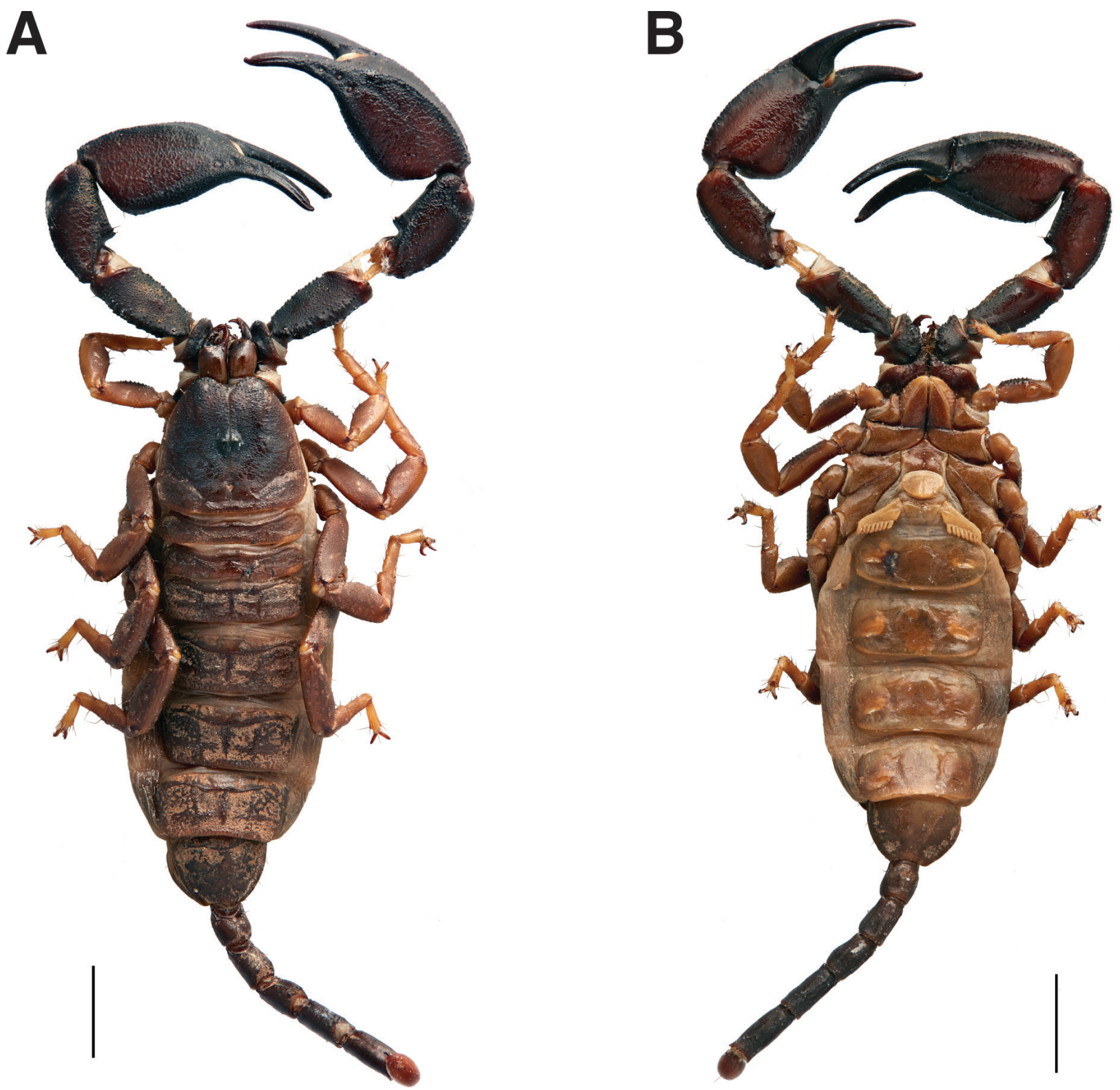

Figure 30. Ischnurus neocaledonicus Simon, 1877 [= Hormurus neocaledonicus (Simon, 1877)], female paratype, habitus A dorsal aspect B ventral aspect. Scale bars: $10 \mathrm{~mm}$.

Möre Hafen [Kandrian] [6¹1'24’S, 149`32‘51’E], Unterlauf des Wasserfall-Fl. [downstream of waterfall], 1314.XII.1908, 20-24.II.1909, Georg Duncker leg. (334), Hamburg Südsee-Expedition.

Remarks. Kraepelin mentioned in the original description 23 specimens from Neu Pommern and Neu Guinea. Among this material, two specimens from Finschafen (Papua New Guinea mainland) belong to a different undescribed species and are thus not considered type specimens of $H$. papuanus. This new species will be described in a forthcoming paper about the genus Hormurus in Papua New Guinea (Monod et al. in prep). An additional specimen from Aru Islands was also mentioned in the original description but it is not considered here as a type. The type locality of species $H$. papuanus is thus restricted to the specimens collect- ed on the SW coast of New Britain (Arawe Islands and Kandrian village).

Giltay (1931: 10) considered H. papuanus as a subspecies of $H$. caudicula, while L. E. Koch (1977: 173) regarded it as a junior synonym of Liocheles karschii (Keyserling, 1885). Monod (2000: 113) revalidated the species and designated lectotype and paralectotypes from this series. A complete redescription will be provided in the publication mentionned above (Monod et al. in prep).

Remarks on collector. (Paul) Georg (Egmont) Duncker (1870-1953) was a German zoologist and ichthyologist. He was employed by the Hamburg Zoological Museum in 1907 and became curator/professor in 1928. He was a member of the Hamburg Südsee-Expedition (1908-1910) in the Bismarck Archipelago and collected on behalf of the ZMH (Thilenius 1914). 

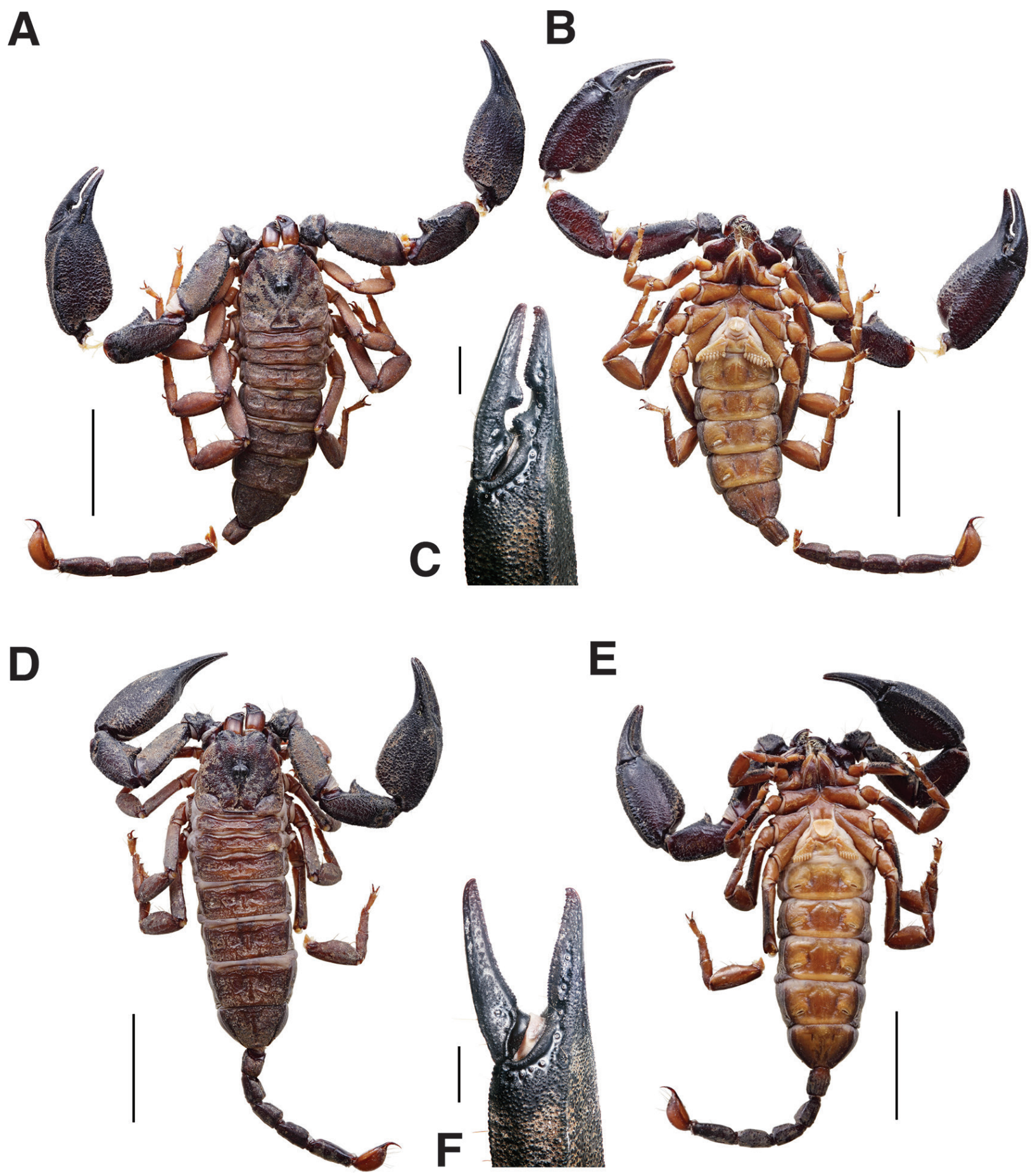

Figure 31. Hormurus papuanus Kraepelin, 1914, male lectotype (A-C), female paralectotype (D-F): A, D dorsal aspect of habitus B, E ventral aspect of habitus $\mathbf{C}, \mathbf{F}$ retrolateral aspect of chela illustrating dentate margins of fingers. Scale bars: $10 \mathrm{~mm}(\mathbf{A}-\mathbf{B}, \mathbf{D}-\mathbf{E}), 2 \mathrm{~mm}(\mathbf{C}, \mathbf{F})$.

\section{Hormurus sarasini}

Fig. 32

\section{Hormurus sarasini Kraepelin, 1914d: 332, 335-336}

Current senior synonym. Hormurus neocaledonicus (Simon, 1877) [synonymized by Monod 2011b: 723, 743]

Paralectotypes. $1 \hat{\delta}$ (Fig. 32A-C, ZMH-A00001059), 1 ㅇ (Fig. 32D-F, ZMH-A00001060), 1 female, 2 subadult $\odot, 2$ juveniles, New Caledonia, Northern Province,
Tchalabel [20²4’00”S, $\left.164^{\circ} 22^{\prime} 00^{\prime \prime} E\right]$, Fritz Sarasin leg., ded. 02.1913 .

Remarks. Most specimens of the type series are deposited in the Naturhistorisches Museum zu Basel, Switzerland (NMB) (Forcart 1961). Lothar Forcart listed 34 specimens in the type catalogue. He designated a lectotype male and 33 paralecotypes (six males and 27 females). The seven ZMH specimens are therefore paralectotypes. Monod (2011b) considered H. sarasini as a junior synonym of $H$. neocaledonicus. 
A
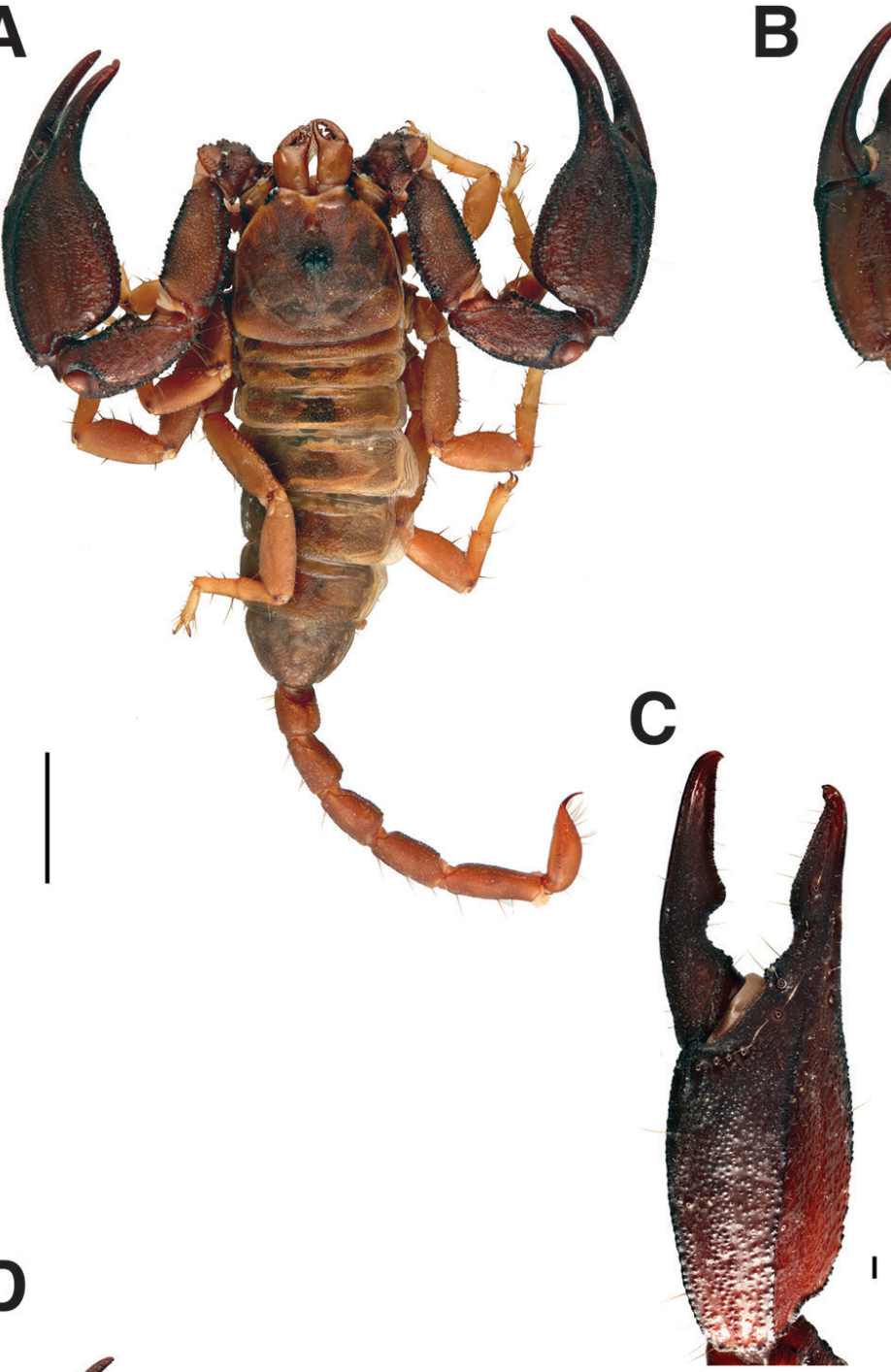

D
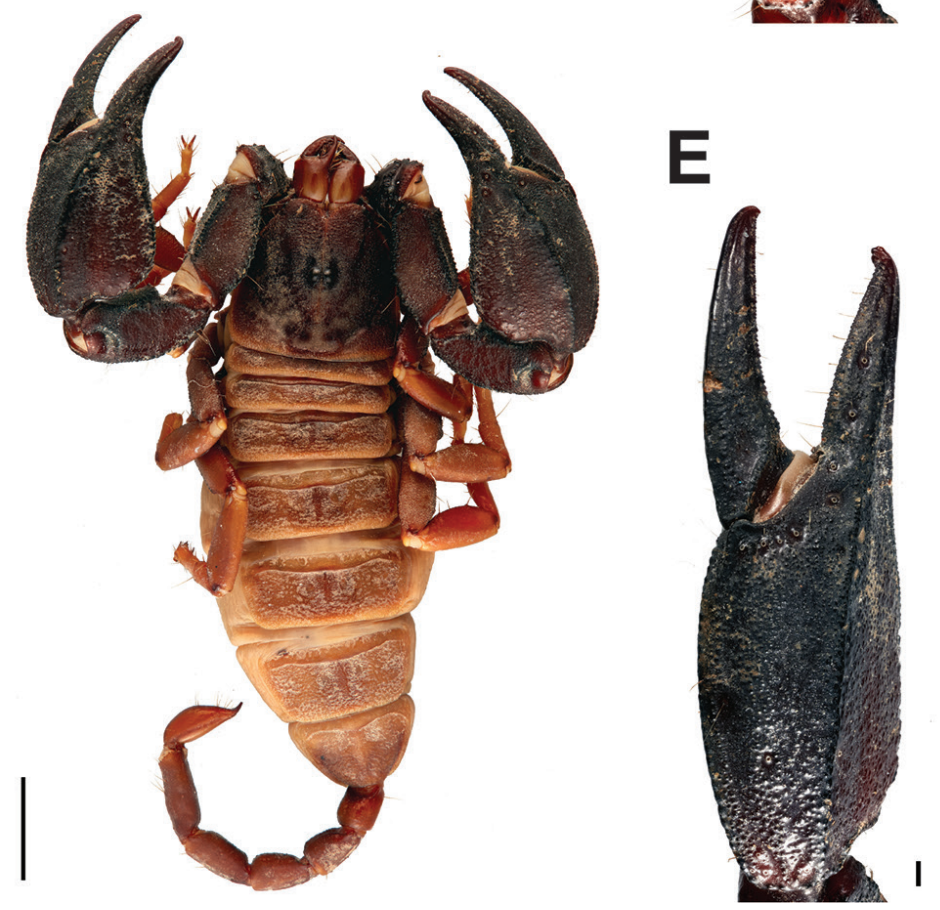

$\mathbf{F}$

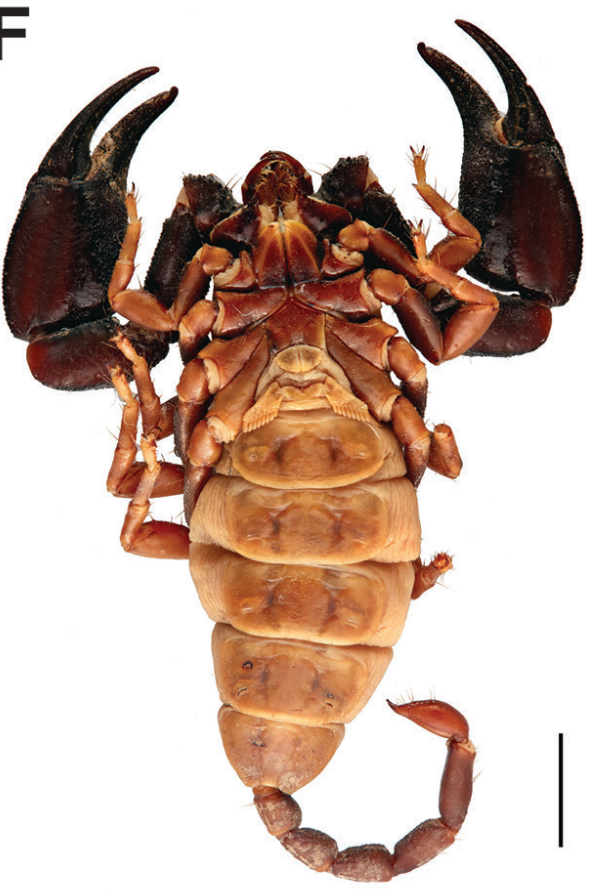

Figure 32. Hormurus sarasini Kraepelin, 1914 [= Hormurus neocaledonicus (Simon, 1877)], male paralectotype (A-C), female paralectotype (D-F): A, D dorsal aspect of habitus B, $\mathbf{E}$ ventral aspect of habitus $\mathbf{C}, \mathbf{F}$ retrolateral aspect of chela illustrating dentate margins of fingers. Scale bars: $10 \mathrm{~mm}(\mathbf{A}-\mathbf{B}, \mathbf{D}-\mathbf{E}), 1 \mathrm{~mm}(\mathbf{C}, \mathbf{F})$. 
Remarks on collector. Karl Friedrich Sarasin (18591942) was a Swiss zoologist and explorer. Together with his cousin Paul Benedikt Sarasin (1856-1929), he led several expeditions in Sulawesi, Sri Lanka, Egypt, Sinai and Tunisia to collect botanical, ethnographical and zoological material. He travelled to New Caledonia and the Loyalty Islands with Jean Roux in 1910-1912 (Sarasin 1931).

\section{Genus Iomachus Pocock, 1893}

\section{Iomachus laeviceps}

Iomachus laeviceps Pocock, 1890: 242-244, pl. XII, fig. 1, 1a

Current combination. Iomachus laeviceps Pocock, 1890

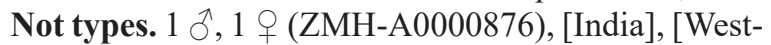
ern Ghats], [Tamil Nadu], Nilgiri Hills [11 ${ }^{\circ} 15^{\prime} 10^{\prime \prime} \mathrm{N}$, 76³0'48'E], 1'000 feet [ca. $305 \mathrm{~m}$ ], 6.06.1897, J. R. Henderson, BMNH don.

Remarks. These specimens, listed by Weidner (1959: 101) as paratypes, are not part of the type series. Iomachus laeviceps was described from a series of specimens collected in Madras by E. Thurston. Pocock mentioned two specimens from Anamalai Hills, Coimbatore that he described later as Iomachus punctulatus (Pocock, 1897b). The two specimens here belong to the species I. laeviceps and are not part of either series, although they were donated to Kraepelin by the British Museum. The rest of the present series (one male, one female, four juveniles) is present in the BMNH collections.

\section{Iomachus politus occidentalis}

Fig. 33A-B

Iomachus politus occidentalis Lourenço, 2003: 138-141, 146, fig. 1-7

Current combination. Iomachus politus occidentalis Lourenço, 2003

Holotype. + (ZMH-A0001083), Western Africa, Congo (Ex-Zaire) [Democratic Republic of the Congo], [Tshuapa], Befori [0¹0'28'N, 22²2'52'E], 12.1963, C. Alluaud leg.

\section{Genus Liocheles Sundevall, 1833}

\section{Hormurus australasiae brevidigitatus Fig. 33C-D}

Hormurus australasiae brevidigitatus Werner, 1936: 190

Current senior synonym. Liocheles australasiae (Sundevall, 1775) [synonymized by Monod 2011b: 726]

Holotype. \& (ZMH-A0000934), [Indonesia], Java, Buitenzorg [Bogor] [6³5'40”S, 106 47'21'”E], Botanischer Garten [Botanical Garden], 21.01.1925, Hans Winkler leg.

Remarks on collector. Hans Winkler (1877-1945) was a German botanist who first coined the term «ge- nome» from the combination of the words «gene» and «chromosome» (Winkler 1920). He travelled to Indonesia (Dutch East Indies at the time) in 1903/04 and worked in Bogor for several months. He subsequently became Professor at the University in Hamburg and Director of the Botanical Garden. In 1924-1925 he visited Indonesia a second time with the aim to collect material on behalf of his institute (Dammerman 1945). He arrived in Bogor in September 1924, departed for Borneo in late October 1924 (Winkler 1927a, b), and returned to Bogor in late Febuary 1925. He collected at Situ Gunong (S. slope of Gunung Gedeh) in Bogor.

\section{Genus Opisthacanthus Peters, 1861 \\ Subgenus Monodopisthacanthus Lourenço, 2001}

\section{Opisthacanthus (Monodopisthacanthus) andohahela}

Opisthacanthus (Monodopisthacanthus) andohahela Lourenço, 2014a: 181-185, figs 5-19 (with illustration of habitus)

Current combination. Opisthacanthus (Monodopisthacanthus) andohahela Lourenço, 2014

Paratypes. 1 đ, 1 ๆ, 3 juveniles (ZMH-A0002222), Madagascar, Toliara Province, [Atsimo-Andrefana Region], Parc National d'Andohahela [Andohahela National Park] [2436'03'S, 4641'58'E], S Vohibaka, Parcel 1, forêt humide [mesic forest], $560 \mathrm{~m}$ alt., X.1971, C. J. M. Betsch leg., RCP 225 (ZMH Eing. Nr. A2/15).

Remarks. The holotype and three paratypes are deposited in the MNHN collections.

\section{Opisthacanthus madagascariensis}

Fig. 34

Opisthacanthus madagascariensis Kraepelin, 1894: 120, 125-126, pl. II, fig. 44, 51

Current combination. Opisthacanthus (Monodopisthacanthus) madagascariensis Kraepelin, 1894

Lectotype. (Fig. 34A-C, ZMH-A0000918), Madagascar, [Mahajanga Province], [Boeny Region], Ma-

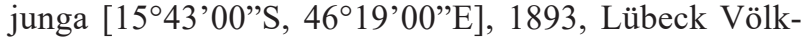
erkundemuseum.

Paralectotype. ㅇ (ZMH-A0001871), same data as lectotype.

Remarks. Kraepelin (1894) mentioned an additional specimen from the Berlin Museum in the type material. According to the ZMB online catalogue, a paratype from Majunga is present in their collection (ZMB/ Arach-3823). This specimen is thus part of the type series and a syntype. One specimen is designated as lectotype and the other as paralectotype.

Remarks on collector. These specimens were probably collected by P. Frey. Brancsik (1893) mentioned that Frey reached Nosy Bé from Majunga. 


\section{A}

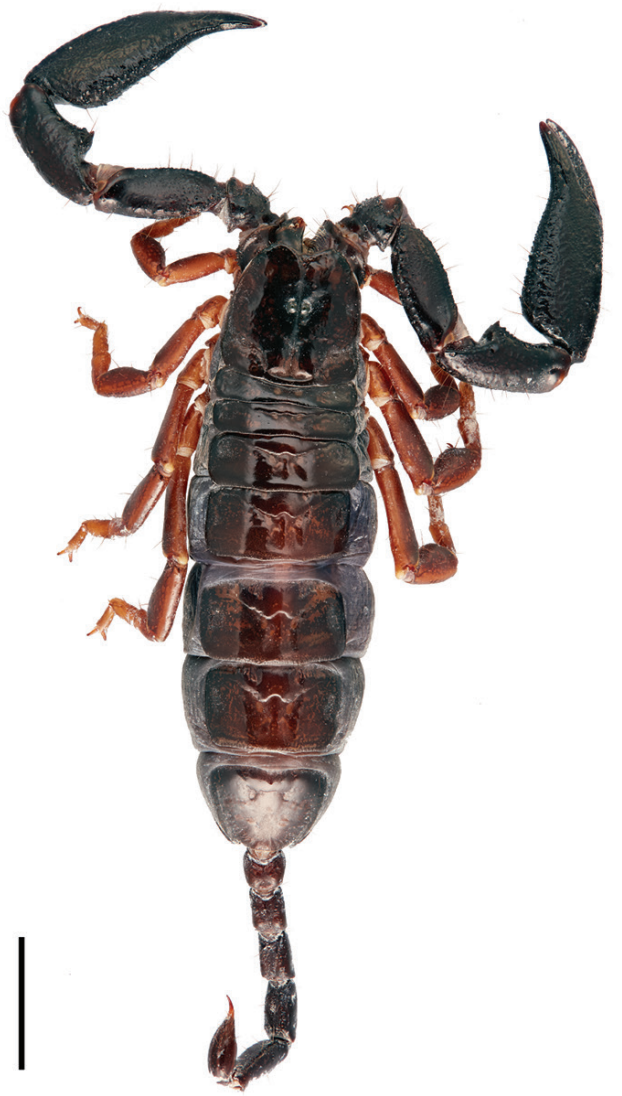

C

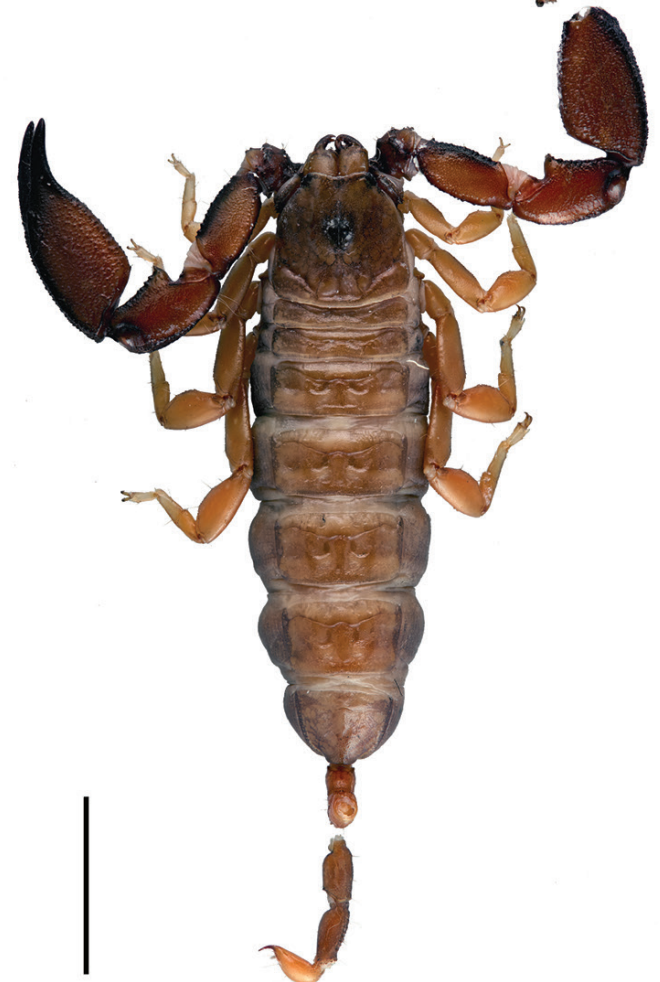

B

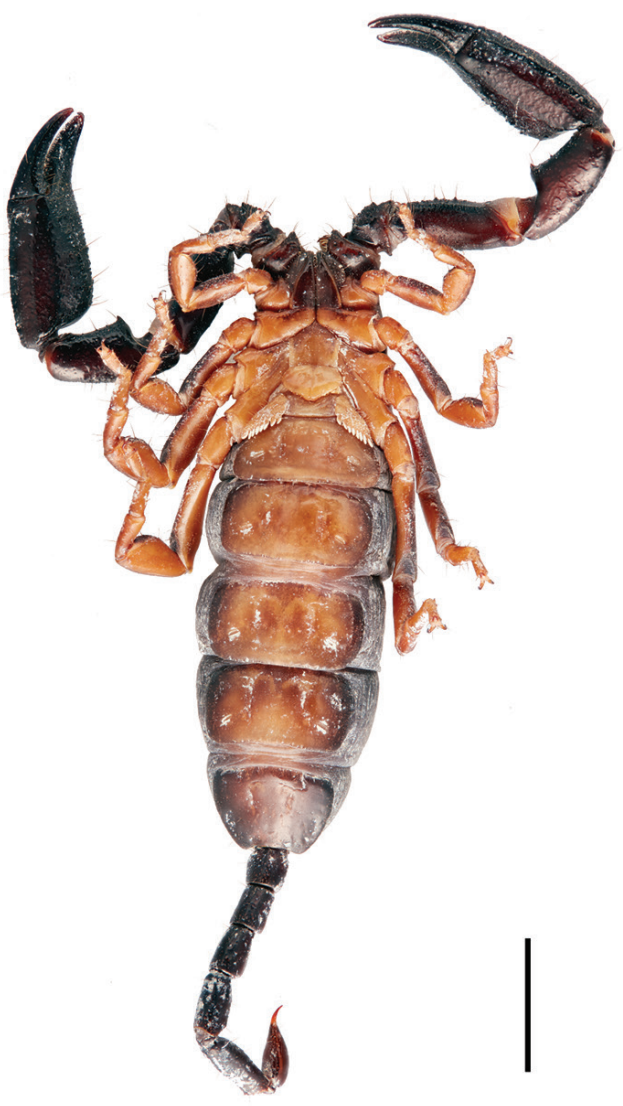

D

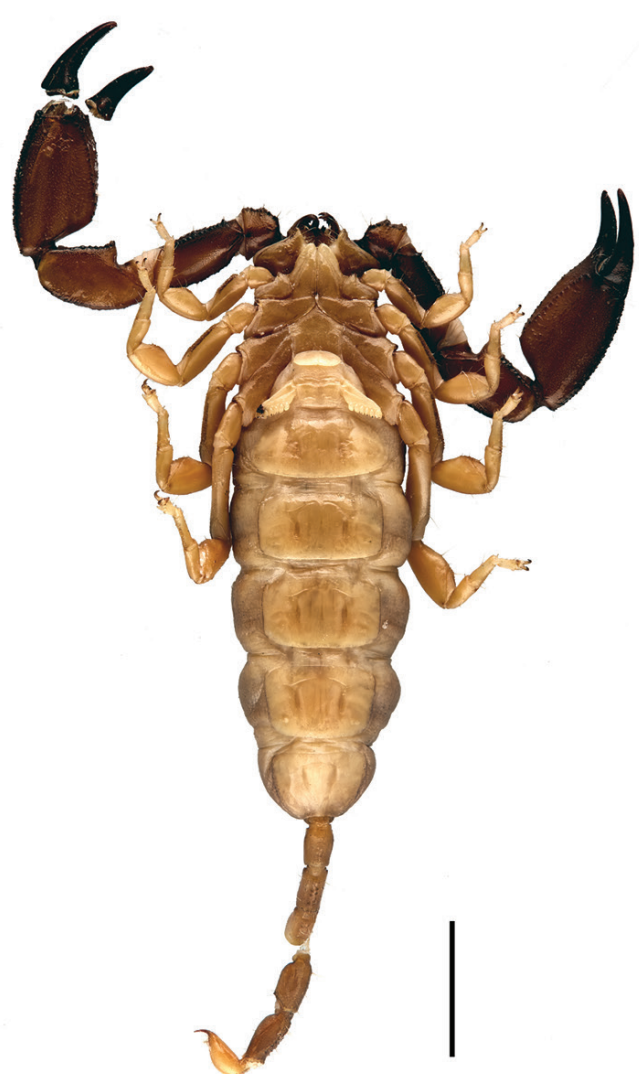

Figure 33. Iomachus politus occidentalis Lourenço, 2003, female holotype (A-B). Hormurus australasiae brevidigitatus Werner, 1936 [= Liocheles australasiae (Sundevall, 1775)], female holotype (C-D): A, C dorsal aspect of habitus B, D ventral aspect of habitus. Scale bars: $10 \mathrm{~mm}$. 


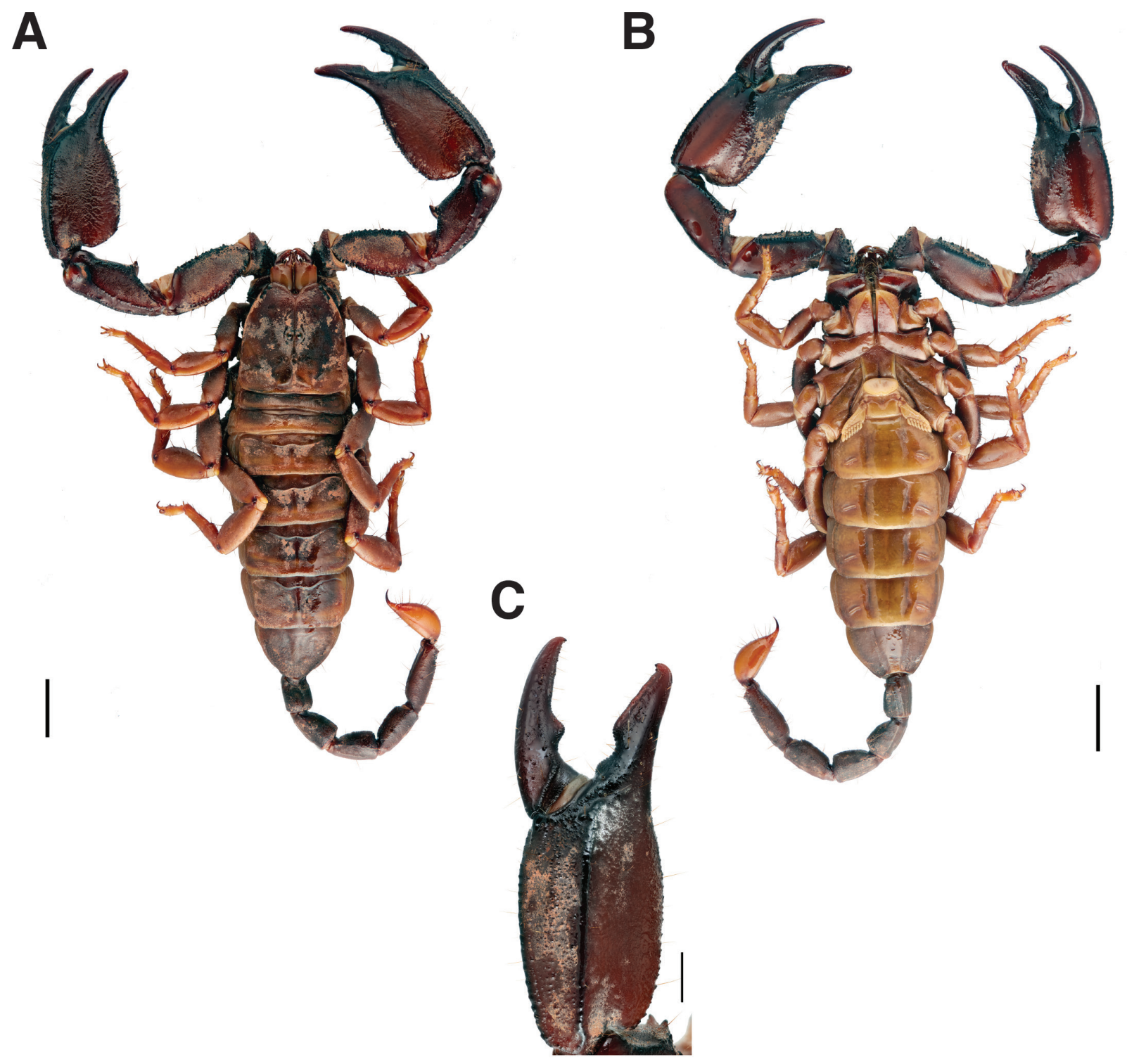

Figure 34. Opisthacanthus madagascariensis Kraepelin, 1894, female syntype A dorsal aspect of habitus B ventral aspect of habitus $\mathbf{C}$ retrolateral aspect of chela illustrating dentate margins of fingers. Scale bars: $10 \mathrm{~mm}(\mathbf{A}-\mathbf{B}), 5 \mathrm{~mm}(\mathbf{C})$.

\section{Subgenus Nepabellus Francke, 1974}

\section{Opisthacanthus aequispinus}

Fig. $35 \mathrm{~A}-\mathrm{C}$

Opisthacanthus aequispinus Kraepelin, 1911: 75, 80-81

Current senior synonym. Opisthacanthus (Nepabellus) diremptus (Karsch, 1879) [synonymized by Lourenço 1987: 909]

Syntypes. $1 \lambda$ (Fig. $35 \mathrm{~A}-\mathrm{C}$ ), 2 juveniles (ZMH-A0001065), [South Africa], Südliche Kaplande [S Western Cape], Zwarteberg Pass [Swartberg Pass] [3320'59''S, 22॰03'00'E], 1.04.1909, S. Afer leg., Museum Amsterdam don.

\section{Ischnurus asper}

Fig. 35D-F

Ischnurus asper Peters, 1861b: 513-514

Current combination. Opisthacanthus (Nepabellus) asper (Peters, 1861).

Syntype. + (Fig. 35D-F, ZMH-A0000917), Mozam-

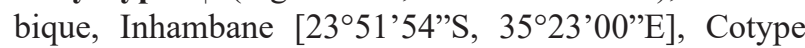
des Originals [co-type of the original], 05.1911, W. Peters leg (ZMB).

Remarks. Three syntypes from Inhambane are present in the ZMB collections (ZMB/Arach-47, ZMB/Arach-7241). Peters did not provide the number of specimens in his original description. Although referred to as a co-type on the 

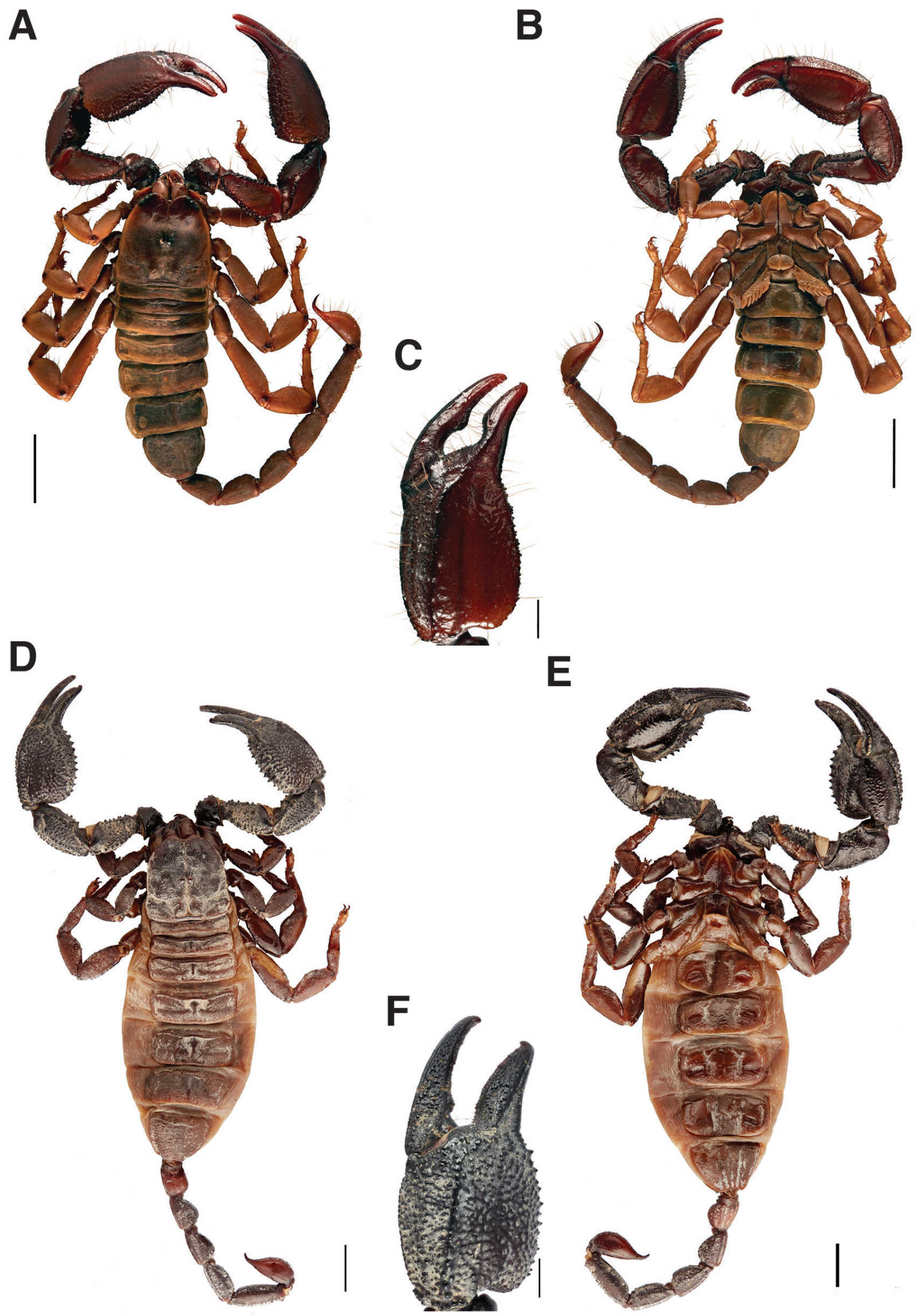

Figure 35. Opisthacanthus aequispinnus Kraepelin, 1911 [= Opisthacanthus diremptus (Karsch, 1879)], male syntype (A-C). Ischnurus asper Peters, 1861 [= Opisthacanthus asper (Peters, 1861)], female syntype (D-F): A, D dorsal aspect of habitus B, E ventral aspect of habitus $\mathbf{C}, \mathbf{F}$ retrolateral aspect of chela illustrating dentate margins of fingers. Scale bars: $10 \mathrm{~mm}(\mathbf{A}-\mathbf{B}, \mathbf{D}-\mathbf{E}), 5 \mathrm{~mm}(\mathbf{C}, \mathbf{F})$. 
label, the specimen in the ZMH likely belongs to the type series (matching locality and referred to as a gift from the original author) and is thus considered a syntype.

\section{Opisthacanthus fischeri}

Fig. 36

Opisthacanthus fischeri Kraepelin, 1911: 74, 79

Current senior synonym. Opisthacanthus (Nepabellus) rugiceps Pocock, 1897 [synonymized by Lourenço 1987: 915]

Lectotype. (Fig. 36A-C) त (ZMH-A0001092), Deutsch-Ostafrika [German East Africa = Kenya-Tanzania border], Nguruman [1 ${ }^{\circ} 54^{\prime} 09$ 'S, 3600'18'E], Gebiet des Kilimandjaro [Kilimanjaro area], Maragoya-Tembo [3²6’30'S, 37¹5’37’'E], 19.01.1884, Gustav A. Fischer leg. (ZMH, typ. Kat. Scorpio. Nr. 79 (9211-9212)).

Paralectotype. $1 \delta$ (ZMH-A0001066), 1 q (Fig. 36DF, ZMH-A0001091) same data as lectotype.

Remarks. A male is designated as lectotype and the two remaining specimens as paralectotypes.

Remarks on collector. Gustav Adolf Fischer (18481886) was a German explorer who practiced as a military physician. In October 1882, he travelled to western Africa with the support of the Geographical Society of Hamburg (Fischer 1885a, b). He reached the Maasai Country from the mouth of the Pangani River, traveling all the way up to Lake Naivasha and the southern foothills of Kilimandjaro. He returned to Germany in November 1883.

\section{Opisthacanthus minor}

Fig. 37

Opisthacanthus minor Kraepelin, 1911: 75, 79-80

Current senior synonym. Opisthacanthus (Nepabellus) validus Thorell, 1876 [synonymized by Lourenço 1987: 905]

Syntypes. 1 subadult $\hat{\delta}$ (Fig. 37A-B), 1 subadult $q$ (Fig. 37C-D), 3 juveniles (ZMH-A0001093), [South Africa], Kapland [Western Cape], Frenchhoek in der Nähe von Kapstadt [Franschhoek Valley near Cape Town] [3354'38”S, 1907'11’'E], 01.04.1909, S. Afer leg., Museum Amsterdam don.

Remarks. Kraepelin (1911) mentioned the presence of specimens von Mphome, Transvaal (South Africa) in the Berlin Museum. Fet (2000a) listed 7 syntypes in the $\mathrm{ZMB}$ collections. The specimens have registration numbers ZMB/Arach-7319 and ZMB/Arach-7321.

\section{Opisthacanthus obscurus}

Fig. 38

Opisthacanthus obscurus Kraepelin, 1911: 76, 81-82
Current senior synonym. Opisthacanthus (Nepabellus) capensis Thorell, 1876 [synonymized by Hewitt 1918: 169]

Lectotype. (Fig. 38A-C) ते (ZMH-A0001095), [South Africa], Süd Kapland [Western Cape], Knysna [3402'10"S, 2302'49”E], 01.04.1909, Museum Amsterdam.

Paralectotypes. 19 (Fig. 38D-E, ZMH-A0001094), 3 (ZMH-A0002221), same data as lectotype.

Remarks. A male from the syntype series is designated here as the lectotype and the four remaining specimens are designated as paralectotypes.

\section{Opisthacanthus transvaalicus ochripes}

Fig. 39

Opisthacanthus transvaalicus ochripes Kraepelin, 1911: 82

Current senior synonym. Opisthacanthus (Nepabellus) validus Thorell, 1876 [synonymized by Lourenço 1987: 905]

Lectotype. (Fig. 39A-C) § (ZMH-A0001097), [South Africa], Transvaal, 04.04.1909, Museum Amsterdam.

Paralectotypes. 1 (Fig. 39D-E, ZMH-A0001096), $1 \curvearrowright, 2$ subadult $q, 1$ juvenile, same data as lectotype.

Remarks. A male from the syntype series is designated here as lectotype and the remaining specimens as paralectotypes. Opisthacanthus transvaalicus ochripes and O. transvaalicus Kraepelin, 1911 (see below) are currently considered junior synonyms of $O$. validus. However, the morphology of chelal fingers in males (the length of fingers compare to the manus and the lobe and notch of the cutting edges) are markedly different in these two taxa (see Fig. 39C and 41C), indicating that they should be considered as distinct species. Therefore at least one of these taxa should be separated from $O$. validus, and possibly both. However, examination of the type specimens of $O$. validus is necessary to unambiguously clarify the taxonomic status of $O$. transvaalicus and $O$. transvaalicus ochripes. For the time being, both taxa are left in the synonymy of $O$. validus.

\section{Opisthacanthus africanus pallidus}

Fig. 40

Opisthacanthus africanus pallidus Lourenço, 2003: 141146, fig. 14-17

Current combination. Opisthacanthus (Nepabellus) africanus pallidus Lourenço, 2003

Holotype. (Fig. 40D-F) $\bigcirc$ (ZMH-A0001085), Western Africa, Angola, Luanda, Zovo, Mabete, Caungula $\left(8.07^{\circ} \mathrm{S}, 18.08^{\circ} \mathrm{E}\right.$, alt. $\left.850 \mathrm{~m}\right), 17-19.07 .1962$, trou d'arbre debout [hole in standing tree], A. de Barros Machado leg. (ZMH Eing. Nr. A28/03).

Paratypes. 1 त $\quad$ (Fig. $40 \mathrm{~A}-\mathrm{C}$ ), 4 juveniles (ZMH-A0001084), same as holotype (ZMH Eing. Nr. A29/03). 
A

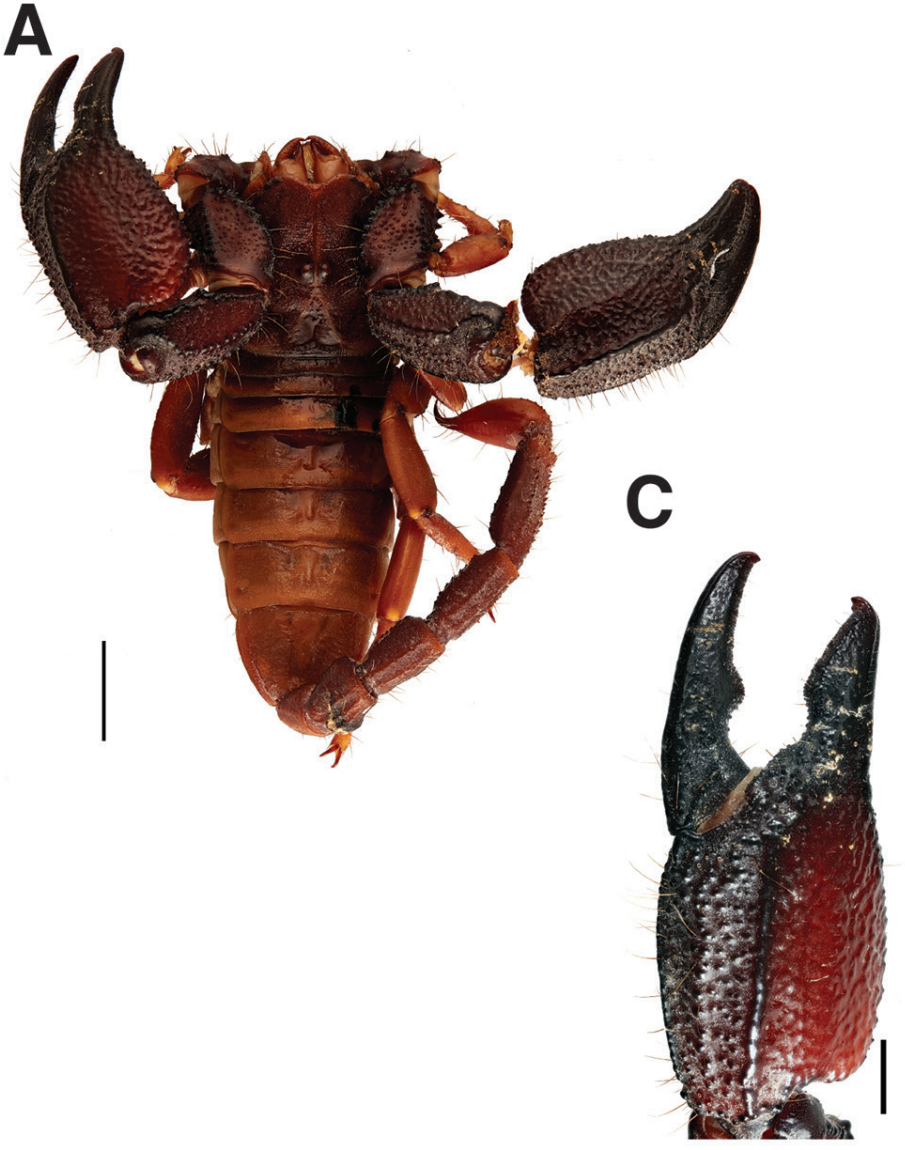

B

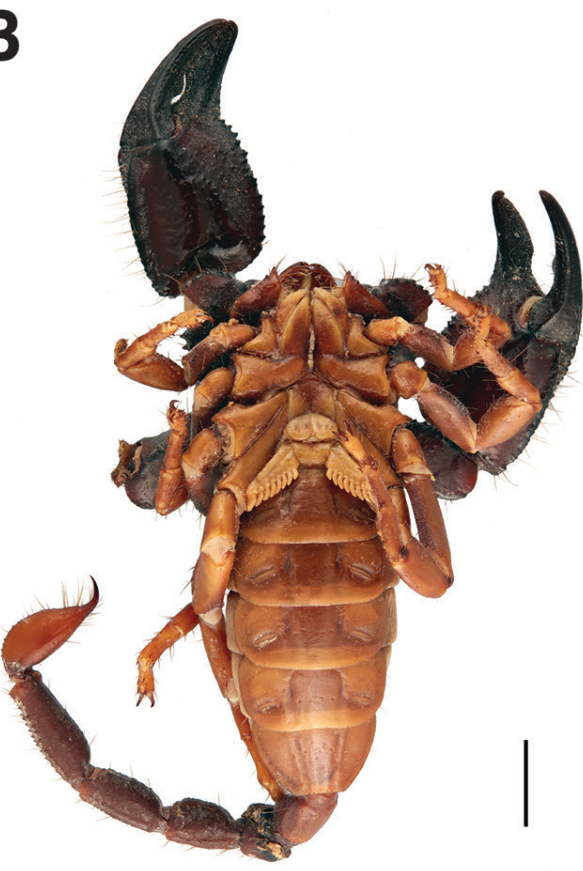

$\mathbf{F}$

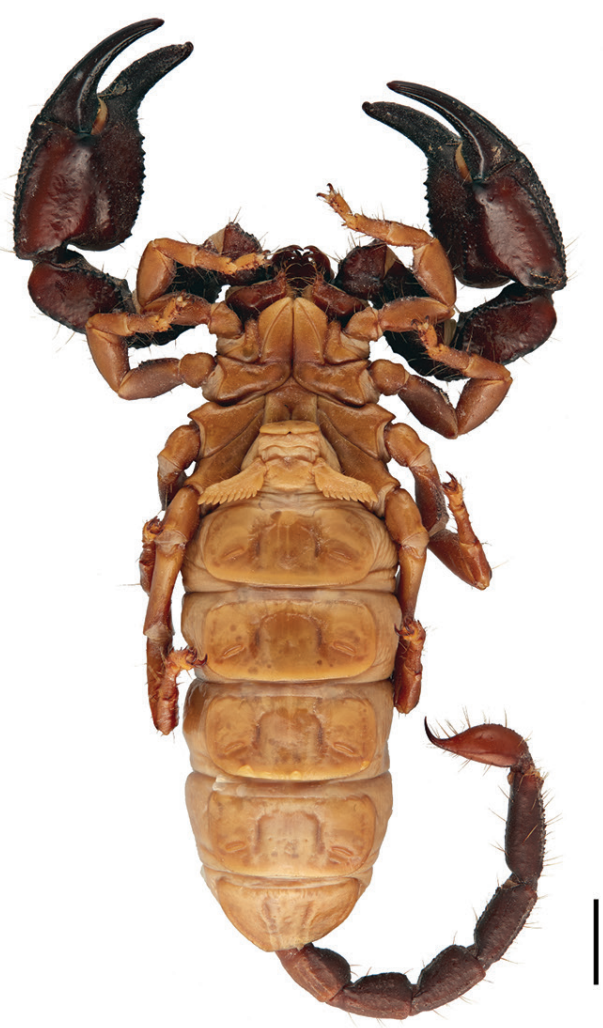

D

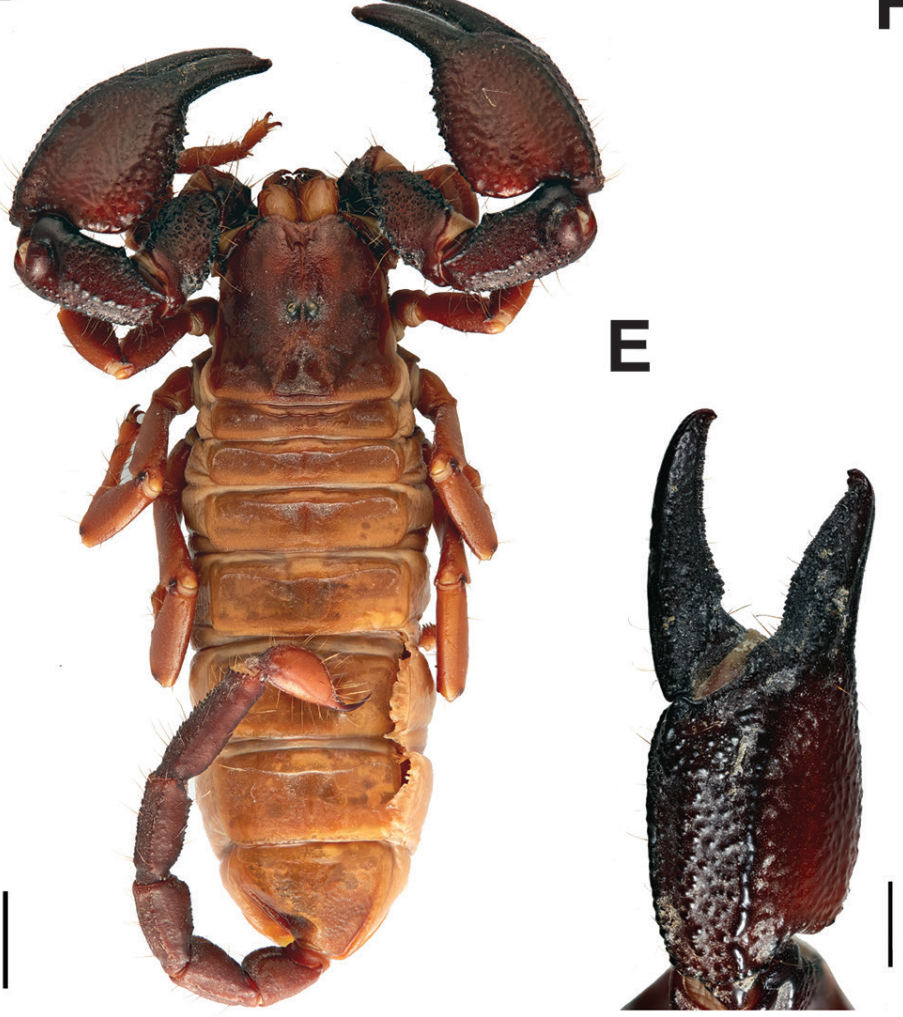

Figure 36. Opisthacanthus fischeri Kraepelin, 1911 [= Opisthacanthus rugiceps Pocock, 1897], male lectotype (A-C), female paralectotype (D-F): A, D dorsal aspect of habitus $\mathbf{B}, \mathbf{E}$ ventral aspect of habitus $\mathbf{C}, \mathbf{F}$ retrolateral aspect of chela illustrating dentate margins of fingers. Scale bars: $10 \mathrm{~mm}(\mathbf{A}-\mathbf{B}, \mathbf{D}-\mathbf{E}), 5 \mathrm{~mm}(\mathbf{C}, \mathbf{F})$. 

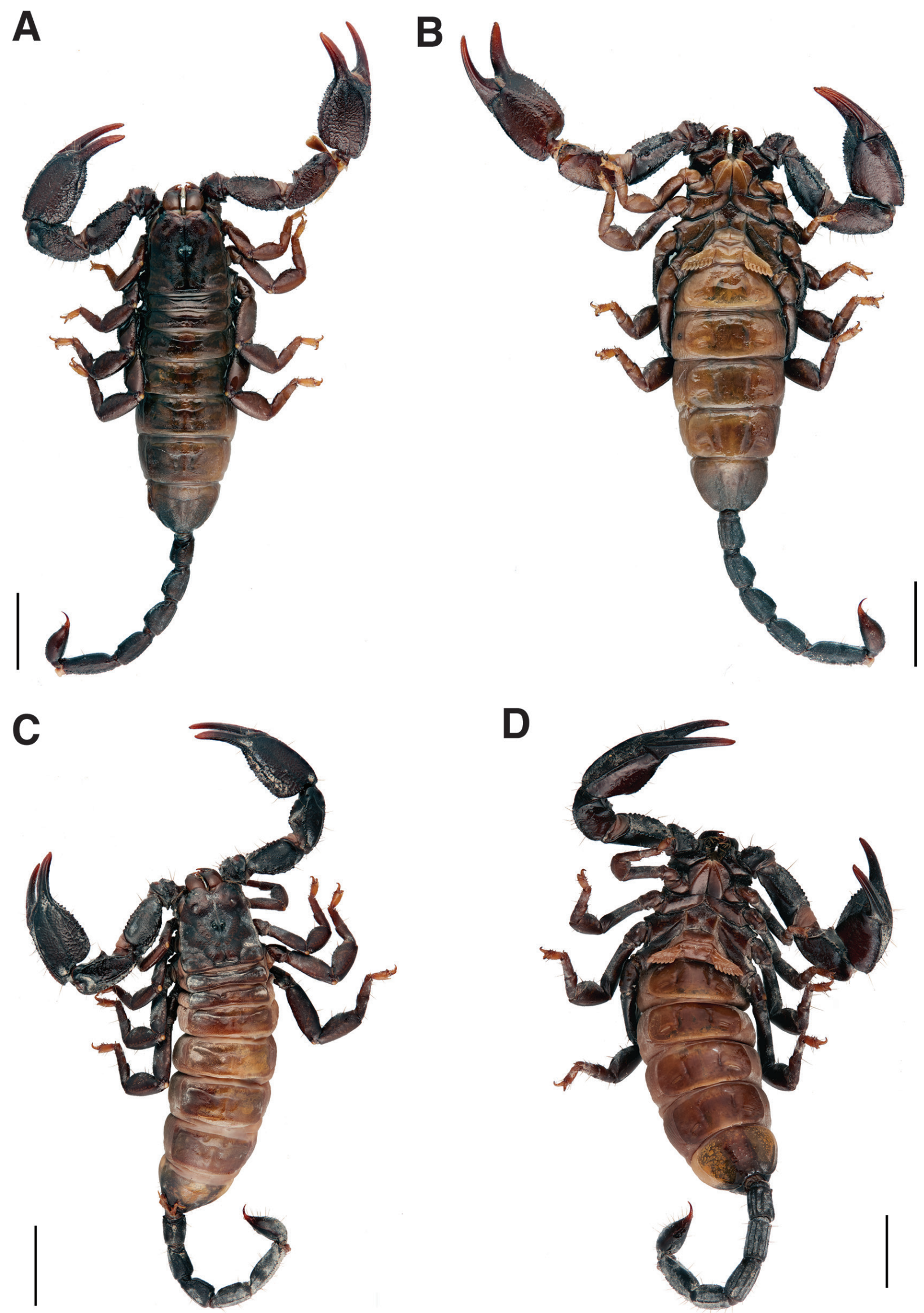

Figure 37. Opisthacanthus minor Kraepelin, 1911 [= Opisthacanthus validus Thorell, 1876], subadult male syntype (A-B), subadult female syntype (C-D): A, C dorsal aspect of habitus $\mathbf{B}, \mathbf{D}$ ventral aspect of habitus. Scale bars: $10 \mathrm{~mm}$. 
A

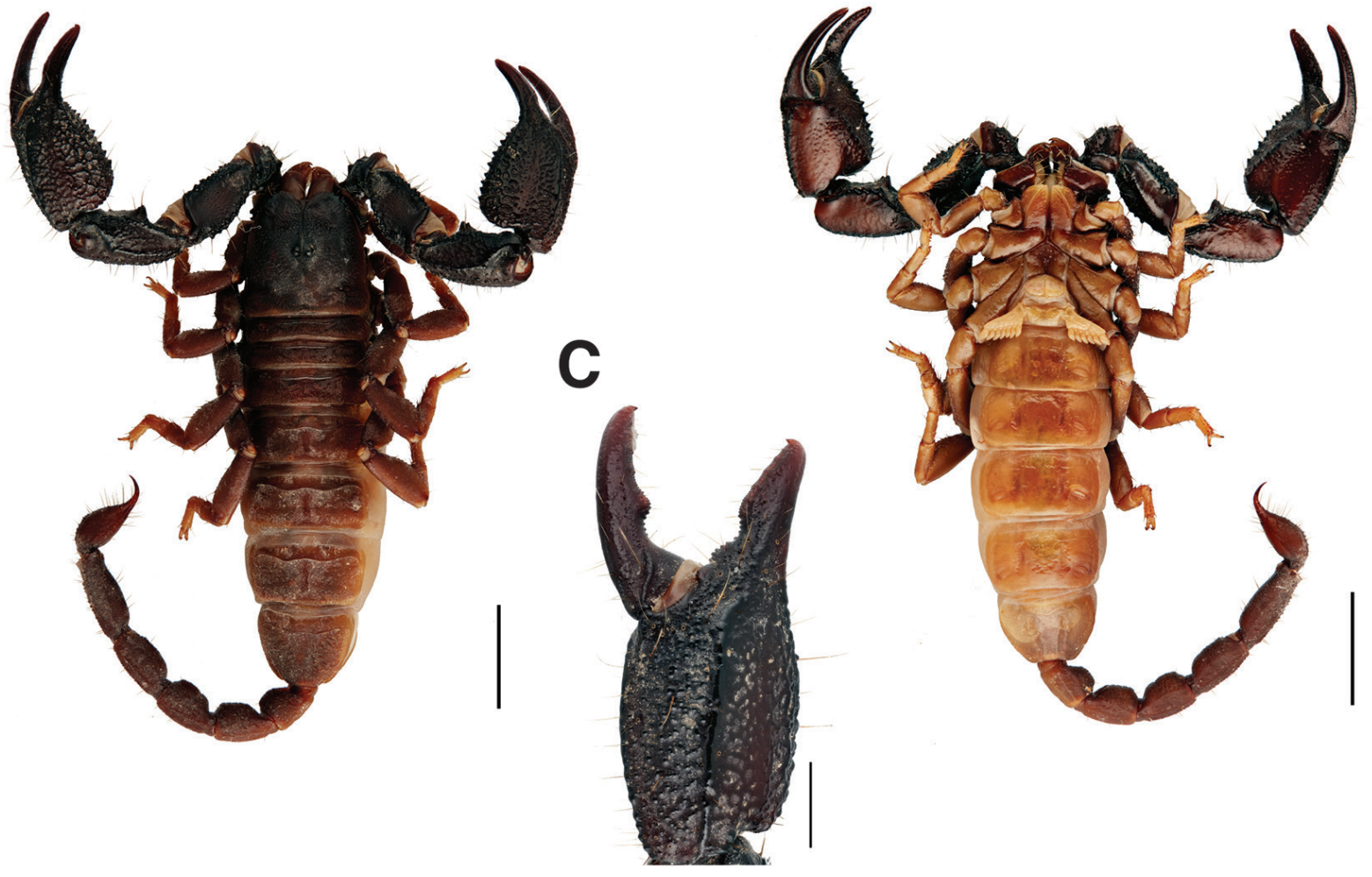

D

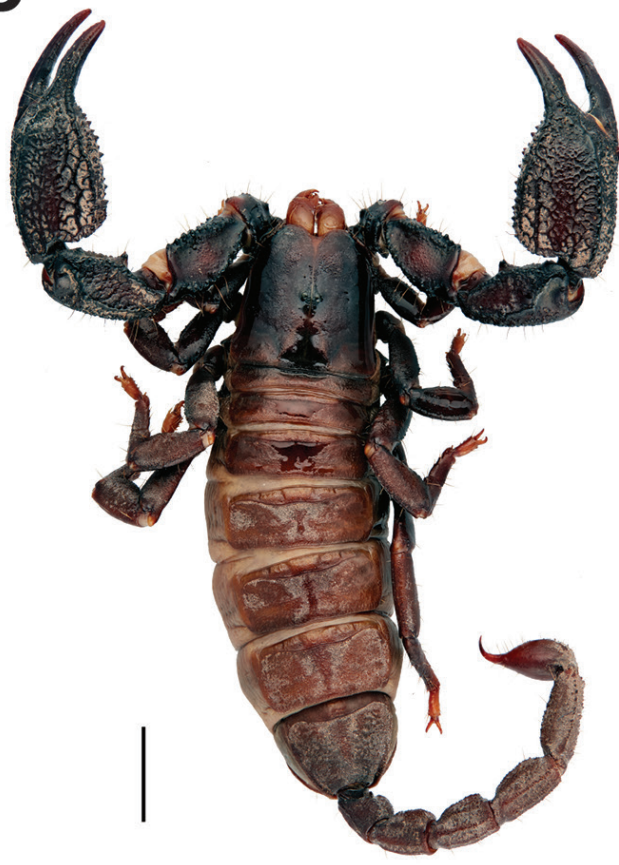

B
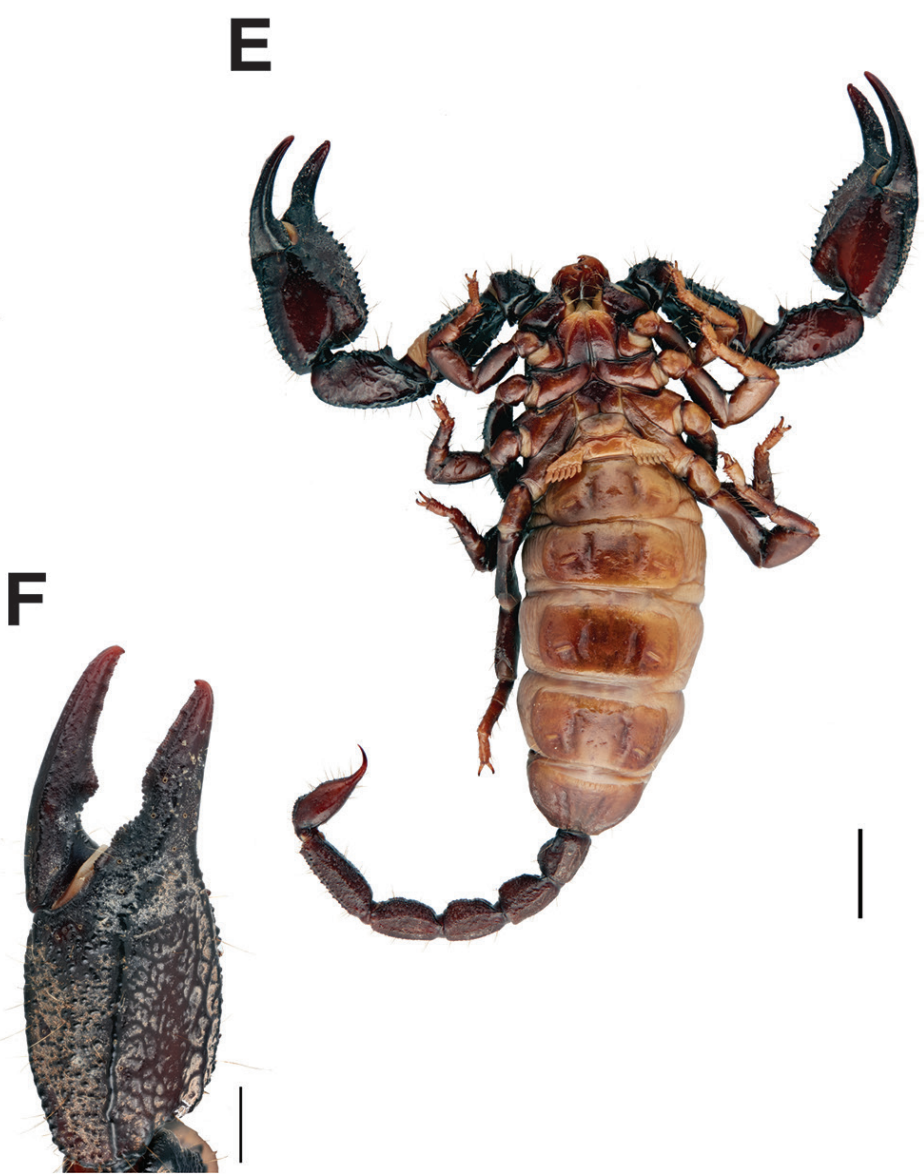

Figure 38. Opisthacanthus obscurus Kraepelin, 1911 [= Opisthacanthus capensis Thorell, 1876], male lectotype (A-C), female paralectotype (D-F): A, D dorsal aspect of habitus B, $\mathbf{E}$ ventral aspect of habitus $\mathbf{C}, \mathbf{F}$ retrolateral aspect of chela illustrating dentate margins of fingers. Scale bars: $10 \mathrm{~mm}(\mathbf{A}-\mathbf{B}, \mathbf{D}-\mathbf{E}), 5 \mathrm{~mm}(\mathbf{C}, \mathbf{F})$. 
A
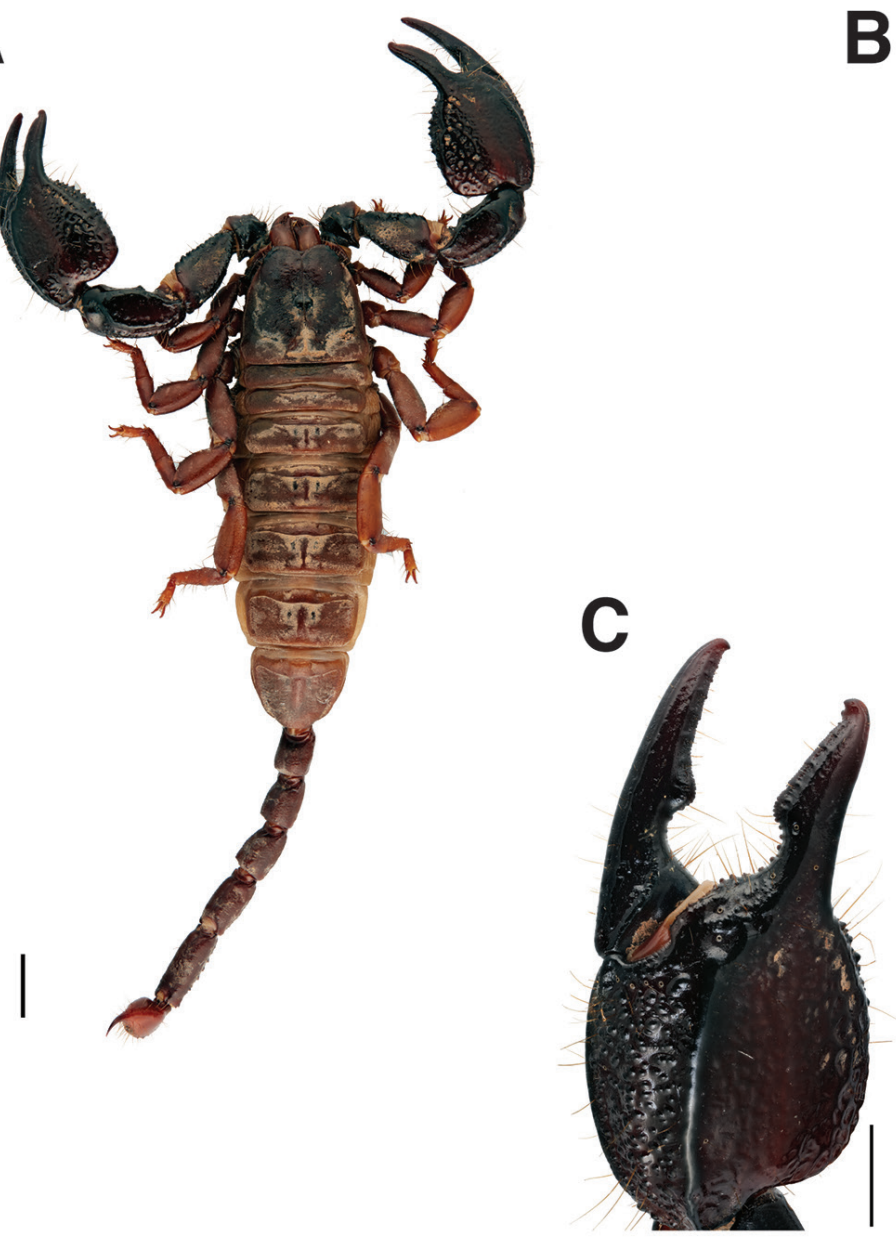

D

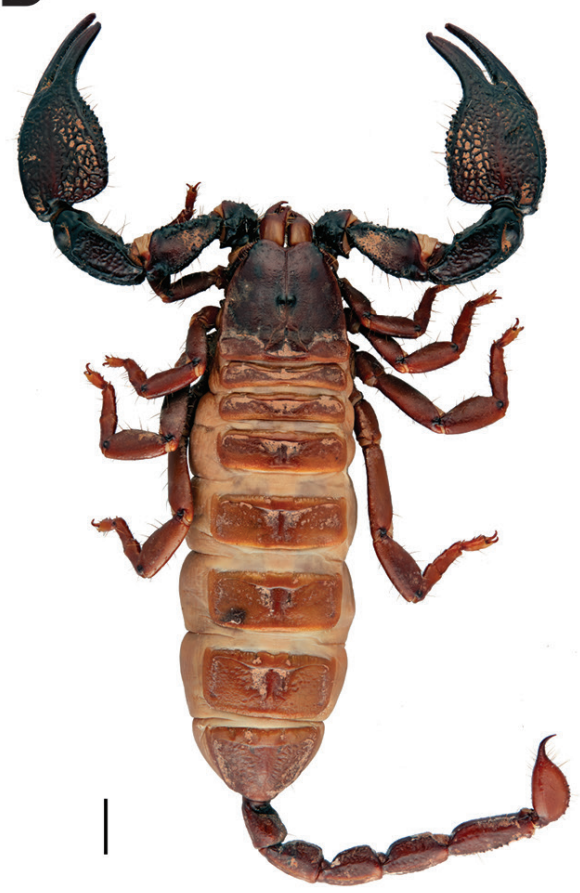

B

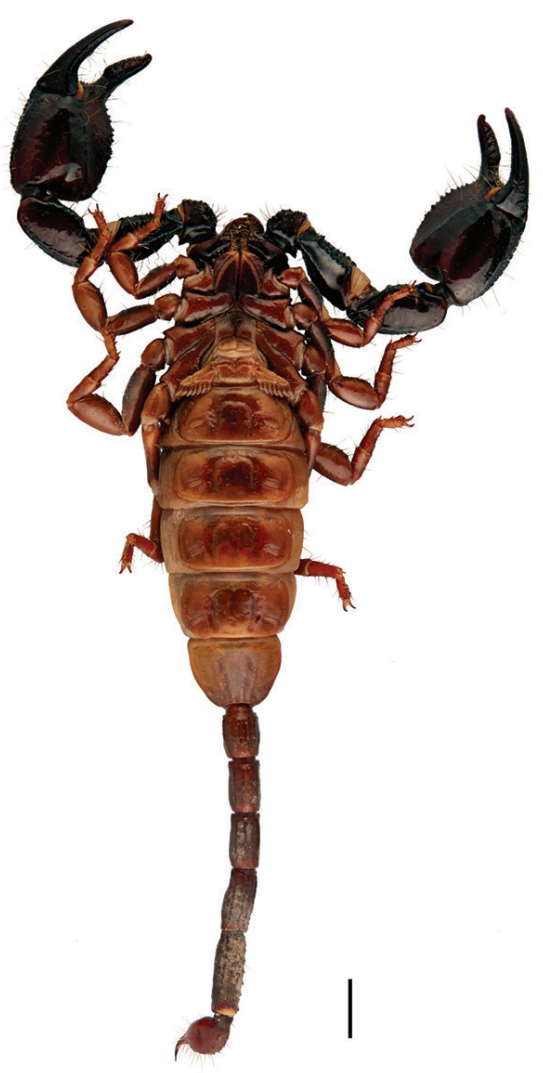

E

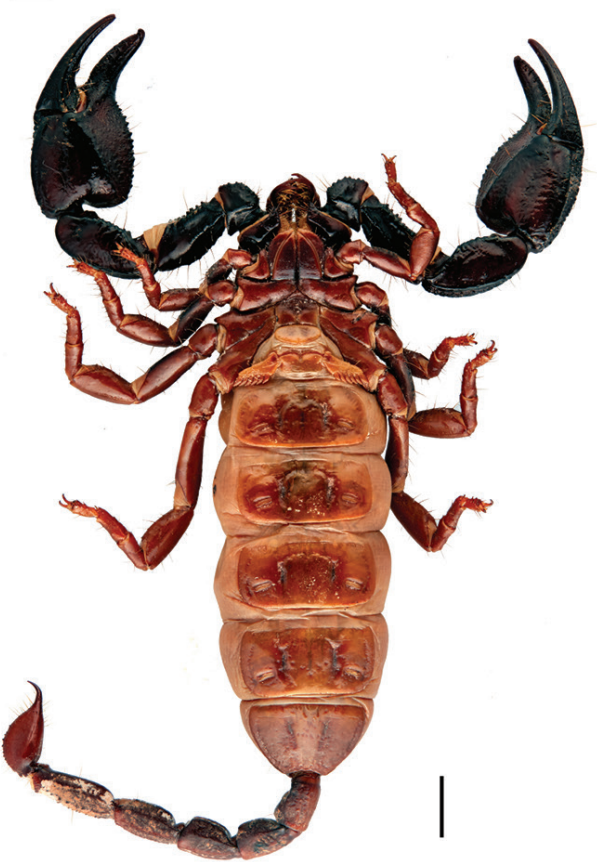

Figure 39. Opisthacanthus transvaalicus ochripes Kraepelin, 1911 [= Opisthacanthus validus Thorell, 1876], male lectotype (AC), female paralectotype (D-F): A, D dorsal aspect of habitus $\mathbf{B}, \mathbf{E}$ ventral aspect of habitus $\mathbf{C}, \mathbf{F}$ retrolateral aspect of chela illustrating dentate margins of fingers. Scale bars: $10 \mathrm{~mm}(\mathbf{A}-\mathbf{B}, \mathbf{D}-\mathbf{E}), 5 \mathrm{~mm}(\mathbf{C}, \mathbf{F})$. 
A

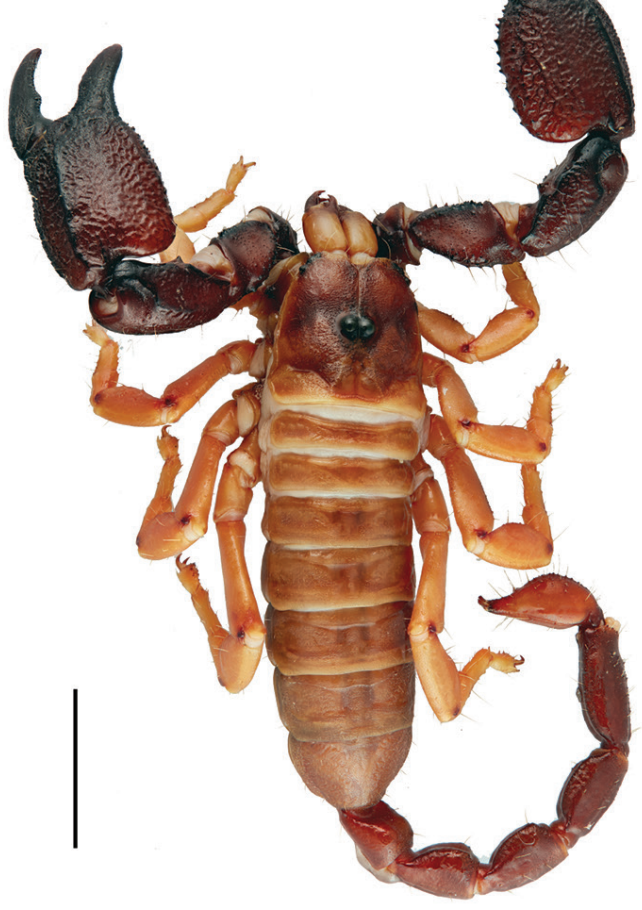

B

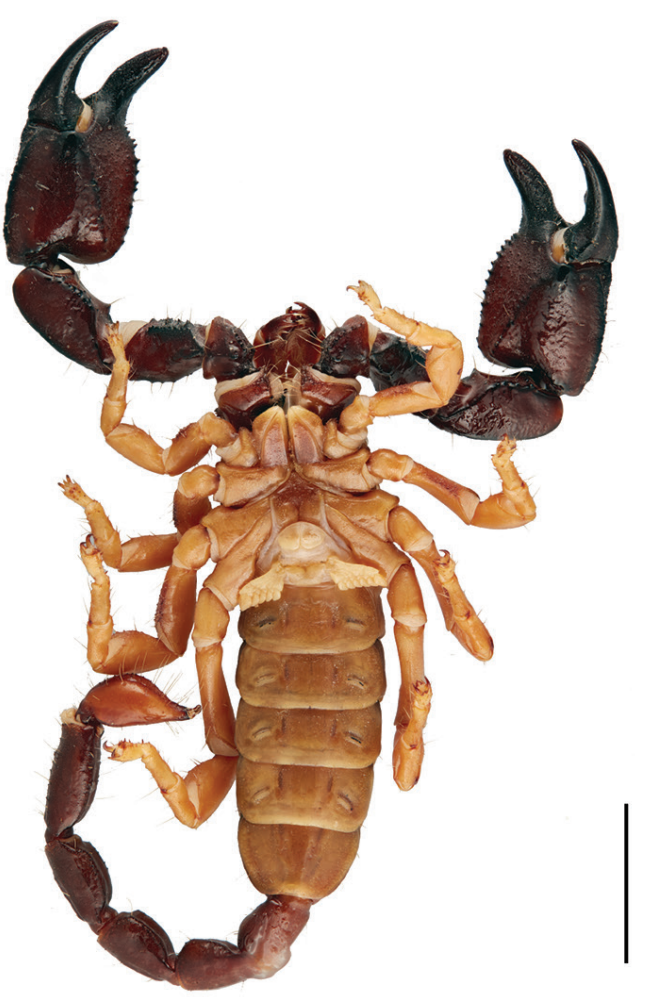

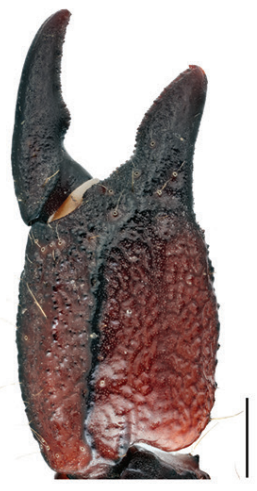

D
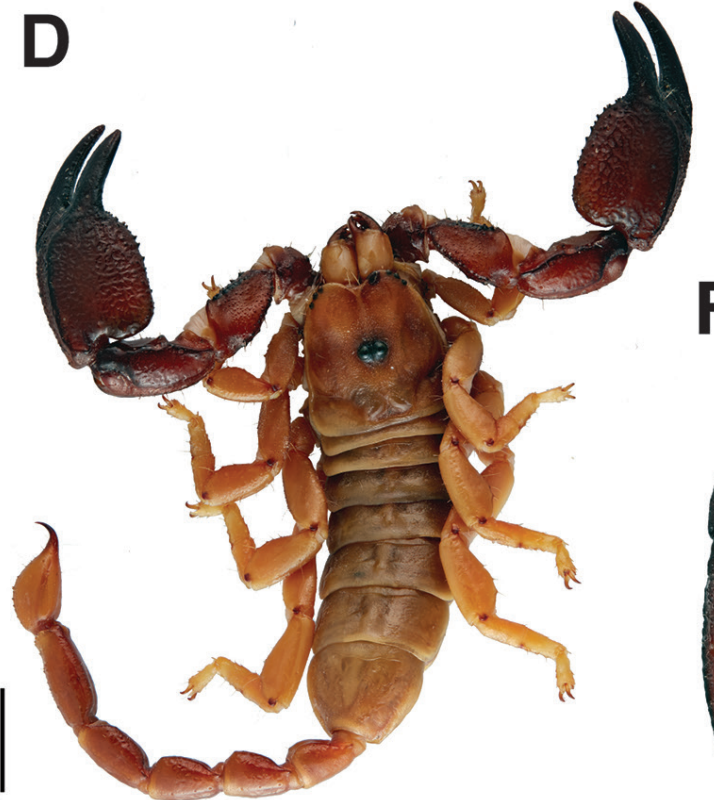

Figure 40. Opisthacanthus africanus pallidus Lourenço, 2003, male paratype (A-C), female holotype (D-F): A, D dorsal aspect of habitus $\mathbf{B}, \mathbf{E}$ ventral aspect of habitus $\mathbf{C}, \mathbf{F}$ retrolateral aspect of chela illustrating dentate margins of fingers. Scale bars: $10 \mathrm{~mm}$ (A-B, D-E), $5 \mathrm{~mm}(\mathbf{C}, \mathbf{F})$.

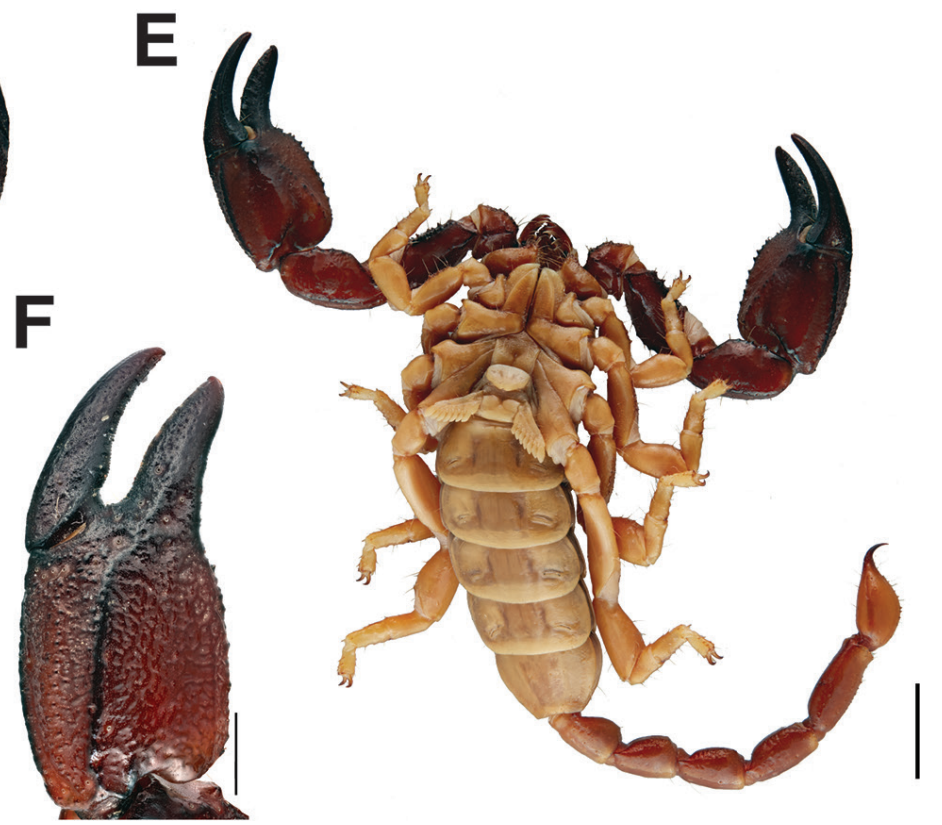




\section{Opisthacanthus transvaalicus}

Fig. 41

Opisthacanthus transvaalicus Kraepelin, 1911: 77, 82-83

Current senior synonym. Opisthacanthus (Nepabellus) validus Thorell, 1876 [synonymized by Lourenço 1987: 905]

Lectotype. (Fig. 41A-C) $\widehat{\partial}$ (ZMH-A0001099), [South Africa], Transvaal, 11.04.1909, Museum Amsterdam don.

Paralectotypes. $2 \hat{\sigma}, 1$ (Fig. 41D-E, ZMH-A0001098), 3 ๆ, 2 juveniles (ZMH-A0001565), same data as lectotype.

Remarks. A male from the syntype series is designated here as lectotype and the remaining specimens as paralectotypes. See paragraph on $O$. transvaalicus ochripes above.

Remarks on collector. The specimens were probably collected by S. Afer for the Amerstam Museum. No further data are available.

\section{Genus Palaeocheloctonus Lourenço, 1996}

\section{Palaeocheloctonus pauliani}

Fig. 42

Palaeocheloctonus pauliani Lourenço, 1996: 37-38, fig. 95-104, 159, 161, 162

Current combination. Palaeocheloctonus pauliani Lourenço, 1996

Paratype. $1 \curvearrowright$ (ZMH-A00001064), Madagascar SudOuest [SW Madagascar], Province Tuléar, [Atsimo-Andrefana Region], Plateau Mahafaly, près de Behahitso

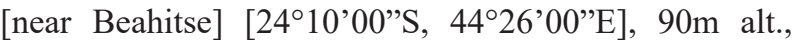
zone à dolines [sinkhole area], haut fourré arbustif à Euphorbes et Didièréacées [vine and shrub thicket with Euphorbia and Didiereaceae], chasse à vue [on sight collecting], sous bois mort et pierres [under logs and stones], 01.1966, P. Griveaud leg. (ZMH Eing. A75/98).

Remarks. The holotype and one paratype are deposited in the MNHN in Paris, and two additional paratypes are in the MHNG collections.

\section{Family Scorpionidae Latreille, 1802}

Type specimens belonging to 20 species are present at ZMH. The specimens for three species previously considered as types are reported here as non-type material.

\section{Genus Heterometrus Ehrenberg, 1828}

\section{Scorpio phipsonii}

Fig. 43

Scorpio phipsonii Pocock, 1893: 307-310

Current combination. Heterometrus phipsonii (Pocock, 1893)
Probably not type. $\widehat{~}(\mathrm{ZMH}-\mathrm{A} 000939)$, Indien [India], BMNH don, ded. VI.1894.

Remarks. Pocock (1893) reported several specimens from Madras, as well as one male from Madras and one female from Sheravoy Hills; both collected by Thurston. There is no evidence that the present specimen belongs to this material and we do not consider it part of the type series.

\section{Palamnaeus thorellii}

Fig. 44

Palamnaeus thorellii Pocock, 1892: 40-41

Current combination. Heterometrus thorellii (Pocock, 1892) [Synonymized by Couzijn 1981: 117 to Heterometrus bengalensis (C. L. Koch, 1841), removed from synonymy by Kovařík (2004: 44)]

Syntypes. $1 \curvearrowright$ (Fig. 44A-B), 1 (Fig. 44C-D, ZMH-A0002219), [Myanmar], [Bago Region], Indien?, Tharrawaddy [17³9'14'N, 9547'17'E], VI.1897, Eugene William Oates leg., BMNH don.

Remarks. Pocock described Palamnaeus thorelli based on a large series of specimens collected by E. W. Oates in several regions of Burma (now Myanmar) (Pocock 1892: 39 “.....literally many hundred examples of a species of Palamnaeus..."). The syntypes in the ZMH are a gift from the BMNH. According to Fet (2000c), only five syntypes (two males, three females) are located in the BMNH, but it is likely that more material is present at the BMNH.

Remarks on collector. Eugene William Oates (1845-1911) was an English naturalist, mostly interested in birds. In 1867, he was hired by the Public Works Department in India and sent to Burma where he remained until 1899, returning twice to England in the meantime (1881-1883, 1888-1890) (Anonymous 1912). During his time in Burma, he made large zoological collections, mostly of birds, that were later acquired by the British Museum.

\section{Heterometrus ubicki}

Fig. 45

Heterometrus ubicki Kovařík, 2004: 46, 53, fig. 30, tab. 1-3

Current combination. Heterometrus ubicki Kovařík, 2004.

Paratype. + (ZMH-A0000945), India, Pondichery, Kāraikāl [1055'00”N, 7950'00”E], 10.2003-05.2004, T.R.S.N. leg., F. Kovař́k leg.

Remarks. The original type series was deposited in František Kovařík's personal collection (FKCP) and the California Academy of Science (CAS). The present paratype was donated to the $\mathrm{ZMH}$ by Kovařík from his private collection. 

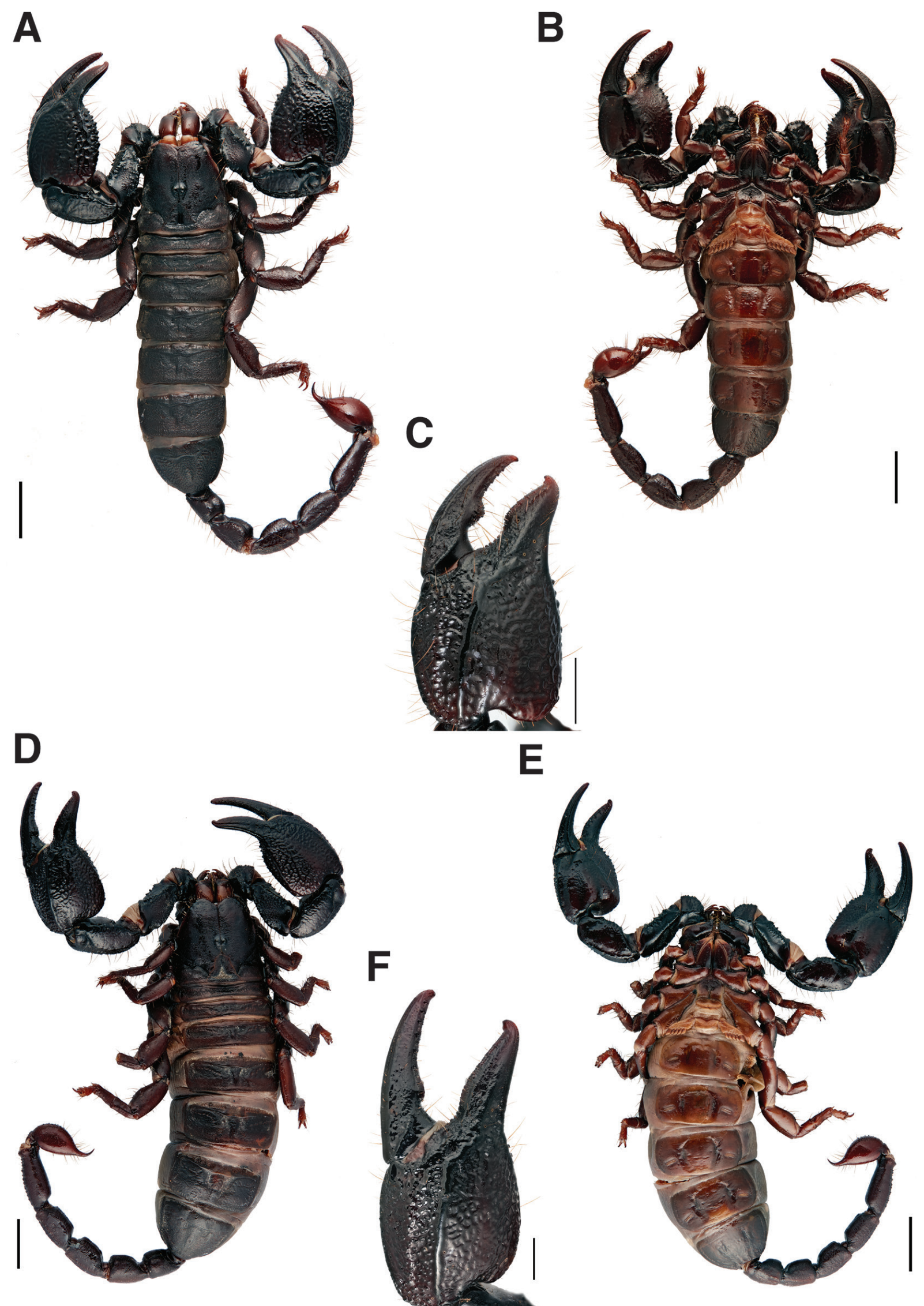

Figure 41. Opisthacanthus transvaalicus Kraepelin, 1911 [= Opisthacanthus validus Thorell, 1876], male lectotype (A-C), female paralectotype (D-F): A, D dorsal aspect of habitus B, $\mathbf{E}$ ventral aspect of habitus $\mathbf{C}, \mathbf{F}$ retrolateral aspect of chela illustrating dentate margins of fingers. Scale bars: $10 \mathrm{~mm}(\mathbf{A}-\mathbf{B}, \mathbf{D}-\mathbf{E}), 5 \mathrm{~mm}(\mathbf{C}, \mathbf{F})$. 


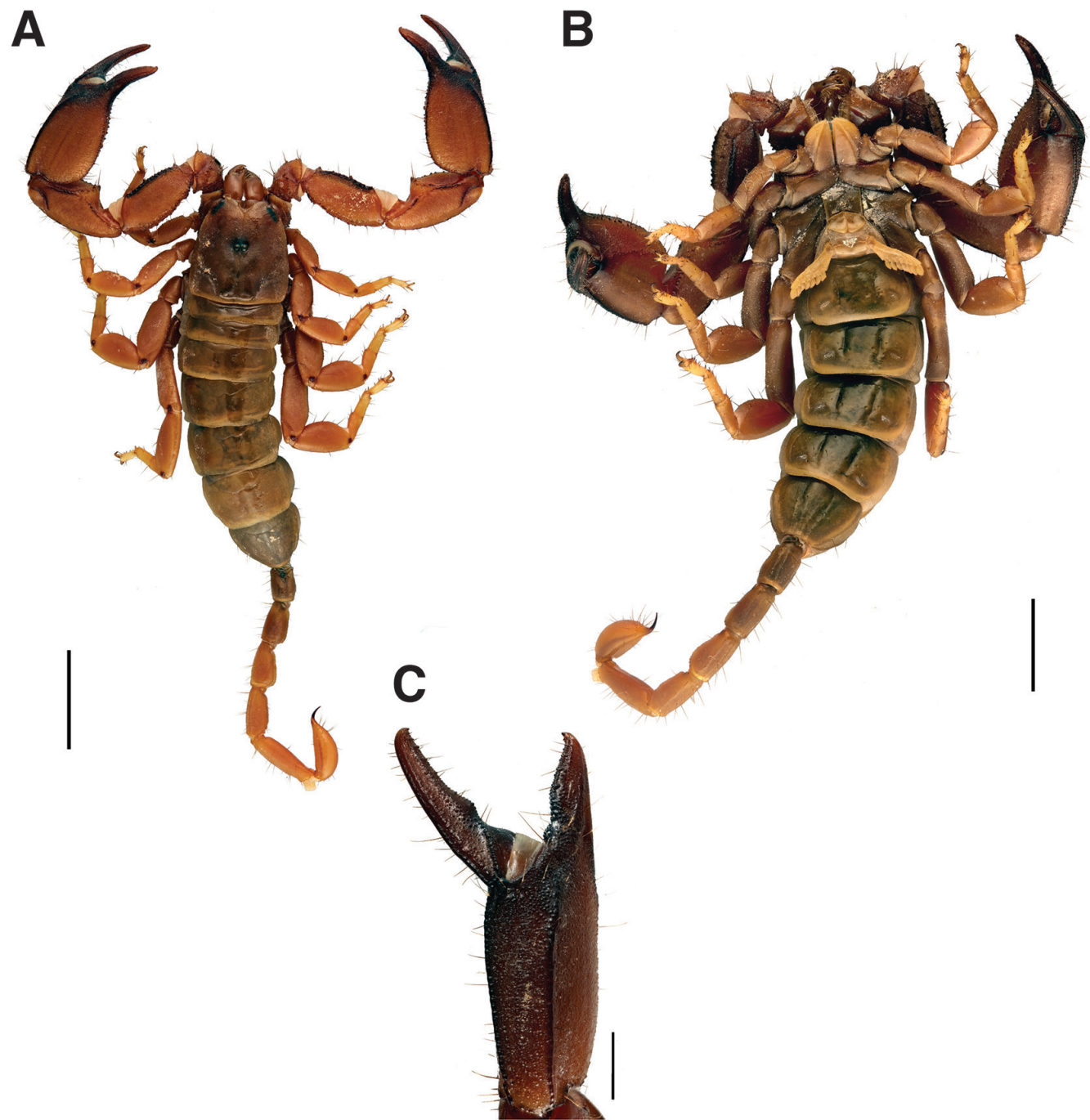

Figure 42. Palaeocheloctonus pauliani Lourenço, 1996, male paratype, habitus A dorsal aspect $\mathbf{B}$ ventral aspect $\mathbf{C}$ retrolateral aspect of chela illustrating dentate margins of fingers. Scale bars: $10 \mathrm{~mm}(\mathbf{A}-\mathbf{B}), 5 \mathrm{~mm}(\mathbf{C})$.

Genus Opistophthalmus C. L. Koch, 1837

\section{Opisthophthalmus adustus}

Fig. 46

Opisthophthalmus adustus Kraepelin, 1908d: 260-261

Current combination. Opistophthalmus adustus Kraepelin, 1908

Lectotype. (Fig. 46C-D) + (ZMH-A0000910), Deutsch Südwestafrika [Namibia], Friedrich Fülleborn leg., ded. 04.1908.

Paralectotype. (Fig. 46A-B) $\hat{\sigma}$ (ZMH-A0000910), same data as lectotype.

Remarks. The specimens were designated lectotype and paralectotype respectively by Lamoral (1979: 675).

Remarks on collector. Friedrich Georg Hans Heinrich Fülleborn (1866-1933) was a medical doctor from West Prussia (now Poland) who specialized in tropical medicine and parasitology. From 1896 onwards, he was a military physician assigned to the Schutztruppe in German East Africa (now Namibia) (Leipoldt 2006). In 1898-1900, he participated in the Nyassa- und Kingagebirgs Expedition to the southern part of the colony where he conducted anthropological and ethnographic research (Fülleborn 1906; J.W.G. 1907). In 1901, he returned to Germany and was appointed Director of the Department of Tropical Hygiene and Tropical Medicine at the Hamburg Institute for Marine and Tropical Diseases.

\section{Opisthophthalmus calvus}

Opisthophthalmus calvus L. Koch, 1867: 233-234

Current senior synonym. Opistophthalmus latimanus C. L. Koch, 1841 [synonymized by Purcell 1899: 159-161]

Holotype. ㅇ (ZMH-A00001867), Südafrika, Museum Godeffroy (2248).

Remarks. The holotype could not be examined nor photographed as it was on loan at the time of writing. 

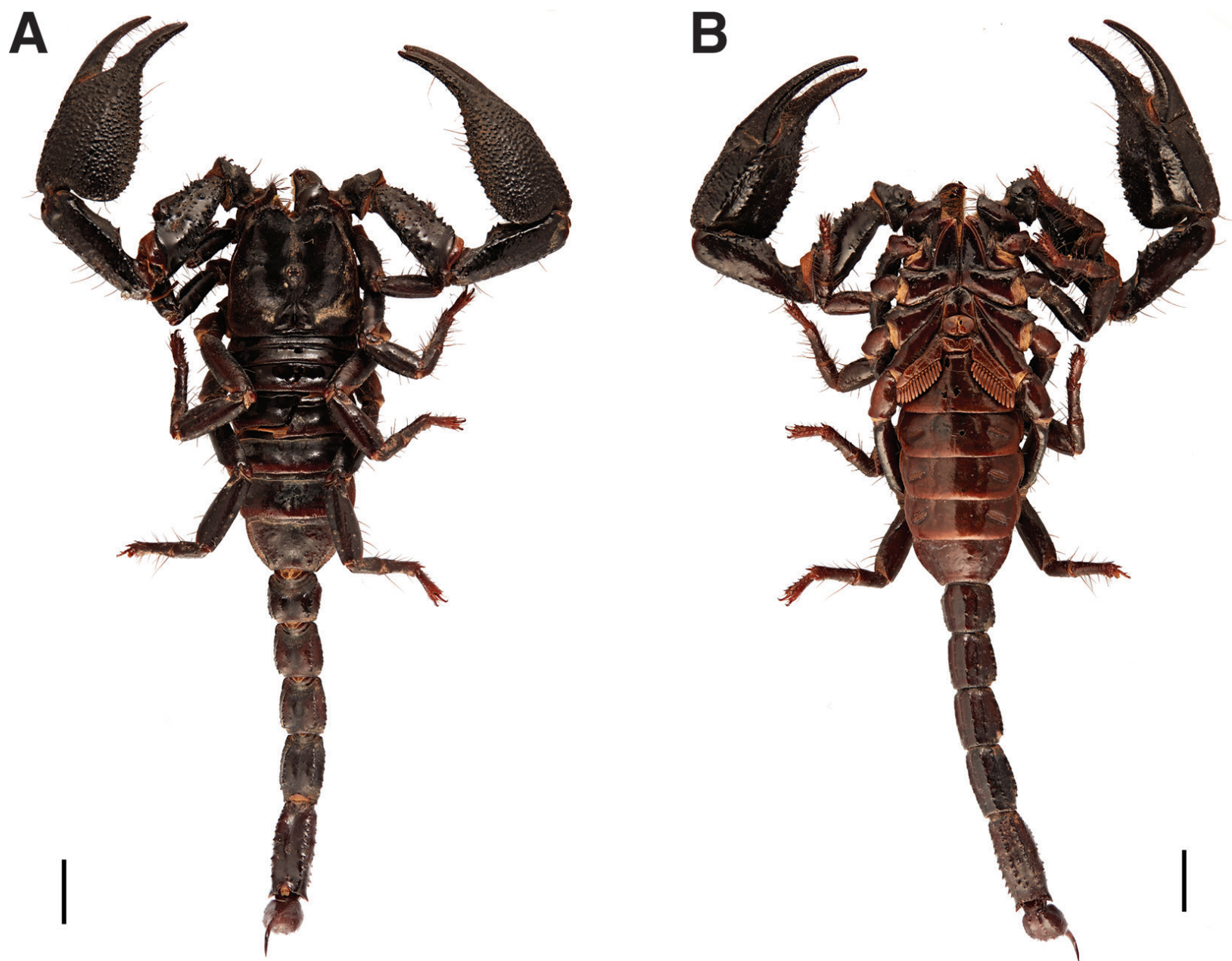

Figure 43. Scorpio phipsonii Pocock, 1893 [= Heterometrus phipsonii (Pocock,1893)], male, habitus A dorsal aspect B ventral aspect. Scale bars: $10 \mathrm{~mm}$.

The data provided here were taken from Weidner (1959) and Fet (2000c). Prendini (2001: 29) confirmed the synonymy of $O$. calvus with $O$. latimanus after examination of the present holotype.

\section{Opisthophthalmus crassimanus}

Fig. 47

Opisthophthalmus crassimanus Purcell, 1899: 164-168

Current combination. Opistophthalmus crassimanus Purcell, 1899

Syntypes. $1 \precsim$ (Fig. 47A-B), 1 (Fig. 47C-D), 1 , 1 subadult $\$$, 1 juvenile (ZMH-A0001086, ZMH-A0001087, ZMH-A0001088), [South Africa], Cape Colony [Northern Cape], Namaqualand [Namakwa District], Jackals Water [Jakkalswater near Springbok] [29`38'19'S, 1748'29”'E], 02.1897, M. Rudolf Schlechter leg.

Remarks. A complete revision of the genus Opistophthalmus is being prepared (Prendini in prep.) and we decided not to designate lectotype and paralectotype among the type specimens in order to avoid interferencing with this ongoing project.
Remarks on collector. Rudolf Schlechter (18721925) was a German botanist who wrote several works on orchids. He collected more than 12 thousands botanical specimens in South Africa between 1891 and 1898 (Jessop 1964).

\section{Opisthophthalmus fossor}

Fig. 48

Opisthophthalmus fossor Purcell, 1898: 9-12, figs. 4, 4a

Current combination. Opistophthalmus fossor Purcell, 1898

Syntypes. $1 \hat{\jmath}$ (Fig. 48A-B), 1 (Fig. 48C-D) (ZMH-A0000935), [South Africa], Cap Colonie [Western Cape], Worcester division, Schlanghoek [Slanghoek] [3338'00”S, 19¹2'00”E], [R. Francke leg.], F. Purcell don., ded. 27.12.1898.

Remarks. Among the type material, Purcell (1898) listed two males and two females from Schlanghoek. The specimens in the ZMH are part of this series and the remaining specimens are in the South African Museum (Cape Town). 

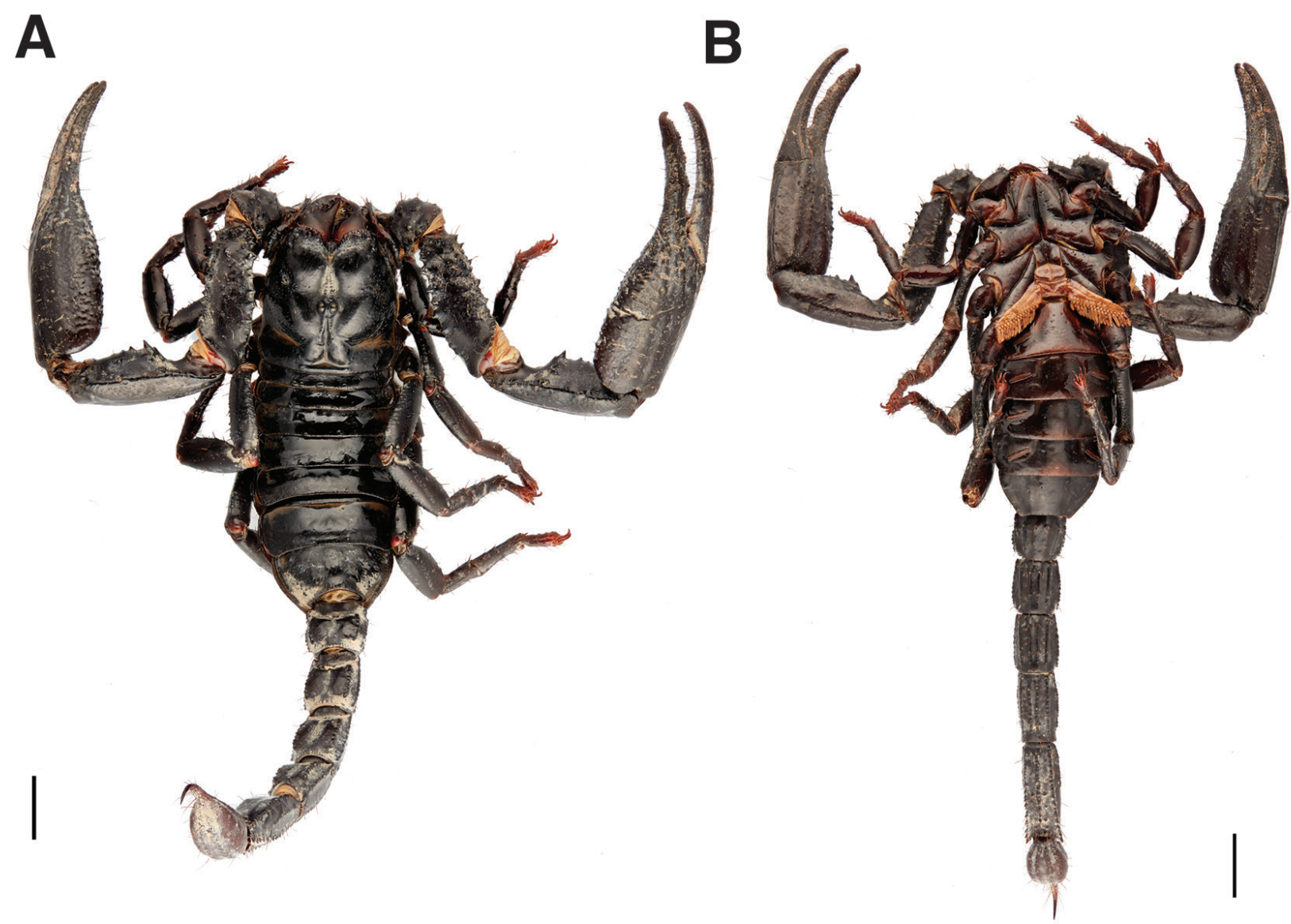

C

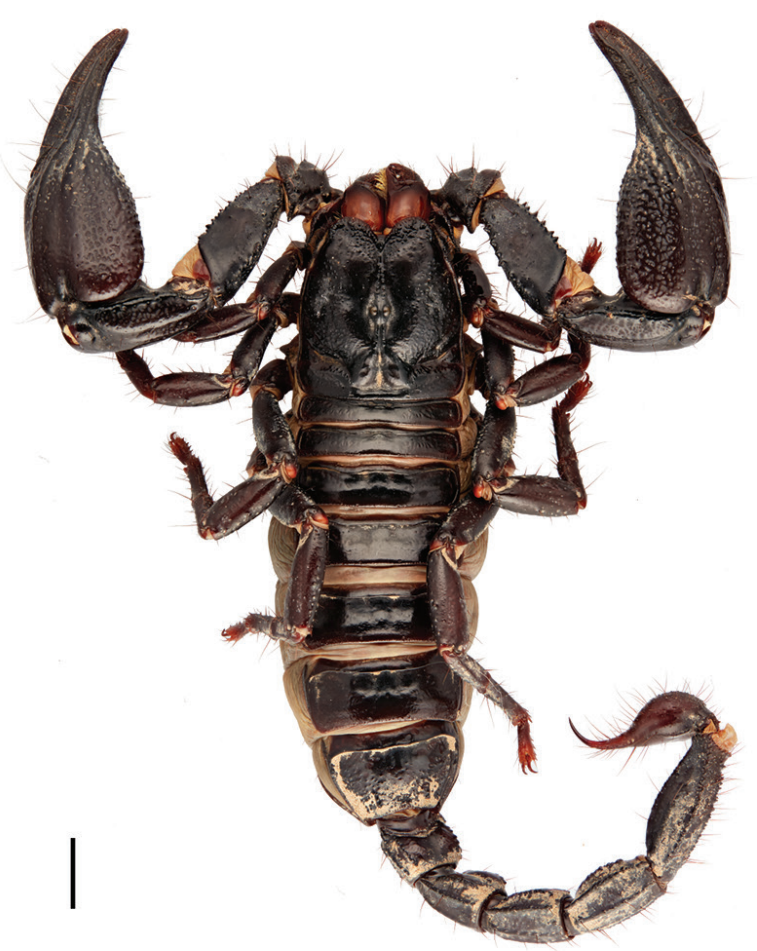

D

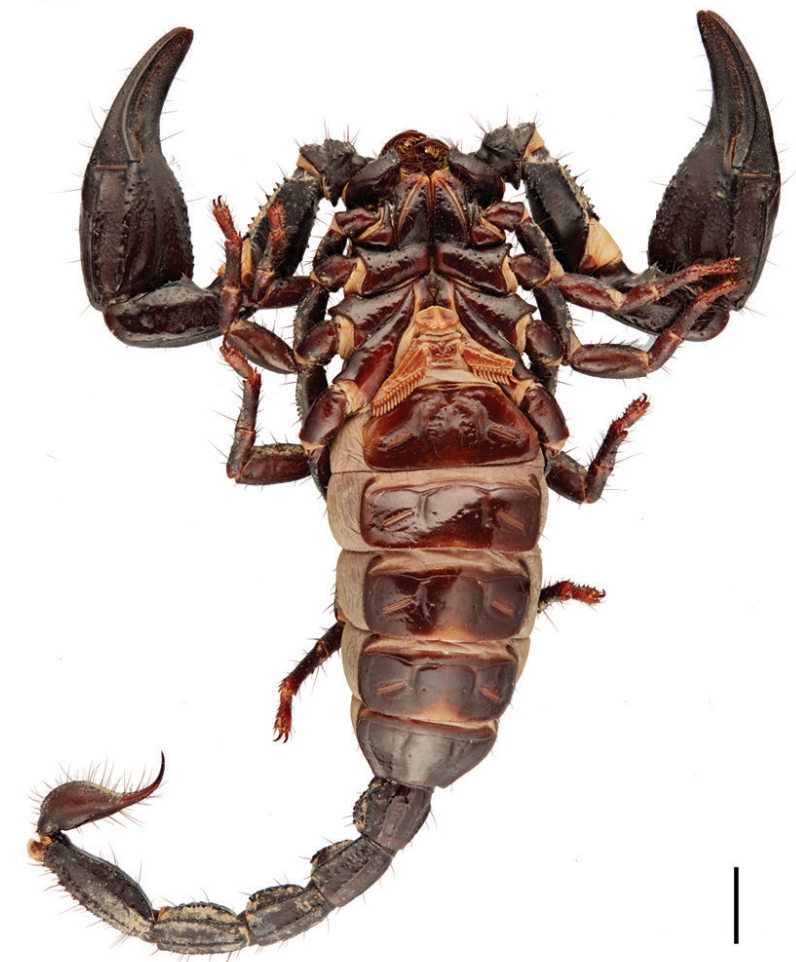

Figure 44. Palamneus thorellii Pocock, 1892 [= Heterometrus bengalensis (C. L. Koch, 1841)], male syntype (A-B), female syntype (C-D): A, C dorsal aspect of habitus B, D ventral aspect of habitus. Scale bars: $10 \mathrm{~mm}$. 
A

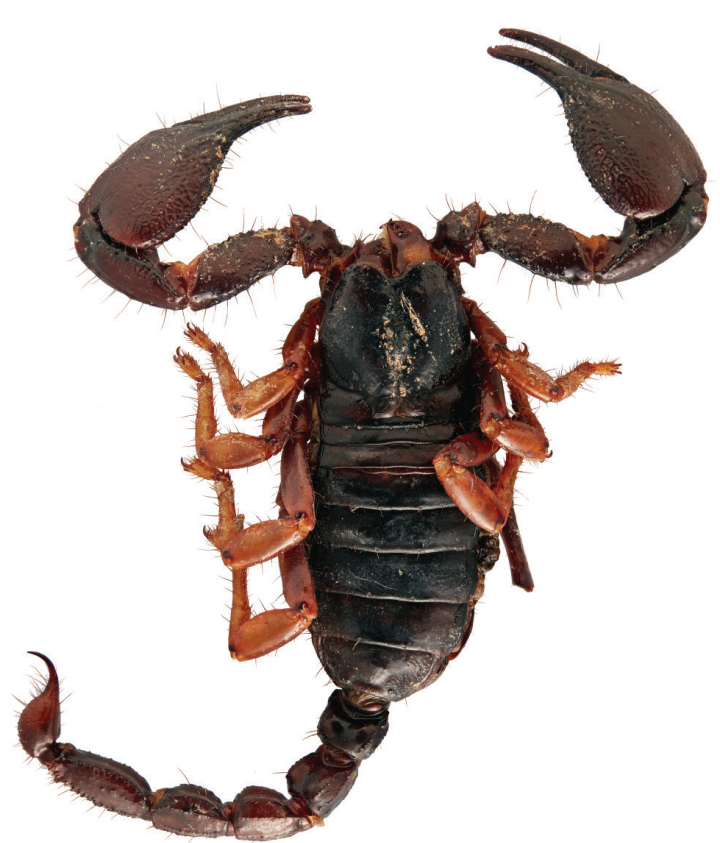

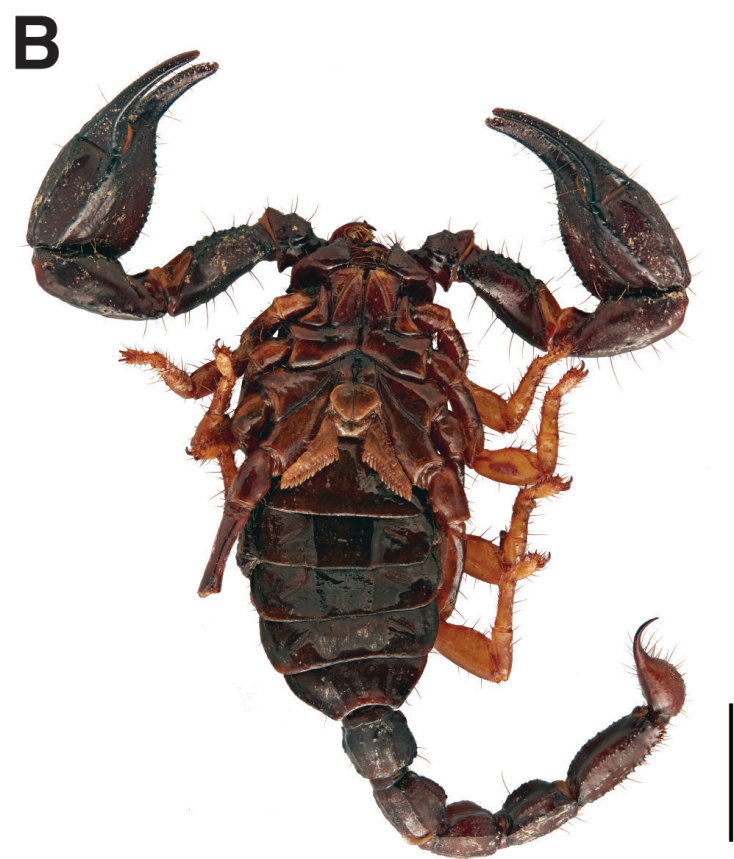

Figure 45. Heterometrus ubicki Kovarik, 2004, female paratype, habitus A dorsal aspect B ventral aspect. Scale bars: $10 \mathrm{~mm}$.

\section{Opisthophthalmus fuscipes}

Fig. 49

Opisthophthalmus fuscipes Purcell, 1898: 20-23

Current combination. Opistophthalmus fuscipes Purcell, 1898

Paralectotypes. 1 ๙ (Fig. 49A-B), 1 (Fig. 49CD) (ZMH-A0001865), [South Africa], Kapland [Western Cape], Tulbagh Division, near the railway station [33 $3^{\circ} 19^{\prime} 13^{\prime}$ 'S, $19^{\circ} 05^{\prime} 59^{\prime}$ 'E] Tulbagh Road at the foot of the Waterfall Mountains, F. Purcell leg.

Remarks. Purcell (1899: 149-150) considered $O$. fuscipes as a subspecies of Opistophthalmus capensis (Herbst, 1800). Prendini (2001) subsequently highlighted consistent diagnostic differences between the two taxa and thus reinstated $O$. fuscipes as a species. Prendini (2001) also designated lectotype and paralectotype from the syntype series housed in the SAMC collection but did not cite the present specimens. Purcell (1898) mentioned that numerous specimens were part of the type series without giving a precise number. Given that the data of the present specimens match that of the original description, they are considered as paralectotypes.

\section{Opisthophthalmus granicauda}

Fig. 50A-B

Opisthophthalmus granicauda Purcell, 1898: 14-16

Current combination. Opistophthalmus granicauda Purcell, 1898
Paralectotype. $\hat{\sigma}$ (ZMH-A0000929), [South Africa], [Northern Cape], Namaqualand, Port Nolloth [29 $15^{\prime} 06^{\prime}$ 'S, $\left.16^{\circ} 52^{\prime} 10^{\prime \prime} \mathrm{E}\right]$, F. Purcell leg., ded. 27.XII.1898.

Remarks. Purcell (1898) listed 12 specimens (11 males, 1 female) from Port Nolloth which form the type series. This series is held by the SAMC and the present specimen was donated to the $\mathrm{ZMH}$ from this material.

\section{Opisthophthalmus intercedens}

Fig. 50C-D

Opisthophthalmus intercedens Kraepelin, 1908d: 262, 265

Current combination. Opistophthalmus intercedens Kraepelin, 1908

Paralectotype. 1 juvenile (ZMH-A0002215), [Namibia], Kl. Namaland, [Karas Region], Kubub [2644‘00“S, $16^{\circ} 17^{\circ} 00^{\prime \prime E}$ ], Leonhard Schultze leg., ded 06.1907.

Remarks. Kraepelin (1908d) mentioned two juveniles and a subadult female as type specimens. A female and one juvenile are present in the $\mathrm{ZMB}$ collections and these were designated as lectotype (ZMB/Arach-14973) and paralectotype (ZMB/Arach-14973) by Lamoral (1979: 723).

Remarks on collector. Leonhard Sigmund Schultze (1872-1955) was a German ethnologist and zoologist. He led a major expedition to Namibia in 1903-1905 (Schultze 1907) and between March and May 1904. The party visited the area between Angra Pequena and Kubub (Schultze 1907, 1908 [see map]; also see Harms and Dupérré 2018 for details). After returning to Germany, he was Director of the Museum of Ethnology from 1913 to 1937. 
A

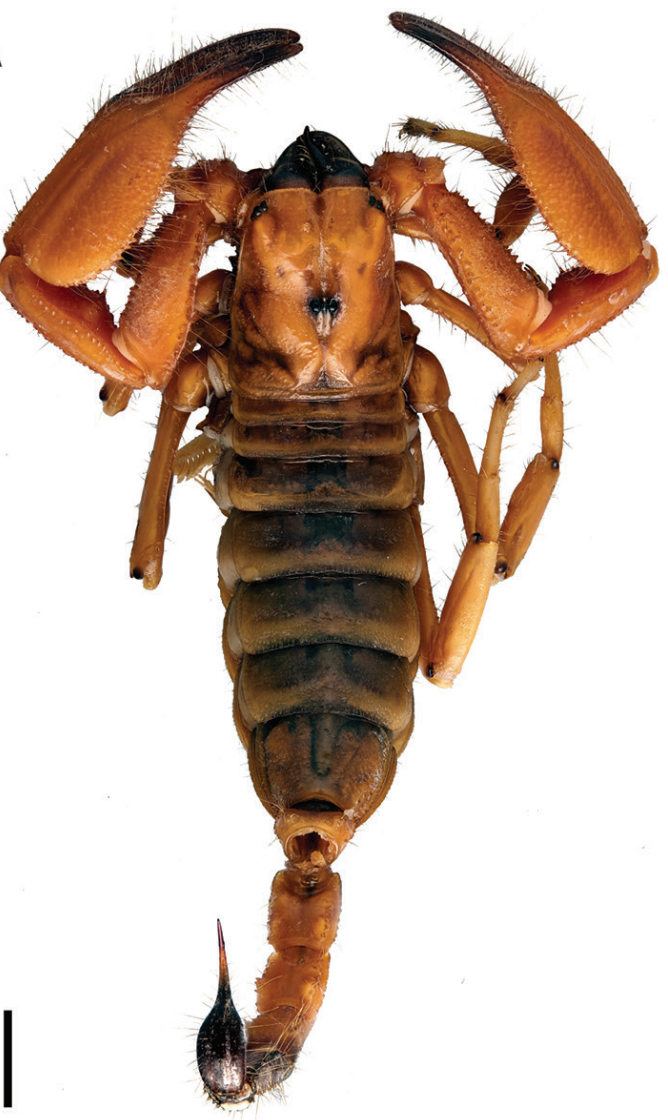

C

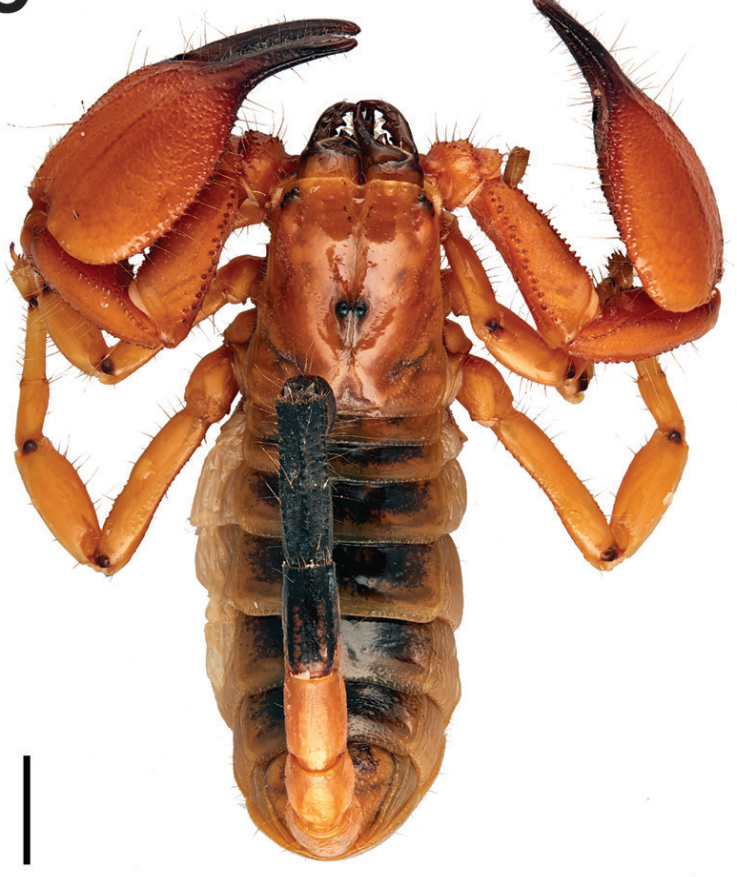

B

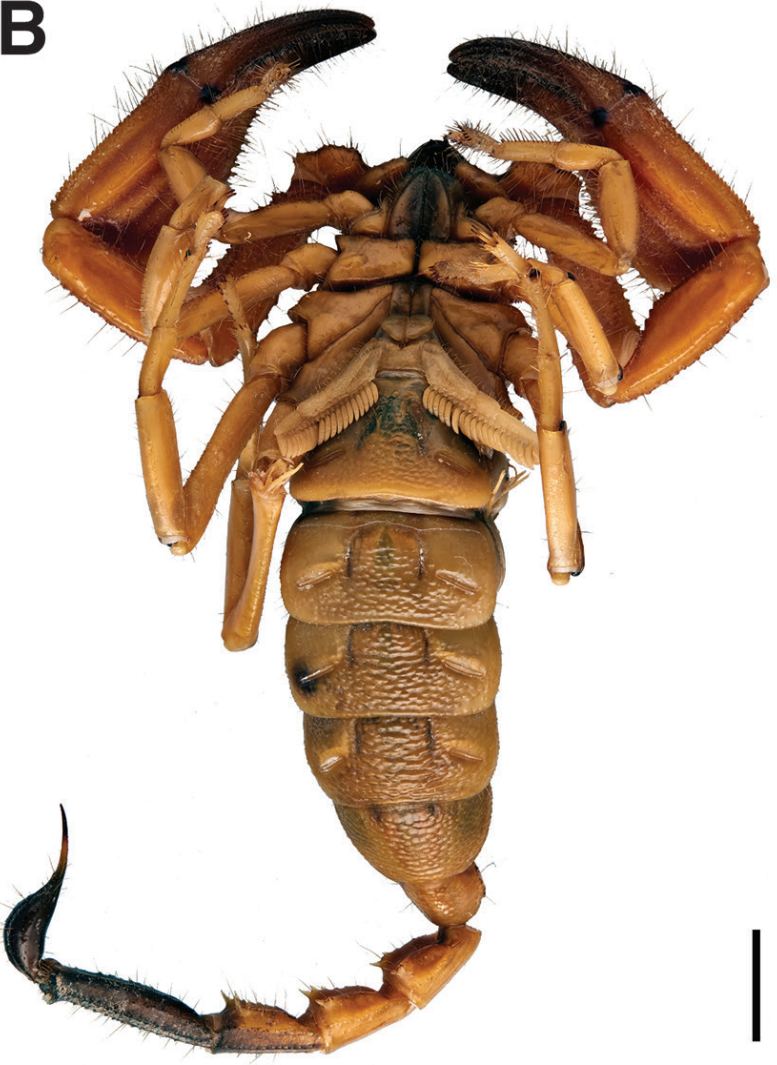

D

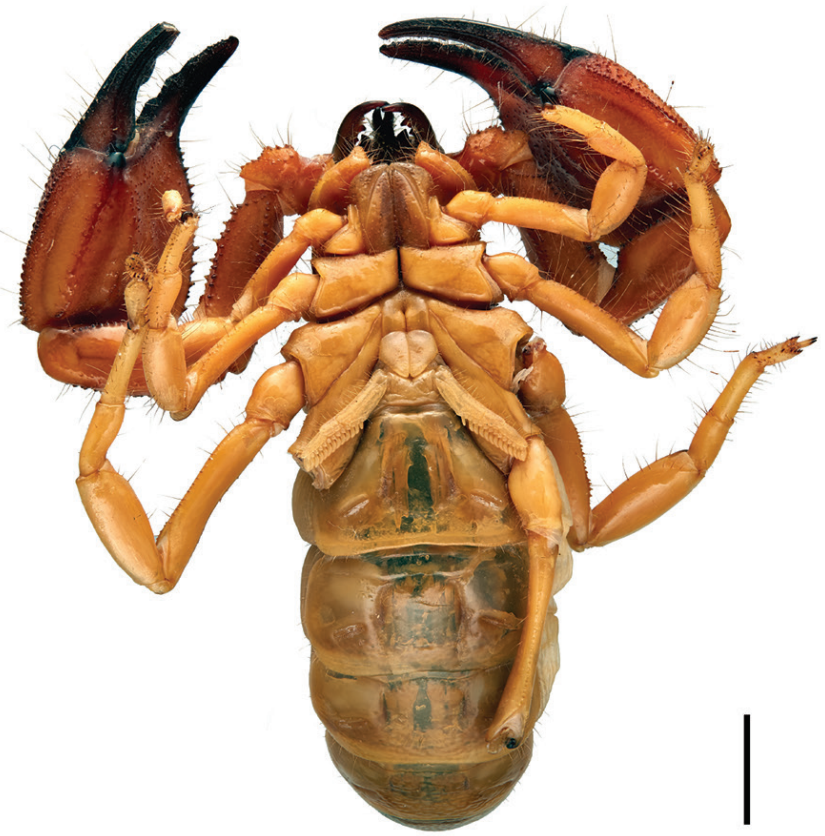

Figure 46. Opistophthalmus adustus Kraepelin, 1908, male paralectotype (A-B), female lectotype (C-D): A, C dorsal aspect of habitus B, D ventral aspect of habitus. Scale bars: $10 \mathrm{~mm}$. 
A

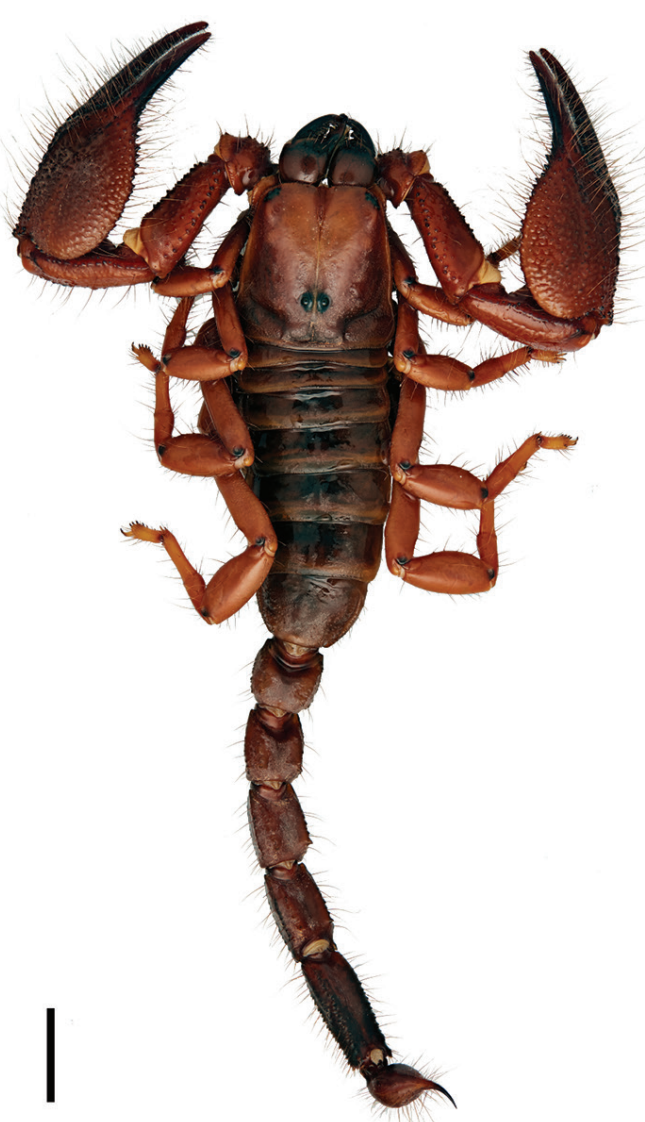

C

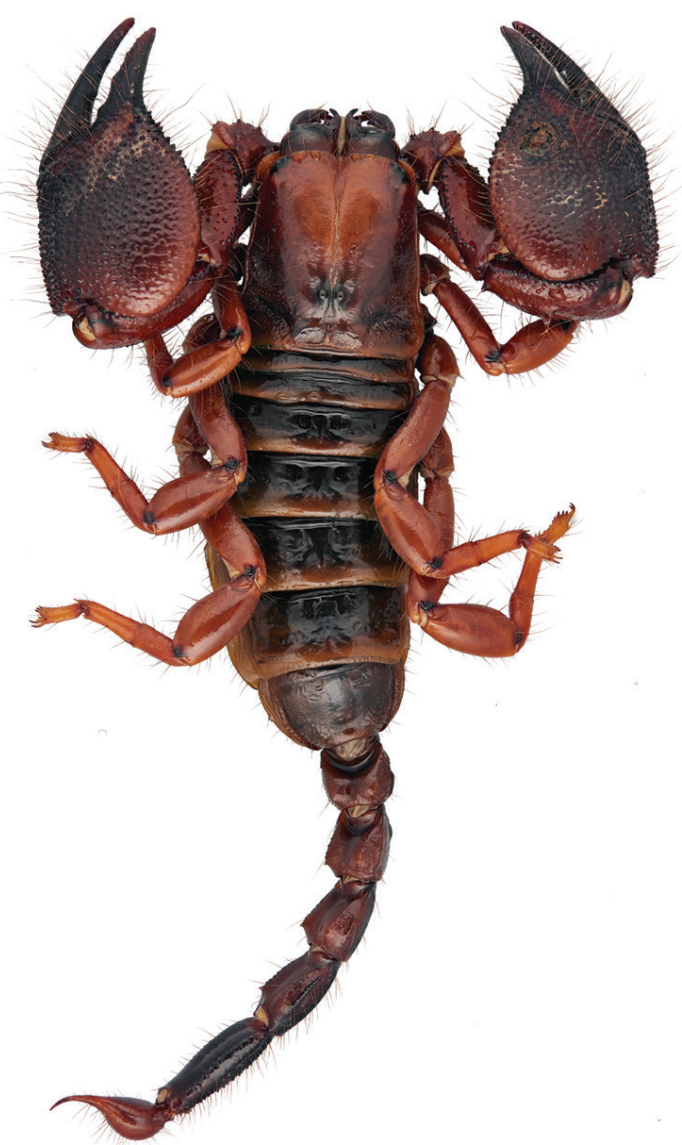

B

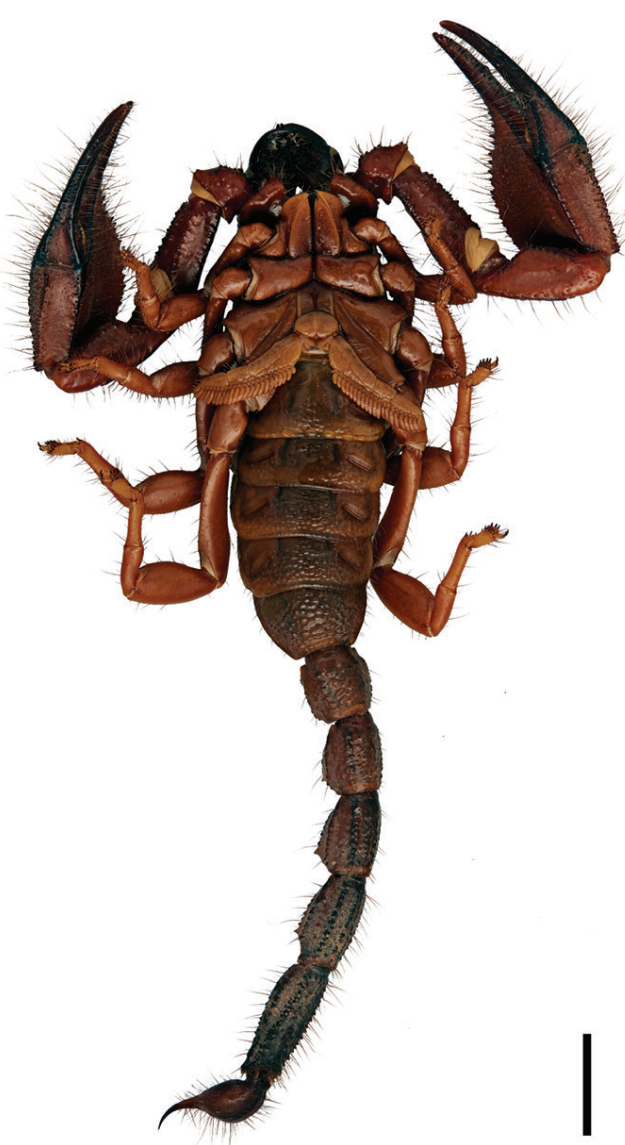

D

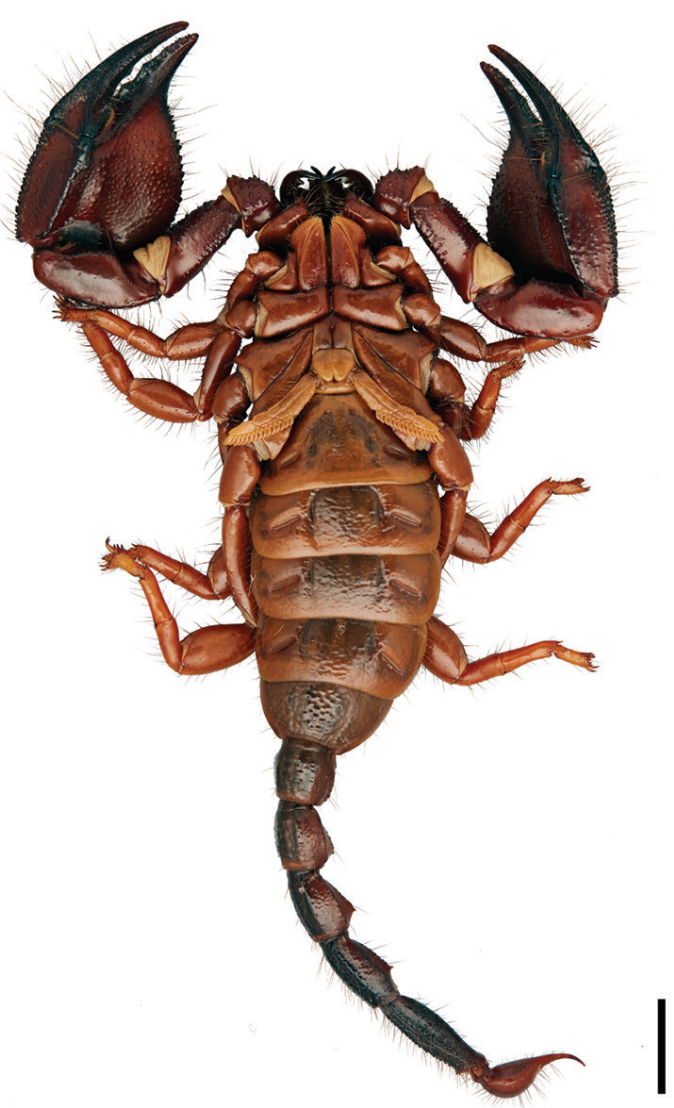

Figure 47. Opistophthalmus crassimanus Purcell, 1899, male syntype (A-B), female syntype (C-D): A, C dorsal aspect of habitus B, D ventral aspect of habitus. Scale bars: $10 \mathrm{~mm}$. 

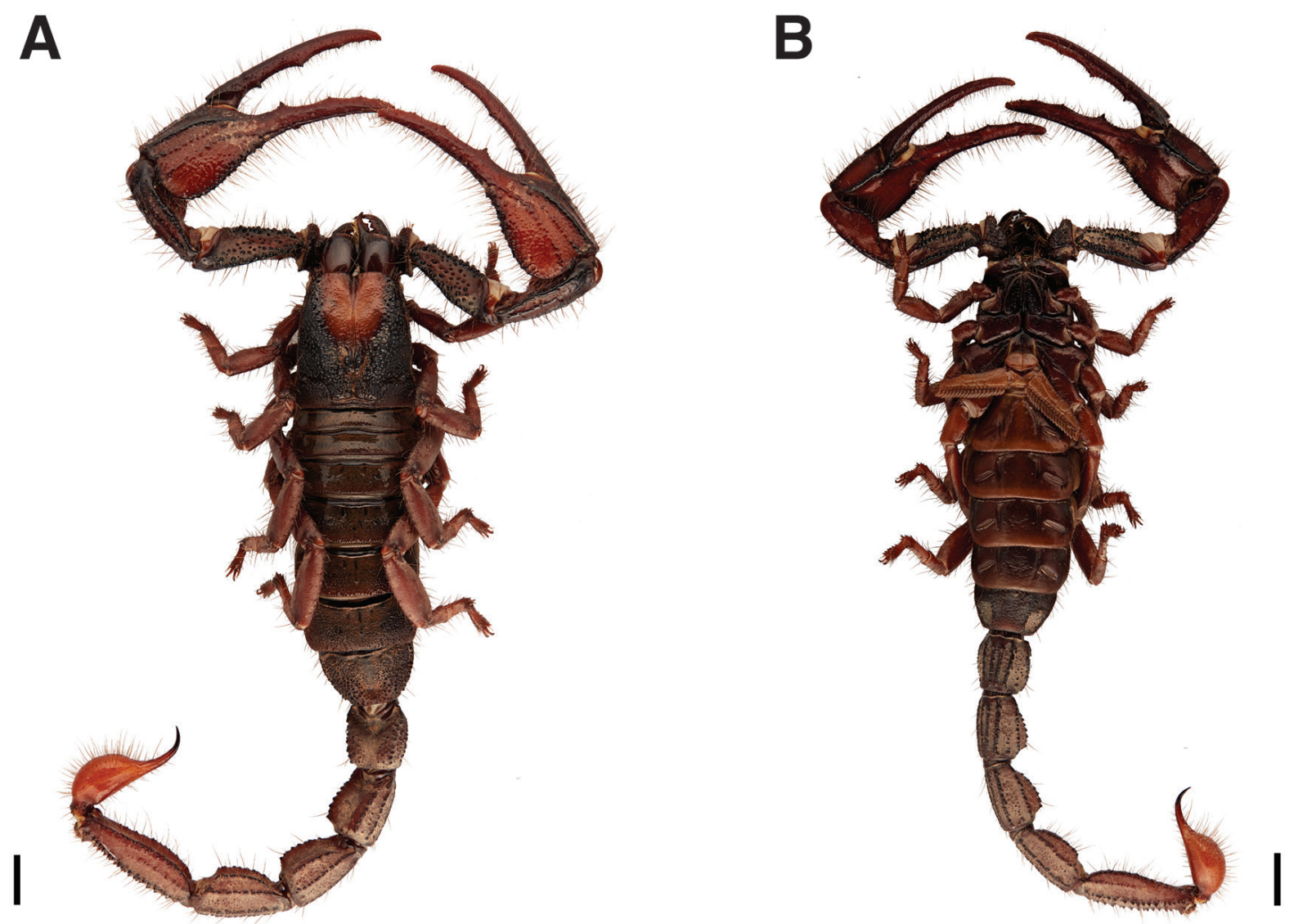

C
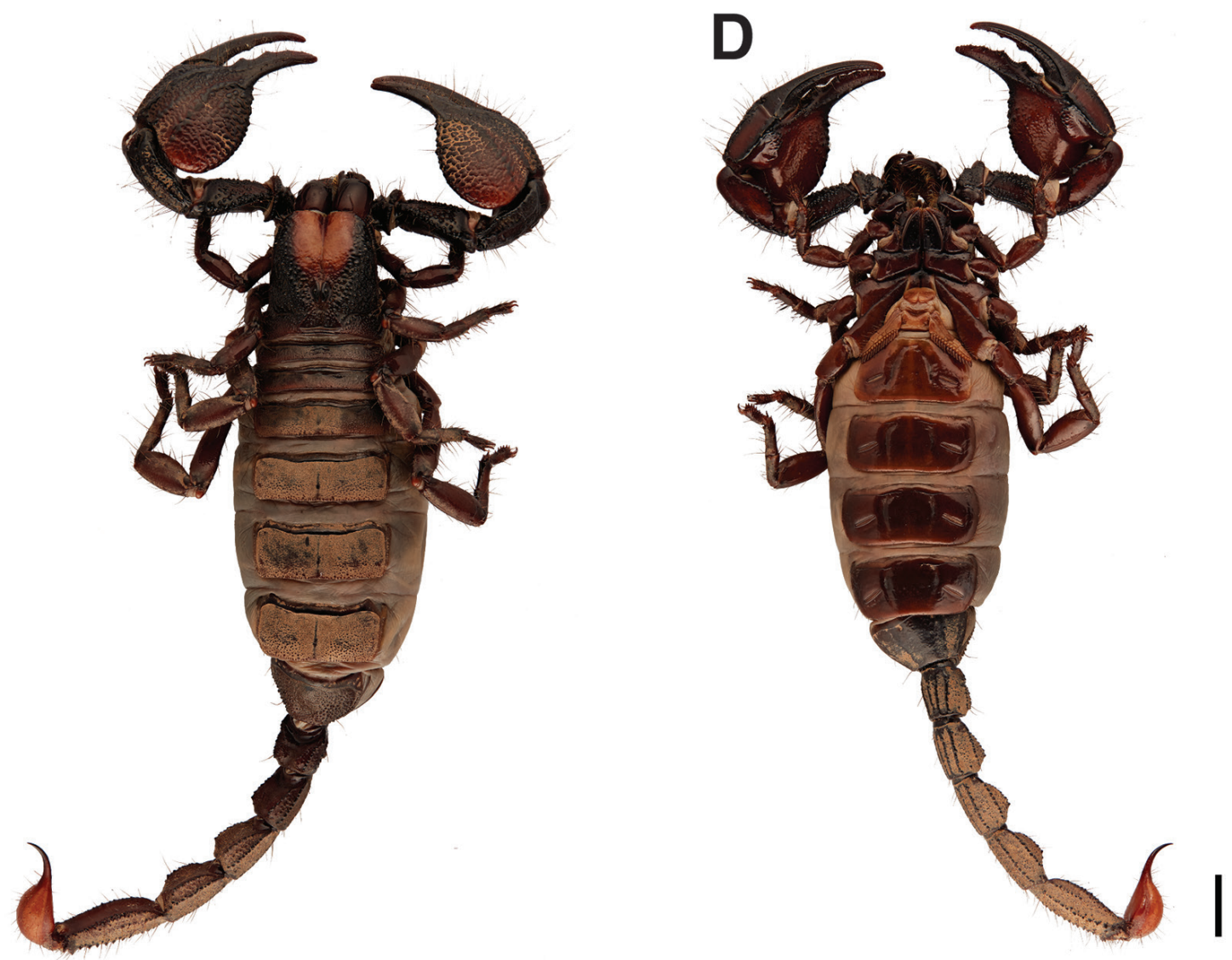

Figure 48. Opistophthalmus fossor Purcell, 1898, male syntype (A-B), female syntype (C-D): A, C dorsal aspect of habitus B, D ventral aspect of habitus. Scale bars: $10 \mathrm{~mm}$. 
A

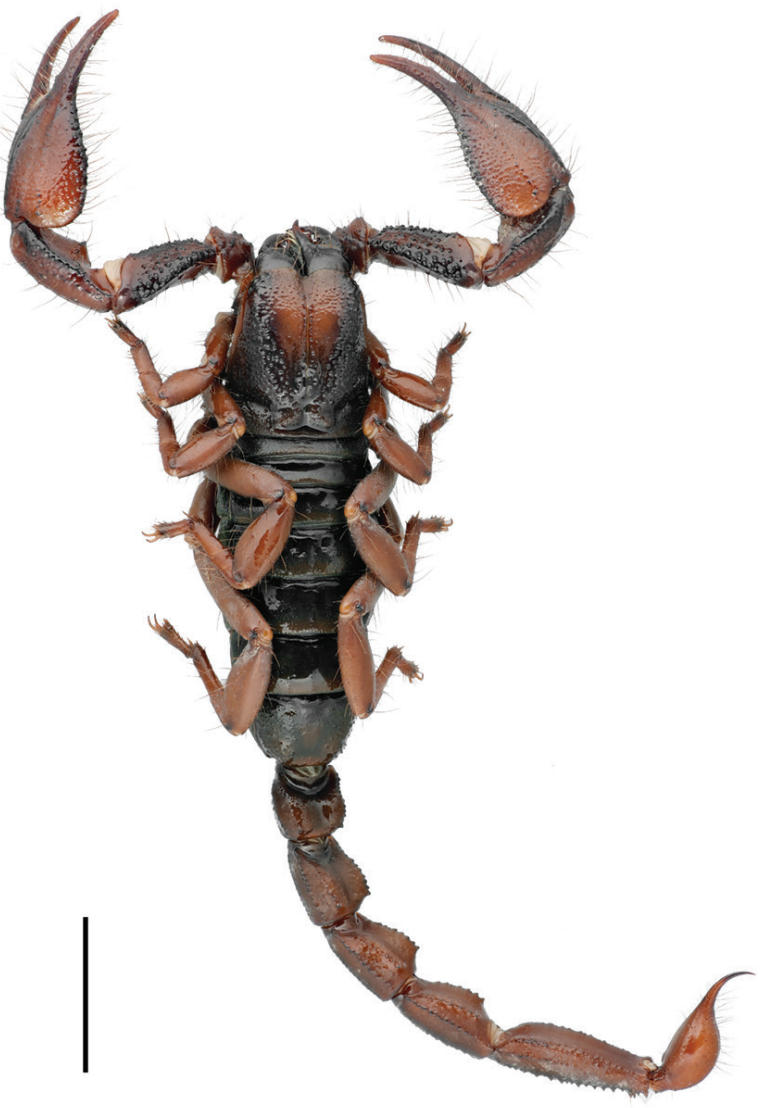

C

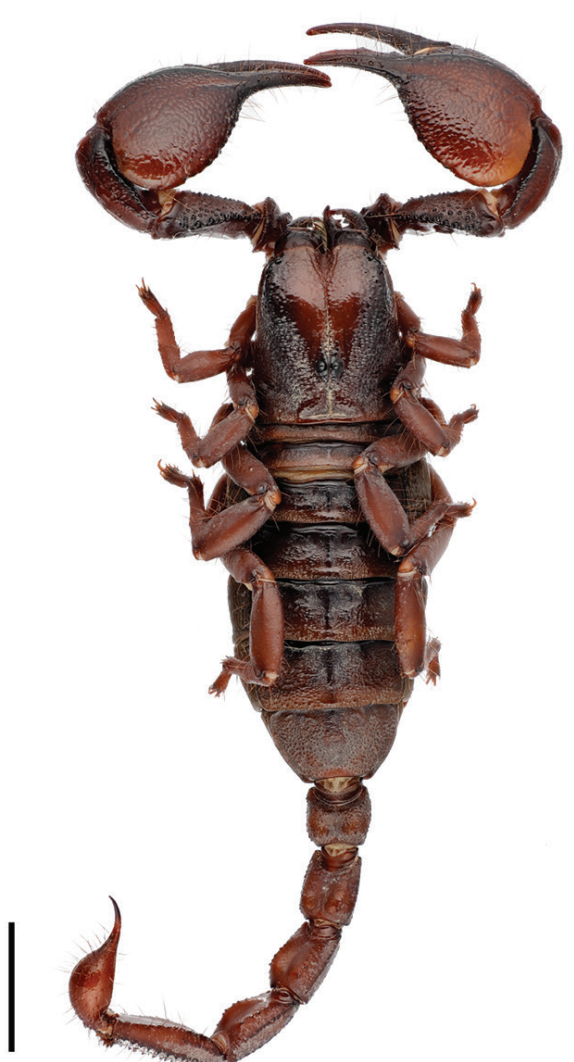

B

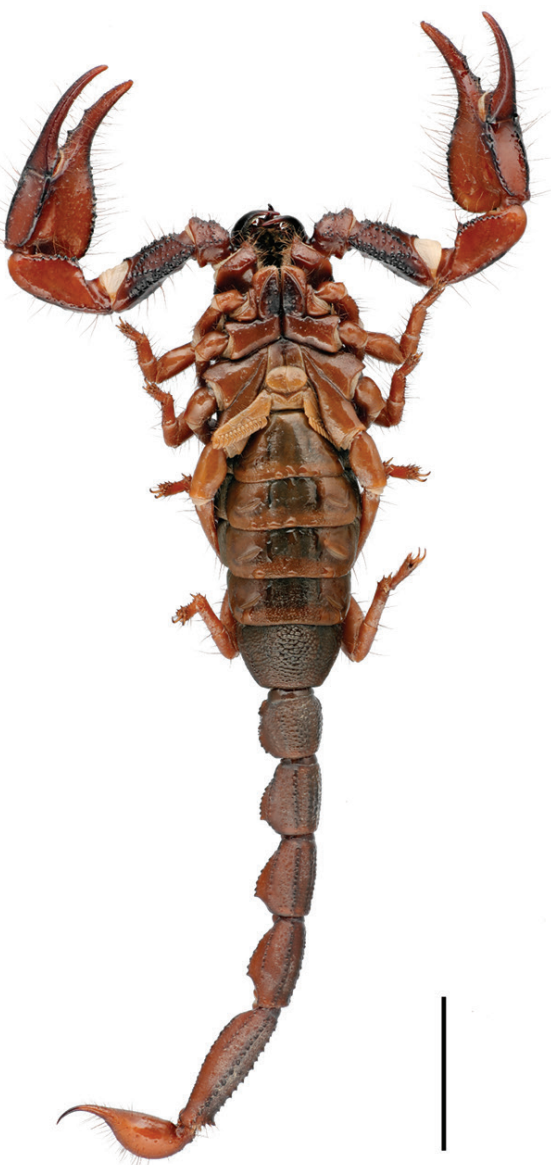

D

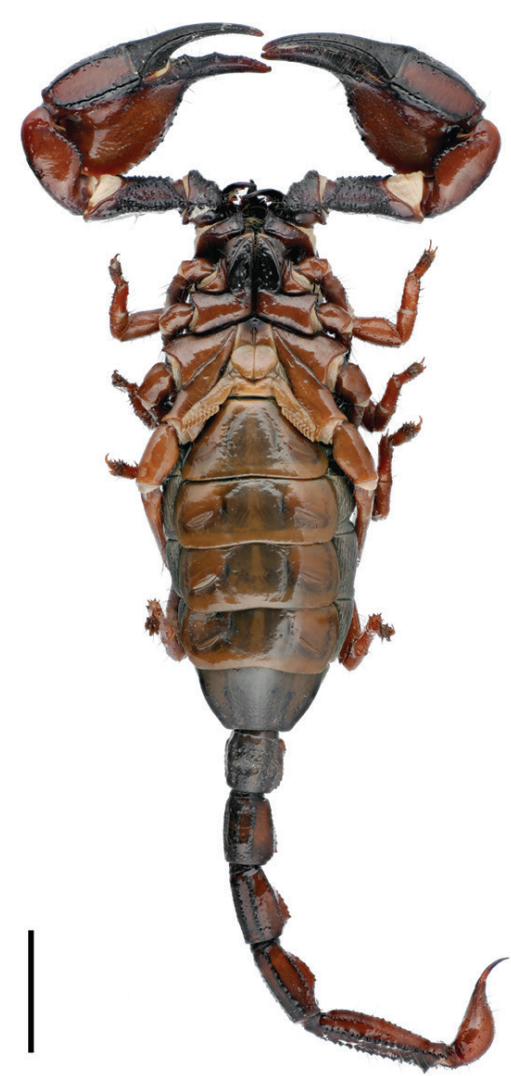

Figure 49. Opistophthalmus fuscipes Purcell, 1898, 1 male (A-B), female (C-D): A, C dorsal aspect of habitus B, D ventral aspect of habitus. Scale bars: $10 \mathrm{~mm}$. 
A

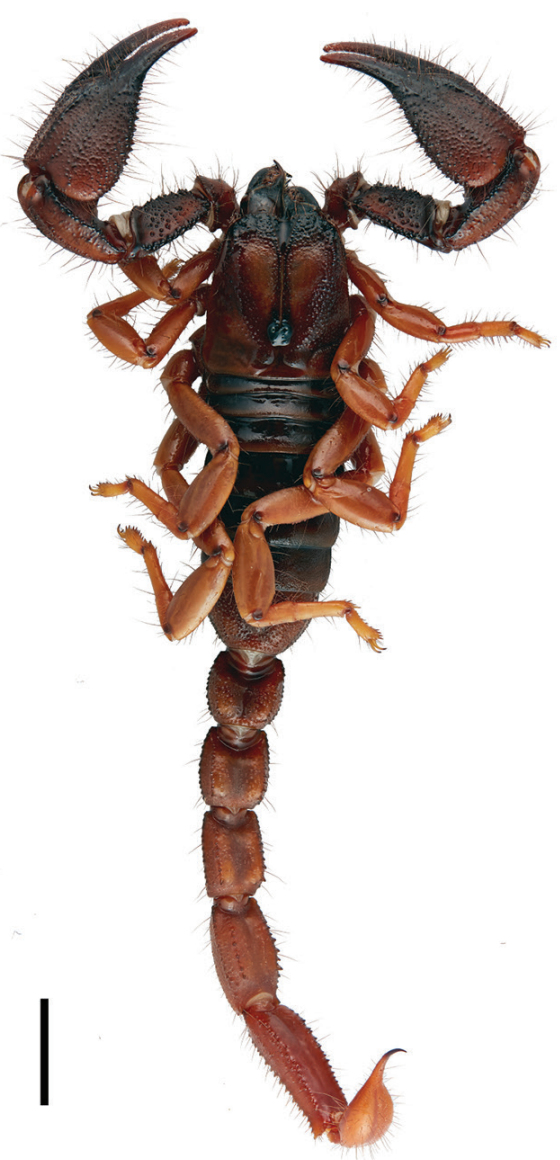

C

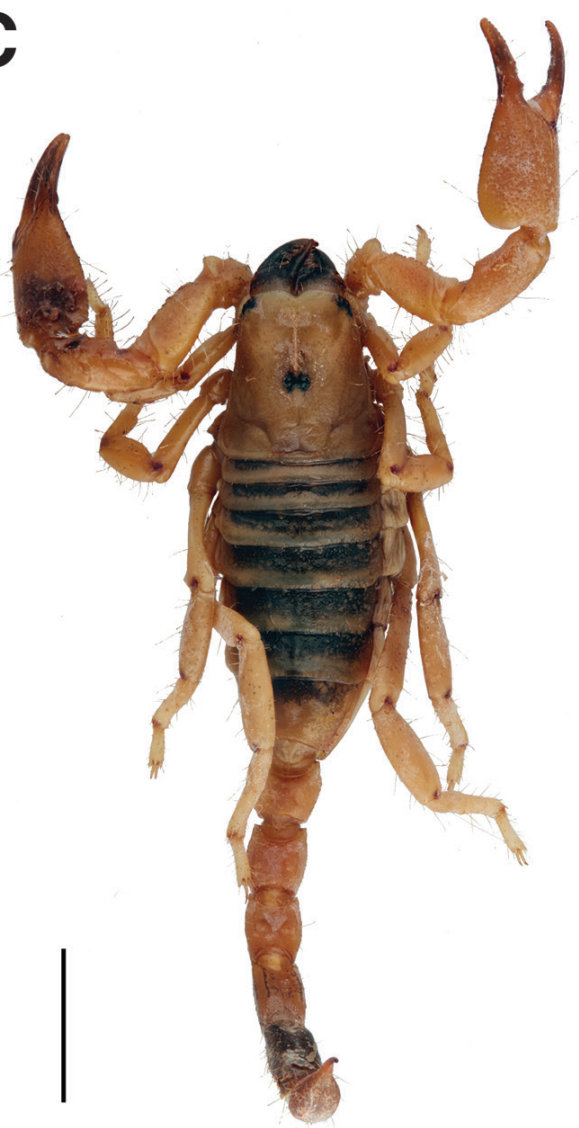

B

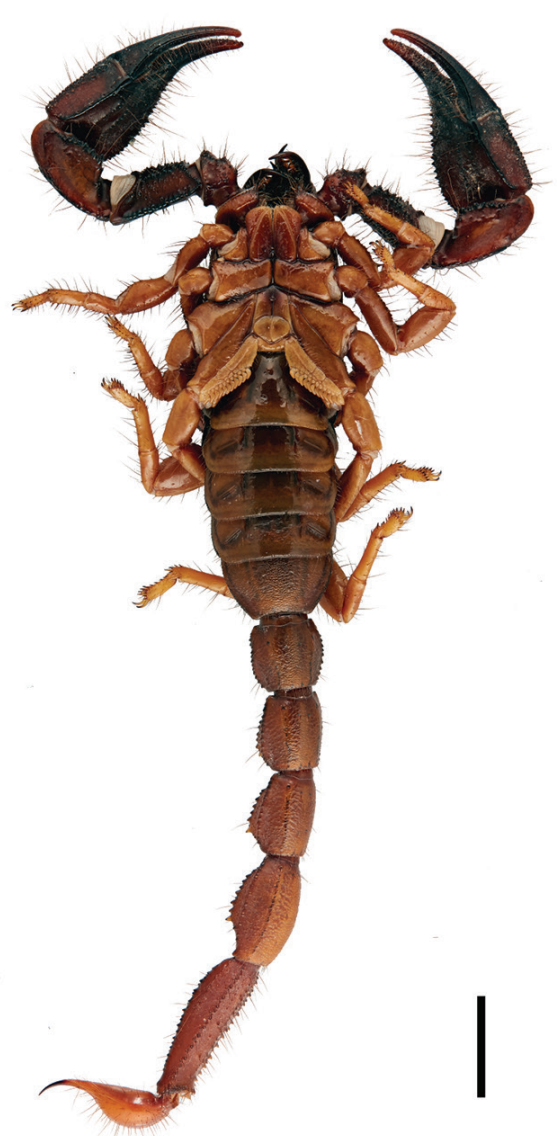

D

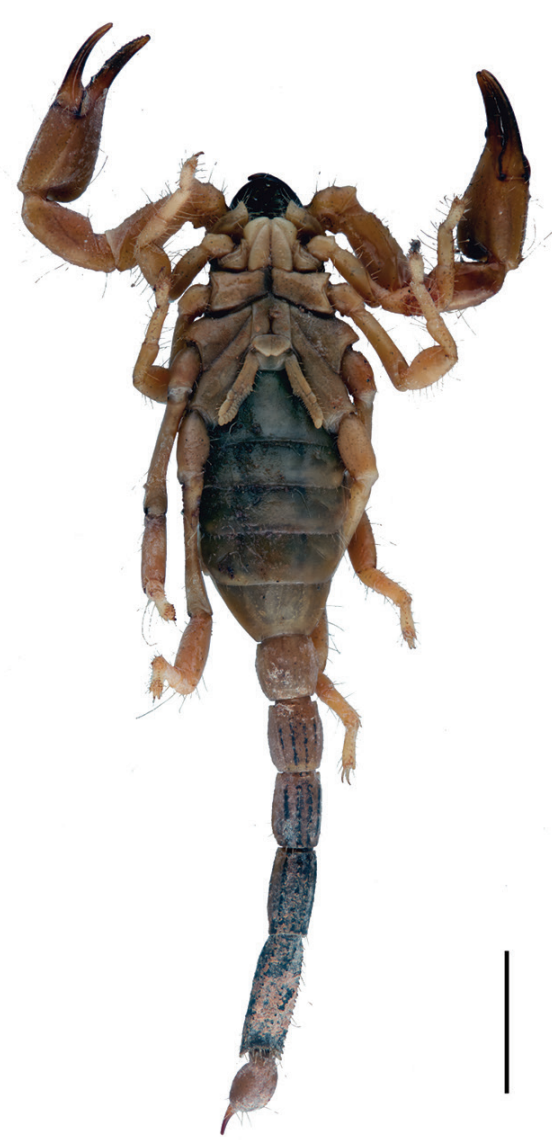

Figure 50. Opistophthalmus granicauda Purcell, 1898, male paralectotype (A-B). Opistophthalmus intercedens Kraepelin, 1908, juvenile paralectotype (C-D): A, C dorsal aspect of habitus B, D ventral aspect of habitus. Scale bars: $10 \mathrm{~mm}$. 


\section{Opisthophthalmus latimanus karrooensis}

Opisthophthalmus latimanus karrooensis Purcell, 1899: $1-5$

Current combination. Opistophthalmus karrooensis Purcell, 1899

Probably not types. 1 ô, 1 (ZMH-A0001866), [South Africa], Cap-Kolonie [Northern Cape], Little Bushmanland [29³4'12.8'S, 18³0'58.6”E], 27.11.1898, F. Purcell leg.

Remarks. The types could not be examined nor photographed as they were on loan at the time of writing. Fet (2000c) only listed specimens in the SAMC (62 syntypes) and none in the ZMH. Prendini (2001) designated lectotype and paralectotypes from a series of 129 specimens in the SAMC. The locality data mentioned by Fet (2000c) and Prendini (2001) do not correspond to the data of the present specimens which are thus probably not types. Prendini also confirms that he does not consider these specimens as type (pers. comm.).

\section{Opisthophthalmus latimanus keilandsi Fig. 51}

Opisthophthalmus latimanus keilandsi Hewitt, 1914: 7-8

Current combination. Opistophthalmus keilandsi Hewitt, 1914 [elevated to species status by Prendini, 2001: 27]

Probably not types. $1 \curvearrowright$ (Fig. 51A-B), 1 (Fig. 51CD) (ZMH-A0000911), [South Africa], Kapland, Eastern Cape Colony [Eastern Cape], Keilands [32 $11^{\prime} 00^{\prime} \mathrm{S}$, 27³0'00'E], Oestl. [to the East], 01.1913, J. Hewitt leg. (no 1728), ded. 06.1914.

Remarks. Hewitt (1914) listed one male and three females collected in "Keilands near Tsomo C.P., Rev. Fr. Albert Schweiger coll., Fr. P. Boneberg leg. (to the Albany Museum)". The locality of the ZMH specimens matches that of the types. According to the label, they were donated by Hewitt, the original author. However, four specimens (one female, three males) are present in the collections of the Albany Museum and have been designated as lectotype and paralectotypes by Prendini (2001: p.47). The ZMH specimens may have been gifted by Hewitt but do not appear to be types, contra Weidner (1959).

\section{Opisthophthalmus leipoldti \\ Fig. 52 \\ Opisthophthalmus leipoldti Purcell, 1898: 18-20, pl. III, fig. 5}

Current combination. Opistophthalmus leipoldti Purcell, 1898 [relegated as a subspecies of $O$. capensis by Hewitt 1918: 113, elevated to species status by Prendini 2001: 31]
Probably not types. $1 \lesssim$ (Fig. 52A-B), 1 (Fig. 52CD), 1 స, 1 , 1 subadult $q$ (ZMH-A0000916), [South Africa], Cap Colonie [Western Cape], Clanwilliam [3210'54’'S, 18 53'31'”E], 27.12.1895, C. L. Leipoldt leg., F. Purcell don.

Remarks. Purcell (1898) listed 21 specimens (4 males, 6 females, 11 juveniles) from Clanwilliam in the type series located in the South African Museum (Cape Town). The ZMH specimens are a gift to the Hamburg Museum but they are probably not part of the original series as explained by Prendini (2001). One lectotype male and 20 paralectotypes (three males, four females, one subadult male, four subadult females and eight juveniles) from the series of syntypes held at the SAMC were designated by Prendini (2001: 31). Given that the number of specimens at the SAMC matches the original data by Purcell, it is doubtfull that the five ZMH specimens are types (Prendini 2001: 47).

\section{Opisthophthalmus pictus \\ Fig. 53}

Opisthophthalmus pictus Kraepelin 1894: 80, 102-104, pl. I, fig. 35

Current combination. Opistophthalmus pictus Kraepelin, 1894

Paralectotypes. 4 (ZMH-A0000912), [South Africa], Oranje-Freistaat [Freestate], Reddersburg [29³9'10’S, 26¹0'03’'E], H. Meyer leg., ded. 30.04.1887.

Remarks. Kraepelin (1894) reported eight specimens in the type series: seven from Reddersburg in the $\mathrm{ZMH}$ collections and one from Cape Town in the Natural History Museum of Denmark, Kopenhagen (ZMUC). Prendini (2001) reported seven syntype specimens and designated one female lectotype (ZMB/Arach-7186) in the ZMB, four females paralectotypes in the $\mathrm{ZMH}$ (the specimens listed here), one female paralectotype in the BMNH, and one female paralectotype in the ZMUC.

Remarks on collector. The possible collector is Hans Meyer (1858-1929) who was a German geographer and the first European to reach the summit of Mount Kilimanjaro in 1889. Meyer traveled extensively in eastern Africa but we are not sure if he also traveled to southern Africa.

\section{Opisthophthalmus pilosus}

Opisthophthalmus pilosus Werner 1936: 187-188, fig. 5

Current senior synonym. Opistophthalmus flavescens Purcell, 1898 [synonymized by Prendini 2001: 24]

Syntypes (lost). Data according to the original description: 1 , Südwestafrika [German South West Afri$\mathrm{ca}=$ Namibia], [Karas Region], Lüderitzbucht [Lüderitz Bay] [26³8'58'S, 15¹0'03”E], 30-40 km im Umkreis Dünen [30-40 km within sand dunes], Eberlanz leg., en- 

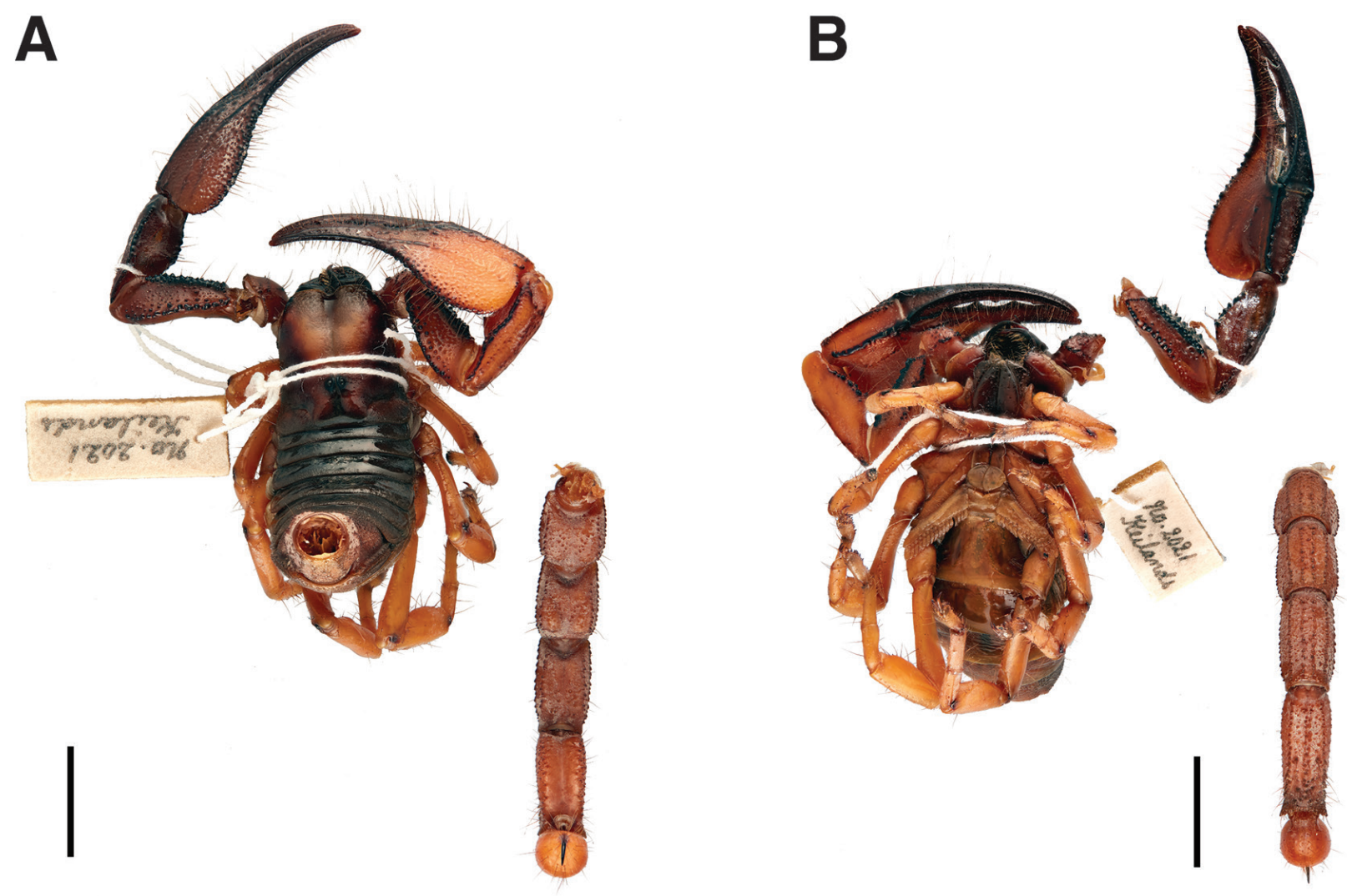

C

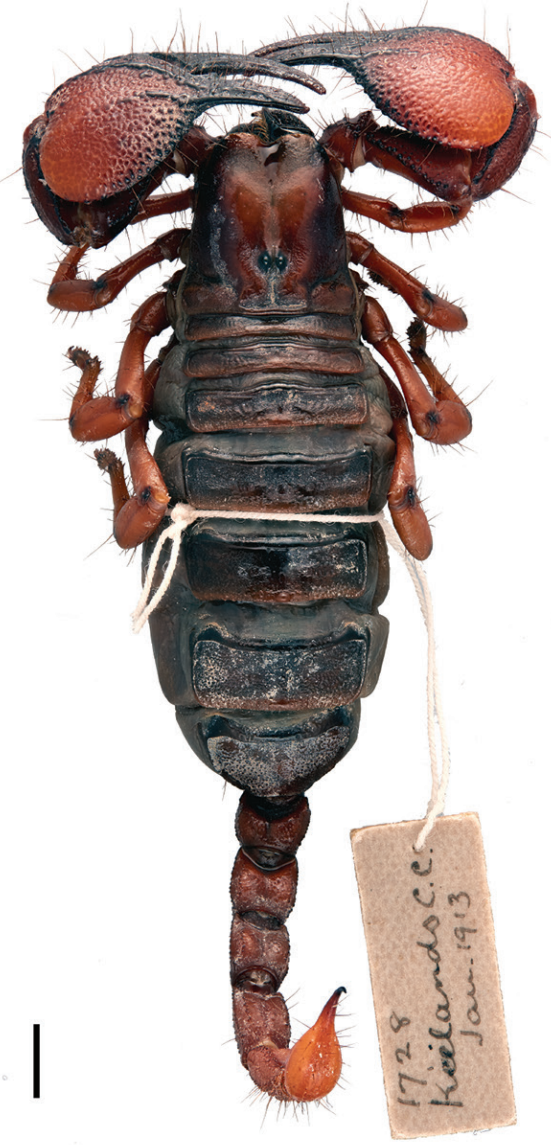

D

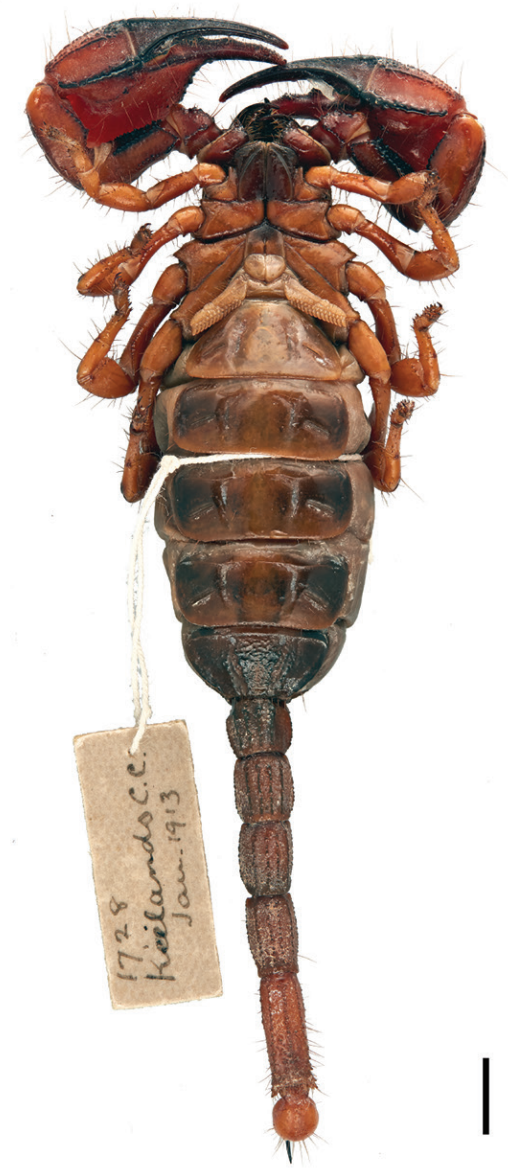

Figure 51. Opistophthalmus keilandsi Hewitt, 1914, male (A-B), female (C-D): A, C dorsal aspect of habitus B, D ventral aspect of habitus. Scale bars: $10 \mathrm{~mm}$. 

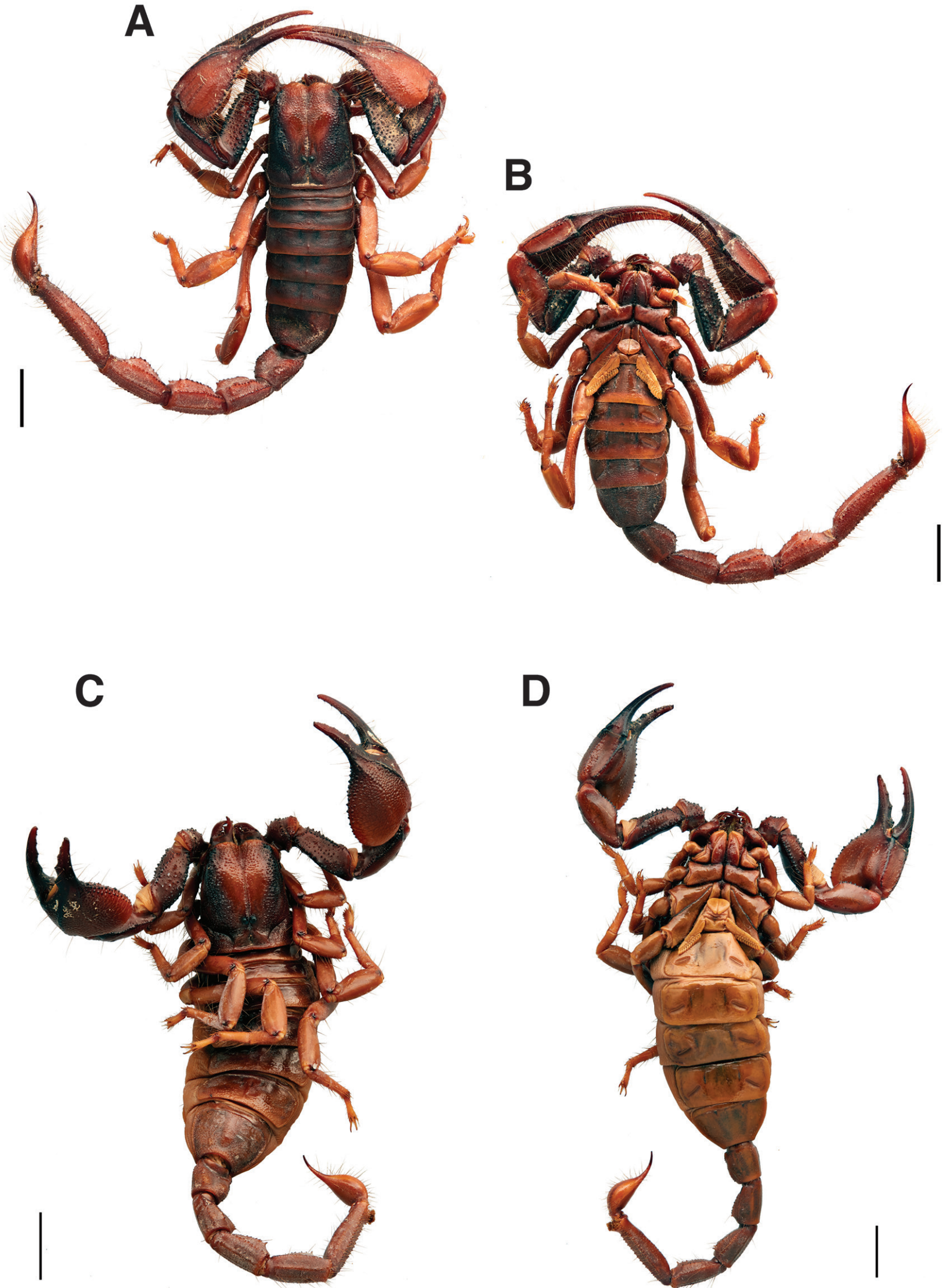

Figure 52. Opistophthalmus leipoldti Purcell, 1898, male (A-B), female (C-D): A, C dorsal aspect of habitus B, D ventral aspect of habitus. Scale bars: $10 \mathrm{~mm}$. 

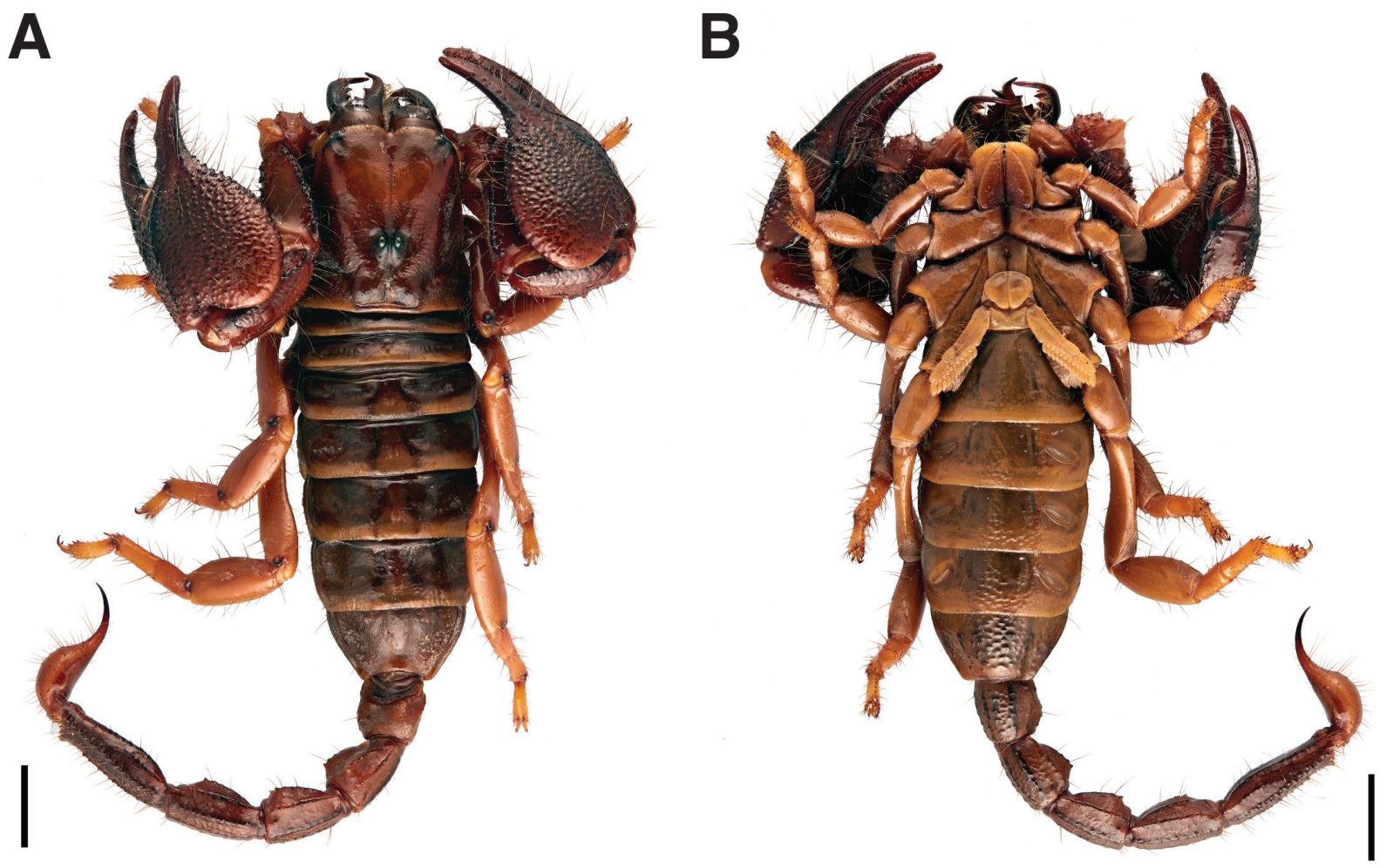

Figure 53. Opistophthalmus pictus Kraepelin 1894, female paralectotype, habitus A dorsal aspect B ventral aspect. Scale bars: $10 \mathrm{~mm}$.

try number 44 (1929); 1 , Deutsch-Südwestafrika [German South West Africa=Namibia], Prof. Dr. Griess leg., entry number 18 (1929).

Remarks. The syntype series was lost during a plane crash when the material loaned to B. H. Lamoral was sent back to Hamburg (label in jar from H. Dastych: "B. H. Lamoral 18.XI.1974; Das ganze Material ist verloren, 1975. Das Flugzeug ist abgestürzt”). Lamoral and Reynders (1975: 563) established Opisthophthalmus werneri as a replacement name for $O$. pilosus Werner, 1936 wich is a junior homonym of $O$. pilosus C. L. Koch, 1838. Prendini (2001: see p.24 for details) later demonstrated that $O$. werneri is a junior synonym of Opisthophthalmus flavescens Purcell, 1898.

\section{Opisthophthalmus schultzei \\ Fig. $54 \mathrm{~A}-\mathrm{B}$}

Opisthophthalmus schultzei Kraepelin, 1908d: 261-263

Current combination. Opistophthalmus schultzei Kraepelin, 1908

Paralectotypes. $1 q$ (Fig. $\quad$ 54A-B), 2 q (ZMH-A0000913), 2 subadult $\hat{\jmath}$ (ZMH-A0002216), [Namibia], Gross Namaland, [Karas Region], Kubub [2644'00'S, 16¹7'00'E], 06.1907, Leonhard Schultze leg., ZMB.

Remarks. Kraepelin (1908d ) mentioned numerous specimens (male, female and juveniles). The bulk of the original series is deposited in the $\mathrm{ZMB}$, and specimens were donated to the Albany Museum (Grahamstown, South Africa) and to the ZMH. Lectotype (1 female) and paralectotype (1 male) were designated by Lamoral (1979: 750) from the syntype series in the ZMB. Fet (2000c: 463) listed material in Berlin and Albany as well as 6 paralectotypes ( 2 males, 4 females) in Hamburg. Prendini (2001: 40) examined 25 specimens in the ZMB [one lectotype female, one subadult male paralectotype (ZMB14988); three subadult males paralectotypes (ZMB14989); 4 females, one subadult male, one subadult female, two juvenile females, eight first instars paralectotypes (ZMB14990); two females paralectotypes (ZMB14991); one subadult male paralectotype (ZMB14992); one female paralectotype (ZMB14996)] and two in the AMGS [one female and one subadult male paralectotypes]. There is a discrepancy between the number and sexes of specimens listed by Prendini (2001) and the online catalogue of the ZMB [19 specimens in total: one subadult female (ZMB/Arach-14988a lectotype); one male, one subadult female, one juvenile male (ZMB/ Arach-14988b-c, paralectotypes), three males (ZMB/ Arach-14989, paralectotypes); eight females and one juvenile (ZMB/Arach-14990, paralectotypes); two males (ZMB/Arach-14991, paralectotypes); one male (ZMB/Arach-14992, paralectotype)].

Remarks on collector. See paragraph about Opisthophthalmus intercedens Kraepelin, 1908 above. 

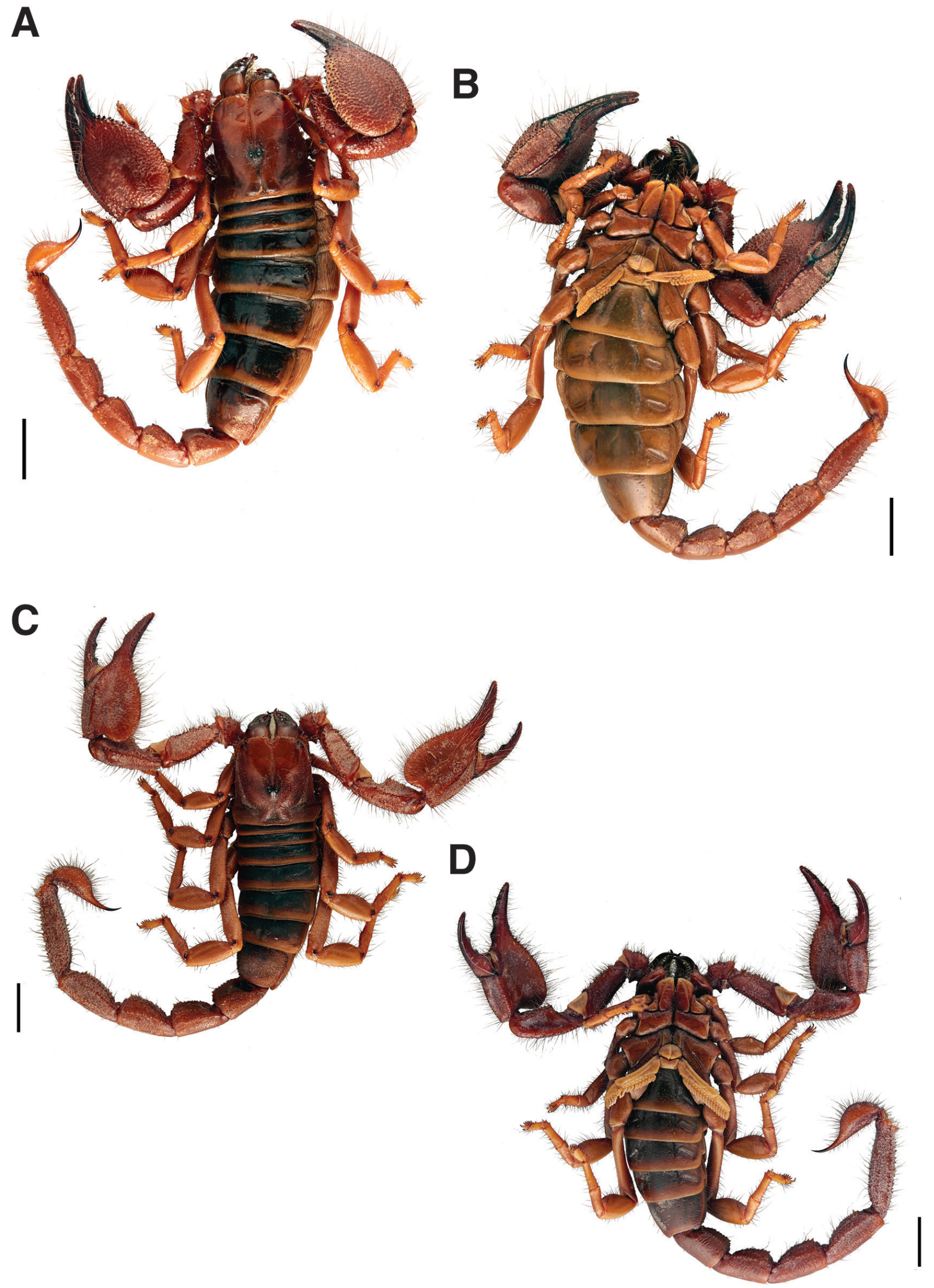

Figure 54. Opistophthalmus schultzei Kraepelin, 1908, female paralectotype (A-B). Opistophthalmus undulatus Kraepelin, 1908 [= Opistophthalmus schultzei Kraepelin, 1908], male syntype (C-D): A, C dorsal aspect of habitus B, D ventral aspect of habitus. Scale bars: $10 \mathrm{~mm}$. 


\section{Opisthophthalmus undulatus}

Fig. $54 \mathrm{C}-\mathrm{D}$

Opisthophthalmus undulatus Kraepelin, 1908d: 261, 263264

Current senior synonym. Opistophthalmus schultzei Kraepelin, 1908 [synonymized by Lamoral 1979: 745]

Syntypes. $1 \hat{\jmath}$ (Fig. 54C-D), $3 \hat{\jmath}$ (ZMH-A0001070), [Namibia], Gross Namaland, [Karas Region], Kubub [2644'00'S, 16¹7'00'E], 06.1907, Leonhard Schultze leg., ZMB.

Remarks. Kraepelin (1908d) mentioned numerous specimens (males, females and juveniles). However, while the bulk of the type series is deposited in the ZMB, four specimens of the type series were gifted to the $\mathrm{ZMH}$. According to Lamoral (1979), 2 syntypes should be deposited in the ZMB. Fet (2000c: 463) listed 21 syntypes in the Berlin collection and one in the AM (a gift from Berlin) but none in Hamburg. Prendini (2001: 40) examined 17 syntypes from the ZMB [14 males (ZMB14993), two males (ZMB14995), one male (ZMB 14997)] and one syntype male from the AMGS. He also (Prendini 2001: 48) mentioned in a footnote the existence of three additional specimens from the type series in the ZMB [two males (ZMB14994); one male (ZMB14996)] and four in the ZMH. Currently, the online catalogue of the ZMB reports 20 syntypes [2 males, 12 non-sexed specimens (ZMB/Arach-14993), 2 males (ZMB/Arach-14994), 2 males (ZMB/Arach-14995), 1 male (ZMB/Arach-14996), 1 male (ZMB/Arach-14997)].

Remarks on collector. See paragraph about Opisthophthalmus intercedens Kraepelin, 1908 above.

\section{Genus Pandinurus Fet, 1997}

\section{Scorpio gregorii}

Fig. 55A-B

Scorpio gregorii Pocock, 1896: 432-435, pl. XVIII, fig. 3, 3a

Current combination. Pandinurus gregoryi (Pocock, 1896)

Syntype. 1 ㅇ (ZMH-A0000941), [Kenya], [Taita Taveta], S. W. Tzavo [Tsavo] [259'52’'S, 38²7’30”E], [04-05.1893], John Walter Gregory leg., BMNH don., ded. 06.1897.

Remarks. Pocock (1896) listed a female from «Kinani», a female from «Tanganyko (confluence of the Athi River)», and six specimens (two males, three females and a juvenile) from Tzavo. The present specimen is part of the material collected in Tzavo and was donated by the BMNH, the other specimens remain in London.

Remarks on collector. John Walter Gregory (18641932) was a British geologist and explorer who studied glacial geology and geography and geology of Australia and East Africa. He led the first scientific expedition to Mount Kenya in 1902-3 (Gregory 1896). The crew reached the foothills of the mountain from the coast to Lake Baringo in the Rift Valley, and managed to ascend as far as the glaciers area at around $4730 \mathrm{~m}$. When traveling from Mombasa to Machakos, Gregory stopped at Tzavo station sometime between April and May 1893. There he collected most of the type material (Gregory 1896: 74): "In company with the Goanese commandant I spent a pleasant afternoon catching lizard and scorpions, and digging up the skulls of some Wa-kamba who had been killed by the Masai".

\section{Scorpio pallidus}

Fig. 55C-D

Scorpio pallidus Kraepelin, 1894: 33, 60-62, pl. I, fig. 11

Current combination. Pandinurus pallidus (Kraepelin, 1894)

Lectotype. 1 subadult $\widehat{\jmath}$ (ZMH-A0001872), [Indonesia], Baravez, Sumatra, 02.03.1891, Putre leg. Corrected after Pocock (1896) to "Somalia, [Lower Shabeelle], Barawa [1 ${ }^{\circ} 06 ’ 30$ 'N, 4350'41'"E]"' (see below).

Paralectotypes. 2 juveniles (ZMH-A0000938), same data as lectotype.

Remarks. Kraepelin (1894) mentioned four specimens in the type series. According to Pocock (1896: 435), the handwritten labels were incorrectly deciphered by Kraepelin and should be interpreted as "Barawa, Somalia" instead of "Baravez, Sumatra". Upon examination of the labels, we agree with Pocock conclusion. Moreover, the genus Pandinurus is exclusively African, and Sumatra is completely out of its distribution area. The ZMH series comprises three animals and the additional specimen may be lost or may have been donated to another museum. The subadult male is designated as the lectotype, the other two specimens as paralectotypes.

Remarks on collector. Two potential collectors were identified here for these specimens: Johann Maria Hildebrandt (1847-1881) and Gustav Adolf Fischer (18481886). Hildebrandt was a German explorer and scientist. From 1871 to 1881 he made several expeditions to the Horn of Africa and the Great Lakes during which he amassed important collections of botanical and zoological specimens (Beentje 1998). A new species of skink, Trachypelpis hildebrandtii (Peters, 1874), was named after him based on material he collected in Barawa, Somalia (Peters 1874). A large part of his zoological collection is deposited in the ZMB. Fischer (See paragraph about Opisthacanthus (Nepabellus) fischeri Kraepelin, 1911 above for biographical details) also prospected in Barawa (1882-1883) and enlisted the services of local people to collect for him (Fischer, 1885c). At least a second scorpion species named after him, Uroplectes fischeri (Karsch, 1879), was described from the material that were collected back then. Fischer's zoological material is at least in part housed in the collections of the $\mathrm{ZMH}$ and it is thus more probable that the types of P. pallidus were collected by Fischer rather than Hildebrandt. 


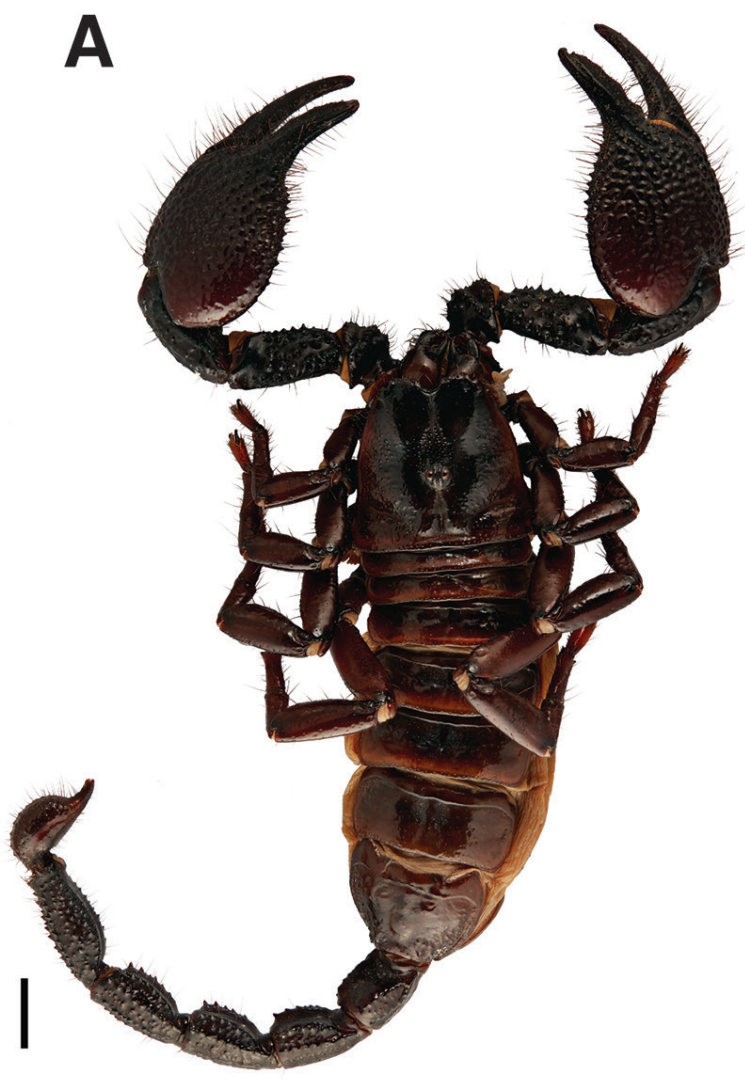

B
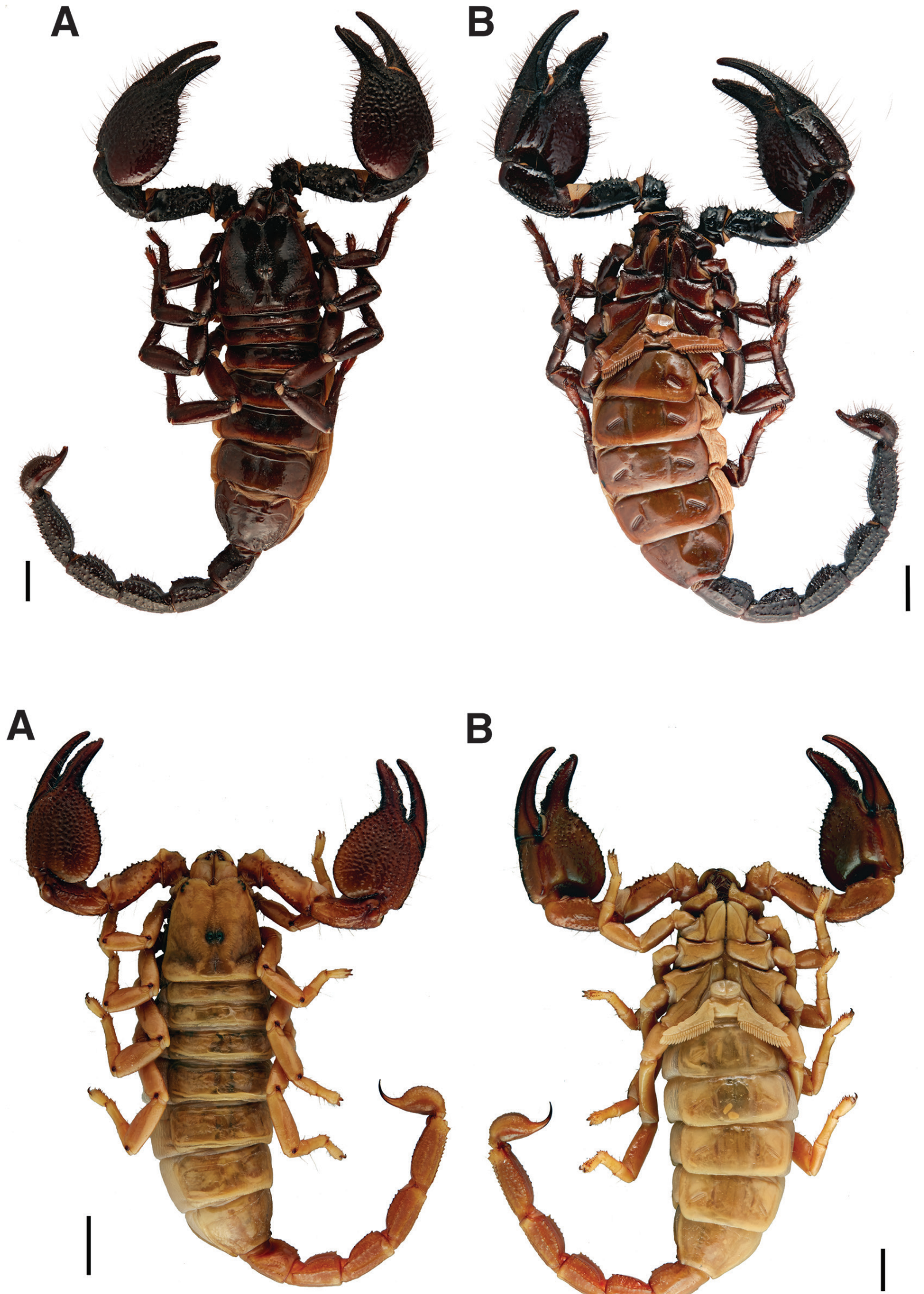

B

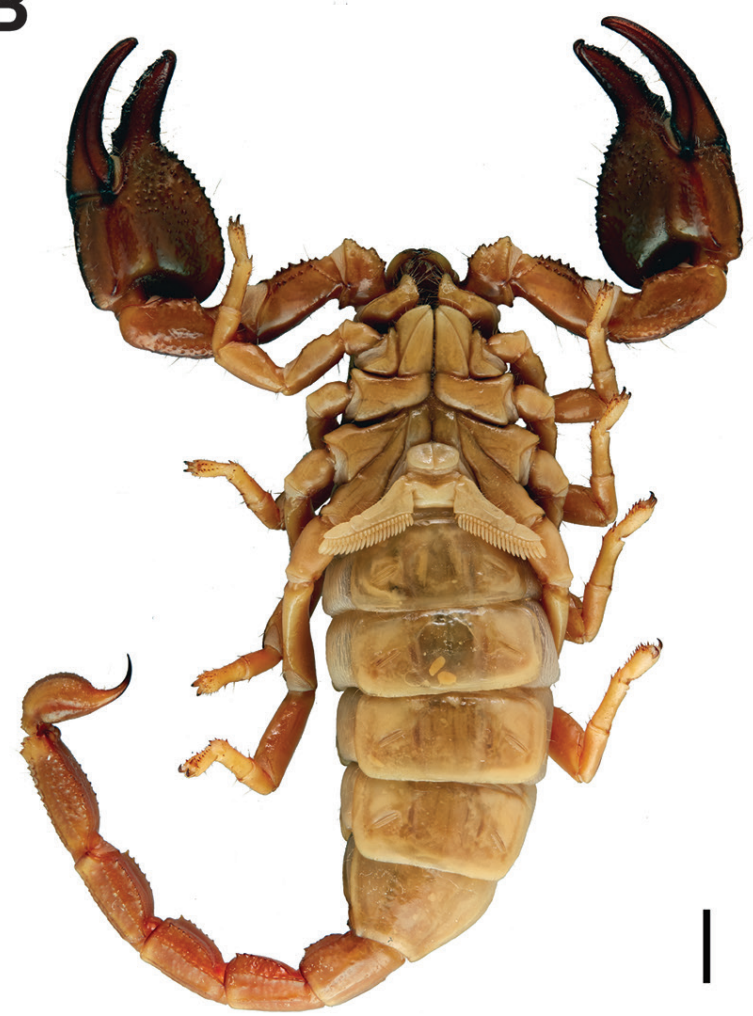

Figure 55. Scorpio gregoryi Pocock, 1896 [= Pandinurus gregoryi (Pocock, 1896)], female syntype (A-B). Scorpio pallidus Kraepelin, 1894 [= Pandinurus pallidus (Kraepelin, 1894)], 1 subadult male syntype (C-D): A, C dorsal aspect of habitus B, D ventral aspect of habitus. Scale bars: $10 \mathrm{~mm}$. 


\section{Genus Pandinus Thorell, 1876}

\section{Pandinus camerounensis}

Fig. 56

Pandinus camerounensis Lourenço, 2014b: 143-149

Current senior synonym. Pandinus imperator (C. L. Koch, 1841) [synonymized by Prendini 2016: 53]

Holotype. (Fig. 56) ڤึ (Fig. 56A-B, ZMH-A0001082), Cameroon, Regions of Sanguéré-Djoi/Kismatari/Djalingo (average coordinates: $\left.9^{\circ} 23.229^{\prime} \mathrm{N}, 13^{\circ} 50.068^{\prime} \mathrm{E}\right), 08.2011-$ 11.2012, cotton and tomato fields (in termite mounds), $\mathrm{P}$. Prudent leg. PS-0165-G1 (ZMH Eing. Nr. A19/14).

Paratypes. 1 subadult $\hat{O}, 2$ juveniles, same as holotype (ZMH Eing, Nr. A20/14).

Remarks. Two paratypes are deposited in the MNHN (Lourenço 2014b).

\section{Genus Scorpio Linnaeus, 1758}

\section{Scorpio maurus yemenensis}

Fig. 57

Scorpio maurus yemenensis Werner, 1936: 183-184, fig 4

Current combination. Scorpio yemenensis Werner, 1936 [raised to species-level by Lourenço and Cloudsey-Thompson 2009: 125]

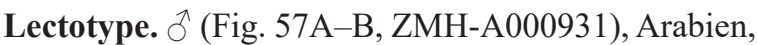
Yemen, Sanaa [15²1'17'N, 4412'24'E], 26.08.1931, Carl Rathjens leg. (ZMH Eing. Nr. 38.1932).

Paralectotypes. $9 \hat{\partial}, 17 \stackrel{+}{9} 9$ subadult $\hat{\partial}, 5$ subadult , 13 juveniles (ZMH-A0002213); 1 (Fig. 57C-D, ZMH-A000932), same data as lectotype.

Remarks. Werner (1936) provided the locality name and date as "Arabien, Yemen, Huka, Hazz, 1-7.1928, Eing. No. 36, 1928”. Weidner (1959) stated the same locality and a total of 55 specimens (one holotype and 54 paratypes). Although the number of specimens matches that of the series examined, the locality is different from that stated on the label in the jar. However, Huka/Haz are two villages in the Sanaa governorate, so it is possible that Werner have more detailed information on Rathjens travel itinerary. According to the ICZN, a lectotype male is designated here and the remaining specimens as paralectotypes.

Remarks on collector. Carl August Rathjens (18871966) was a German geographer with a special interest in South Arabian historiography, geology and ethnography. He travelled to Yemen in 1927, 1931, 1934 and 1938 (Anonymous 1970).

\section{Scorpio maurus occidentalis}

Fig. 58

Scorpio maurus occidentalis Werner, 1936: 184-185, fig. 4
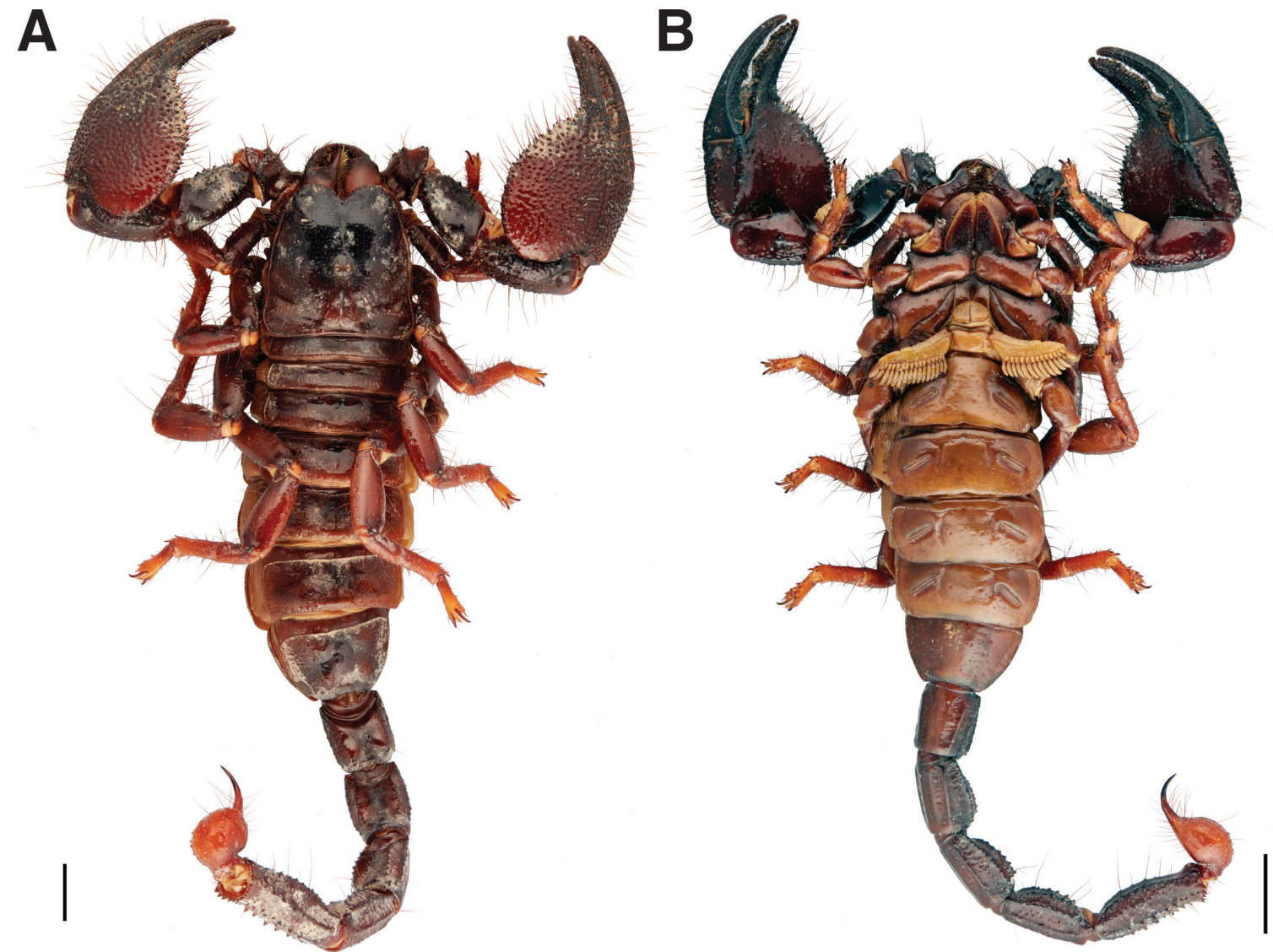

Figure 56. Pandinus camerounensis Lourenço, 2014, male holotype, habitus A dorsal aspect B ventral aspect. Scale bars: $10 \mathrm{~mm}$. 


\section{A}

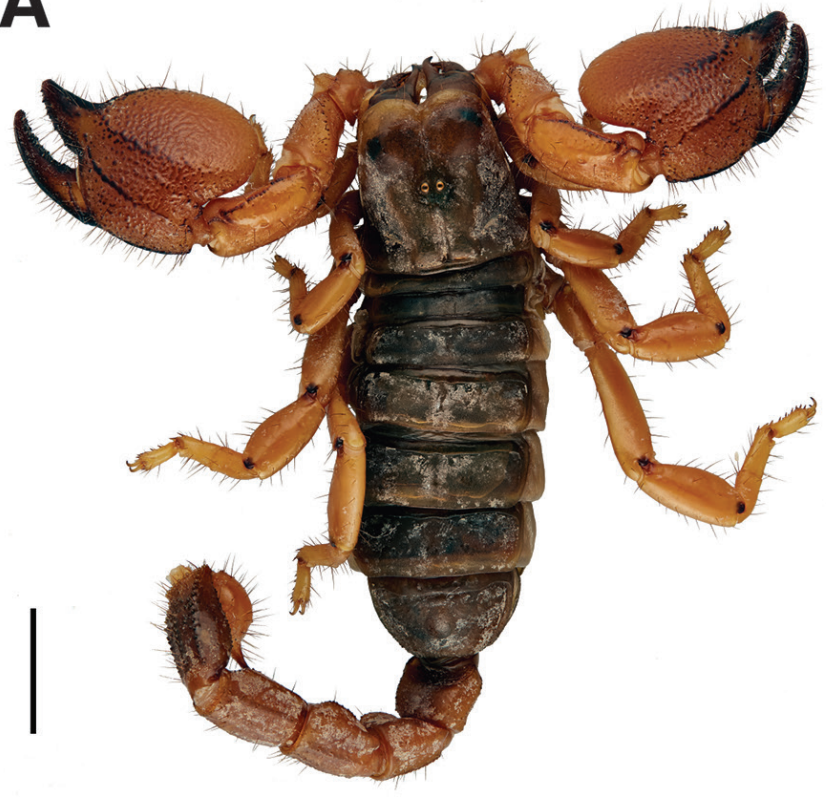

B

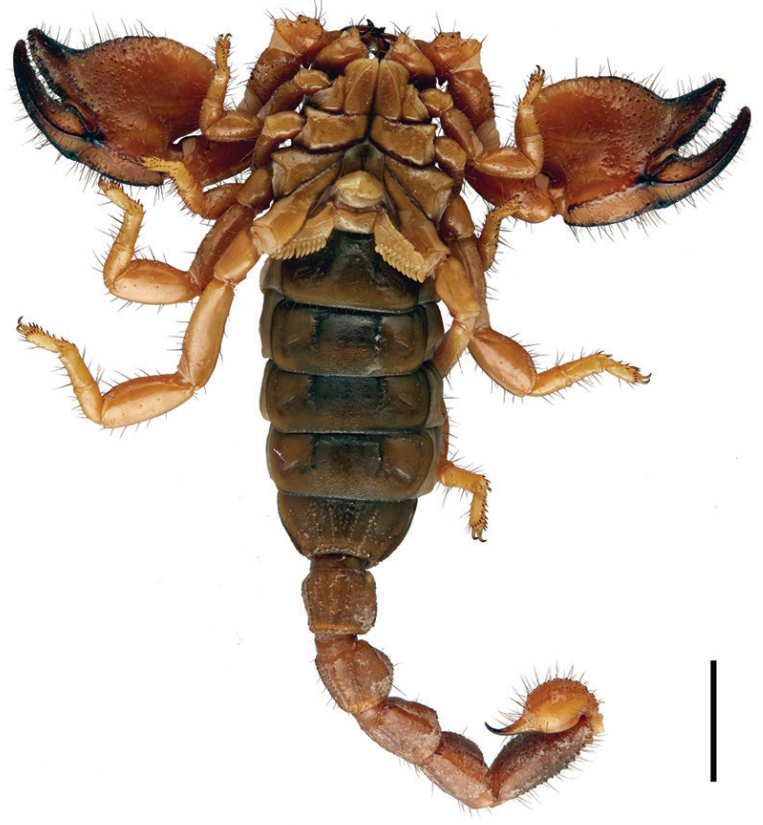

C

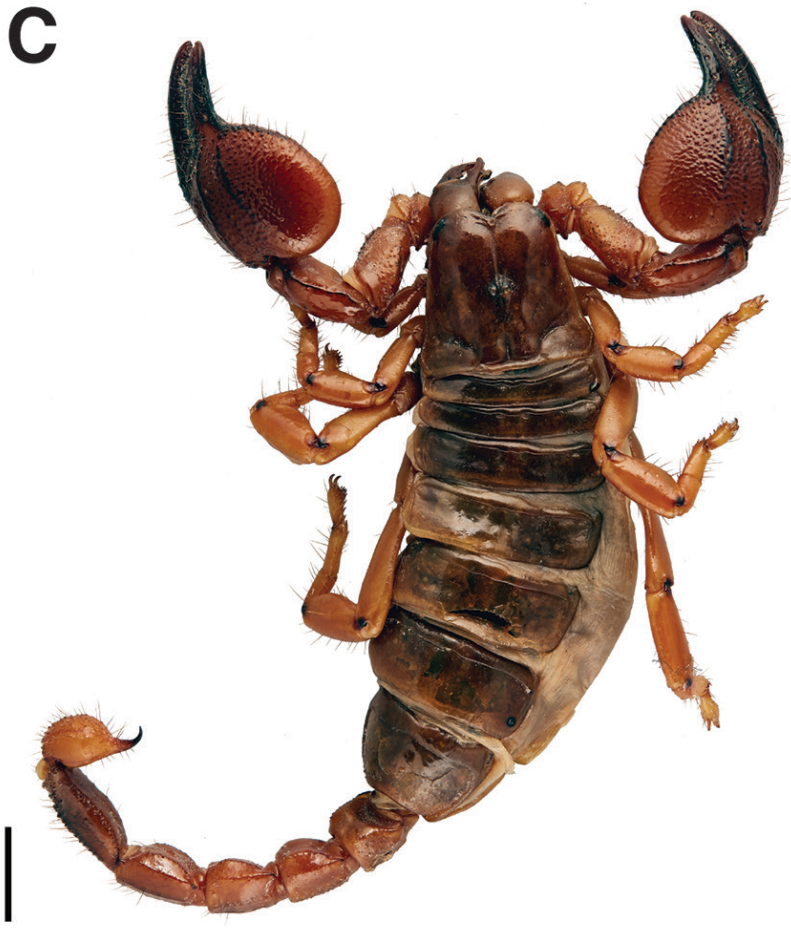

D

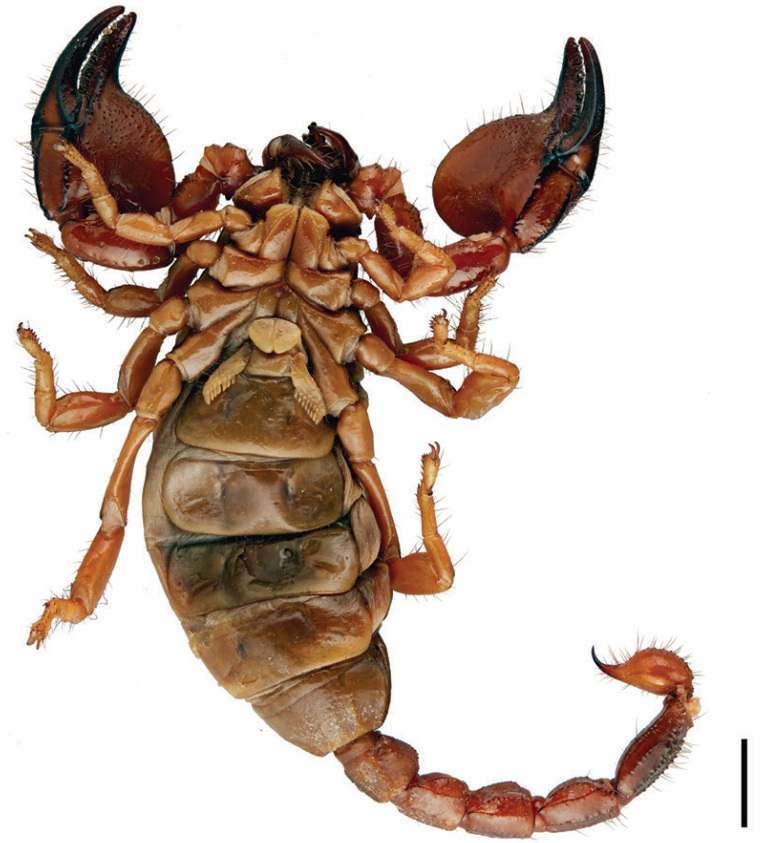

Figure 57. Scorpio yemensis Werner, 1936, male lectotype (A-B), female paralectotype (C-D): A, C dorsal aspect of habitus B, D ventral aspect of habitus. Scale bars: $10 \mathrm{~mm}$. 
A

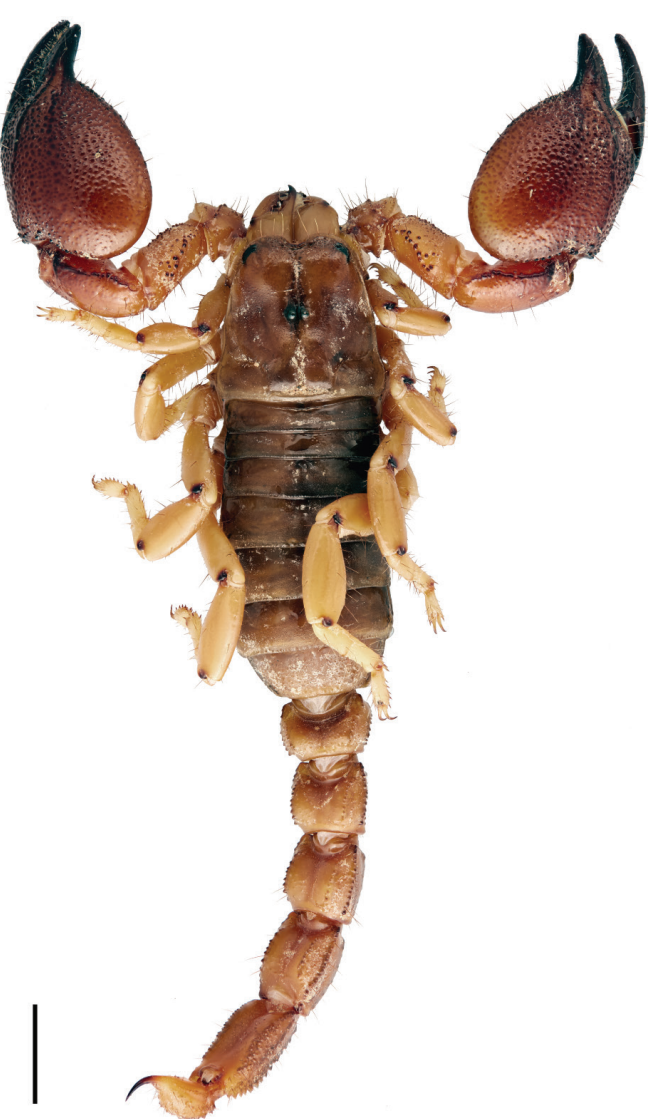

B

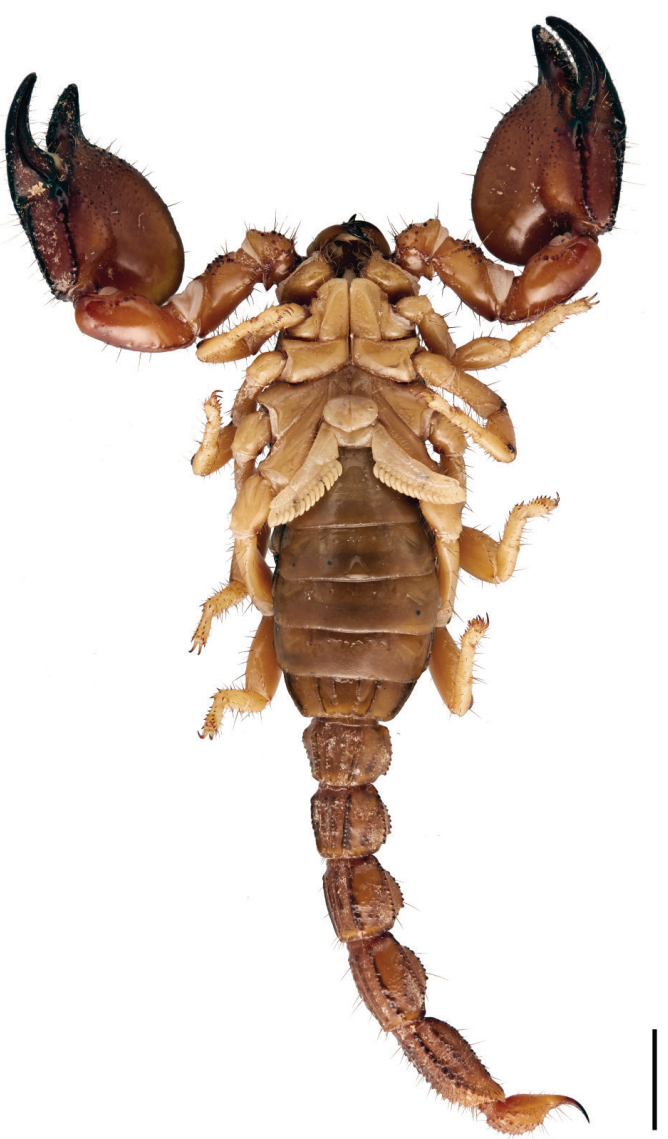

Figure 58. Scorpio occidentalis Werner, 1936, male neotype, habitus A dorsal aspect B ventral aspect. Scale bars: $10 \mathrm{~mm}$.

Current combination. Scorpio occidentalis Werner, 1936 [elevated to species rank by Lourenço 2009: 103]

Neotype. $\widehat{o}$ (ZMH-A0000895), Senegal, [Kédougou], Parc National du Niokolo-Kola [Niokolo-Koba National Park] [1300’27'N, 1254'52'W], 11.1979, P. M. Brignoli leg. (ZMH Eing. Nr. A8/09).

Remarks. Werner (1936) described the species from "Senegal, Wüstengebiet nördlich des Oberen Gambia" and Weidner (1959) listed the male holotype as lost ("verbrannt"). The original type was destroyed in 1943 according to Fet (2000c). Lourenço (2009) elevated the subspecies occidentalis to species level and designated a neotype.

\section{Scorpio savanicola}

Fig. 59

Scorpio savanicola Lourenço, 2009: 110-111

Current combination. Scorpio savanicola Lourenço, 2009

Holotype. (Fig. 59A-B) 1 ๙ (ZMH-A0000942), Cameroon, [North Region], South of Garoua [918'05'N, $\left.13^{\circ} 23^{\prime} 51^{\prime \prime} \mathrm{E}\right]$, savannah formation, 10.1981, P. M. Brignoli leg. (ZMH Eing. Nr. A10/09).
Paratypes. 1 (Fig. 59C-D), 1 subadult $q$ (ZMH-A0000897), same data as holotype (ZMH Eing. Nr. A9/09).

\section{Family Scorpiopidae Kraepelin, 1905}

Type specimens belonging to five species are present at ZMH.

\section{Genus Scorpiops Peters, 1861}

\section{Scorpiops afghanus}

Fig. $60 \mathrm{~A}-\mathrm{C}$

Scorpiops afghanus Lourenço \& Qi, 2006: 278, 280-284, figs. $2-15$

Current combination. Scorpiops afghanus Lourenço \& Qi, 2006

Holotype. (Fig. 60A-B) $q$ (ZMH-A0002212), Afghanistan, [Badakhshan Province], [Wākhān District], Valley

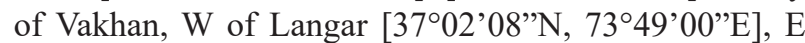
of Panjeh [Qal'ah-ye Panjah] [3700’02”N, 72³4'50”E], 3400m, 4.VI.1971, C. Naumann and E. Kullmann leg.

Paratypes. 2 juveniles (ZMH-A0002211), same data as holotype 
A

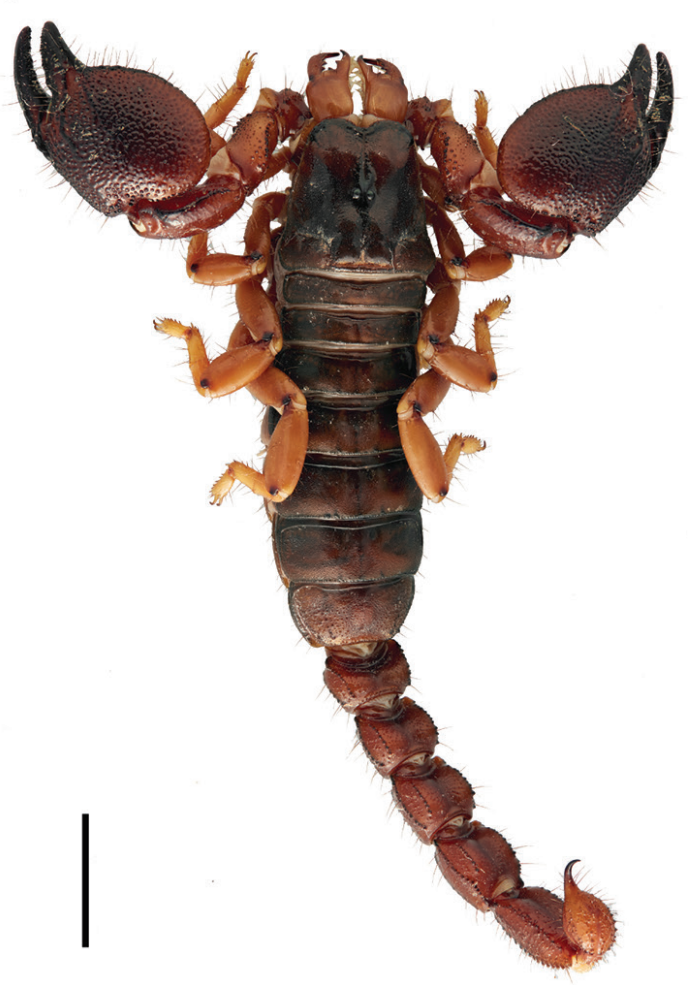

C

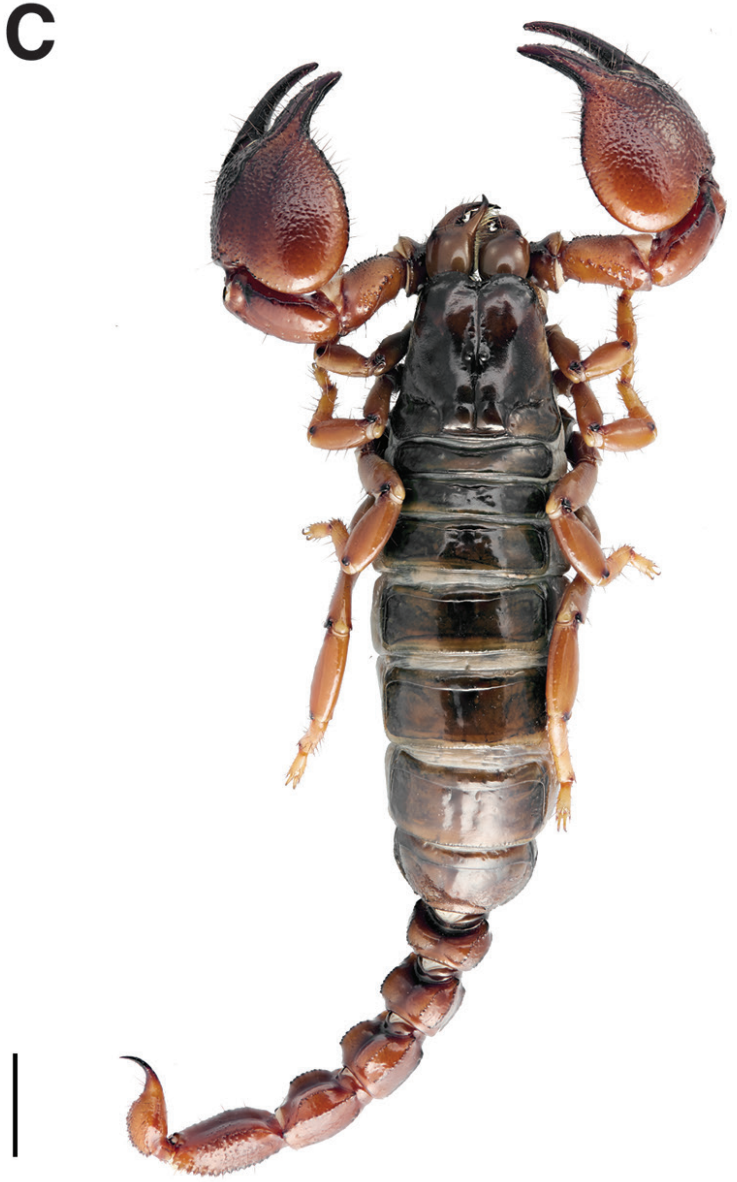

B

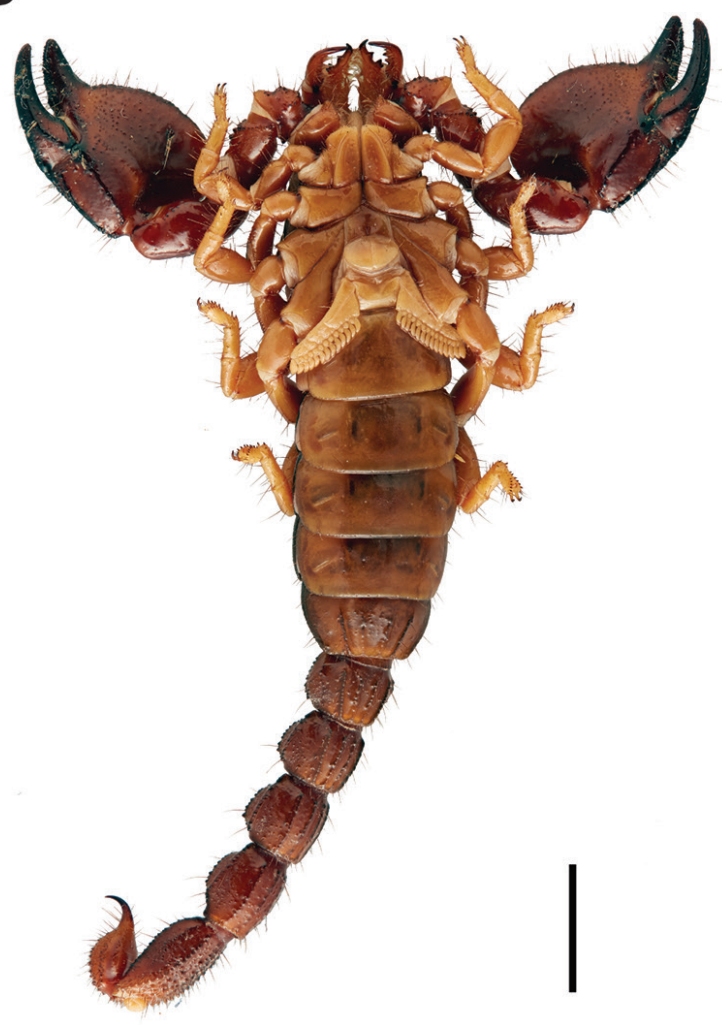

D

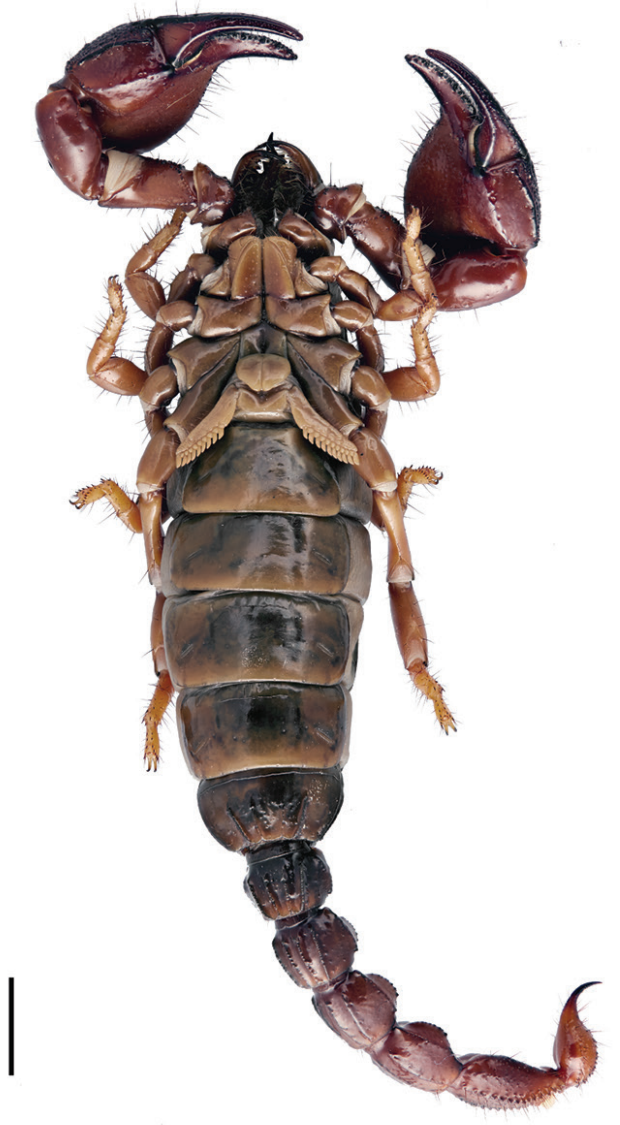

Figure 59. Scorpio savanicola Lourenço, 2009, male holotype (A-B), female paratype (C-D): A, C dorsal aspect of habitus B, D ventral aspect of habitus. Scale bars: $10 \mathrm{~mm}$. 
Remarks on collector. Clas Michael Naumann zu Königsbruck (1939-2004) was a Professor of Zoology at the University of Bonn and director of the Museum Alexander König in Bonn. His main interest was the biogeography of Afghanistan where he traveled extensively. Ernst Kullmann (1931-1996) was a German arachnologist and director of the Cologne Zoological Garden. The travel route of the "deutschen zoologish-botanischen Expedition 1971", in which Naumann and Kullman took part, is presented in the map of Naumann and Niethammer (1973: map p. 239).

\section{Scorpiops affinis}

Fig. 60D-F

\section{Scorpiops affinis Krapelin, 1898a: 44}

Current senior synonym. Scorpiops hardwickii (Gervais, 1843) [synonymized by Kovařík 2000: 174]

Lectotype. đ̊ (ZMH-A0001203), Himalaya, Henri de Saussure (MHNG) don., ded. 06.1896.

Remarks. The specimen in the ZMH was designated as the lectotype by Kovařík (2000: 176). Kraepelin (1898a) apparently examined more than one specimen because he reported a number of pectinal teeth between five and seven, whereas the present male has six teeth on each pectine. In the absence of the other syntypes, we agree with Kovařík's assessment.

Remarks on collector. Adolphe (1829-1857), Hermann (1826-1882) and Robert Schlagintweit (18331885) were German explorers who regularly sent zoological specimens collected during their travels to Henri de Saussure (1829-1905). In 1854, the brotherhood was commissioned by the East India Company to organize a scientific expedition in their territory. For the next three years, they explored the Deccan, and then the Himalayas, Karakoram and Kuen-lun Mountains (Schalgintweit, Schlagintweit and Schlagintweit 1861). The present specimen was probably collected during this expedition.

\section{Scorpiops dastychi}

Fig. 61

Scorpiops dastychi Kovařík, 2000: 170-172, 197, fig. 29, $33-34,45,50-51$, tab. 1-3

Current combination. Scorpiops dastychi Kovařík, 1999

Holotype. (Fig. 61A-C) đ̊ (ZMH-A0001062), India, [Uttarakhand], Himalaya, Molta $\left[30^{\circ} 28^{\prime} 52^{\prime} \mathrm{N}\right.$, 79³2'23”E], 3000m, 06.05.1956 (ZMH 11, batch no. 386), Deutsche Indien-Expedition 1955-57, G. A. von Maydell leg. (ZMH Eing. Nr 1, 1956).

Paratypes. $q$ (Fig. 61D-F, ZMH-A0001063), same data as holotype; India, [Uttarakhand], Himalaya, Molta [30'28'52'N, 79³2'23'E], 3000m, Deutsche Indien Expedition 1955-57, G. A. von Maydell leg. (ZMH
Eing. Nr 1, 1956); 16.05.1956 (batch no. 402-403), Kovařík Paratypes No. 11-16, 6 ภे (ZMH-A0002192); 17.05.1956 (batch no. 405), Kovařík Paratypes No. 1718, 2 § (ZMH-A0002196); 26.05.1956 (batch no. 416), Kovařík Paratypes No. 19-23, 5 ठิ (ZMH-A0002198); 11.V.1956 (batch no. 430), Kovař́k Paratypes No. 24 25, 2 o (ZMH-A0002197); 09.05.1956 (ZMH 20, batch no. 389), Kovařík Paratypes no. 32-35, 1 subadult + , 2 juveniles (ZMH-A0002203); 16.05.1956 (ZMH 1213, batch no. 402-403), Kovařík Paratypes no. 38-47, 1 ô, 4 subadult $\hat{O}, 5$ subadult $q$ (ZMH-A0002202); 9.V.1956 (ZMH 18, batch no. 405), Kovarik Paratypes no. 48-59, 12 ㅇ (ZMH-A0002210); 26.05.1956 (ZMH 14, batch no. 416), Kovařík Paratypes no. 60-62, 3 subadult + (ZMH-A0002201); 11.06.1956, (ZMH 19, batch no. 430), Kovařík Paratypes No. 63-67, 2 subadult $\bigcirc, 2$ subadult ${ }^{\lambda}, 1$ juvenile (ZMH-A0002194); 13.06.1956 (ZMH 17, batch no. 432), Kovařík Paratypes No. 68, 1 (ZMH-A0002199);19.06.1956 (ZMH 11, batch no. 449), Kovařík Paratypes no. 69-72, 1 స, 1 , 2 juveniles (ZMH-A0002193); 6.06.1956 (ZMH 11, batch no. 386), Kovařík Paratypes no. 74-76, 3 juveniles (ZMH-A0002195); 09.05.1956 (ZMH 20, batch no. 388), Kovařík Paratypes no. 77-79, 3 juveniles (ZMH-A0002209); 16.05.1956 (ZMH 12-13, batch no. 402-3), Kovařík Paratypes no. 80-83, 1 subadult đ̃, 3 juveniles (ZMH-A0002204); 11.06.1956 (ZMH 19, batch no. 430), Kovařík Paratypes no. 84-86, 3 juveniles (ZMH-A0002206); 19.06.1956 (ZMH 05, batch no.449), Kovařík Paratypes no. 87, 1 juvenile (ZMH-A0002207); 19-20.06.1956 (ZMH batch no. 444) Kovařík Paratype no. 88, 1 juvenile (ZMH-A0002208); (Kovařík Paratypes no. 26) 1 đै (ZMH-A0002205), India, [Uttarakhand], Himalaya, Timli [30²2'19'N, 7743'11'E], Siwalik [Siwālik Range] [30 $17^{\prime} 51^{\prime \prime N}, 77^{\circ} 47^{\prime} 41^{\prime \prime} \mathrm{E}$ ], 19.07.1956 (ZMH 02, batch no. 513), Deutsche Indien-Expedition 1955-557, G. A. von Maydell leg. (ZMH Eing. Nr 1, 1956); (Kovařík Paratypes no. 73) 1 subadult ô (ZMH-A0002200), India, [Uttarakhand], Himalaya, Chakrāta [3042'13'N, 7751'49'E], 19.06.1956 (ZMH 09, batch no. 448), Deutsh Indien Expedition 1955-57, G. A. von Maydell leg. (ZMH Eing. Nr 1, 1956).

Remarks. Other paratypes are deposited in the following institutions: BMNH (Kovařík Paratype 5: 1 male), SMFD (Kovař́k Paratype 6: one male), ZMB (Kovař́k Paratypes 7, 37: one male and one female), ROCC (Kovařík Paratype 8: one male), MZUF (Kovařík Paratype 9: one male), NMPC (Kovařík Paratypes 10, 36: one male and one female), MBCZ (Kovař́k Paratype 30: one female), MCSN (Kovařík Paratype 31: one female), FKCP (Kovař́k Paratypes 1-4, 27-29: four males, two females).

Remarks on collector. Gustav Adolf von Maydell led the German India-Expedition 1955-58, which was commissioned by the Zoological Institute and Museum of Hamburg (Oboussier and v. Maydell 1959, 1960 [see map for detail about collecting localities]; Brandon-Jones 2004 [estimated GPS coordinates of Molta: p. 1578]; 
A

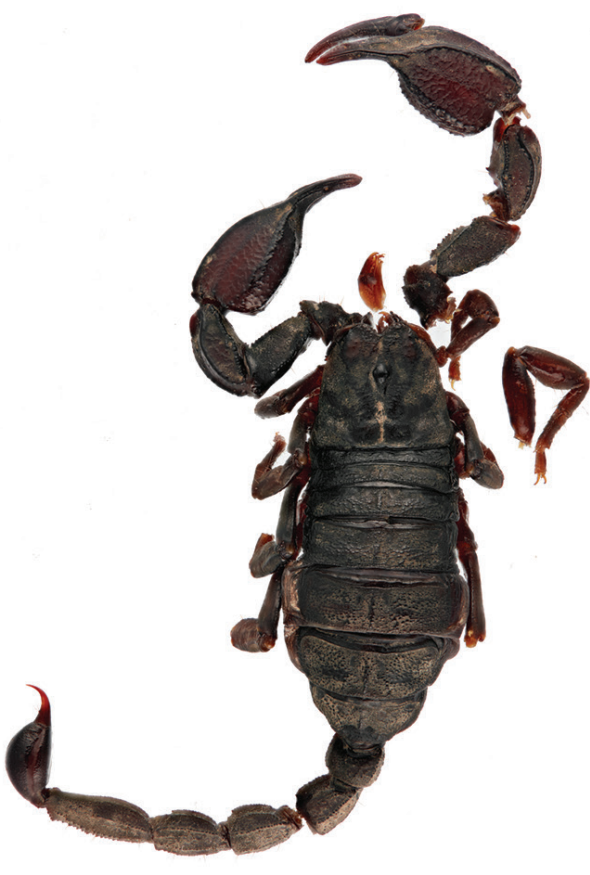

C

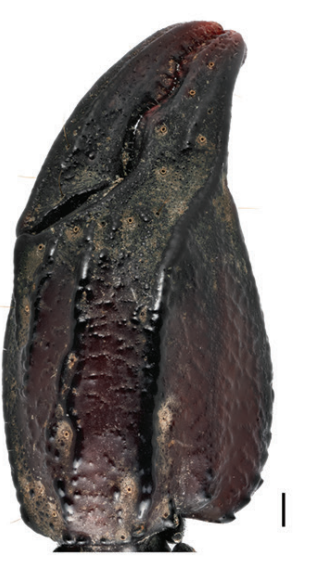

B

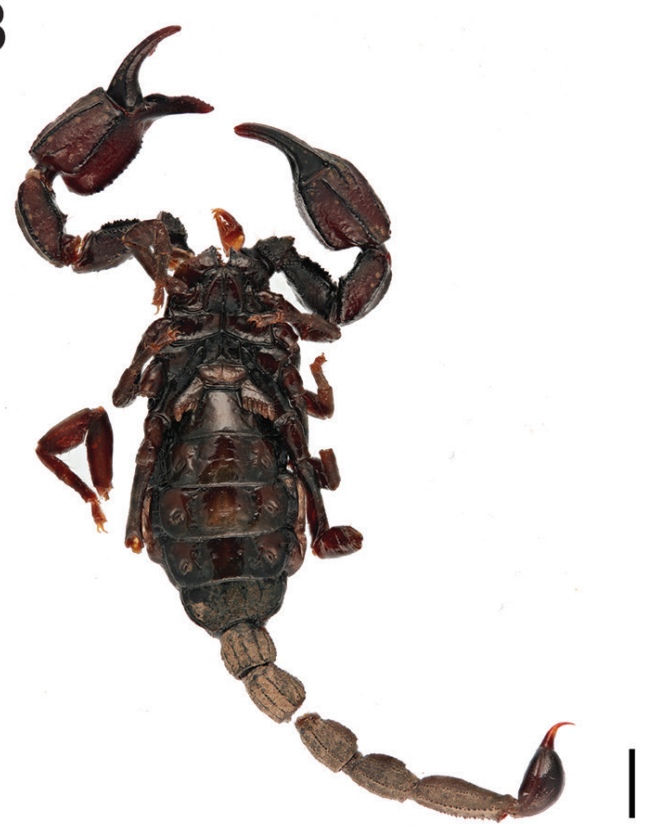

E
D

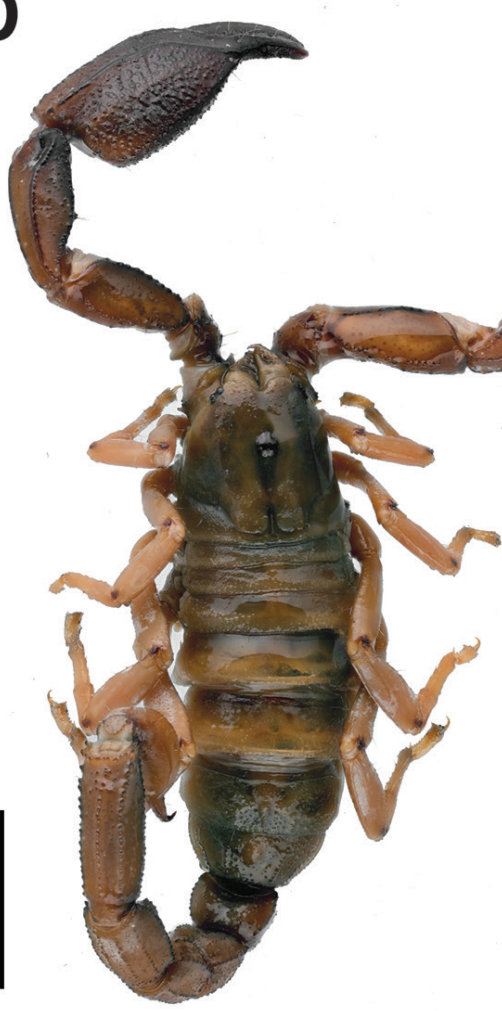

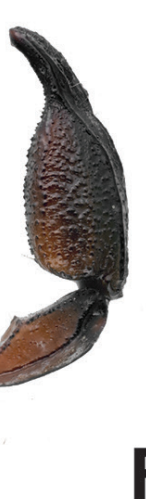

$\mathbf{F}$

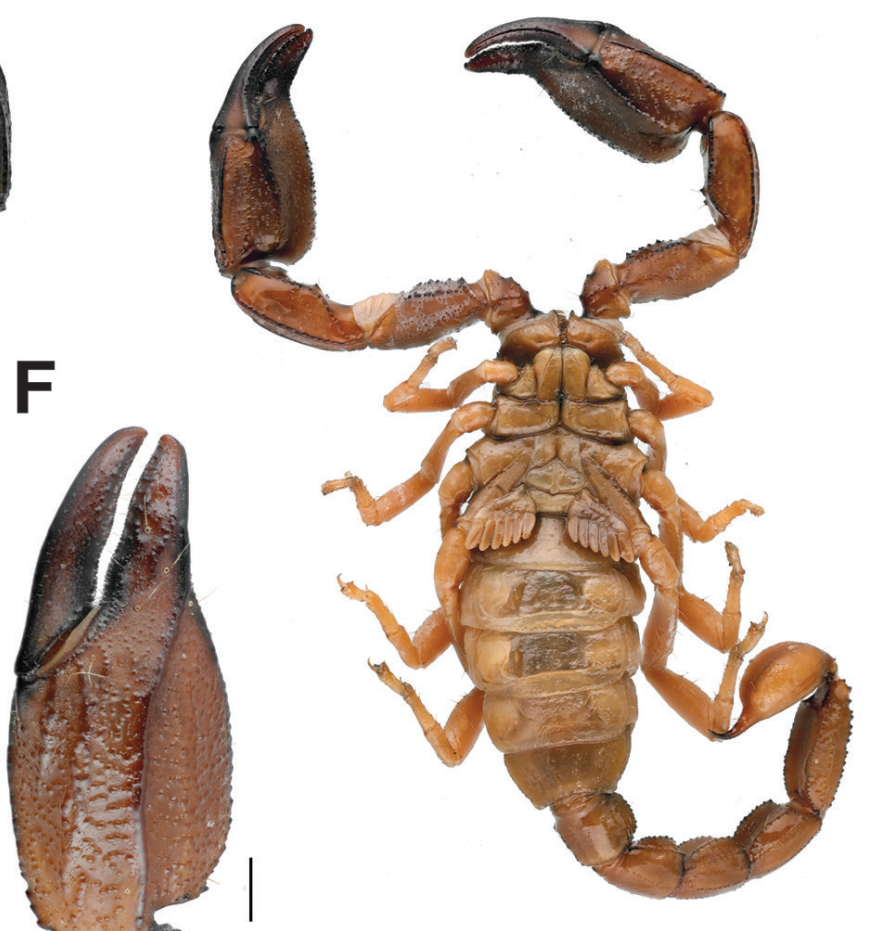

Figure 60. Scorpiops afghanus Lourenço \& Qi, 2006, female holotype (A-C). Scorpiops affinis Krapelin, 1898 [= Scorpiops hardwickii (Gervais, 1843)], male lectotype (D-F): A, D dorsal aspect of habitus B, E ventral aspect of habitus C, F retrolateral aspect of chela illustrating dentate margins of fingers. Scale bars: $10 \mathrm{~mm}(\mathbf{A}-\mathbf{B}), 5 \mathrm{~mm}(\mathbf{D}-\mathbf{E}), 1 \mathrm{~mm}(\mathbf{C}), 0.5 \mathrm{~mm}(\mathbf{F})$. 


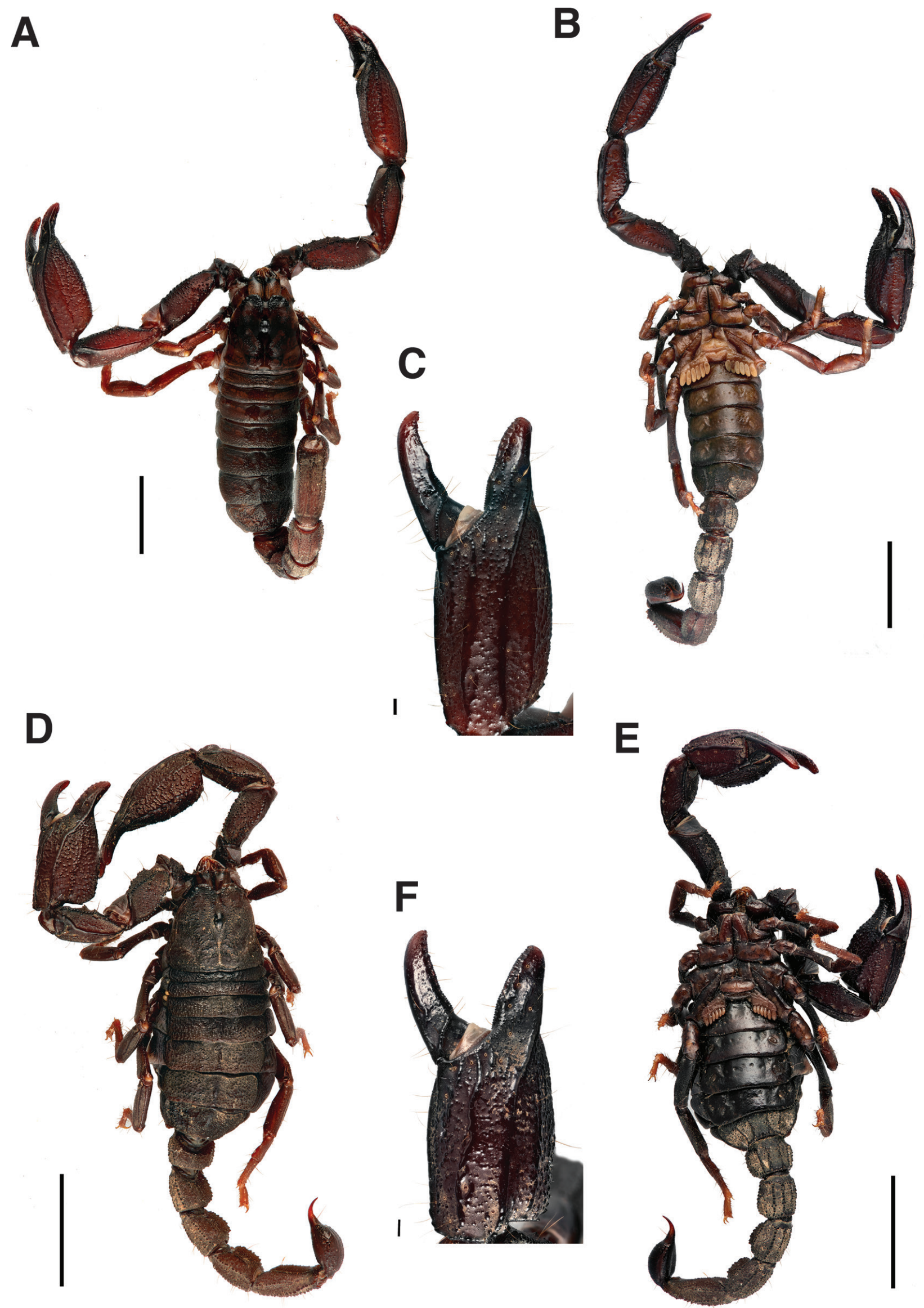

Figure 61. Scorpiops dastychi Kovařík 2000, male holotype (A-C), female paratype (D-F): A, D dorsal aspect of habitus B, E ventral aspect of habitus $\mathbf{C}, \mathbf{F}$ retrolateral aspect of chela illustrating dentate margins of fingers. Scale bars: $10 \mathrm{~mm}(\mathbf{A}-\mathbf{B}, \mathbf{D}-\mathbf{E}), 1 \mathrm{~mm}(\mathbf{C}, \mathbf{F})$. 
Grimm 2011). The botanical, zoological and ethnological material from his expedition was deposited in scientific institutions in Hamburg, but also in Wuppertal, Stuttgart and Bremen.

\section{Scorpiops feti}

Fig. 62

Scorpiops feti Kovařík, 2000: 174-175, 197, fig. 17, 36, 49, $54-55$, tab. $1-3$

Current combination. Scorpiops feti Kovařík, 2000

Holotype. (Fig. 62A-C) के (ZMH-A0001090), India, Sikkim [2745’00’N, 8³0’00’E], coll. 07.1913, Museum Calcutta don.

Paratypes. 1 q (Fig. 61D-F, ZMH-A000949); 1 (ZMH-A0001089); 1 ふ̄, 2 , 1 juvenile (ZMH-A0002189); 4 subadult $\precsim$ đ, 2 subadult $\propto$, 2 juveniles (ZMH-A0002190, A0002191), same data as holotype; + (ZMH-A000948), India, [Assam], Darang [Darrang] [2630'43”N, 92¹0’06”E], 10.1912, Museum Calcutta don; ô (ZMH-A002188), India, [Assam], Sibsāgar [Sivasagar] [2659’03”N, 94³8’16”E], 10.1912, Museum Calcutta don.

Remarks. Two paratypes (one male, one female) are deposited in FKCP.

\section{Scorpiops kraepelini}

Fig. 63

Scorpiops kraepelini Lourenço, 1998: 246, 248, 252-253, figs.1-9, 13

Current combination. Scorpiops kraepelini Lourenço, 1998

Holotype. (Fig. 63A-C) § (ZMH-A0000947), Pakistan, [Balouchistan Province], Loralai District, 14 miles E of Zirãt [Ziārat] [30²4'07'N, 6743'24'E], 06.1961, J. Anderson leg. (ZMH Eing. Nr. A28/98).

Paratype. (Fig. 63D-F) ㅇ (ZMH-A0000946), same data as holotype (ZMH Eing. Nr. A29/98).

\section{Family Urodacidae Pocock, 1893}

Type specimens belonging to three species are present at $\mathrm{ZMH}$.

\section{Genus Urodacus Peters, 1861}

\section{Urodacus bicolor}

Fig. $64 \mathrm{~A}-\mathrm{B}$

Urodacus bicolor Werner, 1936: 182-183, fig. 3

Current senior synonym. Urodacus novaehollandiae Peters, 1861 [synonymized by L. E. Koch 1977: 194]
Syntypes. 1 (Fig. 64A-B, ZMH-A0001081); 1 ㅇ (ZMH-A0002185), Western Australia, Pickering Brook [3202'51'S, 116 11 '54"E], Wilhelm Michaelsen leg., Hamburg's South-West Australia Expedition 1905 (ZMH, Eing. Nr. 4.1926).

Remarks. Werner (1936) reported a male and a female from Pickering Brook and a female from Upper Blackwood District, Brancaster (J. M. Whistler coll.). L. E. Koch (1977) examined the latter specimen and noted that it is a male contrary to Werner (1936) and listed it as a syntype of $U$. bicolor lodged in the ZMH. Koch also studied the specimens from Pickering Brook and determined them as male and female syntypes of $U$. bicolor. The specimen from Brancaster could not be found in the collection of the $\mathrm{ZMH}$ and may be lost. Given the discrepancies between the sexes of the specimens examined and the sexes reported by previous workers, we decided not to designate a lectotype. The male reported by Werner and Koch should ideally be designated as lectotype but the specimen could not be found during the course of this work.

Remarks on collector. See paragraph on Cercophonius granulosus Kraepelin, 1908 above.

\section{Urodacus fossor}

Fig. $64 \mathrm{C}-\mathrm{D}$

Urodacus fossor Kraepelin, 1916: 36-39, fig. 6-7

Current senior synonym. Urodacus yaschenkoi (Birula, 1903) [synonymized by L. E. Koch 1977: 292]

Syntype. ㅇ (ZMH-A0000943), Australia, Streeters

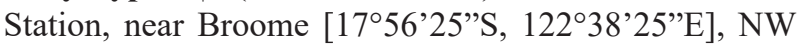
Australia, ex. 1912, Eric Mjöberg leg. (6/811, de dagbokon [the diary]).

Remarks. Kraepelin (1916) reported two females, one from Broome and one from Streeters Station. The present specimen was examined and designated as syntype by L. E. Koch (1977). The second specimen cannot be found in the ZMH collection and is possibly housed in the Natural History Museum in Stockholm. Kraepelin also mentioned in the original description that these scorpions were found in burrows which are four feet deep, have a spiraling shape and a half-moon cross-section, hence their name.

Remarks on collector. Eric Georg Mjöberg (18821938) was a Swedish zoologist and ethnographer who led the first Swedish scientific expeditions to Australia in the early 1900s (Mjöberg 1915; Musgrave 1932). Mjöberg travelled to Australia again in 1912-1913, exploring the Queensland Wet Tropics. From 1920 onwards, he established himself in Indonesia, working as chief of the Zoological Department for the Deli Experimental Station (Medan, Sumatra) from 1919 to 1922, then as curator of the Sarawak State Museum (Borneo) from 1922 to 1924 , finally leading an expedition to Central Borneo in 1925-1926. 
A

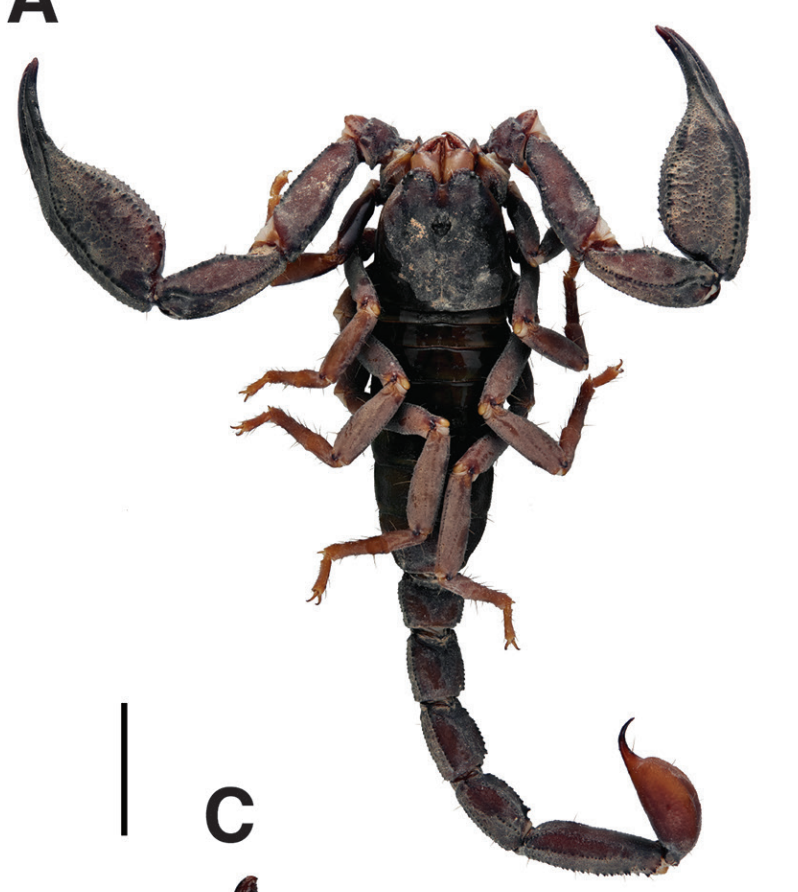

B
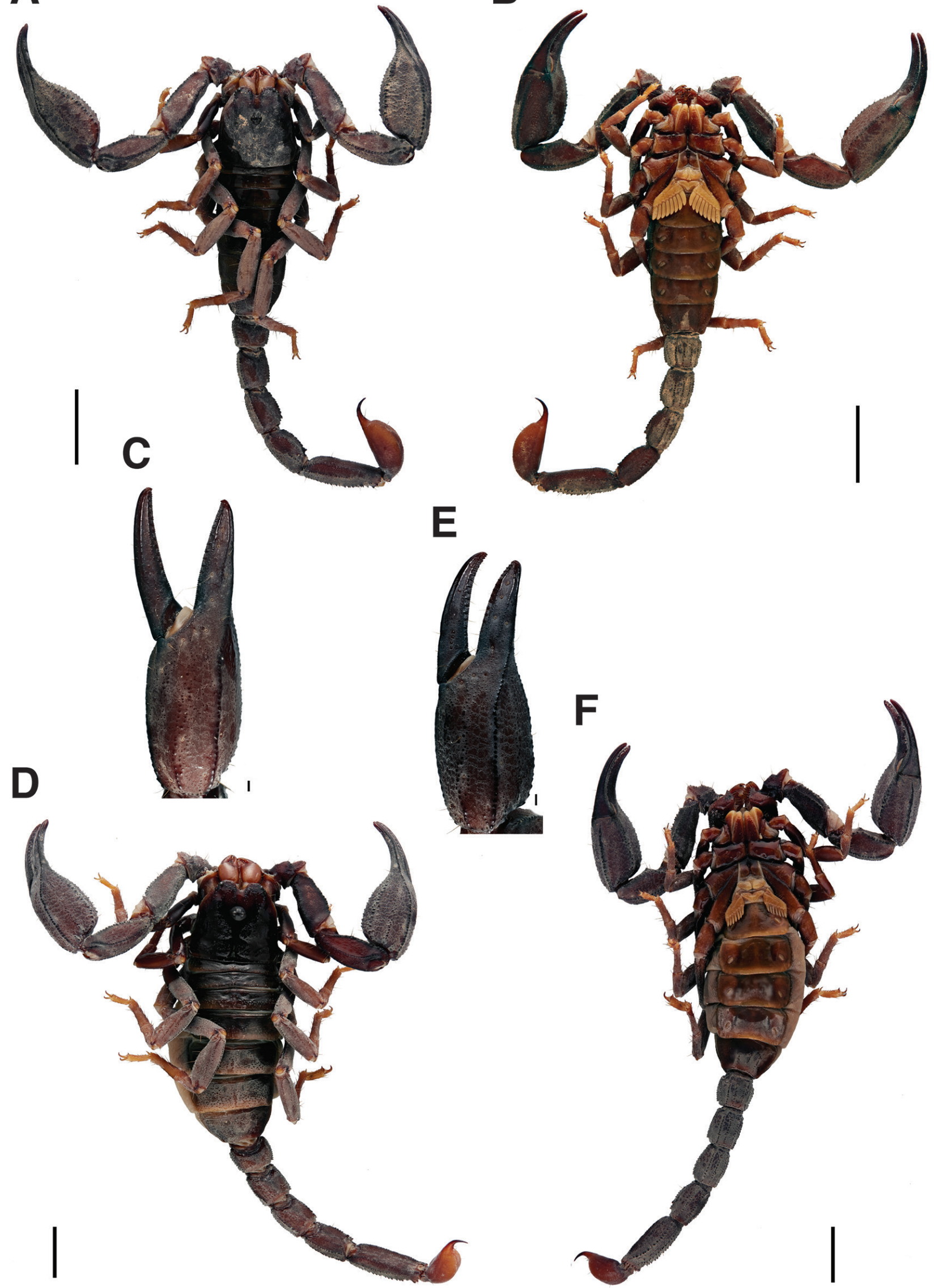

Figure 62. Scorpiops feti Kovařík, 2000, male holotype (A-C), female paratype (D-F): A, D dorsal aspect of habitus B, E ventral aspect of habitus $\mathbf{C}, \mathbf{F}$ retrolateral aspect of chela illustrating dentate margins of fingers. Scale bars: $10 \mathrm{~mm}(\mathbf{A}-\mathbf{B}, \mathbf{D}-\mathbf{E}), 1 \mathrm{~mm}(\mathbf{C}, \mathbf{F})$. 
A

B

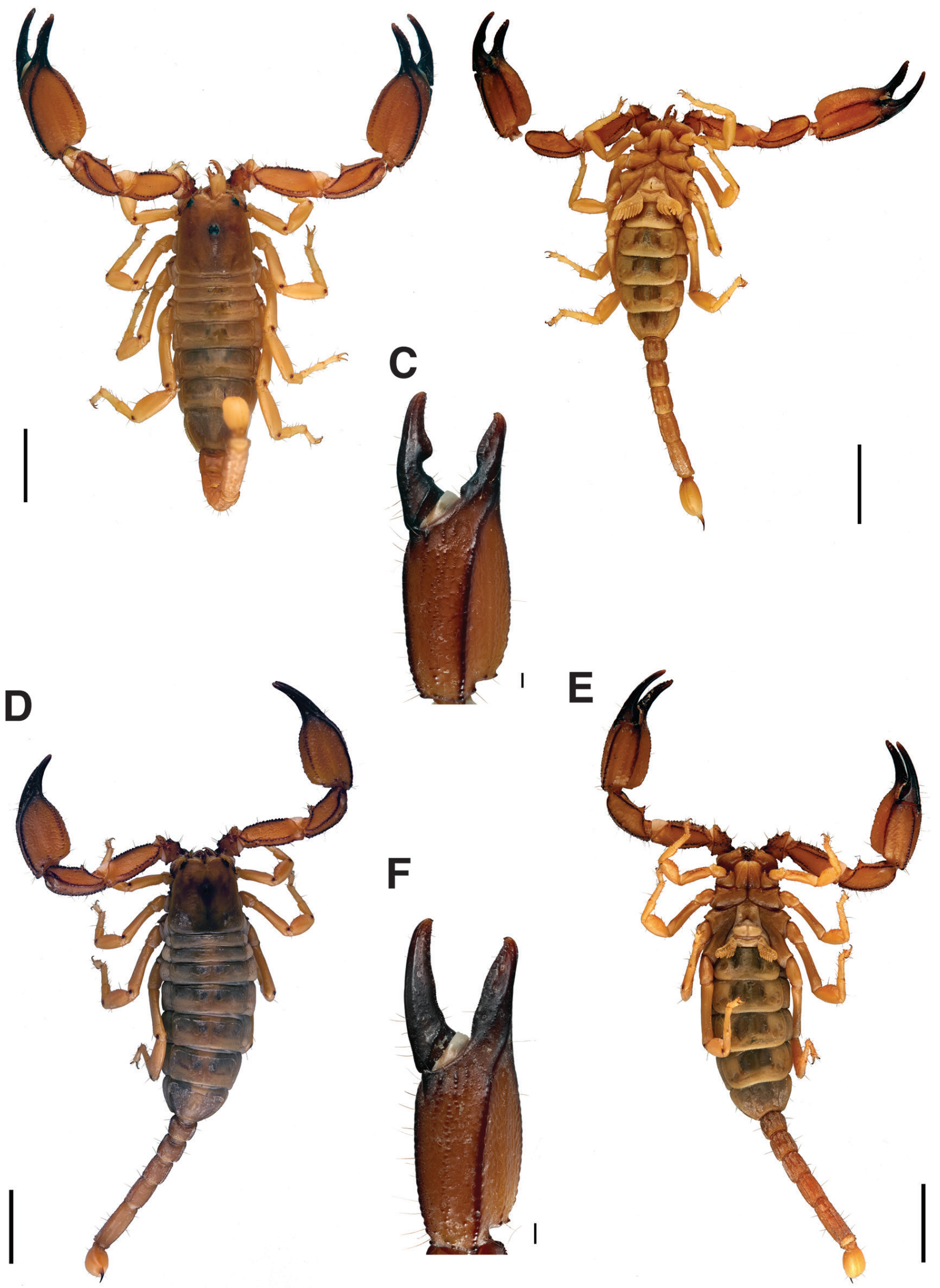

Figure 63. Scorpiops kraepelini Lourenço, 1998, male holotype (A-C), female paratype (D-F): A, D dorsal aspect of habitus B, E ventral aspect of habitus $\mathbf{C}, \mathbf{F}$ retrolateral aspect of chela illustrating dentate margins of fingers. Scale bars: $10 \mathrm{~mm}(\mathbf{A}-\mathbf{B}, \mathbf{D}-\mathbf{E}), 1 \mathrm{~mm}(\mathbf{C}, \mathbf{F})$. 

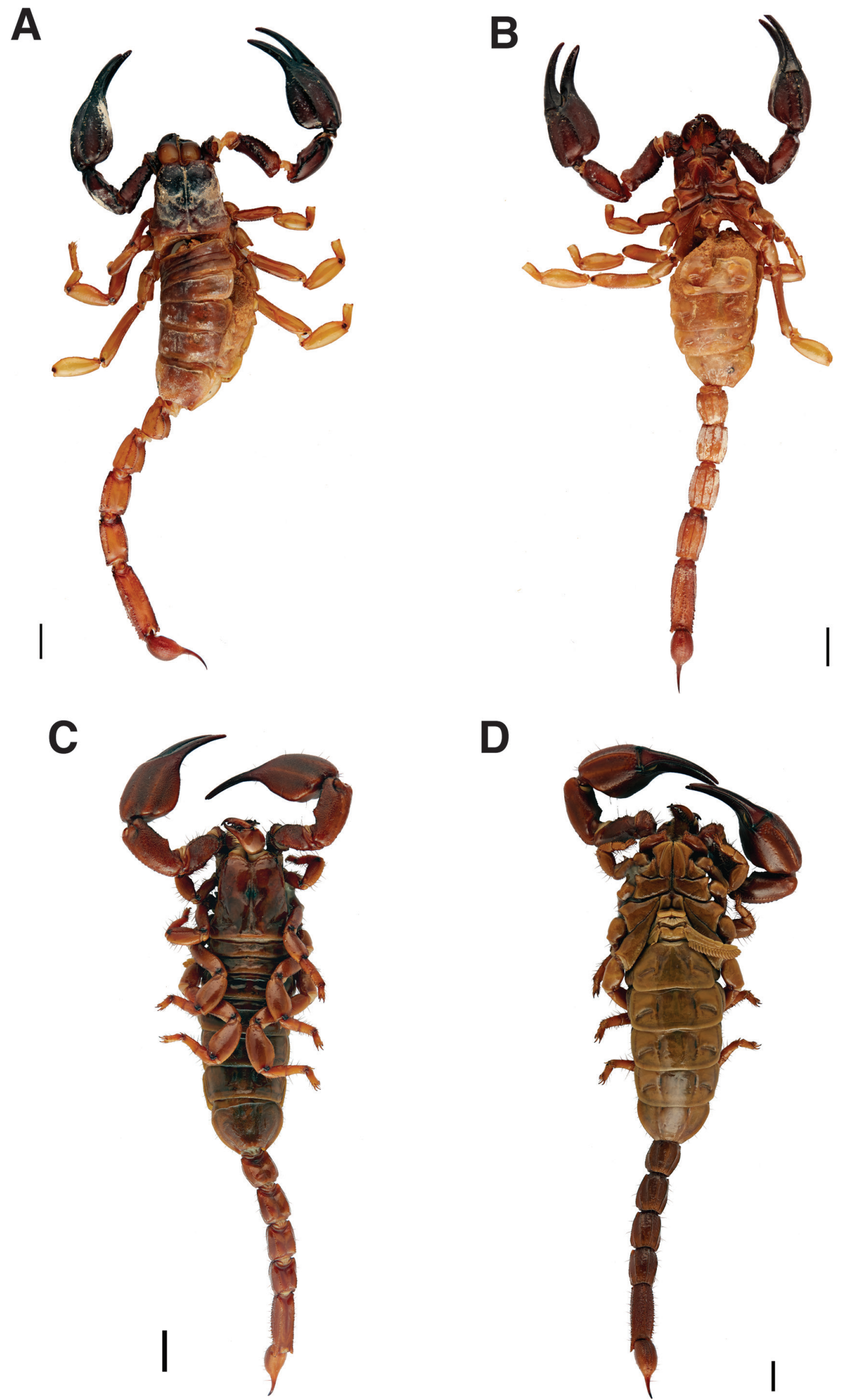

$D$

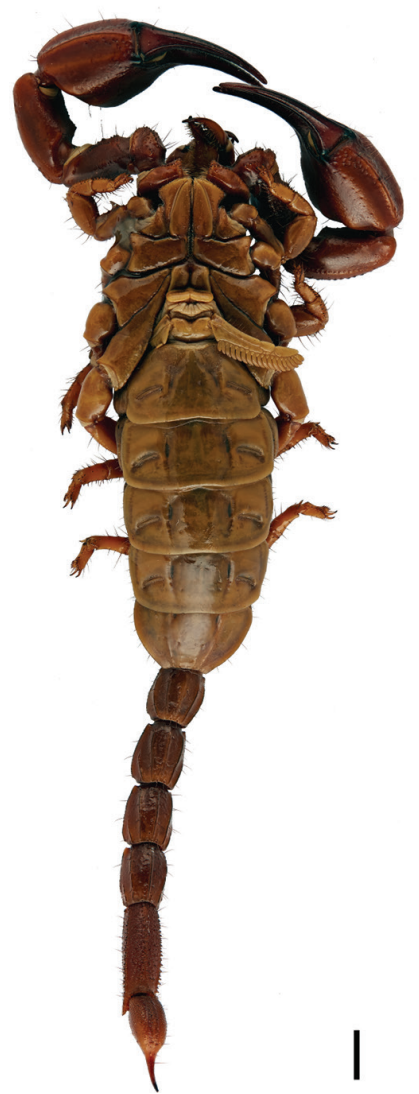

Figure 64. Urodacus bicolor Werner, 1936 [= Urodacus novaehollandiae Peters, 1861], female syntype (A-B). Urodacus fossor Kraepelin, 1916 [= Urodacus yaschenkoi (Birula, 1903)], female syntype (C-D): A, C dorsal aspect of habitus B, D ventral aspect of habitus. Scale bars: $10 \mathrm{~mm}$. 


\section{Urodacus hartmeyeri}

Fig. 65

Urodacus hartmeyeri Kraepelin, 1908c: 99-101, pl. XII, fig. 7-9

Current combination. Urodacus hartmeyeri Kraepelin, 1908.

Lectotype. (Fig. 65A-B) 9 (ZMH-A0000936), Western Australia, Tamala (station 70) [26 41 '53”S, $\left.113^{\circ} 42^{\prime} 57^{\prime \prime} \mathrm{E}\right], \mathrm{S}$ of Shark Bay, 07-08.09.1905, Robert Hartmeyer leg., Hamburg's South-West Australia Expedition 1905.

Paralectotype. + (ZMH-A0000936), same data as lectotype.

Remarks. The bigger female is designated lectotype, the other female is paralectotype.

Remarks on collector. Heinrich Hermann Robert Hartmeyer (1874-1923) was a German zoologist. He was curator at the Zoological Museum of the University of Berlin from 1908 onward (Jahn 1969). He led a major expedition to South-Western Australia in 1905 with W. Michaelsen (see paragraph on Cercophonius granulosus Kraepelin, 1908 above for detail).

\section{Superfamily Vaejovoidea Thorell, 1876}

Type specimens belonging to one species are present at $\mathrm{ZMH}$.
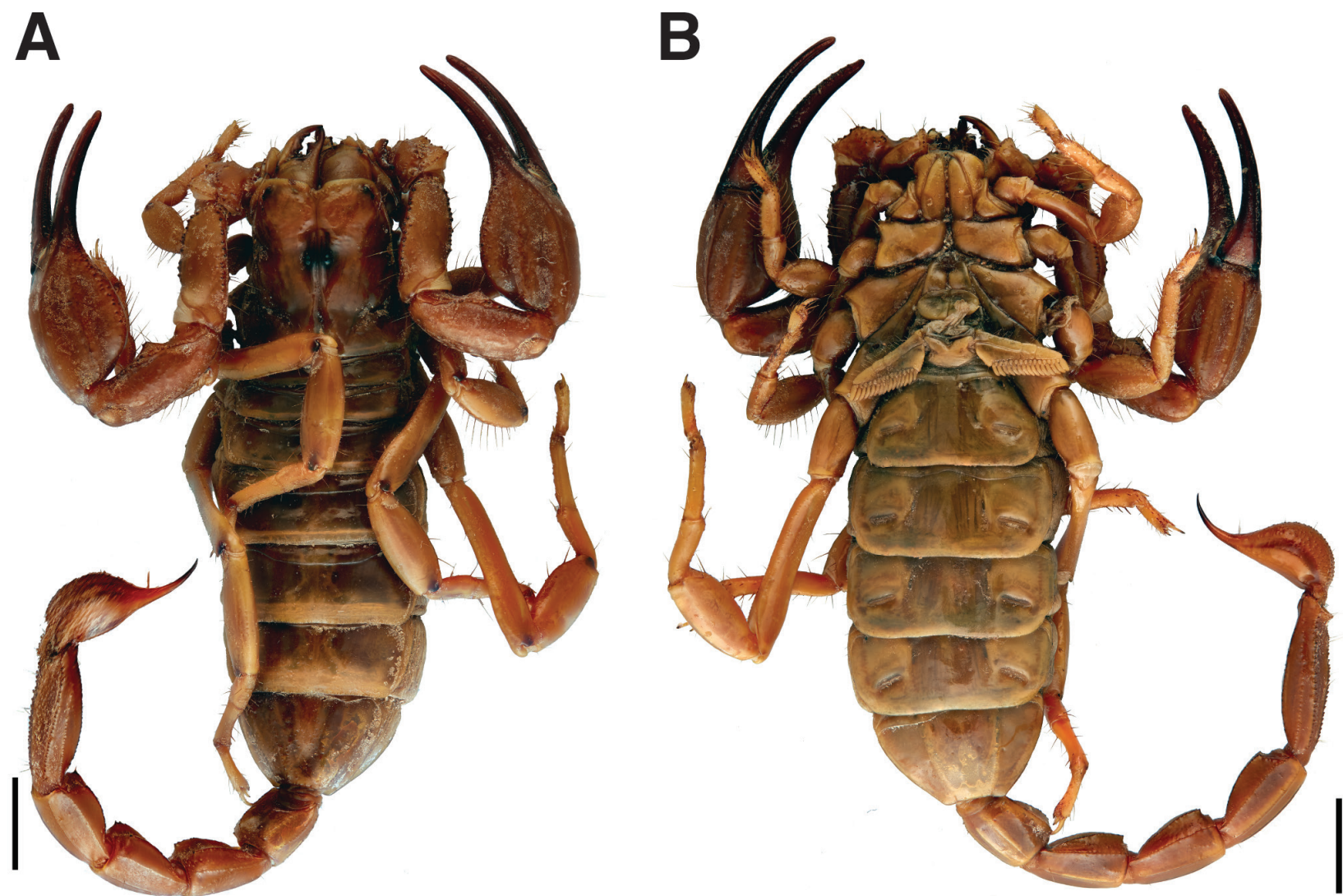

Figure 65. Urodacus hartmeyeri Kraepelin, 1908, female lectotype, habitus A dorsal aspect B ventral aspect. Scale bars: $10 \mathrm{~mm}$ 

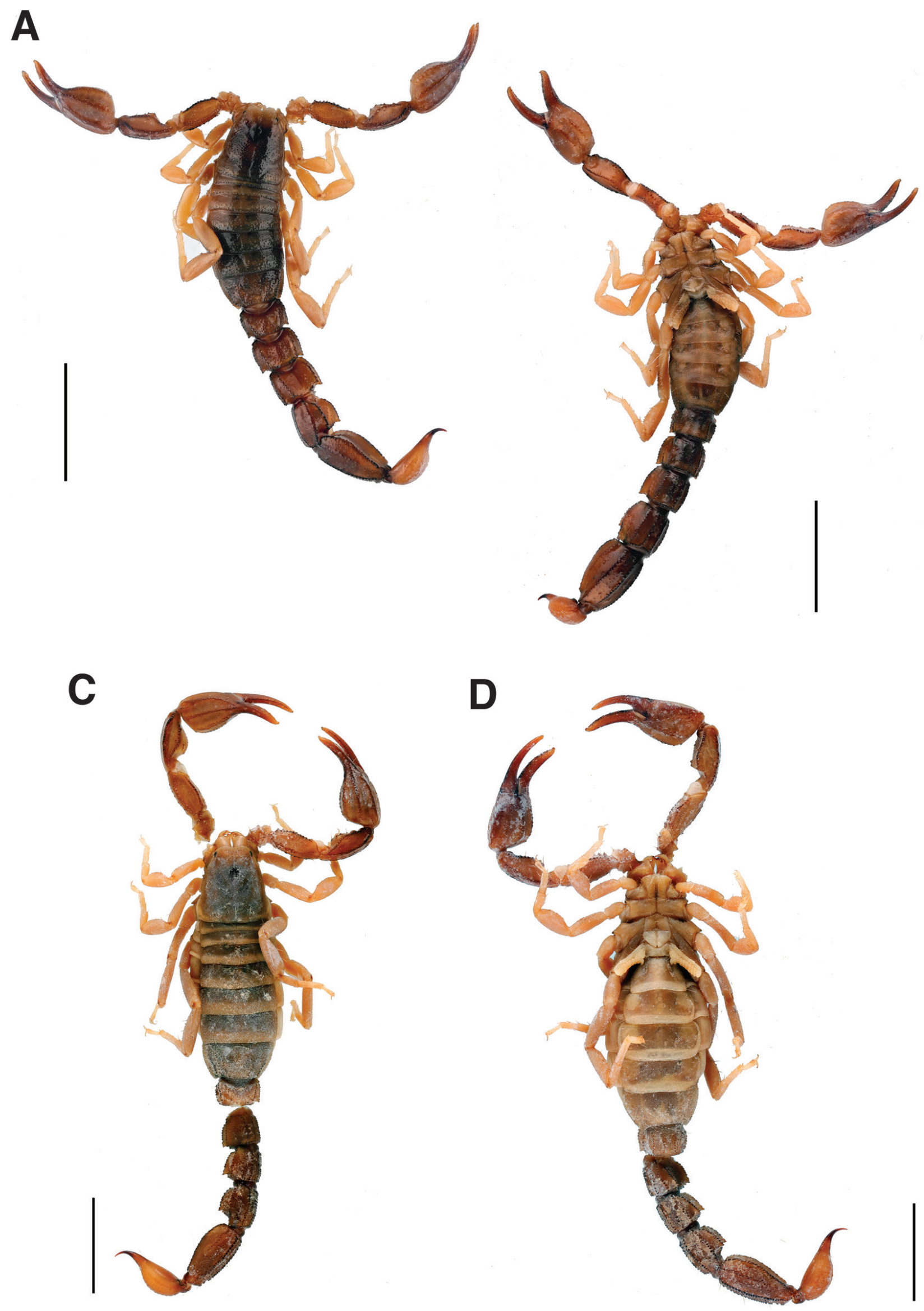

Figure 66. Vejovis minimus Kraepelin, 1911 [= Catalinia minima (Kraepelin, 1911)], male paralectotype (A-B), female lectotype (C-D): A, C dorsal aspect of habitus B, D ventral aspect of habitus. Scale bars: $5 \mathrm{~mm}$. 


\section{Acknowledgements}

This study was funded by the "Gesellschaft der Freunde und Förderer des Zoologischen Museums Hamburg". We thank Elicio Tapia for imaging most specimens for this catalogue. L. Monod is grateful to Christina Lehman-Graber for her help in editing the photographs of Hormurus boholiensis, Hormurus karschii keyensis and Hormurus papuanus, and John Hollier and Peter Schwendinger for their suggestions and constructive comments. Finally, we would like to acknowledge Victor Fet, František Kovařík and Pedro Sousa for reviewing the manuscript.

\section{References}

Acosta LE (1990) El genero Cercophonius Peters, 1861 (Scorpiones, Bothriuridae). Boletin de la Sociedad de Biologia de Concepcíon 61: 7-27.

Anonymous (1912) Eugene William Oates. Ibis 54(2): 341-351. https:// doi.org/10.1086/330925

Anonymous (1970) Carl Rathjens, 10.3.1887-29.7.1966. Der Islam 46(1): 55-63. https://doi.org/10.1515/islm.1970.46.1.55

Barriga-Tũńon JE, Ugarte-Peña F (1995) Luis E. Peña G. (1921-1995). Revista Chilena de Entomología 22: 95-98.

Beentje HJ (1998) J M. Hildebrandt (1847-1881): Notes on his travels and plant collections. Kew Bulletin 53(4): 835-856. https://doi. org $110.2307 / 4118872$

Berthold S (1846) Ueber drei neue Scorpionenarten Neu-Granadas. Nachrichten von der Königlichen Gesellschaft der Wissenschaften und der Georg-Augusts Universität zu Göttingen 34: 56-67.

Bragg PE (2007) Biographies of Phasmatologists - 3. Hermann Burmeister. Phasmid Studies 16(1): 1-4.

Brancsik K (1893) Beiträge zur Kenntnis Nossibés und dessen Fauna nach Sendungen und Mittheilungen des Herrn P. Frey. Jahresheft des Naturwissenschaftlichen Vereines des Trencsiner Komitäts 15: 202-258.

Brandon-Jones D (2004) A taxonomic revision of the langurs and leaf monkeys (Primates: Colobinae) of South Asia. Zoos's Print Journal 19(8): 1552-1594. https://doi.org/10.11609/JoTT.ZPJ.971.1552-94

Couzijn HWC (1981) Revision of the Genus Heterometrus Hemprich \& Ehrenberg (Scorpionidae, Arachnida). E. J. Brill, Leiden, 196 pp. Dammerman, KW (1945) A history of the Visitors' Laboratory (“Treub Laboratorium") of the Botanic Gardens Buitenzorg, 1884-1934. In: Honig P, Verdoorn F (Eds) Science and Scientists in the Netherlands Indies. Board for the Netherlands Indies, New York, 5975. [Reprinted from Annales du Jardin Botanique de Buitenzorg 45(1935): 1-54.]

Delachaux T, Baer JG (1914) Otto Fuhrmann: 1871-1945. Bulletin de la Société Neuchâteloise des Sciences Naturelles 69: 147-167.

Dupérré N, Harms D (2018) Raising the Dead: Rediscovery and redescription of some lost spider types (Araneae) described by Eugène Simon. Evolutionary Systematics 2: 1-20. https://doi.org/10.3897/ evolsyst.2.24122

Fet V (2000a) Family Ischnuridae Simon, 1879. In: Fet V, Sissom WD, Lowe G, Braunwalder ME (Eds) Catalog of the Scorpions of the World (1758-1998). The New York Entomological Society, New York, 383-408.
Fet V (2000b) Family Heteroscorpionidae Kraepelin, 1905. In: Fet V, Sissom WD, Lowe G, Braunwalder ME (Eds) Catalog of the Scorpions of the World (1758-1998). The New York Entomological Society, New York, 381-382.

Fet V (2000c) Family Scorpionidae Latreille, 1802. In: Fet V, Sissom WD, Lowe G, Braunwalder ME (Eds) Catalog of the Scorpions of the World (1758-1998). The New York Entomological Society, New York, 427-486.

Fet V, Sissom WD, Lowe G, Braunwalder ME (2000) Catalog of the Scorpions of the World (1758-1998). New York Entomological Society, New York, 690 pp.

Fischer GA (1885a) Bericht über die im Auftrage der Geographischen Gesellschaft in Hamburg unternommene Reise in das Massai-Land, I, Allgemeiner Bericht. Mitteilungen der geographischen Gesellschaft in Hamburg 5(1882-1883): 36-99.

Fischer GA (1885b) Bericht über die im Auftrage der Geographischen Gesellschaft in Hamburg unternommene Reise in das Massai-Land, II, Begleitworte zur Original-Routenkarte Tafel VII. Mitteilungen der geographischen Gesellschaft in Hamburg 5(1882-1883): 189-237.

Fischer GA (1885c) Übersicht der in Ostafrika gesammelten Vogelarten, mit Angabe der verschiedenen Fundorte. Journal für Ornithologie 13(170): 113-142. https://doi.org/10.1007/BF02029096

Forcart L (1961) Katalog des Typusexemplare in der Arachnida-Sammlung des Naturhistorischen Museums zu Basel: Scorpionidea, Pseudoscorpionidea, Solifuga, Opilionidea und Araneida. Verhandlungen der Naturforschenden Gesellshaft in Basel 72: 47-87.

Francke OF (1978) Systematic revision of diplocentrid scorpions (Diplocentridae) from circum-Caribbean lands. Special Publications of the Museum, Texas Tech University 14: 1-92. https://doi. org/10.5962/bhl.title.156481

Francke OF, Stockwell SA (1987) Scorpions (Arachnida) of Costa Rica. Special Publications of the Museum, Texas Tech University 25: 1-64. https://doi.org/10.5962/bhl.title.156482

Fülleborn F (1906) Das Deutsche Njassa- und Ruwuma-Gebiet, Land und Leute, nebst Bemerkungen über die Schire-Länder: mit benutzung von Ergebnissen der Njassa- und Kingagebirgs-Expedition der Hermann und Elise geb. Heckmann Wentzel-Stiftung (1906). Dietrich Reimer, Berlin, 636 pp.

Fuhrmann O, Mayor E (1914) Voyage d'exploration scientifique en Colombie. Mémoires de la Société neuchâteloise des Sciences naturelles 5, Attinger Frères, Neuchâtel, 1090 pp. https://doi. org/10.5962/bhl.title.46309

Garth JS (1957) Reports of the Lund University Chile Expedition 1948-49. 29. The Crustacea Decapoda Brachuyura of Chile. Lunds Universitets Arsskrift, N.F. Avd. 2 53(7): 1-131.

Gertsch WJ, Soleglad M (1972) Studies of North American scorpions of the genera Uroctonus and Vejovis (Scorpionida, Vejovidae). Bulletin of the American Museum of Natural History 148(4): 547-608.

Giltay L (1931) Scorpions et pédipalpes. Résultats scientifiques du voyage aux Indes Orientales Néerlandaises de LL. AA. RR. le Prince et la Princesse Léopold de Belgique. Mémoires du Musée Royal d'histoire naturelle de Belgique, Hors série 3(6): 1-28.

Gregory JW (1896) The Great Rift Valley, Being the Narrative of a Journey to Mount Kenya and Lake Baringo, With Some Account of the Geology, Natural History, Anthropology, and Future Prospects of British East Africa. John Murray, London, 422 pp. https://doi. org/10.5962/bhl.title.12499 
Grimm R (2011) Die Deutsche Indien-Expedition 1955-1958: unter Leitung von Gustav Adolf Baron von Mandel. Abhandlungen des Naturwissenschaftlichen Vereins in Hamburg 42, Dölling \& Galitz Verlag, München, $256 \mathrm{pp}$.

Gutsche A, Kwet A, Kucharzewski C, Lingnau R, Günther R (2007) Wilhelm Ehrhardt and an evaluation of his amphibians and reptiles held in the Herpetological Collection of the Museum für Naturkunde, Berlin. Mitteilungen aus dem Museum für Naturkunde in Berlin-Zoologische Reihe 83(1): 80-93. https://doi.org/10.1002/ mmnz.200600019

Habel JC, Husemann M, Finger A, Danley PD, Zachos FE (2013) The relevance of time series in molecular ecology and conservation biology. Biological Reviews 89: 484-492. https://doi.org/10.1111/brv.12068

Harms D, Dupérré N (2018) An annotated type catalogue of the camel spiders (Arachnida: Solifugae) held in the Zoological Museum Hamburg. Zootaxa 4375: 1-58. https://doi.org/10.11646/zootaxa.4375.1.1

Hewitt J (1914) Description of new Arachnida from South Africa. Records of the Albany Museum 3: 1-37. https://doi.org/10.5962/bhl. part. 7433

Hewitt J (1918) A survey of the scorpion fauna of South Africa. Transactions of the Royal Society of South Africa 6: 89-192. https://doi. org/10.1080/00359191809520177

JWG (1907) German Nyasa and Rovuma Lands. The Geographical Journal 30(1): 81-83. https://doi.org/10.2307/1776410

Jahn I (1969) Heinrich Robert Hartmeyer. Neue deutsche Biographie 8: 6-7. [Hartmann - Heske, Berlin]

Jessop JP (1964) Itinerary of Rudolf Schlechter's collecting trips in Southern Africa. Journal of South African Botany 30: 129-142.

Koch L (1867) Beschreibungen neuer Arachniden und Myriapoden. Verhandlungen der Zoologisch-Botanischen Gesellschaft in Wien 17: $173-250$.

Koch LE (1977) The taxonomy, geographic distribution and evolutionary radiation of Australo-Papuan scorpions. Records of the Western Australian Museum 5: 83-367.

Kovařík F (2000) Revision of the family Scorpiopidae (Scorpiones), with descriptions of six new species. Acta Societatis Zoologicae Bohemicae 64: 153-201.

Kovařík F (2004) A review of the genus Heterometrus Ehrenberg, 1828, with descriptions of seven new species (Scorpiones, Scorpionidae). Euscorpius 15: 1-60. https://doi.org/10.18590/euscorpius.2004. vol2004.iss 15.1

Kovařík F (2009) Illustrated Catalog of Scorpions. Part I. Clairon Production, Prague, 169 pp.

Kovařík F, Ojanguren Affilastro AA (2013) Illustrated Catalog of Scorpions. Part II. Clairon Production, Prague, 398 pp.

Kraepelin K (1883) Zur Anatomie Physiologie des Rüssels von Musca. Zeitschrift für Wissenschaftliche Zoologie 39: 683-719. [682 plates]

Kraepelin K (1884) Über die Systematische Stellung der Puliciden. Paper Presented at the Festschrift zur Feier des 50 jährigen Bestehens des Realgymnasiums des Johanneums in Hamburg veröffentlicht am 28. März 1884 (1834-1884), Hamburg.

Kraepelin K (1886) Die Fauna der Hamburger Wasserleitungen. Abhandlungen aus dem Gebiete der Naturwissenschaften 9: 3-8.

Kraepelin K (1887) Die deutschen Süsswasser-Bryozoen, Eine Monografie, I, Anatomische-systematischer Teil. Abhandlungen des Naturwissenschaftlichen Vereins in Hamburg 10: 1-168. [pls. 1-7]

Kraepelin K (1891a) Abriss der Geschichte des Naturhistorischen Museums zu Hamburg. Erinnerungsblatt an die Wieder-Eröffnung des
Naturhistorischen Museums zu Hamburg im neuen Gebäude am Steinthorwall am 17. September 1891: 1-41. [pls. 1-13]

Kraepelin K (1891b) Revision der Skorpione, I, Die Familie der Androctonidae. Jahrbuch der Hamburgischen Wissenschaftlichen Anstalten 8: 1-144.

Kraepelin K (1892) Die deutschen Süßwasserbryozoen, Eine Monographie, II, Eintwicklungsgeschichtlicher Teil. Abhandlungen des Naturwissenschaftlichen Vereins in Hamburg 12: 1-67.

Kraepelin K (1894) Revision der Scorpione, II, Scorpionidae und Bothriuridae. Beiheft zum Jahrbuch der Hamburger Wissenschaftlichen Anstalten 11: 1-248.

Kraepelin K (1895a) Nachtrag zu Theil I der Revision der Scorpione. Beiheft zum Jahrbuch der Hamburger Wissenschaftlichen Anstalten 12: 73-96.

Kraepelin K (1895b) 7. Naturhistorisches Museum, Bericht des Direktors Professors Dr. K. Krapelin. Jahrbuch der Hamburgischen Wissenschaftlichen Anstalten 8: 80-89.

Kraepelin K (1896a) Phalangiden aus der Umgebung Hamburgs. Mittheilungen aus dem Naturhistorischen Museum, Beiheft zum Jahrbuch der Hamburgischen Wissenschaftlichen Anstalten 13: 219-233.

Kraepelin K (1896b) Neue und weniger bekannte Skorpione. Mittheilungen aus dem Naturhistorischen Museum, Beiheft zum Jahrbuch der Hamburgischen Wissenschaftlichen Anstalten 13: 119-146.

Kraepelin K (1897a) Revision der Uropygi Thor. (Thelyphonidae auct.). Abhandlungen aus dem Gebiete der Naturwissenschaften herausgegeben vom Naturwissenschaftlichen Verein in Hamburg 15: 1-58.

Kraepelin K (1897b) Scorpione und Thelyphoniden. Abhandlungen der Senckenbergischen Naturforschenden Gesellschaft 23(3): 1 pp.

Kraepelin K (1898a) Neue Pedipalpen und Scorpione des Hamburger Museums. Mitteilungen aus dem Naturhistorischen Museum in Hamburg, Beiheft zum Jahrbuch der Hamburgischen Wissenschaftlichen Anstalten 15: 39-44.

Kraepelin K (1898b) Die Skorpione Ost-Afrikas. In: Möbius K (Ed.) Die Thierweld Ost-Afrikas und der Nachbargebiete [Vol. 4.] Reimer, Berlin, 1-5.

Kraepelin K (1898c) Über die Linné'schen Arten der Gattung Scorpio. Zoologischer Anzeiger 564/565: 438-447.

Kraepelin K (1899a) Scorpiones und Pedipalpi. Das Tierreich 8, Verlag von R. Friedländer and Sohn, Berlin, 265 pp.

Kraepelin K (1899b) Catalogue des Solifuges (?) des collections du Muséum d'histoire Naturelle de Paris. Bulletin du Muséum d'Histoire Naturelle, Paris 5: 376-378.

Kraepelin K (1899c) Zur Systematik der Solifugen. Mitteilungen aus dem Naturhistorischen Museum in Hamburg 16: 195-258.

Kraepelin K (1900) Ueber einige neue Gliederspinnen. Abhandlungen aus dem Gebiete der Naturwissenschaften Verein, Hamburg 16: $1-17$.

Kraepelin K (1901a) Das Naturhistorische Museum. In: Hamburg in naturwissenschaftlicher und medizinischer Beziehung. Herausgegeben zur 73. Versammlung Deutscher Naturforscher und Ärzte. Verlag von Leopold Voss, Hamburg, 124-149.

Kraepelin K (1901b) Ueber die durch den Schiffsverkehr in Hamburg eingeschleppten Tiere. Mitteilungen aus dem Naturhistorischen $\mathrm{Mu}-$ seum in Hamburg 18: 183-209.

Kraepelin K (1901c) Die Fauna der Umgegend Hamburgs. Verlag von Leopold Voss, Hamburg, 26 pp.

Kraepelin K (1901d) Palpigradi und Solifugae. Das Tierreich 12, Verlag von R. Friedländer and Sohn, Berlin, 159 pp. 
Kraepelin K (1901e) Catalogue des scorpions des collections du Museum d'histoire Naturelle de Paris. Bulletin du Muséum d'Histoire Naturelle, Paris 7: 265-274.

Kraepelin K (1901f) Catalogue des Pédipalpes des collections du Muséum d'Histoire Naturelle de Paris. Bulletin du Muséum National d'Histoire Naturelle, Paris 7: 263-264.

Kraepelin K (1903a) Revision der Scolopendriden. Mitteilungen aus dem Naturhistorischen Museum (2. Beiheft zum Jahrbuch der Hamburgischen Wissenschaftlichen Anstalten) 20: 1-276.

Kraepelin K (1903b) Scorpione und Solifugen Nordost-Afrikas, gesammelt 1900 und 1901 von Carlo Freiherrn von Erlanger und Oscar Neumann. Zoologische Jahrbücher, Abtheilung für Systematik, Geographie und Biologie der Thiere 18: 557-578.

Kraepelin K (1904) Zur Nomenklatur der Skorpione und Pedipalpen. Zoologischer Anzeiger 28: 195-204.

Kraepelin K (1905) Die geographische Verbreitung der Skorpione. Zoologische Jahrbücher, Abtheilung für Systematik, Geographie und Biologie der Thiere 22: 321-364.

Kraepelin K (1908a) Scolopendridae. In: Michaelsen W, Hartmeyer R (Eds) Die Fauna Südwest-Australiens, Ergebnisse der Hamburger Südwest-Australischen Forschungsreise 1905. [Vol. 2.] Verlag Gustav Fischer, Jena, 105-128.

Kraepelin K (1908b) Die sekundären Geschlechtscharaktere der Skorpione, Pedipalpen und Solifugen. Mitteilungen aus dem Naturhistorischen Museum in Hamburg 25: 182-225.

Kraepelin K (1908c) Scorpiones. In: Michaelsen W, Hartmeyer R (Eds) Die Fauna Südwest-Australiens, Ergebnisse der Hamburger Südwest-Australischen Forschungsreise 1905. [Vol. 2.] Verlag Gustav Fischer, Jena, 87-104.

Kraepelin K (1908d) Skorpione und Solifugen. In: Schultze L (Ed.) Forschungsreise im westlichen und zentralen Südafrika. [Vol. 13.] Verlag Gustav Fischer, Jena, 247-282.

Kraepelin K (1909) Naturhistorisches Museum, Bericht für das Jahr. Mitteilungen aus dem Naturhistorischen Museum, Beiheft zum Jahrbuch der Hamburgischen Wissenschaftlichen Anstalten 26: I-XI.

Kraepelin K (1911) Neue Beiträge zur Systematik der Gliederspinnen. Mitteilungen aus dem Naturhistorischen Museum in Hamburg, Beiheft zum Jahrbuch der Hamburgischen Wissenschaftlichen Anstalten 28: 57-107.

Kraepelin K (1912a) Naturwissenschaftlich-technische Museen. In: Hinneberg P (Ed.) Die Kultur der Gegenwart. [Vol. 2.] Druck und Verlag von BG Teubner, Leipzig, Berlin, 392-409. https://doi. org/10.1007/978-3-663-19508-5_10

Kraepelin K (1912b) Neue Beitrage zur Systematik der Gliederspinnen, II, Die Subfamilie der Chactinae (Scorpiones). Mitteilungen aus dem Naturhistorischen Museum, Beiheft zum Jahrbuch der Hamburgischen Wissenschaftlichen Anstalten 29: 43-88.

Kraepelin K (1913a) Die Beziehungen der Tiere zueinander und zur Pflanzenwelt Natur und Geisteswelt. [Vol. 426/427.] Verlag BG Teubner, Berlin, 120 pp.

Kraepelin K (1913b) Neue Beiträge zur Systematik der Gliederspinnen, III, A, Bemerkungen zur Skorpionenfauna Indiens, B, Die Skorpione, Pedipalpen und Solifugen Deutsch-Ost-Afrikas. Mitteilungen aus dem Naturhistorischen Museum in Hamburg 30: 121-196.

Kraepelin K (1914a) Bryozoa. In: Michaelsen W (Ed.) Beiträge zur Kenntnis der Land- und Süßwasserfauna Deutsch-Südwestafrikas, Ergebnisse der Hamburger Deutsch-südwestafrikanischen Studien- reise 1911). L. Friederichsen \& Co., Hamburg, 55-69. https://doi. org/10.1002/mmnd.191419140418

Kraepelin K (1914b) Skorpiones und Solifugae. In: Michaelsen W (Ed.) Beiträge zur Kenntnis der Land- und Süßwasserfauna Deutsch-Südwestafrikas, Ergebnisse der Hamburger Deutsch-südwestafrikanischen Studienreise 1911). L. Friederichsen \& Co., Hamburg, 107-136. https://doi.org/10.1002/mmnd.191419140418

Kraepelin K (1914c) Beitrag zur Kenntniss der Skorpione und Pedipalpen Columbiens. In: Fuhrmann O, Mayor E (Eds) Voyage d'exploration scientifique en Colombie. Memoires de la Société Neuchâteloise des Sciences Naturelles 5: 15-28.

Kraepelin K (1914d) Die Skorpione und Pedipalpen von Neu-Caledonien und den benachbarten Inselgruppen In: Sarasin F, Roux J (Eds) Nova Caledonia, Zoologie. [Vol. 1.] C.W. Kreidals Verlag, Wiesbaden, 327-337.

Kraepelin K (1916) Scolopendriden und Skorpione. Results of Dr. E. Mjöberg's Swedish scientific expeditions to Australia, 1910-1913. Arkiv för Zoologi 10: 1-43. https://doi.org/10.5962/bhl.part.1497

Kraepelin K (1917) Exkursionsflora für Nord- und Mitteldeutschland. Ein Taschenbuch zum Bestimmen der im Gebiete einheimischen und häufiger kultivierten Gefässpflanzen für Schüler und Laien (8 ed.). Verlag BG Teubner, Leipzig und Berlin, 410 pp.

Kraepelin K (1918) Leitfaden für den zoologischen Unterricht in den unteren und mittleren Klassen der höheren Schulen, Dritter Teil, Der Mensch (7 ed.). Verlag BG Teubner, Leipzig, 81 pp.

Kraepelin K (1921) Leitfaden für den Zoologischen Unterricht, 1, Wirbeltiere. Verlag BG Teubner, Leipzig, 167 pp.

Kraepelin K (1926) Leitfaden für den Zoologischen Unterricht, 1 Teil, Wirbeltiere (2. Auflage). Verlag BG Teubner, Leipzig, 218 pp.

Kraepelin K (1927) Leitfaden für den botanischen Unterricht, Erster Teil, Einführung in die Pflanzenkunde. Verlag BG Teubner, Berlin, 90 pp.

Kraepelin K (1929) Skorpione, Pedipalpen und Solifugen der zweiten Deutschen Zentral-Afrika-Expedition 1910-1911. Abhandlungen aus dem Gebiete der Naturwissenschaften Verein, Hamburg 22: 85-91.

Lamoral BH (1979) The scorpions of Namibia (Arachnida: Scorpionida). Annals of the Natal Museum 23(3): 497-784.

Leipoldt A (2006) Das erste Jahr der Hamburger Südsee-Expedition in Deutsch-Neuguinea (1908-1909). Master thesis, Diplomica Verlag GmbH, Universität Bayreuth, Hamburg, 291 pp.

Lourenço WR (1987) Révision systématique des scorpions du genre Opisthacanthus (Scorpiones, Ischnuridae). Bulletin du Muséum National d'Histoire Naturelle, Paris, $4^{\text {ème }}$ série 9(4): 887-931.

Lourenço WR (1998) Designation of the scorpion subfamily Scorpiopsinae Kraepelin, 1905 as family Scorpiopsidae Kraepelin, 1905 (stat. nov): its generic composition and a description of a new species of Scorpiops from Pakistan (Scorpiones, Scorpiopsidae). Entomologische Mitteilungen aus dem Zoologischen Museum Hamburg 12(157): 245-254.

Lourenço WR (1999) Notes on the scorpions collected during Fuhrmann's expedition to Colombia and described by Kraepelin. Entomologische Mitteilungen aus dem Zoologischen Museum Hamburg 13(161): 123-132.

Lourenço WR (2003) About two new species of liochelid scorpions collected in Western Africa (Scorpiones, Liochelidae). Entomologische Mitteilungen aus dem Zoologischen Museum Hamburg 14(168): 137-148. 
Lourenço WR (2009) Reanalysis of the genus Scorpio Linnaeus 1758 in sub-Saharan Africa and description of one new species from Cameroon (Scorpiones, Scorpionidae). Entomologische Mitteilungen aus dem Zoologischen Museum Hamburg 15(181): 99-113.

Lourenço WR (2011) The genus Hemiscorpius Peters, 1861 (Scorpiones: Hemiscorpiidae) in East Africa, and description of a new species from Somalia. Entomologische Mitteilungen aus dem Zoologischen Museum Hamburg 15(185): 275-285.

Lourenço WR (2014a) A new species of Opisthacanthus Peters, 1861 (Scorpiones: Hormuridae) from the Parc National d'Andohahela, Madagascar. Entomologische Mitteilungen aus dem Zoologischen Museum Hamburg 17(193): 179-191.

Lourenço WR (2014b) Further consideration on the identity and distribution of Pandinus imperator (C.L.Koch, 1841) and description of a new species from Cameroon (Scorpiones: Scorpionidae). Entomologische Mitteilungen aus dem Zoologischen Museum Hamburg 17(192): 139-151.

Lourenço WR, Cloudsey-Thompson JL (2009) A new species of the genus Scorpio Linnaeus 1758 from Sudan (Scorpiones, Scorpionidae). Boletín Sociedad Entomológica Aragonesa 45: 123-126.

Lourenço WR, Goodman S (2009) Description of a new species of Heteroscorpion Birula, 1903 (Scorpiones: Heteroscorpionidae) from "Grande Lavasoa" in extreme southern Madagascar. Entomologische Mitteilungen aus dem Zoologischen Museum Hamburg 15(181): 115-125.

Lourenço WR, Monod L (2000) Description of a new genus and species of scorpion (Bothriuridae) from Brazil. Ekológia (Bratislava) 19(3): $145-152$.

Lourenço WR, Qi J-X (2006) A new species of Scorpiops Peters, 1861 from Afghanistan (Scorpiones, Scorpiopidae). Entomologische Mitteilungen aus dem Zoologischen Museum Hamburg 14(173): 277-286.

Lowe G, Fet V (2000) Family Bothriuridae Simon, 1880. In: Fet V, Sissom, WD, Lowe G, Braunwalder ME (Eds) Catalog of the Scorpions of the World (1758-1998). The New York Entomological Society, New York, 17-53.

Main BY, Harvey MS (1992) Type material of spiders (Chelicerata: Araneae) collected on the Michaelsen and Hartmeyer Expedition of 1905 and lodged in the Western Australian Museum. Record of the Western Australian Museum 15(4): 703-712.

Maury EA (1973) Sobre las especies de Bothriurus descriptas por F. Werner (Scorpiones, Bothriuridae). Neotropica 19(59): 110-112.

Maury EA (1975a) Sobre el dimorfismo sexual de la pinza de los pedipalpos en los escorpiones Bothriuridae. Bulletin du Muséum National d'Histoire Naturelle, $3^{\text {ème }}$ série 305: 765-771.

Maury EA (1975b) Escorpiones y escorpionismo en el Peru-V: Orobothriurus, un nuevo genero de escorpiones altoandino (Bothriuridae). Revista Peruana de Entomologia 18(1): 14-25.

Maury EA (1984) Redescripcion of Bothiurus bocki Kraepelin 1911 (Scorpiones, Bothriuridae). Journal of Arachnology 12: 351-356.

Merton H (1911) Ergebnisse einer Zoologischen Forschungsreise in den südostlichen Molukken (Aru- und Kei-Inseln) im Auftrag der Senckenbergischen Naturforschenden Gesellschaft ausgeführt von Dr. Hugo Merton, Reisebericht. Abhandlungen herausgegeben von der Senckenbergischen Naturforschenden Gesellschaft 33: 1-208.

Michaelsen W, Hartmeyer R (1907) Reisebericht. In: Michaelsen W, Hartmeyer R (Eds) (1907) Die Fauna Südwest-Australiens. Ergeb- nisse der Hamburger Südwest-Australischen Forschungsreise 1905, 1(1). Verlag von Gustav Fischer, Jena, 117 pp. https://doi. org/10.5962/bhl.title.7416

Mjöberg E (1915) Blanc Vildy Djur och Folk i Australian. Albert Bonnier Förlag, Stockholm, 524 pp.

Monro CCA (1937) Prof. J. W. Michaelsen. Nature 140(3538): 308309. https://doi.org/10.1038/140308a0

Monod L (2000). Révision systématique du genre Liocheles (Ischnuridae, Scorpiones). Master thesis, Université de Genève, Geneva, 143 pp.

Monod L (2011a) The Liochelidae Fet \& Bechly, 2001 (Scorpiones) of the Indo-Pacific region, Systematics and biogeography. $\mathrm{PhD}$ thesis, City University of New York, New York, 848 pp.

Monod L (2011b) Taxonomic emendations in the genus Liocheles Sundevall, 1833 (Scorpiones, Liochelidae). Revue Suisse de Zoologie 118(4): 723-758.

Monod L (2015) Systematics of the genus Hormiops Fage, 1933 (Hormuridae, Scorpiones). Revue Suisse de Zoologie 122(2): 247-282.

Monod L, Prendini L (2015) Evidence for Eurogondwana: the roles of dispersal, extinction and vicariance in the evolution and biogeography of Indo-Pacific Hormuridae (Scorpiones: Scorpionoidea). Cladistics 31: 71-111. https://doi.org/10.1111/cla.12067

Monod L, Volschenk ES (2004) Liocheles litodactylus (Scorpiones: Liochelidae): an unusual new Liocheles species from the Australian wet tropics (Queensland). Memoirs of the Queensland Museum 49(2): 675-90.

Morat P (2010) Les botanistes récolteurs en Nouvelle-Calédonie de 1774 à 2005. Adansonia, série 3 32(2): 159-216. https://doi. org/10.5252/a2010n2a1

Musgrave A (1932) Bibliography of Australian Entomology, 1775-1930. Royal Zoological Society of New South Wales, Sydney, 380 pp.

Naumann vC, Niethammer J (1973) Zur Säugetierfauna des afghanischen Pamir und des Wakhan. Bonner Zoologische Beiträge 3: $237-248$

Nissen C (1952) Dr. Friedrich Ohaus (Mainz 5.xii.1864 - 22.x.1946), A bibliography of his entomological papers. Journal of the Society for the Bibliography of Natural History 2: 400-406. https://doi. org/10.3366/jsbnh.1952.2.9.400

Oboussier H, v Maydell GA (1959) Zur Kenntnis des Indischen Goldlangurs. Ergebniss des Deutschen Indien-Expedition 1955-1957 Leitung G. A. Frhr. v. Maydell. Zeitschrift für Morphologie und Ökologie der Tiere 48(1): 102-114. https://doi.org/10.1007/BF00389911

Oboussier H, v. Maydell GA (1960) Zur Kenntnis von Presbytis entellus (Dufresnes 1797). Ergebniss des Deutschen Indien- Expedition 1955-1957 Leitung: G. A. Frhr. v. Maydell. Zoologischer Anzeiger 164: $141-154$.

Ochoa JA, Ojanguren AA, Mattoni CI, Prendini L (2011) Systematic revision of the Andean scorpion genus Orobothirurus Maury, 1976 (Bothriuridae), with discussion of the altitude records for scorpions. Bulletin of the American Museum of Natural History 359: 1-90. https://doi.org/10.1206/359.1

Ojanguren-Affilastro AA, Volschenk ES, Mattoni CI (2018) The identity of Cercophonius himalayensis Lourenço, 1996, and the exclusion of the scorpion family Bothriuridae from the Indian fauna. Journal of Arachnology 46: 473-480. https://doi.org/10.1636/JoA-S-17-076.1

Pässler R (1922) In der Umgebung Coronel's (Chile) beobachtete Vögel. Beschreibung der Nester und Eier der Brutvögel. Journal für Ornithologie 70: 430-482. https://doi.org/10.1007/BF02538208 
Peters W (1861a) Eine neue Untergattung von Skorpionen. Monatsberichte der Königlichen Preussischen Akademie der Wissenschaften zu Berlin, Jahrgang 1861: 426-427.

Peters W (1861b) Ueber eine neue Eintheilung der Skorpione und ueber die von ihm in Mossambique gesammelten Arten von Skorpionen. Monatsberichte der Königlichen Preussischen Akademie der Wissenschaften zu Berlin, Jahrgang 1861: 507-516.

Peters W (1874) Ueber einige neue Reptilien (Lacerta, Eremias, Diploglossus, Euprepes, Lygosoma, Sepsina, Ablepharus, Simotes, Onychocephalus). Monatsberichte der Königlichen Preussische Akademie der Wissenschaften zu Berlin, Jahrgang 1874: 368-377.

Pocock RI (1892) Descriptions of two new genera of scorpions, with notes upon some species of Palamnaeus. Annals and Magazine of Natural History 8: 38-49. https://doi.org/10.1080/00222939208677269

Pocock RI (1896) On the scorpions, centipedes, and millipedes obtained by Dr. Gregory on his expedition to Mount Kenia, East Africa. Annals and Magazine of Natural History 17(102): 425-444. https://doi. org/10.1080/00222939608680394

Pocock RI (1897a) Report upon the Scorpiones and Pedipalpi obtained on the Lower Amazons by Messrs. E. E. Austen and F. Pickard Cambridge during the trip of Mr. Siemens's Steamship 'Faraday'. Annals and Magazine of Natural History 14(112): 357-368. https://doi. org/10.1080/00222939708680549

Pocock RI (1897b) Descriptions of some new species of scorpions from India. Journal of the Bombay Natural History Society 11: 102-117.

Pocock RI (1900) Report upon a small collection of scorpions and centipedes sent by Mr. Edgar Thurston, of the Government Central Museum. Annals and Magazine of Natural History 5: 236-250. [pl. XII] https://doi.org/10.1080/00222939009460821

Prendini L (2001) A review of synonyms and subspecies in the genus Opistophthalmus C. L. Koch (Scorpiones: Scorpionidae). African Entomology 9(1): 17-48.

Prendini L (2016) Redefinition and systematic revision of the East African scorpion genus Pandinoides (Scorpiones: Scorpionidae) with critique of the taxonomy of Pandinus, sensu lato. Bulletin of the American Museum of Natural History 407: 1-66. https://doi. org/10.1206/0003-0090-407.1.1

Purcell WF (1898) Description of new South African scorpions in the collection of the South African Museum. Annals of South African Museum 1: 1-32. https://doi.org/10.5962/bhl.part.13904

Purcell WF (1899) On the species of Opisthophthalmus in the collection of the South African Museum, with description of some new forms. Annals of South African Museum 1: 131-180. https://doi. org/10.5962/bhl.part.13902

Roux J (1910). Deux archipels voisins de la Nouvelle-Guinée. Iles Arou et Kei. Récit d'une exploration scientifique. Le Globe 49: 1-38. https://doi.org/10.3406/globe.1910.5143

Santibáñez-López CE, González-Santillán E, Monod L, Sharma PP (2019) Phylogenomics facilitates stable scorpion systematics: Reassessing the relationships of Vaejovidae and a new high-level classification of Scorpiones (Arachnida). Molecular Phylogenetics and Evolution 135: 22-30. https://doi.org/10.1016/j. ympev.2019.02.021

Sarasin F (1931) Aus den Tropen. Reiseerinnerungen aus Ceylon, Celebes und Neu-Caledonien. Helbing \& Lichtenhahn, Basel, 194 pp.

Schalgintweit H, Schlagintweit A, Schlagintweit R (1861) Results of a scientific mission to India and High Asia, undertaken between the years 1854 and 1857, by the order of the court of directors of the Honorable East India Company. [Volume 1.] FA Brockhaus, Leipzig/ Trübner \& Co, London, 494 pp.

Schmid F (1958) Contribution à l'etude des trichopteres néotropicaux, III. Mitteilungen aus dem Museum für Naturkunde in Berlin 34: 183-217. https://doi.org/10.1002/mmnz.19580340110

Schuberg A (1880) Carl Semper. In: Bergh R (Ed.) Reisen im Archipel der Philippinen von Dr. C. Semper, Zweiter Theil, Wissenschaftliche Resultate, Band 2, Supplemente, Malacologische Untersuchungen von Dr. Rud Bergh, Nudibranchien. CW Kreisel's Verlag. Wiesbaden, 7-21.

Schultze L (1907) Aus Namaland und Kalahari. Bericht an die Kgl. Preuss. Akademie der Wissenschaftlichen zu Berlin über eine Forschungsreise in Westlichen und zentralen Südafrika, ausgeführt in den Jahren 1903-1905. Verlag von Gustav Fischer, Jena, 752 pp.

Schultze LS (1908) Einleitung. In: Schultze L (Ed.) Zoologische und Anthropologische Ergebnisse einer Forschungsreise im Westlichen und Zentralen Südafrika ausgeführt in den Jahren 1903-1905 mit Unterstützung der Kgl. Preussischen Akademie der Wissenschaften zu Berlin, 1. Verlag Von Gustav Fischer, Jena, v-viii.

Sherlock E, Berridge L (2012) History of the earthworm collections at the Natural History Museum, London (Oligochaeta). Advances of the $5^{\text {th }}$ International Oligochaeta Taxonomy Meeting. Zoology in the Middle East, Supplementum 4: 177-187. https://doi.org/10.1080/09 397140.2012.10649001

Simon E (1872) Arachnides de Syrie rapportés par M. Piochard de la Brulerie (Scorpions et Galéodes). Annales de la Société Entomologique de France 2: 245-266.

Simon E (1874) Etudes arachnologiques, VI, Description d'un scorpion appartenant au genre Buthus Leach. Annales de la Société Entomologique de France 4: 280-282.

Simon E (1876) Etude sur les arachnides du Congo (2ème article). Bulletin de la Société Zoologique de France 1: 216-224.

Simon E (1877a) Etudes arachnologiques, $5^{\text {eme }}$ mémoire (1), IX, Arachnides receuillis aux îles Philippines par MM. G.-A. Baer et Laglaise. Annales de la Société Entomologique de France 7: 54-96.

Simon E (1877b) Etudes arachnologiques, $6^{\text {ème }}$ mémoire (1), X, Arachnides nouveaux ou peu connus. Annales de la Société Entomologique de France 7: 225-242.

Simon E (1878a) Etudes arachnologiques, $7^{\text {mè }}$ mémoire (1), XIII, Description de deux espèces de scorpions. Annales de la Société Entomologique de France 8: 158-160.

Simon E (1878b) Etudes arachnologiques, $9^{\text {ème }}$ mémoire (1), XV, Description de deux nouveaux genres de l'ordre des scorpions. Annales de la Société Entomologique de France 8: 399-400.

Simon E (1879) Scorpiones. In: Simon E (Ed.) Les arachnides de France, 7. Librario Encyclop., Paris, 79-115.

Simon E (1880b) Etudes arachnologiques, $12^{2 \mathrm{me}}$ mémoire (1), XVIII, Descriptions de genres et espèces de l'ordre des scorpiones. Annales de la Société Entomologique de France 10: 377-402.

Simon E (1885) Matériaux pour servir à la faune arachnologique de l'Asie Méridionale. Bulletin de la Société Zoologique de France 10: $1-39$.

Simon E (1887) Etudes arachnologiques, $20^{\text {ème }}$ mémoire (1), XXVIII, Arachnides receuillis dans le sud de l'Afrique par M. le docteur Hans Schinz. Annales de la Société Entomologique de France 7: 369-384. 
Simon E (1908) Araneae, I İe partie. In: Michaelsen W, Hartmeyer R (Eds) Die Fauna Sudwest-Australiens, 1. Verlag von Gustav Fischer, Jena, 359-446.

Simon E (1909) Spiders, $2^{\text {ème }}$ partie. In: Michaelsen W, Hartmeyer R (Eds) Die Fauna Sudwest-Australiens, 2. Verlag von Gustav Fischer, Jena, 155-212.

Sissom WD (2000) Family Chactidae Pocock, 1893. In: Fet V, Sissom WD, Lowe G, Braunwalder ME (Eds) Catalog of the Scorpions of the World (1758-1998). The New York Entomological Society, New York, 286-322.

Soleglad ME, Ayrey RF, Graham MR, Fet V (2017) Catalinia, a new scorpion genus from southern California, USA and northern Baja California, Mexico (Scorpiones: Vaejovidae). Euscorpius 251: 1-64. https://doi.org/10.18590/euscorpius.2017.vol2017.iss251.1

Strube H (2009) Friedrich Ohaus (1864-1946). Mainzer Naturwissenschaftliches Archiv 47: 145-151.

Thilenius G (1914) Ergebnisse der Südsee-Expedition 1908-10. I. Allgemeines. Verlag L. Friederichsen, Hamburg 1927.

Weaver JS, Nimmo AP (1999) Fernand Schmid. Braueria 26: 7-18.
Weidner F (1959) Die Entomologischen Sammlungen des Zoologischen Staatsinstituts und Zoologischen Museums Hamburg, I, Teil, Parathropoda und Chelicerata I. Mitteilungen aus dem Hamburgischen Zoologischen Museum und Institut 54(49): 89-142.

Werner F (1936) Neu-Eingänge von Skorpionen im Zoologischen Museum in Hamburg. Festschrift zum 60. Geburstag von Professor Dr. Embrik Strand 2: 171-193.

Werner F (1939) Neu-Eingänge von Skorpionen im Zoologischen Museum in Hamburg. II. Teil. Festschrift zum 60. Geburtstag von Professor Embrik Strand 5: 351-360.

Winkler H (1920) Verbreitung und Ursache der Parthenogenesis im Pflanzen- und Tierreiche. Verlag Fischer, Jena, 229 pp. https://doi. org/10.5962/bhl.title.1460

Winkler H (1927a) Kurzer Bericht über den Verlauf meiner Reise in Central-Borneo. Mitteilungen aus dem Institut für Allgemeine Botanik in Hamburg 7: 3-7.

Winkler H (1927b) Über eine Rafflesia aus ZentralBorneo. Zeitschrift für wissenschaftliche Biologie, Abteilung E, Planta 4: 1-97. https:// doi.org/10.1007/BF01911186

\section{Appendix 1}

Alphabetical list of taxon names treated in the catalogue.

adustus (VALID) > Opistophthalmus adustus Kraepelin, 1908 [Scorpionidae]

aequispinnus (JUNIOR SYNONYM) > Opisthacanthus (Nepabellus) diremptus (Karsch, 1879) [Hormuridae]

afghanus (VALID) > Scorpiops afghanus Lourenço \& Qi, 2006 [Scorpiopidae]

affinis (JUNIOR SYNONYM) > Scorpiops hardwickii (Gervais, 1843) [Scorpiopidae]

amazonicus (VALID) > Teuthraustes amazonicus (Simon, 1880) [Chactidae]

andohahela (VALID) > Opisthacanthus (Monodopisthacanthus) andohahela Lourenço, 2014 [Hormuridae]

bicolor (JUNIOR SYNONYM) > Urodacus novaehollandiae Peters, 1861 [Urodacidae]

bocki (VALID) > Bothriurus bocki Kraepelin, 1911 [Bothriuridae]

boholiensis (VALID) > Hormurus boholiensis Kraepelin, 1914 [Hormuridae]

burmeisteri (VALID) > Bothriurus burmeisteri Kraepelin, 1894 [Bothriuridae]

asper (VALID) > Opisthacanthus (Nepabellus) asper (Peters, 1861) [Hormuridae]

brevidigitatus (JUNIOR SYNONYM) > Liocheles australasiae (Sundevall, 1775) [Hormuridae]

calvus (JUNIOR SYNONYM) > Opistophthalmus latimanus C. L. Koch, 1841 [Scorpionidae]

camerounensis (JUNIOR SYNONYM) > Pandinus imperator (C. L. Koch, 1841) [Scorpionidae]

catharinae (JUNIOR SYNONYM) > Bothriurus signatus Pocock, 1893 [Bothriuridae]

caudicula (JUNIOR SYNONYM) > Hormurus waigiensis (Gervais, 1843) [Hormuridae]

crassimanus (VALID) > Opistophthalmus crassimanus Purcell, 1899 [Scorpionidae]

curvidigitus (VALID) > Orobothriurus curvidigitus (Kraepelin, 1911) [Bothriuridae]

dastychi (VALID) > Scorpiops dastychi Kovařík , 1999 [Scorpiopidae]

exsul (VALID) > Chactas exsul (Werner, 1939) [Chactidae]

feti (VALID) > Scorpiops feti Kovařík, 2000 [Scorpiopidae]

fischeri (JUNIOR SYNONYM) > Opisthacanthus (Nepabellus) rugiceps Pocock, 1897 [Hormuridae]

flavidus (VALID) > Bothriurus flavidus Kraepelin, 1911 [Bothriuridae]

fossor (VALID) > Opistophthalmus fossor Purcell, 1898 [Scorpionidae]

fossor (JUNIOR SYNONYM) > Urodacus yaschenkoi (Birula, 1903) [Urodacidae]

fuchsii (JUNIOR SYNONYM) > Chactas vanbenedenii (Gervais, 1843) [Chactidae]

fuscipes (VALID) > Opistophthalmus fuscipes Purcell, 1898 [Scorpionidae]

glaber (VALID) > Cheloctonus glaber Kraepelin, 1896 [Hormuridae]

granicauda (VALID) > Opistophthalmus granicauda Purcell, 1898 [Scorpionidae]

granulosus (VALID) > Cercophonius granulosus Kraepelin, 1908 [Bothriuridae]

gregorii (VALID) > Pandinurus gregoryi (Pocock, 1896) [Scorpionidae]

hartmeyeri (VALID) > Urodacus hartmeyeri Kraepelin, 1908 [Urodacidae]

hasethi (VALID) > Didymocentrus hasethi (Kraepelin, 1896) [Diplocentridae] 
himalayensis (JUNIOR SYNONYM) > Phoniocercus sanmartini Cekalovic, 1968 [Bothriuridae] intercedens (VALID) > Opistophthalmus intercedens Kraepelin, 1908 [Scorpionidae] intermedius (JUNIOR SYNONYM) > Chactas lepturus Thorell, 1876 [Chactidae] kaii (VALID) > Heteroscorpion kaii Lourenço \& Goodman, 2009 [Heteroscorpionidae] karrooensis (VALID) > Opistophthalmus karrooensis Purcell, 1898 [Scorpionidae] keilandsi (VALID) > Opistophthalmus keilandsi Hewitt, 1914 [Scorpionidae] keyensis (JUNIOR SYNONYM) > Hormurus karschii (Keyserling, 1885) [Hormuridae] kraepelini (VALID) > Scorpiops kraepelini Lourenço, 1998 [Scorpiopidae] laeviceps (VALID) > Iomachus laeviceps Pocock, 1890 [Hormuridae] leipoldti (VALID) > Opistophthalmus leipoldti Purcell, 1898 [Scorpionidae] lepturus (VALID) > Hemiscorpius lepturus Peters, 1861 [Hemiscorpiidae] maculatus (VALID) > Bothriurus maculatus Kraepelin, 1911 [Bothriuridae] madagascariensis (VALID) > Opisthacanthus (Monodopisthacanthus) madagascariensis Kraepelin, 1894 [Hormuridae] maindroni (VALID) > Hemiscorpius maindroni Kraepelin,1900 [Hemiscorpiidae] major (VALID) > Chactas major Kraepelin, 1912 [Chactidae] michaelseni (VALID) > Cercophonius michaelseni Kraepelin,1908 [Bothriuridae] minimus (VALID) > Catalinia minima (Kraepelin, 1911) [Vaejovoidea] minor (JUNIOR SYNONYM) > Opisthacanthus (Nepabellus) validus Thorell, 1876 [Hormuridae] neocaledonicus (VALID) > Hormurus neocaledonicus (Simon, 1877) [Hormuridae] politus (JUNIOR SYNONYM) > Brachistosternus ehrenbergii (Gervais, 1841) [Bothriuridae] obscurus (JUNIOR SYNONYM) > Opisthacanthus (Nepabellus) capensis Thorell, 1876 [Hormuridae] occidentalis (VALID) > Iomachus politus occidentalis Lourenço, 2003 [Hormuridae] occidentalis (VALID) $>$ Scorpio occidentalis Werner, 1936 [Scorpionidae] ochripes (JUNIOR SYNONYM) > Opisthacanthus (Nepabellus) validus Thorell, 1876 [Hormuridae] ohausi (VALID) > Teuthraustes ohausi Kraepelin, 1912 [Chactidae] opisthacanthoides (VALID) > Heteroscorpion opisthacanthoides (Kraepelin, 1896) [Heteroscorpionidae] ozendai (VALID) > Chactas ozendai Lourenço, 1999 [Chactidae] paessleri (VALID) > Orobothriurus paessleri (Kraepelin, 1911) [Bothriuridae] pallidus (VALID) > Opisthacanthus (Nepabellus) africanus pallidus Lourenço, 2003 [Hormuridae] pallidus (VALID) > Pandinurus pallidus (Kraepelin, 1894) [Scorpionidae] pantanalensis (VALID) > Brazilobothriurus pantanalensis Lourenço \& Monod, 2000 [Bothriuridae] parvulus (VALID) > Broteochactas parvulus Pocock, 1897 [Chactidae] pauliani (VALID) > Palaeocheloctonus pauliani Lourenço, 1996 [Hormuridae] papuanus (VALID) > Hormurus papuanus Kraepelin, 1914 [Hormuridae] phipsonii (VALID) > Heterometrus phipsonii (Pocock,1893) [Scorpionidae] pictus (VALID) > Opistophthalmus pictus Kraepelin, 1894 [Scorpionidae] pilosus (JUNIOR SYNONYM) > Opistophthalmus flavescens Purcell, 1898 [Scorpionidae] sarasini (JUNIOR SYNONYM) > Hormurus neocaledonicus (Simon, 1877) [Hormuridae] reticulatus (VALID) > Chactas reticulatus Kraepelin, 1912 [Chactidae] savanicola (VALID) > Scorpio savanicola Lourenço, 2009 [Scorpionidae] schultzei (VALID) > Opistophthalmus schultzei Kraepelin, 1908 [Scorpionidae] setosus (VALID) > Chactas setosus Kraepelin, 1912 [Chactidae] somalicus (VALID) > Hemiscorpius somalicus Lourenço, 2011 [Hemiscorpiidae] sulcatus (VALID) > Cercophonius sulcatus Kraepelin, 1908 [Bothriuridae] thorellii (JUNIOR SYNONYM) > Heterometrus bengalensis (C. L. Koch, 1841) [Scorpionidae] titschacki (VALID) > Centromachetes titschacki (Werner,1939) [Bothriuridae] transvaalicus (JUNIOR SYNONYM) > Opisthacanthus (Nepabellus) validus Thorell, 1876 [Hormuridae] trivittatus (VALID) > Bothriurus trivittatus Werner, 1939 [Bothriuridae] troglodytes (VALID) > Hadogenes troglodytes (Peters, 1861) [Hormuridae] ubicki (VALID) > Heterometrus ubicki Kovařík, 2004 [Scorpionidae] undulatus (JUNIOR SYNONYM) > Opistophthalmus schultzei Kraepelin, 1908 [Scorpionidae] wittii (VALID) > Teuthraustes witti (Kraepelin, 1896) [Chactidae] yemenensis (VALID) > Scorpio yemensis Werner, 1936 [Scorpionidae] 